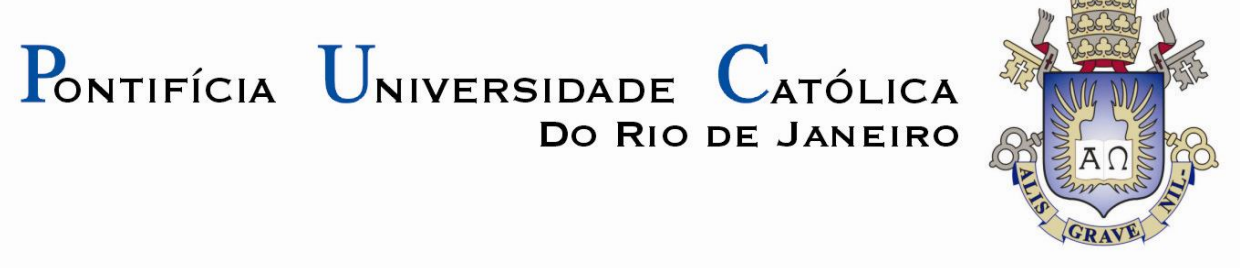

Naira da Costa Muylaert Lima

\title{
Educação e Desigualdades sociais: suas relações no estado do Espírito Santo
}

Tese de Doutorado

Tese apresentada ao Programa de PósGraduação em Educação do Departamento de Educação da PUC-Rio como parte dos requisitos parciais para obtenção do título de Doutor em Educação.

Orientadora: Prof ${ }^{\mathrm{a}}$ Alicia Maria Catalano de Bonamino 


\section{Pontifícia Universidade Católica DO RIO DE JANEIRO}

Naira da Costa Muylaert Lima

\section{Educação e Desigualdades sociais: suas relações no estado do Espírito Santo}

Tese apresentada como requisito parcial para obtenção do título de Doutor pelo Programa de PósGraduação em Educação do Departamento de Educação do Centro de Teologia e Ciências Humanas da PUC-Rio. Aprovada pela Comissão Examinadora abaixo assinada.

Prof ${ }^{\mathrm{a}}$ Alicia Maria Catalano de Bonamino Orientadora

Departamento de Educação - PUC-Rio

Prof $^{\mathrm{a}}$ Cynthia Paes de Carvalho Departamento de Educação - PUC-Rio

Prof $^{\mathrm{a}}$ Sandra Maria Zákia Lian Sousa USP

Prof ${ }^{\circ}$ Antonio Augusto Gomes Batista CENPEC

Prof $^{\circ}$ Luis Antônio Fajardo Pontes

CAEd/UFJF

Prof ${ }^{\mathrm{a}}$ Denise Berruezo Portinari Coordenadora Setorial do Centro de Teologia e Ciências Humanas

PUC-Rio

Rio de Janeiro, 15 de abril de 2016 
Todos os direitos reservados. É proibida a reprodução total ou parcial do trabalho sem a autorização da universidade, da autora e do orientador.

\section{Naira da Costa Muylaert Lima}

Graduou-se em Pedagogia pela Universidade Federal do Estado do Rio de Janeiro (UNIRIO) em 2008. Em 2010 cursou o Mestrado em Educação pela Pontifícia Universidade Católica do Rio de Janeiro (PUC-Rio). É pesquisadora na área de avaliação da educação do Laboratório de Avaliação da Educação (LAED) da PUCRio.

Ficha Catalográfica

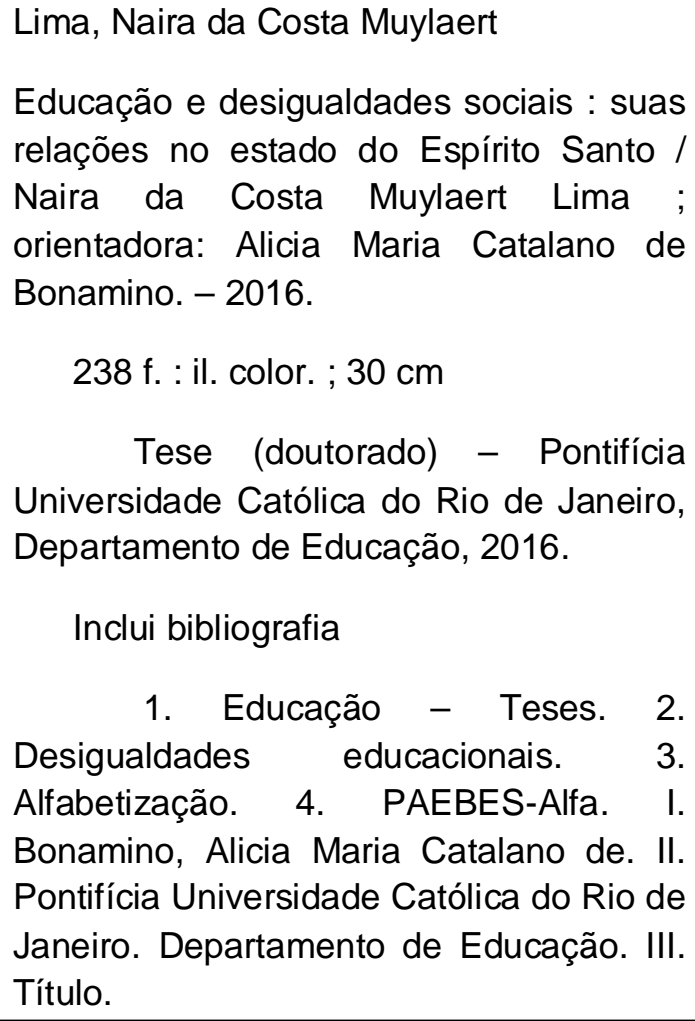

CDD: 370 
Aos meus pais Hilário e Nelzi e à minha irmã Teresa pelo amor incondicional. 


\section{Agradecimentos}

À minha querida amiga e orientadora Alicia Bonamino, pela sabedoria, paciência, carinho e dedicação com que conduziu a realização desse trabalho e por todoo empenho em me ajudar a compreender e articular os conceitos teóricos aos dados estatísticos. Muito obrigada por percorrer esse caminho junto comigo e por todo o aprendizado que me proporcionou.

À CAPES, ao CNPq e à PUC-Rio, pelos auxílios concedidos, sem os quais este trabalho não poderia ter sido realizado.

À Secretaria Estadual de Educação do Espírito Santo pela autorização para acesso dos dados e instrumentos de avaliação do PAEBES-Alfa, sem a qual esta trabalho não teria sido possível.

À Secretaria Municipal de Educação de Cariacica e à Secreatria Municipal de Educação de Serra pela autorização para a entrada nas escolas de forma a viabilizar a investigação qualitativa da pesquisa.

Ao professor Marcel Crahay, por quem tive a honra de ser recebida, na Université de Genève, em meu estágio de doutorado no exterior, pelos debates e contribuições para meu amadurecimento nas discussões acerca da desigualdade educacional.

Ao professor George Felouzis, da Université de Genève, por ter me acolhido em suas aulas sobre métodos quantitativos, e com o qual pude aprimorar meus conhecimentos no manuseio do software estatístico SPSS.

Ao grupo de pesquisa DAIS - Développement, Apprentissage et Intervention en Situations Scolaires, da Université de Genève, do qual pude participar durante meu estágio de doutorado e que trouxeram importantes contribuições para o desenho da pesquisa.

Ao professor Luis Antonio Fajardo Pontes pelo apoio, colaboração e explicações acerca dos procedimentos estatísticos, fundamentais para a realização deste trabalho. 
Ao Wellington Silva, coordenador a Coordenação de Medidas Educacionais do Centro de Políticas Públicas e Avaliação da Educação - CAEd e colega do curso de doutorado em Educação da PUC-Rio, pelo apoio e colaboração nas análises dos dados estatísticos e pelas enriquecedoras discussões e reflexões acerca da pesquisa.

Ao Centro de Políticas Públicas e Avaliação da Educação - CAEd, pela colaboração com a análise dos dados estatísticos, em especial à equipe.

Ao Wellington Silva e Josiane Toledo, pela amizade, carinho e acolhimento durante minhas numerosas e longas estadias em Juiz de Fora/MG.

Aos colegas do grupo de pesquisa Laboratório da Avaliação da Educação LAEd, do qual faço parte e com o qual pude contar com o total apoio para a realização da pesquisa.

Aos meus amigos e colegas da PUC-Rio.

Ao Departamento de Educação da PUC-Rio, pela excelência dos cursos que oferece, proporcionando aos alunos uma sólida formação acadêmica.

Aos meus amigos queridos que me acompanharam nessa trajetória, sempre vibrando por cada passo conquistado.

À minha família, que nos momentos mais difíceis seguraram minha mão e me orientaram com a firmeza e a doçura do amor. 


\section{Resumo}

Lima, Naira da Costa Muylaert; Bonamino, Alicia Maria Catalano de. Educação e desigualdades sociais: suas relações no estado do Espírito Santo. Rio de Janeiro, 2016. 238p. Tese de Doutorado - Departamento de Educação, Pontifícia Universidade católica do Rio de Janeiro.

Este trabalho busca contribuir para o debate acerca do tema das desigualdades educacionais, por meio dos dados do PAEBES-Alfa - avaliação longitudinal da alfabetização do estado do Espírito Santo. Utilizando uma metodologia "quali-quanti", o estudo teve como objetivo investigar as desigualdades de oportunidades, de tratamento e, principalmente, de conhecimento. As desigualdades de oportunidades e de tratamento foram observadas numa perspectiva macroanalítica e contextual, nas diferentes etapas da educação básica, no Brasil e nos estados da região Sudeste,segundo diferentes característicasdos alunos, , como raça/cor e renda familiar per capita, e das escolas, como localidade e região. A desigualdade de conhecimento foi investigada de forma longitudinal por meio dos dados referentes ao percentual de acerto dos alunos nos testes da avaliação do PAEBES-Alfa. Por fim, por meio de uma abordagem qualitativa, a pesquisa observou quatro escolas e 14 salas de aula, e realizou entrevistas com seus diretores, pedagogos e professores, com a finalidade de melhor compreender os dados quantitativos apresentados pelas avaliações. São basicamente dois os principais resultados obtidos com a aplicação do modelo de análise baseado no percentual de acerto dos itens difíceis dos testes de Leitura do PAEBES-Alfa, aplicados aos alunos nos três primeiros anos do Ensino Fundamental público do Estado do Espírito Santo. Por um lado este modelo, após o controle do nível socieoconômico dos alunos, permitiu constatar que, no caso da evolução geral da aprendizagem no período correspondente ao ciclo de alfabetização, as diferenças de desempenho entre as turmas diminuem entre o $1^{\circ}$ e o $3^{\circ}$ ano. Por outro lado, permitiu identificar aspectos do currículo que se associam às semelhanças e diferenças de resultados observadas entre as turmas de alto e baixo desempenho, refletindo uma desigualdade de conhecimento decorrente da falta de ensino e/ou de consolidação de habilidades básicas de leitura no período da alfabetização. A adoção de um desenho metodológico misto, pelo qual foram investigadas também qualitativamente quatro dessas escolas e 
suas 14 turmas do $3^{\circ}$ ano do Ensino Fundamental, contibiuiu para o entendimento das práticas pedagógicas e escolares que favorecem ou não o crescimentos da aprendizagem dos alunos com maiior ou menor qualidade e equidade.

\section{Palavras-chave}

Desigualdades educacionais; Alfabetização; PAEBES-Alfa. 


\section{Resumée}

Lima, Naira da Costa Muylaert; Bonamino, Alicia Maria Catalano de (Conseiller). Éducation et inégalités sociales: leurs relations dans l'état d'Espirito Santo. Rio de Janeiro, 2016. 238p. Thèse de doctorat Departamento de Educação, Pontifícia Universidade Católica do Rio de Janeiro.

Ce travail vise à contribuer au débat sur la question des inégalités scolaires, en utilisant les données de l'évaluation longitudinale d'alphabétisation (PAEBES-Alfa) dans l'état de Espírito Santo. En utilisant une méthodologie "qualitative et quantitative", l'étude visait à examiner les inégalités des chances, traitement et connaissance. L'inégalité des chances et de traitement ont été observés dans les différentes étapes de l'éducation de base au Brésil et dans les États de la région du Sud-Est, selon différents caractéristiques des étudiants, comme la race, par exemple. L'inégalité des savoirs a été étudiée longitudinalement à travers les données sur le pourcentage correct des questions des tests du PAEBES-Alfa. Enfin, grâce à une approche qualitative, la recherche a observé quatre écoles et 14 classes et a mené des entrevues avec les directeurs, les enseignants et les éducateurs, afin de mieux comprendre les données quantitatives présentées par des évaluations. Sont essentiellement deux les principaux résultats obtenus à partir de l'application du modèle analyse basé sur le pourcentage de succès des éléments difficiles de lecture du PAEBES-Alfa, appliqué aux étudiants dans les trois premières années de l'école élémentaire publique de l'Etat du Espírito Santo. D'une part ce modèle, après contrôle du niveau socioéconomique des étudiants, a montré que, dans le période correspondant au cycle de l'alphabétisation, les différences de performances entre les classes diminuent entre la 1ère et la 3e année. D'autre part, le travail a identifié les aspects du programme d'études qui sont associés à des similitudes et des différences de résultats observés entre les classes de rendement élevé et faible, ce qui reflète l'inégalité des connaissances. L'adoption d'une conception méthodologique mixte, pour lesquels ils ont été étudiés qualitativement quatre de ces écoles et leurs 14 classes de la troisième année de l'école élémentaire, ont contribué pour comprendre les pratiques pédagogiques et scolaires qui favorisent ou non la qualité et l'équité d'apprentissage. 


\section{Mot-clé}

Inégalités éducatives; L'alphabétisation; PAEBES-Alpha. 


\section{Sumário}

INTRODUÇÃO 18

DESIGUALDADE SOCIAL E EDUCAÇÃO 21

1.1 Justiça como equidade $\quad 21$

1.2 Equidade ou igualdade? 24

1.3 As três formas de justiça na educação: igualdade de
oportunidade, de tratamento e de conhecimento

1.3.1 Igualdade de oportunidades 28

1.3.2 Igualdade de tratamento 32

1.3.3lgualdade de conhecimento 35

1.3.4 Ações pedagógicas de discriminações negativas, positivas e neutras 41

1.4 Categorias de análise da igualdade $\quad 45$

$1.5 \mathrm{O}$ estudo da desigualdade no Brasil $\quad 47$

METODOLOGIA 58

2.1 Sobre a alfabetização no Brasil e o PAEBES-Alfa 59

2.2Objetivo, questões de estudo e metodologia 65

AS DESIGUALDADES NO SISTEMA EDUCACIONAL BRASILEIRO: nível macro de análise $\quad 70$

3.1 O Brasil e a desigualdade de oportunidades educacionais............72

3.1.1 A desigualdade de acesso 72

3.1.2 A desigualdade da qualidade educacional 79

$\begin{array}{ll}\text { Aprendizado } & 79\end{array}$

Fluxo escolar $\quad 82$

3.2 A região Sudeste e a desigualdade de oportunidades educacionais $\quad 85$

3.2.1 A desigualdade de acesso da região Sudeste 85

3.2.2 A desigualdade da qualidade educacional da região Sudeste 91

$\begin{array}{ll}\text { Aprendizado } & 91\end{array}$

Fluxo escolar 94

A DESIGUALDADE DE CONHECIMENTO: nível meso de análise 97

4.1 A análise dos percentuais de acerto dos itens nos testes 101

1ำANO DO ENSINO FUNDAMENTAL 113 
3 ANO DO ENSINO FUNDAMENTAL

INVESTIGANDO AS ESCOLAS E AS TURMAS: nível micro de análise

5.1 Sobre a seleção das escolas

5.1.1 A escolha das escolas investigadas

5.2 A investigação quali-quanti

5.2.1 Os dados de desempenho médio das escolas e das turmas

5.2.2 As características escolares

160

CONSIDERAÇÕES FINAIS

Referências Bibliográficas

ANEXOS

ANEXO 1

ANEXO 2

201

ANEXO 3

215

ANEXO 4

216

ANEXO 5

218

ANEXO 6

227 


\section{Lista de quadros}

Quadro 1: Igualdade de Tratamento 34

Quadro 2: Tempo em minutos destinado a cada categoria 40

Quadro 3: Síntese de princípios e características das concepções de justiça

Quadro 4: Conceitos de desigualdade, possíveis indicadores e variáveis do estudo

Quadro 5: Tipo de desigualdade, indicadores e variáveis

56

Quadro 6: Média do desempenho por domínio da alfabetização -

PAEBES-Alfa

Quadro 7: Categorização das escolas em

homogêneas/heterogêneas

Quadro 8: Percentual de acerto e variação dos itens difíceis por nível de desempenho - $1^{\circ}$ ano do EF

Quadro 9: Percentual de acerto e variação dos itens difíceis

por nível de desempenho - $3^{\circ}$ ano do EF

Quadro 10: Habilidades com baixo percentual de acerto nos dois anos escolares

Quadro 11: Descrição das características das escolas nos clusters

Quadro 12: Os dois tipos de escolas

133

Quadro 13: Perfis das escolas

133

Quadro 14: Número de escolas por município 


\section{Lista de tabelas}

Tabela 1: Nível de desempenho do 50 ano do Ensino Fundamental para Língua Portuguesa (Leitura) - ANEB e ANRESC/Prova Brasil

Tabela 2: Níveis de desempenho do 5 ano do Esnino Fundamental para Matemática - ANEB e ANRESC/Prova Brasil

Tabela 3: Porcentagem de crianças de 0 a 3 anos na escola Todas as redes

Tabela 4: Porcentagem de crianças de 4 a 5 anos na escola Todas as redes

Tabela 5: Porcentagem de crianças de 6 a 14 anos na escola Taxa de matrícula líquida - Todas as redes

Tabela 6: Porcentagem de crianças de 15 a 17 anos na escola -

Taxa de matrícula líquida - Todas as redes

Tabela 7: Porcentagem de crianças do $3^{\circ}$ ano do Ensino Fundamental por nível de proficiência em Leitura (2014) - ANA

Tabela 8: Porcentagem de crianças do $3^{\circ}$ ano do Ensino Fundamental por nível de proficiência em Escrita (2014) - ANA

Tabela 9: Porcentagem de crianças do $3^{\circ}$ ano do Ensino Fundamental por nível de desempenho em Matemática (2014) - ANA

Tabela 10: Taxa de distorção idade-série - Anos Iniciais do Ensino Fundamental - Todas as redes

Tabela 11: Taxa de distorção idade-série - Anos Iniciais do Ensino Fundamental - Rede Pública

Tabela 12: Taxa de distorção idade-série - Anos Iniciais do Ensino Fundamental - Rede Particular

Tabela 13: Porcentagem de crianças de 0 a 3 anos na escola Todas as redes - Região Sudeste

Tabela 14: Porcentagem de crianças de 0 a 3 anos na escola por raça/cor (2013) - Todas as redes - Região Sudeste

Tabela 15: Porcentagem de crianças de 4 a 5 anos na pré-escola Todas as redes - Região Sudeste

Tabela 16: Porcentagem de crianças de 4 a 5 anos na escola por cor/raça (2013) - Todas as redes - Região Sudeste

Tabela 17: Porcentagem de crianças de 6 a 14 anos matriculadas no Ensino Fundamental - Taxa líquida de matrícula - Todas as redes Região Sudeste

Tabela 18: Porcentagem de crianças de 6 a 14 anos matriculadas no Ensino Fundamental por cor/raça - Taxa líquida de matrícula (2013) Todas as redes - Região Sudeste 
Tabela 19: Porcentagem de jovens de 15 a 17 anos matriculados no Ensino Médio - Taxa líquida de matrícula - Todas as redes - Região Sudeste

Tabela 20: Porcentagem de jovens de 15 a 17 anos matriculados no Ensino Médio por cor/raça - Taxa líquida de matrícula (2013) Todas as redes - Região Sudeste

Tabela 21: Porcentagem de crianças do $3^{\circ}$ ano do Ensino

Fundamental por nível de proficiência em Leitura (2014) - Todas as redes - Região Sudeste - ANA

Tabela 22: Porcentagem de crianças do $3^{\circ}$ ano do Ensino

Fundamental por nível de proficiência em Escrita (2014) - Todas as redes - Região Sudeste - ANA

Tabela 23: Porcentagem de crianças do $3^{\circ}$ ano do Ensino

Fundamental por nível de proficiência em Matemática (2014) - Todas

as redes - Região Sudeste - ANA

Tabela 24: Taxa de distorção idade-série - Anos Iniciais do Ensino

Fundamental - Todas as redes - Região Sudeste

Tabela 25: Taxa de distorção idade-série - Anos Iniciais do Ensino Fundamental - Rede Pública - Região Sudeste

Tabela 26: Taxa de distorção idade-série - Anos Iniciais do Ensino Fundamental - Rede Particular - Região Sudeste

Tabela 27: Percentual de matrícula por rede de ensino (2014) -

Espírito Santo

Tabela 28: Distribuição das escolas em quartis

Tabela 29: Escolas que mudaram de quartil

Tabela 30: Distribuição das escolas nos 8 perfis

Tabela 31: Desempenho médio das escolas por avaliação

Tabela 32: Padrões de desempenho das escolas 


\section{Lista de gráficos}

Gráfico 1: Valor agregado pelas escolas - PAEBES-Alfa

Gráfico 2: Correlação entre o percentual de acerto dos itens e sua variação - 1ํ ano do Ensino Fundamental

Gráfico 3: Correlação entre o percentual de acerto dos itens e sua variação - $3^{\circ}$ ano do Ensino Fundamental

Gráfico 4: Correlação entre o percentual de acerto dos itens e seu grau de dificuldade $-1^{\circ}$ ano do Ensino Fundamental

Gráfico 5: Correlação entre o percentual de acerto dos itens e seu grau de dificuldade - 3o ano do Ensino Fundamental

Gráfico 6: Correlação entre a variação do percentual de acerto dos itens e seu grau de dificuldade $-1^{\circ}$ ano do Ensino Fundamental

Gráfico 7: Correlação entre a variação do percentual de acerto dos itens e seu grau de dificuldade $-3^{\circ}$ ano do Ensino Fundamental

Gráfico 8: Percentual de acerto dos itens difíceis por turmas - 10 ano

Gráfico 9: Percentual de acerto dos itens difíceis por turmas - 3ํa ano 123

Gráfico 10: Escola Tulipa - Evolução do desempenho médio em

Português

Gráfico 11: Escola Tulipa - Valor agregado

Gráfico 12: Escola Rosa - Evolução do desempenho médio em

Português

Gráfico 13: Escola Rosa - Valor agregado

Gráfico 14: Escola Lírio - Evolução do desempenho médio em

Português

Gráfico 15: Escola Lírio - Valor agregado

Gráfico 16: Escola Girassol - Evolução do desempenho médio em

Português

Gráfico 17: Escola Girassol -Valor agregado

Gráfico 18: Evolução do desempenho médio em Leitura 144

Gráfico 19: Evolução de desempenho médio em Escrita

Gráfico 20: Evolução do desempenho médio em Leitura por turmas -

Escola Tulipa

Gráfico 21: Evolução do desempenho médio em Escrita por turmas -

Escola Tulipa

Gráfico 22: : Evolução do desempenho médio em Leitura por turma -

Escola Rosa

Gráfico 23: : Evolução do desempenho médio em Escrita por turma -

Escola Rosa

Gráfico 24: Evolução do desempenho médio em Leitura por turma -

Escola Girassol

Gráfico 25: Evolução do desempenho médio em Escrita por turma Escola Girassol 
Gráfico 26: Evolução do desempenho médio em Leitura por turma Escola Lírio

Gráfico 27: Evolução do desempenho médio em Escrita por turma Escola Lírio

\section{Lista de figuras}

Figura 1: Item P64

118

Figura 2: Item P65 


\section{INTRODUÇÃO}

No Brasil, e no campo da sociologia da educação, é cada vez mais recorrente o estudo acerca das relações entre as desigualdades sociais e as desigualdades educacionais. Diversos estudos nessa área de investigação apontam a escola como uma importante instituição capaz de amplificar ou diminuir as desigualdades existentes entre os diferentes grupos sociais.

A discussão sobre as desigualdades de oportunidades educacionais referentes à Educação Básica - obrigatória para os alunos dos 4 aos 17 anos, no contexto brasileiro - ressalta não apenas que o acesso aos diferentes níveis desta etapa educacional ainda não está plenamente garantido mas, principalmente, que sua oferta se dá de forma persistentemente desigual, segundo diferenças de renda, de raça/cor e de gênero dos alunos.

Com a implementação e consolidação dos sistemas de avaliação educacional, os estudos sobre as desigualdades começaram a tratar do tema a partir dos resultados de desempenho, obtidos pela aplicação de testes cognitivos, o que permitiu que o foco das análises começasse a abordar, também, a desigualdade de resultados escolares.

Assim, a partir dos dados das avaliações em larga escala, diversos estudos começaram a ser realizados a fim de averiguar, para além da influência do contexto social sobre o desempenho escolar, os fatores escolares que ajudam a explicar não apenas os resultados obtidos nas avaliações como também a desigualdade desses resultados segundo os diferentes grupos sociais, sistemas educativos e unidades escolares. De um modo geral, esses estudos se ancoram em conceitos de eficácia, justiça, equidade e igualdade de oportunidades, de tratamento e de conhecimento.

Para aprofundar a compreensão desses conceitos e suas abordagens empíricas, foi me dada a oportunidade de participar do Programa de Doutorado Sanduíche no Exterior (PDSE) da Coordenação de Aperfeiçoamento de Pessoal de Nível Superior - CAPES, no qual foi possível realizar um estágio de seis meses na Universidade de Genebra, junto ao professor Marcel Crahay. A realização do estágio garantiu a apropriação dos conceitos que fundamentam diversas 
pesquisasno campo da sociologia da educação, bem como o contato com outras abordagens metodológicas adotadas no estudo desta temática.

Com base nesses conceitos, e utilizando uma metodologia "quali-quanti", esta tese teve o objetivo de investigar as desigualdades de oportunidades, de tratamento e, principalmente, de conhecimento, nas redes públicas de ensino fundamental do Estado de Espírito Santo. Trata-se, mais especificamente, de investigar as desigualdades presentes na educação escolar, utilizando medidas de aprendizado dos alunos do Programa de Avaliação da Educação Básica do Espírito Santo, voltado para a alfabetização (PAEBES-Alfa), para investigar como são produzidas, reproduzidas e geridas, pelas políticas escolares e educacionais, as desigualdades entre as escolas e entre as turmas das escolas. $\mathrm{O}$ PAEBES-Alfa se diferencia das demais avaliações estaduais por apresentar carcaterísticasque fornecem dados mais precisos sobre as redes de ensino, as escolas e os alunos. Além da inclusão de itens de Escrita nas provas aplicadas aos alunos, o PAEBES-Alfa tem um desenho longitudinal, que permite verificar a evolução do aprendizado dos alunos e o valor agregado ao desempenho ao longo dos três primeiros anos, correspondentes ao ciclo de alfabetização.São principalmente estas duas últimas carcaterísticas que justificam a escolhadesta avaliação para a investigação do tema das desigualdades entre as escolas e dentro das escolas nos anos iniciais do ensino fundamental.

A igualdade de oportunidades e de tratamento foi observada numa perspectiva macroanalítica e contextual, tomando como referência as condições de acesso a uma escola de qualidade ofertadas pelas diferentes etapas da Educação Básica, no Brasil e nos estados da região Sudeste, segundo diferentes características dos alunos, como raça/cor e renda familiar per capita, e das escolas, como localidade e região.

O tema da igualdade de conhecimento foi investigada de forma longitudinal, por meio do percentual de acerto dos alunos nos testes da avaliação do PAEBES-Alfa. Esta abordagem permitiu analisar as habilidades de leitura que os alunos estão adquirindo no período referente à alfabetização e, também, a desigualdade dessa aquisição segundo as escolas e suas turmas. Por fim, por meio de uma abordagem qualitativa, a pesquisa observou quatro escolas e 14 salas de 
aula, e realizou entrevistas com diretores, pedagogos e professores, com a finalidade de melhor compreender os resultados quantitativos da psequisa.

Além desta introdução e das considerações finais, este trabalho está organizado em cinco capítulos. O primeiro apresenta a discussão teórica dos conceitos de igualdade de oportunidades, de tratamento e de conhecimento, de forma a fundamentar as categorias de análise do estudo.

O segundo capítulo trata da abordagem metodológica adotada, do objeto do estudo e das principais questões que nortearam a investigação.

O terceiro capítulo aborda a desigualdade educacional no nível macroanalítico, mais especificamente a desigualdade de acesso e de tratamento nas diferentes etapas da Educação Básica, no Brasil e nos estados da região Sudeste.

Com base nos dados do PAEBES-Alfa, o capítulo 4 está fundamentado no conceito de igualdade de conhecimento no nível meso, adotando um modelo que considera os percentuais de acerto dos itens de Leitura e a variação desses percentuais segundo as escolas e as turmas. Esse modelo permitiu verificar as habilidades adquiridas pelos alunos e asdesigualdades presentes na aquisição dessas habilidades.

No capítulo 5, nível micro, é apresentado o estudo desenvolvido em quatro escolas públicas municipais de Cariacica e Serra, para investigar as características escolares e levantar possíveis explicações para as desigualdades de resultados escolares identificadas entre as turmas e entre as escolas. 


\section{DESIGUALDADE SOCIAL E EDUCAÇÃO}

As formas e os processos educacionais relacionados à desigualdade social são objeto de estudo da pesquisa no campo da sociologia da educação evêm apresentando intenso desenvolvimento nos últimos anos, no Brasil. Os dados empíricos produzidos por estudos alinhados a esse campo de estudo apontam para a persistência das desigualdades sociais nas oportunidades de escolarização dos diferentes grupos sociais, mesmo em sistemas educativos democráticos (SILVA, 2003).

De forma mais ou menos explícita, os estudos que buscam investigar as relações entre desigualdades sociais e desigualdades educacionais se ancoram em conceitos de eficácia, justiça, igualdade (de oportunidade, de tratamento e de conhecimento) e equidade.

\subsection{Justiça como equidade}

Alguns estudos têm buscadono conceito de justiça como equidade de John Rawls ${ }^{1}$ uma das referências para a discussão do problema das desigualdades entre os diferentes grupos sociais (SOARES e MAROTTA, 2008; WALTERNBERG, 2008; VALLE, 2010; RIBEIRO, 2012; CRAHAY e BAYE, 2014).

Para Rawls (2008), num sistema equitativo, a distribuição dos direitos deve ser guiada por dois princípios:

1) Cada um tem o mesmo direito (irrevogável) a um sistema plenamente adequado de liberdades básicas iguais, que seja compatível com o sistema de liberdades para todos;

2) As desigualdades econômicas e sociais devem atender a duas condições: a) devem estar vinculadas a cargos e posições abertos a todos (princípio da

\footnotetext{
${ }^{1}$ Cientista político norte-americano, professor de filosofia política na Universidade Harvard e considerado um dos membros dos grandes pensadores do contratualismo liberal. Em 1971, publicou seu primeiro livro - Uma teoria da Justiça - no qual desenvolve os princípios da justiça que deveriam estruturar uma sociedade liberal.
} 
igualdade equitativa de oportunidades); b) devemdar o maior benefício aos membros mais desfavorecidos da sociedade (princípio da diferença).

$\mathrm{O}$ primeiro princípio é prioritário, pois diz respeito às questões constitucionais e essenciais, como a garantia da liberdade de pensamento. Ou seja, é um princípio voltado para a garantia dos direitos básicos e fundamentais dos cidadãos. O segundo princípio está subordinado ao primeiro, pois a distribuição dos bens sociais deve dar-se em um contexto em que as liberdades e os direitos básicos estejam plenamente garantidos. A distribuição dos bens sociais é válida no contexto institucional da sociedade e deve garantir as liberdades fundamentais (ou constitucionais) para todos, bem como a igualdade equitativa de oportunidades.

A igualdade equitativa de oportunidades consiste na correção dos "defeitos" da igualdade de oportunidades formais do pensamento liberal. Ela é definida não como uma concorrência aberta e formal aos postos públicos e posições sociais, mas sim como uma oportunidade equitativa para que todos possam obter tais cargos e posições sociais (RAWLS, 2008). Para ser organizada eficazmente, a justiça como equidade deve reconhecer as desigualdades existentes e buscar uma maneira de geri-las de forma a diminuí-las o máximo possível.

Segundo Rawls (2008), para conseguir realizar os objetivos de um sistema de cooperação equitativo, certas condições devem ser impostas de forma a limitar as desigualdades entre as pessoas. Um exemplo é a garantia de oportunidades iguais de educação, a despeito da renda familiar ou da origem social. Nessa perspectiva, o princípio da diferença, se ancora na exigência de que, qualquer que seja a amplitude das desigualdades de riqueza e renda, e qualquer que seja a vontade das pessoas de trabalhar para obter uma parte mais significativa da produção, as ações políticas e sociais devem contribuir para melhorar o destino das pessoas mais desfavorecidas da sociedade (RAWLS, 2008). Portanto, o princípio da diferença considera as desigualdades aceitáveis, com a condição de que a distribuição dos bens produzidos beneficie, prioritariamente, os menos favorecidos - aqueles que têm em comum com os outros cidadãos as liberdades básicas iguais e a igualdade equitativa de oportunidades mas que possuem menos renda e riqueza que os demais. 
Uma das limitações do pensamento de Rawls refere-se aos cidadãos desfavorecidos da sociedade, caracterizados somente em relação à riqueza e à renda que possuem e não em função de outras características, como cor/raça e gênero. Trata-se de uma limitação porque as desigualdades sociais não são engendradas apenas pela acumulação de renda e riqueza. Características como a cor/raça, o gênero, a religião entre outras, também fazem parte da estruturação das desigualdades sociais mas não são levadas em conta na teoria rawlsiana da justiça como equidade. Ou seja, não se trata de uma proposta que visa combater a meritocracia, até porque, a justiça como equidade alinha-se ao pensamento liberal que tem o próprio conceito de meritocracia como condição necessária para sua existência. Trata-se de uma proposta que aceita a desigualdade proveniente dos modelos meritocráticos, desde que certas condições (direitos fundamentais) sejam plenamente estendidas a todos e desde que se tenha uma ação complementar em favor dos socioeconomicamente desfavorecidos.

De acordo com Valle (2010), a educação, os conhecimentos e a escolarização não ocupam um lugar claramente definido na teoria de Rawls e não integram a lista dos chamados "bens sociais primários". Apesar disso, pode-se compreender que a educação é considerada como um direito social básico, fundamental ao desenvolvimento de pessoas livres e iguais. A autora resume as principais críticas encetadas à teoria política de Rawls da seguinte forma:

\footnotetext{
Uns consideram que ela reserva muito lugar ao Estado e não respeita o direito de propriedade; outros pensam que ela apresenta uma abordagem individualista e abstrata que desconsidera os valores de cada comunidade; outros ainda entendem que ela trata da justiça somente em termos socioeconômicos (VALLE, 2010, p. 30).
}

Baseado na argumentação de Rawls em favor da justa igualdade de oportunidades e evocando, de forma explicita, a distribuição equitativa dos "bens primários", ou seja, daqueles definidos como fundamentais, Valle (2010, p.30) afirma que a teoria do pensador estadunidense "parece inaugurar a passagem (ou seria a redução?) dos princípios de justiça e igualdade para a noção de equidade", pois é em razão de sua teoria que as políticas educacionais atuais têm privilegiado medidas compensatórias ou reparadoras. 
Apesar das limitações conceituais e ideológicas da teoria da justiça como equidade, que comprometem sua efetivação no plano real, há nela elementos importantes que podem contribuir para a busca de uma sociedade mais igual e justa. O princípio da diferença - um dos norteadores do pensamento de Rawls - é um desses elementos e é principalmente sobre ele que nos debruçamos na próxima seção deste texto para discutir a equidade na educação.

\subsection{Equidade ou igualdade?}

A apropriação do conceito de equidade pela educação pode assumir diversos significados, mas tem como solo comum o pressuposto de que a igualdade plena não é possível de ser alcançada, o que tornaria a equidade uma referência necessária para que a desigualdade entre diferentes grupos sociais possa ser a menor possível.

Para Gamoran (1989, apud Oliveira et all., 2013), a equidade requer que a educação seja um instrumento a ser usado com o objetivo de superar qualquer diferença preexistente entre os estudantes e não apenas aquelas relacionadas às condições sociais, como gênero, raça e status socioeconômico. Os recursos/ações educacionais devem ser destinados, prioritariamente, aos estudantes com resultados inferiores até o momento em que eles atinjam resultados semelhantes aos de seus colegas com bons resultados.

Segundo Oliveira et al (2013, p.34) os bens e direitos não são distribuídos igualmente e por isso,

(...) propugnar pela igualdade tem um sentido, propagandístico, de dever ser, posto que, por razões decorrentes da forma de organização social ou devido a diferenças individuais, tal objetivo não se realiza plenamente. Considerando-se isso, a solução que adotamos aqui foi a de identificar as desigualdades produzidas socialmente e buscar sua supressão, ou pelo menos, sua diminuição. Nesse contexto é que emerge o conceito de equidade, posto que o tratamento igual ou a igual distribuição dos direitos mantem as desigualdades de origem (ou iniciais ou de base) o que é mais grave quando os direitos não são garantidos a todos.

E complementam: 
na impossibilidade de os resultados serem iguais para todos, é inaceitável que eles sejam piores para qualquer grupo específico. É, apenas, nesse sentido que cabe o conceito de equidade. Quando não se atinge a universalização de determinado benefício, essa estabelece um critério para minimizar a desigualdade. Se a Educação é um direito, pressupõe-se que seja para todos, mas se isso não é possível, sua distribuição não pode ser feita preferencialmente para qualquer grupo em particular. Assim, a ideia de equidade, nesse caso busca uma menor desigualdade entre grupos (2013, p. 41).

Segundo Dubet (2004a), a equidade é uma forma de justiça social, na medida em que busca garantir o mínimo de recursos aos desfavorecidos. Um sistema educativo justo deve garantir, ao menos, os conhecimentos mínimos a serem alcançados por todos os estudantes. Essas garantias "visam a limitar os efeitos dos sistemas meritocráticos cuja mecânica muitas vezes leva à manutenção ou mesmo acentuação das desigualdades" (DUBET, 2004a, p. 546).

$\mathrm{Ou}$ seja, as ações calcadas no conceito da equidade não buscam desmantelar um sistema educacional meritocrático, mas, sim, serem ferramentas de correção de um "efeito colateral" - no caso a desigualdade - desse modelo típico das sociedades liberais. Segundo Dubet (2004a), é preciso aprender a defender princípios de justiça que sejam capazes de se combinar com o modelo meritocrático vigente.

É necessário introduzir uma dose de discriminação positiva a fim de assegurar maior igualdade de oportunidades. É preciso, também, garantir o acesso a bens escolares fundamentais, ou, para afirmar de modo mais incisivo, a um mínimo escolar. A escola justa deve, também, se preocupar com a utilidade dos diplomas. Ao mesmo tempo e de maneira oposta, ela deve velar para que as desigualdades escolares não produzam, por sua vez, demasiadas desigualdades sociais. Enfim, um sistema competitivo justo, como o da escola meritocrática da igualdade de oportunidades, deve tratar bem os vencidos na competição, mesmo quando se admite que essa competição seja justa. (DUBET, 2004a, p. 553).

Dubet (2004a) entende que o problema não é a meritocracia dos sistemas educativos, mas sim a ausênciainerente a esses sistemasde mecanismos de correção da desigualdade, que garantam um mínimo comum, em termos de resultados escolares, a todos os estudantes. 
Para Cury (2005, apud OLIVEIRA et all., 2013), a equidade é um conceito que busca equilibrar o princípio da igualdade e as situações concretas trazidas pelas diversidades situacionais e individuais. Esclarece, ainda, que quando uma situação real obstaculiza a igualdade, deve-se, então, buscar sua superação de modo a introduzir uma nova relação agora mais igualitária onde antes havia uma relação de desigualdade.

Com base nas definições de equidade apresentadas pelos autores acima citados, compreende-se, portanto, que a equidade não se propõe a efetivar a plena igualdade entre os diferentes grupos de indivíduos. Ao contrário disso, por causa das desigualdades existentes entre esses grupos em função de suas características sociodemográficas, a equidade se apresenta apenas como uma alternativa possível para a diminuição das desigualdades, mas não como uma alternativa de superação das mesmas.

Para Oliveira et all (2013), o conceito de equidade é insuficiente porque se aplica mais comumente à ideia de que o direito não será universalizado e, em razão disso, se estabelecem critérios para reduzir a desigualdade entre os grupos. Propõe como mais adequado o termo desigualdade para tratar do tema do aprendizado entre os diferentes subconjuntos de alunos, por compreender que as competências essenciais ou conhecimentos de base (CRAHAY, 2002), são universais, ou seja, devem ser alcançados por todos, independentemente da classe social, raça/cor e gênero dos estudantes. As diferenças de aprendizado são aceitáveis somente quando os conhecimentos de base (universais) forem alcançados por todos.

Assim, considerando que o conceito de equidade é insuficiente para a promoção da justiça na educação e que a plena igualdade dos conhecimentos de base é um direito de todos os indivíduos e que ele é realizável por meio de práticas pedagógicas eficazes (CRAHAY, 2002), esse estudo assume o conceito de igualdade,em suas diferentes dimensões, para investigar como se apresentam as desigualdades educacionais, no Brasil, considerando-se os sistemas de ensino e a desejável garantia, pelas escolas,da plena igualdade de aprendizagem dos conhecimentos de base por todos os alunos. 


\subsection{As três formas de justiça na educação: igualdade de oportunidade, de tratamento e de conhecimento}

Cotidianamente, os professores e os outros agentes escolares são confrontados por um questionamento ético relacionado ao princípio de justiça que irá nortear a ação pedagógica. De uma maneira geral, Crahay $(2002,2013)$ aponta a existência de duas compreensões de justiça na escola:

1) Justiça meritocrática: na escola, assim como na sociedade, os alunos são recompensados (ou valorizados) de acordo com seus próprios méritos. Nesta perspectiva, é legítimo dar notas maiores para os alunos que demonstraram ter um desempenho acadêmico melhor, assim como também é legítimo oferecer oportunidades de aprendizagem mais enriquecedoras e desafiadoras para os que aprendem mais rápido.

2) Justiça corretiva (ou compensatória): a escola deve promover a igualdade máxima para todos os alunos, de forma a garantir que todos dominem as competências desejadas. Para isso, a escola deve evitar aumentar as desigualdades de origem socioeconômica que se observam entre os alunos. Nessa concepção, defende-se que a escola deve oferecer a todas as crianças um mesmo ensino e, em seguida, oferecer uma atenção suplementar aos alunos que apresentarem alguma dificuldade de aprendizagem (CRAHAY, 2002).

Por um lado, pode-se argumentar que é dever da escola dar uma "compensação" aos menos favorecidos, por causa da desigualdade injustificada proveniente da origem social. Nesta perspectiva, cabe à escola exercer uma ação de amplitude inversa: dar mais atenção pedagógica aos alunos que possuem dificuldades de aprendizagem. Por outro lado, pode-se julgar legítimo estabelecer uma proporcionalidade direta entre a ação pedagógica e os talentos ou méritos individuais (CRAHAY, 2002, p. 43).

No que diz respeito ao plano econômico, o princípio meritocrático tende a argumentar que é normal, ou justo, dar mais àqueles que contribuem mais para o funcionamento da sociedade, seja pelos seus méritos, funções ou bens materiais. No mundo escolar, o argumento é que os alunos mais inteligentes e/ou aqueles que se esforçam para obter bons resultados escolares devem ser colocados nas melhores situações de ensino-aprendizagem e que a escola deve respeitar as 
características individuais de cada um (e, consequentemente, seu ritmo de aprendizagem), oferecendo oportunidades educativas proporcionais às suas qualidades, talentos, méritos. Além disso, o discurso meritocrático prega que é injusto que um aluno bom seja atrasado em seu desenvolvimento devido a obstáculos financeiros, geográficos, sociais ou pelo ritmo de progressão lento dos demais alunos.

A discussão da justiça na educação é abordada por Crahay (2002) à luz de três perspectivas: igualdade de oportunidades, de tratamento e de conhecimento. As duas primeiras perspectivas também são alvo das reflexões de Dubet (2004a), como será visto na seção seguinte, que apresenta brevemente as principais ideias dessas três abordagens teóricas de justiça na educação.

\subsubsection{Igualdade de oportunidades}

Foi a escola republicana francesa quem deu o pontapé inicial para que a ideologia da igualdade de oportunidade se concretizasse. A criação da escola obrigatória e gratuita na França não garantiu que todas as crianças tivessem acesso à mesma escola e, portanto, à mesma competição. Os filhos dos operários frequentavam uma escola que não era, nem de longe, a mesma dos filhos da burguesia. Tanto em uma quanto em outra, a escola selecionava os melhores alunos, não possibilitando a participação de todos na mesma competição. Todos passaram a ter igual acesso à educação, mas não passaram a ter igual acesso à qualidade do ensino. Embora a qualidade fosse diferente - o que não permitia a igualdade de resultados escolares - a escola republicana colocou as premissas para o desenvolvimento da igualdade de oportunidades, na medida em que, ao universalizar o acesso à educação elementar, instaurou uma mistura social, na qual todas as crianças passaram a ter acesso à educação (DUBET, 2004b). Mesmo que de forma insatisfatória - porque não garante a igualdade de aprendizado -, a igualdade de oportunidades atende a um princípio de justiça: dar acesso a todos à educação. Assim, Dubet (2004b) ressalta que, a partir da garantia do acesso, o sucesso e o fracasso escolar passaram a ser justificados pelo mérito, sem levar em consideração a qualidade da educação ofertada. 
No momento em que todos os alunos, de todas as classes sociais, passaram a ter acesso à escola, o problema da desigualdade de acesso foi substituído pela desigualdade de sucesso escolar (OLIVEIRA, 2007; DUBET, 2004a). Na perspectiva meritocrática, a desigualdade de sucesso escolar está intrinsecamente relacionada ao merecimento, ao esforço que cada um dedica às tarefas escolares. Ela não considera a desigualdade da qualidade do ensino que é ofertado. Segundo Dubet (2004a, p. 541), a escola "não se tornou mais justa porque reduziu a diferença quanto aos resultados favoráveis entre as categorias sociais e sim porque permitiu que todos os alunos entrassem na mesma competição". Permitir que todos participem da mesma competição é uma prerrogativa da justiça meritocrática mas está longe de ser uma garantia da plena justiça escolar.

Desde o início da escolarização, os alunos das classes sociais privilegiadas possuem escores educacionais melhores que os alunos das classes desfavorecidas. Em seguida, essas desigualdades e as pequenas diferenças do início da escolarização se acentuam ao longo da trajetória escolar, e isso mostra que a escola não consegue neutralizar os efeitos das desigualdades culturais e sociais.

Dois aspectos apresentados por Dubet (2004b) explicam a força e a estabilidade da influência das desigualdades sociais sobre as desigualdades escolares e denunciam a baixa capacidade da escola para neutralizar os efeitos do contexto social. O primeiro desses aspectos considera que os diversos grupos culturais e sociais desenvolvem precocemente nas crianças um conjunto de atitudes e competências mais ou menos favoráveis ao sucesso escolar. Segundo Dubet (2004b) cada grupo valoriza de forma diferente os estudos, dando às crianças as competências cognitivas mais ou menos próximas das expectativas da escola. Isto faz com que as crianças dos grupos sociais mais favorecidos tenham uma familiaridade imediata com a cultura escolar, enquanto as crianças dos grupos menos favorecidos devem passar por um processo de aculturação para se tornarem mais próximos desse mundo escolar. O segundo aspecto, complementar ao primeiro, enfatiza o papel dos recursos materiais e financeiros e as estratégias familiares. Para Dubet (2004b) cursos particulares, cursos de línguas, acompanhamento do trabalho escolar em casa, escolha das melhores escolas, entre outros aspectos, são ações familiares que acabam por aumentar as diferenças escolares entre os estudantes. Os grupos mais favorecidos conhecem e utilizam 
melhor as estratégias e os recursos educativos, enquanto as famílias dos meios sociais menos favorecidos têm mais dificuldade para se apropriar desses recursos, e para desenvolver estratégias para tornar a trajetória escolar de seus filhos mais eficaz ou, simplesmente, pensam que isso não é de sua jurisdição (DUBET, 2004b).

Esses dois processos juntos criam desigualdades definitivas e distinções escolares menos perceptíveis, que reproduzem as hierarquias sociais e organizam as escolas de maneira tal que as diferenças escolares refletem as diferenças sociais.

Em função de suas políticas e de suas tradições, cada sistema escolar pode ser mais ou menos próximo de um ideal de igualdade de oportunidades, mas nenhum conseguirá verdadeiramente se proteger da influência das desigualdades sociais (DUBET, 2004b). A igualdade de oportunidades não produz, portanto, igualdade de resultados.

Todavia, a tomada de consciência de que as desigualdades sociais se sobrepõem às desigualdades escolares não coloca totalmente em xeque o modelo educativo de igualdade de oportunidades, tanto que se pode acreditar que a competição escolar é justa e imparcial em um mundo injusto e imperfeito. Como forma de defender a desigualdade justa, a perspectiva da igualdade de oportunidades repousa sobre duas ideias principais:

1) No início da escolarização, todos os alunos são considerados iguais e todos tem o direito de esperar obter os melhores resultados. Os programas são estabelecidos de forma a permitir que todos os alunos tenham acesso ao mesmo ensino e à mesma cultura. Assim, a priori, o aluno tem não apenas o direito, mas também o dever de esperar por um maior sucesso escolar e social.

2) Como todas as escolas, a escola da igualdade de oportunidades também orienta e hierarquiza os alunos em função de seus desempenhos. Isso implica considerar que os alunos são necessariamente desiguais. Isso pode ser verificado, por exemplo, na forma como os alunos são alocados nas escolas e nas turmas, criando escolas e/ou turmas heterogêneas/homogêneas do ponto de vista social e cognitivo.

Desta forma, Dubet (2004b) denuncia que os alunos são colocados no âmago de uma contradição: eles são considerados como iguais, mas são inseridos 
numa lógica escolar meritocrática cuja finalidade é lhes tornar desiguais. Então, como ficar igual, tendo desempenhos e resultados desiguais? Para sair desse impasse tornou-se imperativo inventar uma ficção (DUBET, 2004a, 2004b), fazendo com que o desigual desempenho dos alunos seja o produto de seu próprio mérito, conhecido como a manifestação de sua liberdade. Segundo Dubet (2004b), a ficção mais eficaz consiste em fazer com que os resultados escolares dos alunos sejam a consequência direta do seu trabalho e de sua dedicação. "Falta de trabalho", "falta de seriedade", "falta de atenção" são as explicações mais banais e frequentes para as desiguais performances escolares dos alunos. O aluno é, portanto, o próprio responsável pelo seu fracasso escolar, ao mesmo tempo em que sua igualdade fundamental é preservada, pois tudo se passa como se ele tivesse decidido livremente seu desempenho escolar, trabalhando mais ou menos, se dedicando mais ou menos. Dubet (2004b) afirma, ainda, que essas ficções são necessárias e cruéis. São necessárias porque permitem aos indivíduos se perceberem como livres e iguais a despeito da formação das desigualdades educacionais imbricadas nessa lógica; são cruéis porque quando os alunos fracassam, mesmo tendo trabalhado e se dedicado, não podem encontrar uma explicação para o seu fracasso que não seja seu próprio esforço.

Uma vez estabelecida a igualdade da oferta escolar, novos desequilíbrios, ou desigualdades, se tornaram visíveis: as escolas não são iguais entre si (DUBET, 2004a). Cada uma tem as suas particularidades e especificidades: número de alunos, tamanho das turmas, quantidade e qualidade dos recursos materiais e pedagógicos, qualidade e estabilidade da equipe pedagógica etc. Todas essas características variam de uma escola para outra. Se a oferta quantitativa de oportunidades escolares está garantida, o mesmo não acontece com a qualidade dessa oferta. Dito de outa forma, a variação das características escolares não se dá no sentido de garantir a igualdade de resultados. Não é porque todos os alunos frequentam a escola que eles vão ter acesso ao mesmo ensino, ou melhor, vão ter acesso a um ensino com a mesma qualidade.

A partir da compreensão de que o princípio de justiça escolar baseado na igualdade de oportunidades não é suficiente para garantir igualdade plena de resultados escolares entre as escolas e entre os indivíduos, começou-se a pensar em termos de equidade escolar, enfatizando a necessidade de se dar mais a todos 
e, principalmente, àqueles que possuem menos, o que reintroduz oprincípio da diferença de Rawls (2008).

A igualdade de oportunidades é o modelo educacional dominante e é inerente ao modelo de justiça meritocrática (CRAHAY, 2002, 2013). Embora seja um modelo baseado em princípios de justiça, ela produz novas formas de injustiça na escola (DUBET, 2004a) que devem ser combatidas através da definição de conhecimentos de base que devem ser adquiridos por todos os subconjuntos de indivíduos (CRAHAY, 2002, 2013).

\subsubsection{Igualdade de tratamento}

A igualdade de tratamento é uma perspectiva de justiça que defende que as escolas de um mesmo sistema devem oferecer um ensino com a mesma qualidade. Isso implica em homogeneizar as condições de ensino e tornar equivalente, em todas as escolas, a oferta dos recursos pedagógicos. Por meio da publicação de programas, planos de estudo, manuais e ações de formação e supervisão, os responsáveis educacionais organizariam e administrariam de forma igualitária a qualidade das oportunidades educativas oferecidas aos estudantes. Isso faria com que os conteúdos, os métodos e as condições de ensino fossem uniformes, homogêneas, iguais. No Reino Unido, a proposta do Comprehensive schools se alinhava à ideia da igualdade de tratamento e defendia que:

\footnotetext{
(...) as escolas devem oferecer uma formação comum: os alunos deveriam todos receber o seu ensino nas mesmas escolas e nas mesmas turmas, quaisquer que fossem as suas origens socioeconômicas ou o seu êxito escolar. Colocar todos os alunos na mesma escola e numa mesma área tem uma significação evidente: a) todos os alunos são seres humanos iguais; b) todos possuem uma mesma capacidade inata, quaisquer que sejam as suas origens socioeconômicas e c) todos podem desfrutar de um ensino mais ou menos semelhante e beneficiar do mesmo direito de serem bem-sucedido nas suas vidas, sem distinção de classe. (BECK, 1990, p. 17, apud CRAHAY, 2002, p.65)
}

No mundo francófono, a defesa da igualdade de tratamento denuncia o apartheid pedagógico da desigualdade de oportunidades e rejeita a criação de escolas guetos (escolas formadas por estudantes de baixo status socioeconômico) 
e escolas santuários (escolas formadas por estudantes de alto status socioeconômico).

Complementarmente, Dubet (2004a, 2004b) afirma que para se perseguir o ideal da igualdade plena é necessário definir aquilo que os membros de uma sociedade têm em comum. A cultura escolar, os conhecimentos e as competências transmitidas não são apenas suportes da seleção. Esses elementos têm um valor em si mesmo, são um bem fundamental que irá nortear as ações e o aprendizado dos indivíduos. É preciso, portanto, definir o que a escola obrigatória deve garantir aos alunos, visando à igualdade de resultados.

A definição de uma cultura comum como um bem garantido a todos não se apresenta como uma escolha pedagógica, mas sim como uma escolha de justiça, uma escolha política, cuja importância será manifestada em termos pedagógicos e de organização escolar. Uma vez que esse bem comum tenha sido definido, ele deverá se tornar a finalidade da escola, o objetivo a ser mensurado. Neste ponto, mais uma questão importante se coloca: quem define aquilo que deve ser comum a todos? Para Dubet (2004a), essa definição segue uma concepção que preconiza uma "boa vida", entendendo-a como uma vida desejável para todos. Trata-se de garantir a todos os elementos básicos (comuns) para que todos sejam capazes de construir uma vida digna. Uma crítica feita ao estabelecimento de uma cultura escolar comum é que a definição do comum fará baixar o nível de exigência e, consequentemente, o nível de desempenho dos melhores alunos. No entanto, Dubet (2004a, p.547) defende:

O sistema justo, ou menos injusto, não é o que reduz as desigualdades entre os melhores e os mais fracos, mas o que garante aquisições e competências vistas como elementares para os alunos menos bons e menos favorecidos.

Essa concepção implica na definição de um conjunto de conteúdos da cultura escolar, ou, nas palavras de Crahay (2002), de conhecimentos de base, podendo os melhores alunos tirar um proveito melhor e progredir mais depressa, sem que os alunos com mais dificuldades escolares sejam abandonados ou prejudicados em seus percursos.

Dubet (2004a) também chama a atenção para a heterogeneidade dos estudantes afirmando que é justamente em nome da heterogeneidade que se torna 
necessário definir uma cultura comum para educar alunos diferentes. A fixação dessa cultura comum deve atenuar os efeitos das desigualdades da competição meritocrática, garantido alguma coisa de comum a todos os alunos.

No plano técnico, a igualdade de tratamento traduz-se por uma fraca variância interescolar dos recursos humanos e materiais e das oportunidades educativas. Do mesmo modo, manifesta-se por: 1) fracas variações nos níveis socioculturais e socioeconômicos das escolas (portanto, uma fraca variância dos índices de recrutamento social das escolas); 2) fraca ligação estatística entre a qualidade do ensino e a origem social, e, também, entre a qualidade do ensino e o nível intelectual (QI) dos alunos que frequentam as mesmas escolas. O quadro abaixo apresenta as principais características dessa perspectiva.

\section{Quadro 1: Igualdade de Tratamento}

\begin{tabular}{|c|l|}
\hline Afirma & $\begin{array}{l}\text { A capacidade que todos têm para realizar as aprendizagens } \\
\text { fundamentais e, por isso, para beneficiar-se de um ensino de base. }\end{array}$ \\
\hline Admite & $\begin{array}{l}\text { A existência de dons, de potencialidades ou aptidões naturais. } \\
\text { Resultados desiguais desde que os alunos tenham podido beneficiar- } \\
\text { se de condições de aprendizagem de qualidade equivalente. }\end{array}$ \\
\hline Denuncia & $\begin{array}{l}\text { A desigual qualidade do ensino, responsável por conhecimentos } \\
\text { desiguais. As escolas santuário e as escolas gueto, as classes de } \\
\text { níveis, as áreas explícitas e implícitas que geram uma qualidade de } \\
\text { ensino desigual. }\end{array}$ \\
\hline Defende & $\begin{array}{l}\text { A escola única ou o ensino compreensivo e, nomeadamente, o } \\
\text { tronco comum para o ensino básico. }\end{array}$ \\
\hline Fonte: Crahay (2002)
\end{tabular}

Crahay (2002) aponta duas críticas a essa abordagem. A primeira diz respeito ao dever do Estado, que tem a função precípua de garantir o bem-estar geral antes de contribuir para a promoção individual de cada cidadão. Por isso, o serviço público deve ser imparcial e atender aos interesses da coletividade. Desta forma, para ser justa, a escola deve oferecer o mesmo serviço a todas as crianças, valorizando conhecimentos e competências de importância geral e neutralizando os particularismos regionais, familiares e culturais. Por defender que todas as crianças aprendam conhecimentos de interesse geral e razão universal, a igualdade de tratamento enfatiza que os estudantes devem se libertar de sua família e da comunidade a qual pertencem porque são, na maior parte das vezes, portadoras de 
crenças e tradições irracionais. Assim, torna-se mais forte a necessidade de isolar a escola da vida e dos interesses da comunidade à qual está inserida. Esse modelo pedagógico entra em conflito com o que privilegia o desenvolvimento individual, o laço e o enraizamento local. Para Crahay (2002), este é o principal desafio da escola do século XXI: conciliar a luta contra as desigualdades sociais e a realização pessoal de cada indivíduo e favorecer a integração do indivíduo na sua comunidade.

A segunda crítica refere-se à teoria da violência simbólica de Bourdieu e Passeron (1969). A escola, ao se autoproclamar neutra e imparcial, não faz outra coisa que reproduzir a estratificação social não-igualitária que pretende transformar. Ao considerar todos os alunos iguais em direito, mostra-se indiferente às desigualdades iniciais, acabando por legitimar as capacidades desiguais construídas anteriormente no meio familiar e social. A escola adota uma maneira de ser (habitus) própria da classe dominante, bem como valoriza conhecimentos e competências por ela determinados, exercendo assim, uma violência simbólica sobre as crianças das classes populares. Sob o argumento da imparcialidade, a escola aplica a todos as normas das classes sociais dominantes, gerando desigualdade e contribuindo para a sua reprodução.

Para Perrenoud (1995, apud Crahay, 2002), é evidente que uma ação pedagógica totalmente indiferenciada aprofunda a desigualdade e que a igualdade de tratamento pedagógico tem efeitos contraditórios, pois ao tentar corrigir ou compensar a desigualdade entre os alunos, a escola pode acabar privilegiando os mais favorecidos, se a sua atuação não for controlada e revista constantemente. Para ele, há processos interativos na sala de aula que ora amplificam as diferenças interindividuais e ora as reduzem.

Portanto, apartir dessas críticas afirma-se que a igualdade de tratamento, assim como a igualdade de oportunidades, é condição necessária mas não suficiente para a promoção de uma escola justa.

\subsubsection{Igualdade de conhecimento}

Para Crahay (2002), a melhor forma de atenuar os efeitos colaterais da igualdade de oportunidades é o princípio da igualdade de conhecimentos, que 
defende um ensino organizado em função dos objetivos a serem atingidos por todos.

A Pedagogia do Domínio dos Conhecimentos (PDC), representante dessa abordagem, afirma que o nível de uma competência atingido pelos alunos está relacionado à adequação entre as oportunidades educativas oferecidas e o tempo necessário para consolidar uma aprendizagem.

As potencialidades de aprendizagem de um indivíduo não são fixadas no nascimento. Pelo contrário, são fruto da sua história de vida, das suas experiências e da riqueza dos estímulos oferecidos pelo seu meio social. Por isso, é legítimo reclamar não apenas o direito à igualdade de oportunidades ou à igualdade de tratamento, mas também e, sobretudo, o direito à igualdade de conhecimentos. Essa perspectiva propõe que a aferição da aprendizagem de uma competência adquirida por um indivíduo se dá pela relação entre o tempo que se consagra à aprendizagem e o tempo que ele necessita para dominar tal competência. Ou seja, deve-se dedicar um tempo suplementar de aprendizagem aos alunos que ainda não conseguiram consolidar os conhecimentos de base.

Duas são as críticas feitas à essa perspectiva. A primeira diz respeito ao efeito Robin Hood. Para alcançar o seu objetivo, a PDC conserva uma fase majoritária de ensino coletivo, oferecendo ações pedagógicas simultâneas aos alunos com ritmos de aprendizados diferentes. Crahay (2002, p.84) explica:

\footnotetext{
Aos mais lentos, impõe uma aceleração do seu ritmo de aprendizagem e oferece-lhes procedimentos corretivos quando não atingem o nível de domínio. De forma complementar, atrasa a progressão dos mais rápidos quando os seus condiscípulos mais lentos passam por ciclos de compensação ou quando, em certas modalidades de aplicação, são convidados a agir como tutores em proveito dos mais lentos.
}

Ou seja, a PDC estabelece que, após a fase do ensino coletivo, a prioridade deve recair sobre os alunos que ainda não conseguiram adquirir os conhecimentos ensinados. Isso pode levar a um atraso na progressão da aprendizagem dos alunos mais rápidos. Uma hipótese colocada é que quanto maior for a qualidade do ensino, menores serão as diferenças de resultados educacionais. No entanto, mesmo havendo condições perfeitas, as diferenças entre os alunos sempre 
existirão e elas deverão ser constantementelevadas em consideração na ação pedagógica.

A segunda crítica refere-se ao respeito à diversidade. Segundo Perrenoud (1995, apud Crahay, 2002), com base em Rousseau, a desigualdade entre os homens tem origem social. Para Perrenoud, a fonte da desigualdade não está somente na diferença entre os indivíduos, mas também no status que as instituições sociais dão a essas diferenças bem como no tratamento que lhes reservam. Assim, as diferenças existentes, traduzidas em desigualdades, têm, também, uma origem social que é produzida pelos próprios homens.

Seguindo essa corrente de pensamento, Crahay $(2002,2013)$ afirma que nenhum dispositivo didático é capaz de garantir a total igualdade entre os indivíduos. Eles podem suscitar aprendizagens substanciais para a maioria dos alunos e, assim, obter de (quase) todos desempenhos de qualidade. No entanto, jamais serãocapazes de impedir que alguns alunos transformem as pequenas diferenças que subsistem numa hierarquia de valores. Ou seja, a diferença na igualdade sempre vai existir em qualquer sistema de ensino calcado em princípios de justiça.

Segundo Crahay $(2002,2013)$ existem, grosso modo, dois tipos de organizações sociais escolares: 1) aquelas com objetivos individualistas, nas quais as metas dos diversos indivíduos não se relacionam. Ou seja, os projetos de cada individuo não interferem e nem interagem com os demais; 2) aquelas cujos objetivos são cooperativos e as metas individuais estão relacionadas entre si de tal formaque um indivíduo só pode alcançar o seu objetivo se os outros também o conseguirem.Nessas instituições de caráter cooperativo, "os ganhos individuais são diretamente proporcionais à qualidade do trabalho do grupo e espera-se que todos os membrosse beneficiem" (CRAHAY, 2002).

Por meio de um trabalho de síntese, os pesquisadoresJohnson, Maruyama, Johnson, Nelson e Skon (1981), apresentaram 122 trabalhos experimentais e semiexperimentais que confrontaram quatro modalidades pedagógicas, a saber: individualização do ensino, competição entre os alunos, cooperação dos alunos no seio de grupos colocados em competição e a cooperação dos alunos sem competição intergrupal. Os efeitos destas modalidades são verificados por meio do progressos dos alunos mensurados por testes preliminares e posteriores. 
O principal resultado desses trabalhos evidencia os efeitos positivos da modalidade pedagógica cooperativa em qualquer que seja a disciplina avaliada. Além disso, a cooperação não se revelou superior às outras modalidades quando as práticas pedagógicas priorizavam a "decoreba" e a correção de exercícios. Por fim, os efeitos positivos da cooperação variavam segundo o numero dos grupos: quanto menor o numero de indivíduos em um grupo cooperativo, maior é o efeito dessa modalidade pedagógica (CRAHAY, 2002).

Em 1995, Qin, Johnson e Johnson(apud CRAHAY, 2002) apresentamuma meta-análise com 63 estudos que têm como objetivo rebater a ideia estadunidense de que os efeitos positivos da cooperação limitam-se às tarefas rotineiras e que as aprendizagens mais complexas não seriam plenamente consolidadas por meio da cooperação. A meta-análise realizada por esses autores concentra-se em estudos de resolução da problemas, dividindo-os em duas categorias: 1) problemas com forte conotação verbal e problemas essenialmente não-verbais e 2) problemas bem definidos (aqueles que determinam uma meta claramente especificada a ser alcançada) e problemas mal definidos (supõe que o sujeito esclareça por si mesmo o objetivo a ser alcançado). Estas analises foram realizadas na pré-escola, e nos níveis primário, secundário e superior e confrontaram três modelos pedagógicos: grupos cooperativos, grupos cooperativos colocados em competição no seio da turma e competição individualizada (entre alunos).

Novamente, os resultados desta meta-análise evidenciam os efeitos positivos da cooperação em todos os "tipos" de problemas (verbais, não-verbais e bem/mal definidos) e em todos os níveis de ensino analisados.

Para Crahay (2002), a aprendizagem cooperativa se assenta na hipótese de que todos os indivíduos podem trazer contribuições específicas para a construção coletiva do conhecimento e, por isso, recorrer à explicação entre pares é uma possibilidade de prática pedagógica que pode ser exitosa.

Para verificar se as explicações entre pares são eficazes e saber quem se beneficia mais com elas, o explicando ou o explicador, Crahay (2002), recorre à meta-análise de Cohen, Kulik e Kulik (1982, apud CRAHAY, 2002), que sintetizaram 65 estudos sobre o efeito das explicações entre pares. Dos estudos analisados, 52 apontaram para os consideráveis ganhos de aprendizagem por meio da explicação entre pares, sendo que 45 ressaltam o efeito altamente positivo na 
aprendizagem dos explicandos.Essas investigações também ressaltaram os ganhos de aprendizagem dos alunos explicadores, revelando que a adoção de práticas pedagógicas colaborativas traz efeitos positivos para todos os alunos: explicandos e explicadores. Crahay (2002, p. 411) sintetiza os dados dos estudos analisados por Cohen et al (1982) da seguinte forma:

\begin{abstract}
Em suma os efeitos das explicações são esmagadoramente positivos. $\mathrm{Na}$ maior parte dos casos, os explicandos retiram francos benefícios dessas lições particulares e da ajuda de colegas mais competentes que eles na área em que experimentam dificuldades de aprendizagem. Poder-se-ia temer um reverso da medalha em termos de desvantagens afetivas induzidas por esta situação de dependência cognitiva relativamente a colegas reconhecidamente mais competentes; os resultados dos estudos permitem dissipar esse temos. Quanto aos explicadores, na maioria dos casos, não perdem o seu tempo quando partilham os seus conhecimentos com outros alunos menos bem formados: são numerosos aqueles que aumentam o seu grau de domínio das competências que ensinam.
\end{abstract}

Nesse sentido, a cooperação como forma de orgaização escolar se coloca como a mais adequada para o favorecimento de uma prática pedagógica fundamentada na ideologia da igualdade de conhecimento. Uma possível aposta seria transformar as escolas em comunidades de discentes no qualtodas as individualidades contribuem com a sua quota-parte para o edifício comum, ao mesmo tempo que se preocupam no sentido de todos os avanços do conhecimento se repercutirem nos demais(CRAHAY, 2002, p. 413).

Uma das novas formas de organização escolar diz respeito à quantidade de tempo que os alunos precisam para consolidar uma determinada aprendizagem. Alguns estudos buscaram averiguar a gestão do tempo escolar com o objetivo de verificar se é ofertada aos alunos a mesma quantidade de tempo.

Para tratar desse tema, Crahay (2002) apresenta a pesquisa de Thirifanys (1985) que observou como se dá a organização dos tempos escolares na escola primária. $\mathrm{O}$ estudo observou quatro turmas do $1^{\circ}$ ano primário durante 8 dias inteiros em cada turma. Os tempos escolaes foram divididos em quatro categorias: 1) Tempo de recreação; 2) Tempos mortos (inatividade e interrupções da aula); 
3)Tempo de organização; e 4) Tempo reservado diretamente à ação educativa, denominado de TRAE, que foi calculada com base no seguinte cálculo:

$$
\text { TRAE }=\text { TOficial }- \text { TRecreação }- \text { TMortos }- \text { TOrganização }
$$

De acordo com os dados empíricos coletados, cada turma obteve tempos de TRAE diferenciados, envidenciando que alunos de uma determinada turma possuíam mais tempo reservado à ação educativa que outras turmas. $\mathrm{O}$ quadro 2 apresenta a quantidade de tempo de cada categoria por turma.

\section{Quadro 2: Tempo em minutos destinado a cada categoria}

\begin{tabular}{|c|c|c|c|c|c|}
\hline Categoria & Turma A & Turma B & Turma C & Turma D & Média \\
\hline $\begin{array}{ll}\text { Tempo } & \text { de } \\
\text { recreação } & \end{array}$ & $\begin{array}{l}223,5^{\prime} \\
(10 \%)\end{array}$ & $\begin{array}{c}396^{\prime} \\
(19 \%)\end{array}$ & $\begin{array}{c}242^{\prime} \\
(11 \%)\end{array}$ & $\begin{array}{l}308,5^{\prime} \\
(13 \%)\end{array}$ & $\begin{array}{c}295,5^{\prime} \\
(13,5 \%)\end{array}$ \\
\hline $\begin{array}{l}\text { Tempos } \\
\text { mortos }\end{array}$ & $\begin{array}{c}164,5^{\prime} \\
(7 \%)\end{array}$ & $\begin{array}{l}173^{\prime} \\
(8 \%)\end{array}$ & $\begin{array}{l}267,5^{\prime} \\
(12 \%) \\
\end{array}$ & $\begin{array}{c}268,5^{\prime} \\
(11,5 \%) \\
\end{array}$ & $\begin{array}{l}218,5^{\prime} \\
(9,5 \%)\end{array}$ \\
\hline $\begin{array}{l}\text { Tempo de } \\
\text { organização }\end{array}$ & $\begin{array}{c}274^{\prime} \\
(11,5 \%) \\
\end{array}$ & $\begin{array}{c}302^{\prime} \\
(14,5 \%) \\
\end{array}$ & $\begin{array}{c}412^{\prime} \\
(18,5 \%) \\
\end{array}$ & $\begin{array}{c}405^{\prime} \\
(17,5 \%) \\
\end{array}$ & $\begin{array}{c}348,5^{\prime} \\
(15,5 \%) \\
\end{array}$ \\
\hline $\begin{array}{l}\text { Tempo } \\
\text { reservado } \\
\text { ação } \\
\text { educativa }\end{array}$ & $\begin{array}{c}1679^{\prime} \\
(71,5 \%)\end{array}$ & $\begin{array}{c}1219^{\prime} \\
(58,5 \%)\end{array}$ & $\begin{array}{c}1219^{\prime} \\
(58,5 \%)\end{array}$ & $\begin{array}{l}1367^{\prime} \\
(58 \%)\end{array}$ & $\begin{array}{c}1391^{\prime} \\
(61,5 \%)\end{array}$ \\
\hline Total & $\begin{array}{c}2341^{\prime} \\
(100 \%)\end{array}$ & $\begin{array}{c}2090^{\prime} \\
(100 \%)\end{array}$ & $\begin{array}{l}2140,5^{\prime} \\
(100 \%)\end{array}$ & $\begin{array}{c}2349^{\prime} \\
(100 \%)\end{array}$ & $\begin{array}{c}2253^{\prime} \\
(100 \%)\end{array}$ \\
\hline
\end{tabular}

Fonte: (Crahay, 2002)

Como observado, a variabilidade do tempo entre as turmas é significativa. As turmas B, C e D tiveram aproximadamente 58\%de TRAE (tempo reservado à ação educativa) e a turma A teve $71,5 \%$, o que evidencia que os alunos da turma A tiveram 13,5\% a mais de TRAE. Em termos de minutos, nesses oito dias, os alunos da turma A se beneficiaram de 300 minutos mais que os alunos da turma $\mathrm{D}, 380$ minutos a mais que os alunos da turma $\mathrm{C}$ e 460 minutos a mais que os aluno da turma B. Se compararmos o tempo de ensino entre as turmas A e B, registra-se uma diferença de 7 horas 40 minutos.

Esses resultados apontam para uma oferta desigual de oportunidades educativas junto aos alunos de uma mesma escola. Aos alunos da turma A é ofertado uma quantidade de TRAE maior que para os alunos das outras três 
turmas. A pesquisa não apresentou dados sobre desempenho, de forma que não é possível associar a quantidade de tempo ao desempenho escolar.

Outro estudo apresentado por Crahay (2002) foi o de Carroll (1963, apud Crahay, 2002). Carroll definiu o tempo de aprendizagem como o tempo que o professor dedica à aprendizagem mais o tempo de empenho do aluno na aprendizagem. Ou seja, considera o tempo de aprendizagem de maneira interativa, considerando o tempo que professores e estudantes dedicam ao processo ensinoaprendizagem. A partir dessa definição, a investigação buscou mensurar o tempo de empenho dos alunos através do julgamento da concetração dos alunos com base em atitudes não verbais.

Os principais resultados encontrados evidenciam a forte relação entre o tempo que o aluno dedica à apropriação de uma aprendizagem e o tempo de ensino dedicado pelo professor àquela aprendizagem. Quanto mais o aluno se empenha e dedica à aprendizagem, maior é o tempo que o professor dedica ao ensino. Também constatou-se uma relação positiva entre o tempo investido pelo aluno na aprendizagem e as competências adquiridas.

Outro resultado encontrado por Carroll aponta que o tempo de empenho dos alunos nas atividades de ensino é mais elevado quando o professor gere o grupo de forma coletiva (ou frontal) do que quando organiza trabalhos individuais.Quanto melhor o professor gere o tempo disponível, quer dizer, quanto maior é o tempo consagrado ao ensino das competências desejadas pelos

programas e avaliada pelos testes, mais se torna provável que os alunos se empenhem ativamente na aprendizagem destas competências e tenham bons resultados nos testes de rendimento. Nesse sentido, Crahay (2002, p.289) aponta que antes de se pensar em tornar mais longo o ano escolar, convém, talvez, pensar em melhor utilizar o tempo disponível.

\subsubsection{Ações pedagógicas de discriminações negativas, positivas e neutras}

Sintetizando as propostas das três abordagens sobre a justiça escolar, Crahay $(2002,2013)$ traz as considerações de Perrenoud, que classifica as ações pedagógicas em discriminações negativas, positivas e neutras. 
As ações pedagógicas de discriminação negativa baseiam-se no mérito e, por isso, privilegiam aqueles que já possuem bons resultados escolares. Estas ações exercem aquilo que Walberg e Tsai (1983, apud CRAHAY, 2002) chamaram de efeito Mathieu ${ }^{2}$, amplificando assim as desigualdades e alinhandose à ideologia da igualdade de oportunidades.

As ações de discriminações neutras estão em conformidade com o conceito de igualdade de tratamento, uma vez que as práticas escolares não visam favorecer um grupo específico.

Já as ações de discriminações positivas alinham-se à igualdade de conhecimento, uma vez que buscam favorecer os desfavorecidos e, por isso, tendem a reduzir as desigualdades. A discriminação positiva consiste na tomada de consciência das desigualdades reais e nas ações implementadas para compensálas. Uma das premissas da discriminação positiva é evitar a formação, de um lado, de guetos de cultura, dinheiro e qualidade e, de outro lado, guetos de pobreza e dificuldades. Tanto dentro da rede privada quanto dentro da rede pública de ensino existem mecanismos de mercados escolares (DUBET, 2004a), ou seja, escolas fortes e escolas fracas. Uma das maneiras de se resistir à formação de escolas guetos é introduzir mecanismos compensatórios centrados nos alunos. A justiça na educação consiste, então, em articular as três formas de igualdade. Para se ter uma real situação de justiça no sistema educacional, é preciso ultrapassar as premissas da igualdade de oportunidade e de tratamento e implementar ações específicas, de discriminação positiva, que promovam a igualdade de conhecimentos de base entre os diferentes subconjuntos de indivíduos.

O quadro abaixo, organizado por Oliveira et al. (2013), sintetiza os princípios e as características das três perspectivas de igualdade na educação:

\footnotetext{
2 O termo "efeito Mateus" foi criado pelo sociólogo Merton na década de 1960. A inspiração está na Bíblia (no Evangelho de Mateus), numa história contada por Jesus, na qual o senhor deu a três empregados 5 talentos, 2 talentos e 1 talento, respectivamente. $\mathrm{O}$ que recebeu mais conseguiu duplicar o dinheiro; aquele que recebeu 2 talentos também dobrou a quantia; mas aquele que recebeu 1 talento escondeu seu dinheiro embaixo da terra, com medo de ser roubado. Ao pedir conta do dinheiro, o senhor repreendeu o servo que recebeu 1 talento, dizendo que ele foi mau e preguiçoso: "tirai este talento e daí ao que tem dez. Dar-se-á ao que tem e terá em abundância. Mas ao que não tem, tirar-se-á mesmo aquilo que julga ter”. Merton usou esta parábola para caracterizar as situações onde pequenas diferenças iniciais são ampliadas no tempo. Na educação, ele expressa a situação em que aqueles que possuem, pela sua natureza ou pela sua origem social, talentos mais apurados, recebem mais do sistema educativo. Ou seja, se dá mais para quem tem mais, o que contribui para a ampliação de diferenças que se traduzem em desigualdades.
} 
Quadro 3: Síntese de princípios e características das concepções de justiça

\begin{tabular}{|c|c|c|c|}
\hline & $\begin{array}{l}\text { Igualdade de } \\
\text { oportunidades }\end{array}$ & $\begin{array}{l}\text { Igualdade de } \\
\text { tratamento }\end{array}$ & $\begin{array}{l}\text { Igualdade de } \\
\text { conhecimento }\end{array}$ \\
\hline $\begin{array}{l}\text { Concepção de } \\
\text { justiça }\end{array}$ & Justiça meritocrática & Justiça distributiva & $\begin{array}{c}\text { Justiça } \\
\text { corretiva }\end{array}$ \\
\hline Princípios & 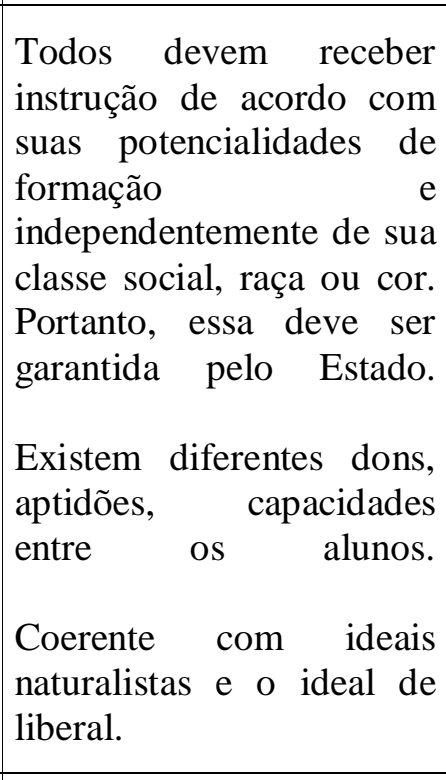 & \begin{tabular}{|lr} 
O ensino oferecido \\
pelas escolas que \\
compõem um mesmo \\
sistema deve ser igual \\
para todos, já que \\
todos têm & igual \\
capacidade & para \\
realizar & as \\
aprendizagens & \\
fundamentais. & \\
& \\
A partir do nível \\
elementar de ensino \\
admitem-se \\
diferenças de dons, \\
potencialidades & ou \\
aptidões naturais. \\
\end{tabular} & 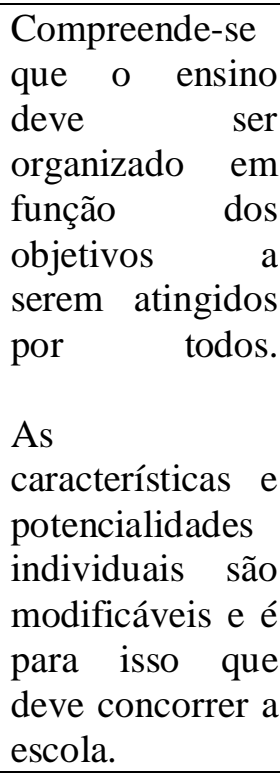 \\
\hline Características & 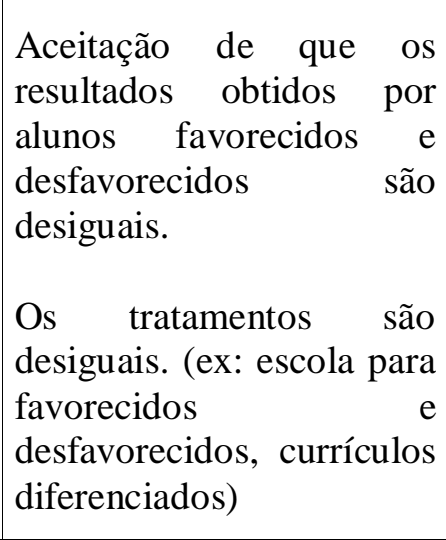 & $\begin{array}{l}\text { Prioriza a } \\
\text { homogeneização das } \\
\text { condições de ensino, } \\
\text { traduzida em } \\
\text { concepções, como } \\
\text { escola única, } \\
\text { currículo comum ou } \\
\text { ensino compreensivo. }\end{array}$ & $\begin{array}{l}\text { Concebe-se que } \\
\text { o indivíduo não } \\
\text { tem somente } \\
\text { direito à } \\
\text { igualdade de } \\
\text { oportunidades } \\
\text { e/ou de } \\
\text { tratamento, mas } \\
\text { também à } \\
\text { igualdade de } \\
\text { conhecimentos } \\
\text { de base. }\end{array}$ \\
\hline
\end{tabular}




\begin{tabular}{|c|c|c|c|}
\hline $\begin{array}{l}\text { Exemplos de } \\
\text { ação }\end{array}$ & \begin{tabular}{lrrr} 
Ajuda & financeira & para \\
estudos & a & alunos \\
desfavorecidos & por & meio \\
de & oferecimento & gratuito \\
de & material & escolar, \\
uniformização & & dos \\
recursos & destinados & às \\
escolas, & \multicolumn{2}{c}{ programas } \\
compensatórios & de \\
alimentação & e & saúde \\
atrelados à & frequência à \\
escola & & etc.) \\
Descentralização & dos \\
equipamentos & educativos \\
e de sua gestão. &
\end{tabular} & $\begin{array}{l}\text { Programas de } \\
\text { unificação do ensino e } \\
\text { do currículo (adoção } \\
\text { de manuais, } \\
\text { programas e planos de } \\
\text { estudo, ações de } \\
\text { formação de docentes } \\
\text { e supervisão de } \\
\text { escolas). }\end{array}$ & $\begin{array}{l}\text { Ações de } \\
\text { discriminação } \\
\text { positiva, } \\
\text { avaliação } \\
\text { formativa, } \\
\text { diferenciação de } \\
\text { ensino e } \\
\text { dispositivos de } \\
\text { apoio que visem } \\
\text { reduzir } \\
\text { desigualdades } \\
\text { iniciais. }\end{array}$ \\
\hline Críticas & $\begin{array}{l}\text { Transformação nos } \\
\text { processos de seleção dos } \\
\text { alunos e de sua orientação } \\
\text { no interior do sistema } \\
\text { escolar. } \\
\text { Práticas de avaliação que } \\
\text { acirram as desigualdades. } \\
\text { Ênfase no mérito como } \\
\text { definidor de acesso os } \\
\text { níveis e áreas mais } \\
\text { avançados de estudos. }\end{array}$ & $\begin{array}{lr}\text { Os resultados obtidos } \\
\text { são } & \text { desiguais. } \\
\text { Rompimento r } & \text { com } \\
\text { princípios } & \text { de } \\
\text { autonomia } & \\
\text { pedagógica } & \text { dos } \\
\text { estabelecimentos } & \\
\text { escolares. } & \\
\text { Não contempla } & \text { as } \\
\text { desigualdades } & \text { iniciais } \\
\text { e, portanto, sem ações } \\
\text { direcionadas rara } \\
\text { minimizá-las, acaba } \\
\text { perenizando-as. }\end{array}$ & $\begin{array}{l}\text { Respeito pela } \\
\text { diversidade e } \\
\text { efeitos perversos } \\
\text { do nivelamento. } \\
\text { EfeitoRobin } \\
\text { Hood. }\end{array}$ \\
\hline
\end{tabular}

Fonte: Oliveira et al. (2013)

Em linha com esta abordagem, o presenteestudo assume que a justiça na educação combina essas três concepções de igualdade com o conceito de eficácia (BROOKE e SOARES, 2008).

De forma sucinta, a eficácia pode ser definida como a capacidade do sistema educacional e/ou da escola em fazer com que todos os alunos aprendam mais do que o esperado, agregando algum valor ao desempenho dos estudantes e melhorando a média dos resultados escolares medidos pelas avaliações (MORTIMORE, 1991, apud BROOKE E SOARES, 2008).

Assim, uma escola que se pretende justa precisa, necessariamente, ser eficaz e igualitária. Em outras palavras, para ser justa, a escola precisa lançar mão 
de ações pedagógicas que garantam o aprendizado e a máxima igualdade de conhecimento entre os alunos, de forma a tornar a variação dos resultados escolares a menor possível. Para isso, a escola deve nortear suas ações ancorandose nos princípios da igualdade de oportunidade, de tratamento e, principalmente, de conhecimento.

\subsection{Categorias de análise da igualdade}

Mensurar a desigualdade de um sistema educativo não é uma tarefa fácil. Waltenberg (2002) questiona quais são os tipos de desigualdades educativas consideradas injustas e inaceitáveis e que devem ser combatidas e quais são as desigualdades que podem ser aceitáveis ou, até mesmo, desejáveis.

Por exemplo, a desigualdade de acesso à educação é uma desigualdade aceitável? Atualmente, há um consenso global de que é injusto que uma parcela da população não tenha acesso ao Ensino Fundamental. $\mathrm{O}$ acesso ao Ensino Médio também é um objetivo considerado justo pela sociedade. Mas, e com relação ao acesso ao nível superior? Não há um consenso, por parte da sociedade, de que o acesso à universidade deva ser universalizado. Hoje, em todos os países do mundo, apenas uma parcela pequena da sociedade consegue ter acesso a esse nível de ensino. No Brasil, apenas 1/5 da população da faixa etária dos 18 aos 25 anos chega à universidade. Então, porque é aceitável a desigualdade de acesso ao ensino superior, enquanto nos níveis fundamental e médio a desigualdade de acesso não é aceitável? Que parte da população deve chegar à universidade? Como determinar essa população?

E sobre a aceitação da desigualdade de tratamento? Diante da lei, todos são iguais e, por isso, é legítimo que todos os indivíduos recebam o mesmo tratamento, o que, na educação, pode ser compreendido como um mesmo nível de recursos escolares. Mas, tratar de maneira igual indivíduos com perfis socioeconômicos diferentes é justo? Waltenberg (2002, p. 112) questiona e afirma:

Não seria mais justo dedicar mais tempo e atenção aos alunos que mais necessitam de auxílio no aprendizado? Economistas (Levi, 1992) e educadores (Crahay, 1997), por exemplo, 
afirmam que cada vez mais se reconhece que a igualdade de acesso ao ensino e ao tratamento (financiamento, gasto com aluno) - ou seja, a justiça igualitária - é apenas uma condição necessária, mas não suficiente, para se atingir a equidade nos resultados escolares.

Como dito anteriormente, para se atingir a igualdade, em termos de resultados escolares, é preciso garantir o aprendizado dos conhecimentos de base a todos os alunos, sem exceção e, por isso, deve-se dar uma atenção suplementar aos alunos com resultados insatisfatórios para que eles consigam adquirir os conhecimentos mínimos requeridos (CRAHAY, 2002).

A luta pela igualdade de resultados escolares extrapola a concepção de justiça igualitária e meritocrática e se alinha à concepção de justiça compensatória, pois compreende que é necessário compensar as deficiências/dificuldades dos indivíduos a fim de assegurar que todos - alunos bons e alunos fracos - adquiram os conhecimentos de base. Isto implica numa distribuição desigual de recursos entre os indivíduos, de forma a privilegiar os mais necessitados sem prejudicar os alunos mais talentosos e/ou mais bemdotados de capital social.

Assim, são várias as definições de desigualdade educacional e por isso existem diferentes abordagens metodológicas para mensurá-la. Não existe, segundo Waltenberg (2002), um consenso sobre a melhor metodologia. Em razão disso, apresenta um quadro que associa a definição de desigualdade aos possíveis indicadores educacionais observáveis. A partir dessa associação, o quadro 4 apresenta as variáveis geralmente utilizadas para tratar do tema da desigualdade.

\section{Quadro 4: Conceitos de desigualdade, possíveis indicadores e variáveis do estudo}

\begin{tabular}{|l|l|r|}
\hline Desigualdade de... & \multicolumn{1}{|c|}{ Possíveis indicadores } & Variáveis do estudo \\
\hline $\begin{array}{l}\text { Desigualdade de } \\
\text { acesso a } \\
\text { determinados } \\
\text { níveis de educação }\end{array}$ & $\begin{array}{l}\text { Porcentagem de indivíduos, ou grupo } \\
\text { de indivíduos, de coortes relevantes } \\
\text { matriculados em determinado nível de } \\
\text { ensino. Ex: porcentagem de crianças } \\
\text { de 6 a 14 anos matriculado no EF, } \\
\text { segundo raça, gênero, nível de renda } \\
\text { etc. }\end{array}$ & $\begin{array}{r}\text { *Taxas de matrículas } \\
\text { bruta e líquida da rede } \\
\text { de ensino. }\end{array}$ \\
\hline
\end{tabular}




\begin{tabular}{|c|c|c|c|}
\hline & $\begin{array}{l}\text { Desigualdade de } \\
\text { tratamento }\end{array}$ & $\begin{array}{l}\text { Diferenciais de gastos por aluno, } \\
\text { segundo localidades ou segundo } \\
\text { sistemas de ensino (Ex: público X } \\
\text { privado). Diferenciais de resultados } \\
\text { de grupos de alunos com a mesma } \\
\text { educabilidade (Ex: homens X } \\
\text { mulheres) }\end{array}$ & $\begin{array}{l}\text { *Rede de ensino } \\
\text { *Gênero } \\
\text { *Raça } \\
\text { *NSE }\end{array}$ \\
\hline$\underset{d}{d}$ & $\begin{array}{l}\text { Desigualdade de } \\
\text { oportunidades }\end{array}$ & $\begin{array}{l}\text { Sensibilidade do desempenho do } \\
\text { aluno ao seu perfil socioeconômico. } \\
\text { Probabilidade de que indivíduos } \\
\text { diferentes (raça, gênero e origem } \\
\text { socioeconômica) atinjam certos } \\
\text { resultados de desempenho. }\end{array}$ & $\begin{array}{c}\text { *Variáveis escolares } \\
\text { (tempo de } \\
\text { aprendizagem, } \\
\text { heterogeneidade e } \\
\text { homogeneidade das } \\
\text { turmas, recursos } \\
\text { pedagógicos, formação } \\
\text { docente, práticas } \\
\text { didático-pedagógicas, } \\
\text { tipo de gestão, currículo } \\
\text { etc.) }\end{array}$ \\
\hline 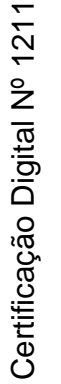 & $\begin{array}{l}\text { Desigualdade de } \\
\text { resultados } \\
\text { escolares }\end{array}$ & 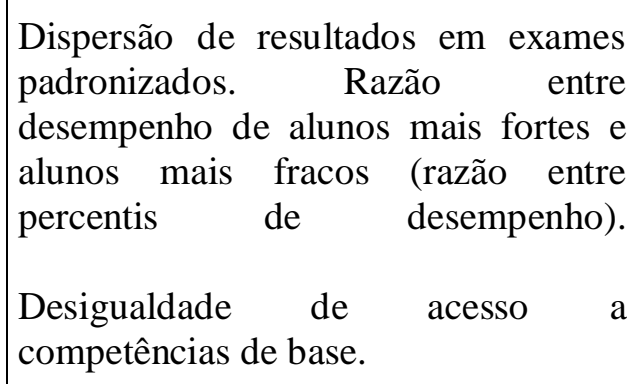 & $\begin{array}{l}\text { *Nível de desempenho } \\
\text { nas avaliações em larga } \\
\text { escalas }\end{array}$ \\
\hline 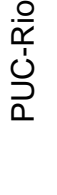 & $\begin{array}{l}\text { Desigualdade de } \\
\text { resultados pós- } \\
\text { escolares }\end{array}$ & $\begin{array}{l}\text { Diferenciais de salários em função do } \\
\text { diploma obtido ou dos anos de estudo } \\
\text { completados (por indivíduos ou } \\
\text { grupos de indivíduos) }\end{array}$ & $\begin{array}{l}\text { *Faixa salarial } \\
\text { *Anos de escolaridade }\end{array}$ \\
\hline
\end{tabular}

Fonte: Waltenberg (2002)

As variáveis referentes aos conceitos de desigualdade de acesso, de tratamento, de oportunidades e de resultados escolares apresentadas no quadro 4 serão utilizadas, junto com o conceito de igualdadede conhecimento de Crahay, na análise dos dados empíricos deste estudo.

\subsection{0 estudo da desigualdade no Brasil}

Desde os anos de 1990 vem se tornando cada vez mais evidente que a escola, e não somente as condições socioeconômicas das famílias, é um fator 
crucial na determinação dos destinos sociais e educacionais dos estudantes. Alguns estudos brasileiros comprovam o papel central da educação na produção das desigualdades sociais, principalmente no que diz respeito às diferenças raciais no mercado de trabalho (BARBOSA, 2011).

Por um lado, há uma discussãoconsolidada sobre a relação entre desigualdade social e desigualdade de ingresso à educação mensurada por indicadores de acesso e de conclusão dos diferentes níveis educacionais. Apesar dessa discussão já estar colocada há algum tempo, ela ainda não foi superada, pois ainda hoje se tem no Brasil uma situação de falta de acesso escolar a determinadas faixas etárias e grupos sociais. Isso pode ser verificado não somente pelos indicadores educacionais, como também pelas metas estipuladas pelo PNE 20142024, na qual nove ${ }^{3}$ delas dizem respeito à garantia do direito à educação básica obrigatória.

Estudos brasileiros mais recentes,que têm procurado investigar a relação entre desigualdades sociais e desigualdade de tratamento e de oportunidades educacionais, procuram tipicamente analisar: 1) a distribuição da oferta de vagas do sistema educacional segundo diferentes grupos sociais - raça, classe social e gênero (desigualdade de tratamento) e 2) as características escolares e seus efeitos na aprendizagem (desigualdade de oportunidades).

\footnotetext{
${ }^{3}$ As nove metas do PNE são:
}

Meta 1: universalizar, até 2016, a educação infantil na pré-escola para as crianças de 4 (quatro) a 5 (cinco) anos de idade e ampliar a oferta de educação infantil em creches, de forma a atender, no mínimo, 50\% (cinquenta por cento) das crianças de até 3 (três) anos até o final da vigência deste PNE. Meta 2: universalizar o Ensino Fundamental de 9 (nove) anos para toda a população de 6 (seis) a 14 (quatorze) anos e garantir que pelo menos $95 \%$ (noventa e cinco por cento) dos alunos concluam essa etapa na idade recomendada, até o último ano de vigência deste PNE. Meta 3: universalizar, até 2016, o atendimento escolar para toda a população de 15 (quinze) a 17 (dezessete) anos e elevar, até o final do período de vigência deste PNE, a taxa líquida de matrículas no Ensino Médio para 85\% (oitenta e cinco por cento). Meta 5: alfabetizar todas as crianças, no máximo, até o final do $3^{\circ}$ (terceiro) ano do Ensino Fundamental. Meta 6: oferecer educação em tempo integral em, no mínimo, $50 \%$ (cinquenta por cento) das escolas públicas, de forma a atender, pelo menos, $25 \%$ (vinte e cinco por cento) dos (as) alunos (as) da educação básica. Meta 7: fomentar a qualidade da educação básica em todas as etapas e modalidades, com melhoria do fluxo escolar e da aprendizagem, de modo a atingir as seguintes médias nacionais para o Ideb: 6,0 nos anos iniciais do Ensino Fundamental; 5,5 nos anos finais do Ensino Fundamental; 5,2 no Ensino Médio. Meta 9: elevar a taxa de alfabetização da população com 15 (quinze) anos ou mais para 93,5\% (noventa e três inteiros e cinco décimos por cento) até 2015 e, até o final da vigência deste PNE, erradicar o analfabetismo absoluto e reduzir em 50\% (cinquenta por cento) a taxa de analfabetismo funcional. Meta 10: oferecer, no mínimo, 25\% (vinte e cinco por cento) das matrículas de educação de jovens e adultos, nos ensinos fundamental e médio, na forma integrada à educação profissional. Meta 11: triplicar as matrículas da educação profissional técnica de nível médio, assegurando a qualidade da oferta e pelo menos $50 \%$ (cinquenta por cento) da expansão no segmento público. 
Os indicadores produzidos com dados do Censo Escolar e também das avaliações em larga escala evidenciam que há uma distribuição desigual,nossistemas de ensino, não somente da oferta de vagas mastambém, de acesso a determinados insumos escolares, como, por exemplo, à biblioteca, laboratórios de informática e ciências, etc.(BARBOSA, 2011;OLIVEIRA et all, 2013; SOARES e ANDRADE, 2006; SOARES, 2006; SOARES e MAROTA, 2008; CARNOY, 2009, entre outros).

Além disso, o PNE traz duas metas que dizem respeito, especifica e respectivamente, à redução das desigualdades e à valorização da diversidade. A existência da desigualdade de tratamento na educação básica brasileira fica clara na meta oito do PNE, que estabelece:

\begin{abstract}
Elevar a escolaridade média da população de 18 (dezoito) a 29 (vinte e nove) anos, de modo a alcançar, no mínimo, 12 (doze) anos de estudo no último ano de vigência deste plano, para as populações do campo, da região de menor escolaridade no país e dos $25 \%$ (vinte e cinco por cento) mais pobres, e igualar a escolaridade média entre negros e não negros declarados à Fundação Instituto Brasileiro de Geografia e Estatística IBGE. (Documento Todos pela educação)
\end{abstract}

Segundo Barbosa (2011), a literatura brasileira sobre a desigualdade de oportunidades educacionais referente aos conhecimentos e métodos didáticos e procedimentos pedagógicos e administrativos das escolas, bem como seus efeitos na aprendizagem, ainda é relativamente escassa. Buscando produzir evidências sobre a desigualdade de oportunidades educacionais, o estudo de Barbosa (2011) investigou 24 escolas públicas de Belo Horizonte entre os anos de 1999 e 2000. A pesquisa utilizou uma abordagem quanti-quali com o objetivo de "aprofundar a definição dos fatores escolares que influenciam diferencialmente os alunos." (BARBOSA, p. 31, 2011), de forma a examinar a escola e os procedimentos administrativos e pedagógicos que, de acordo com pesquisasanteriores, apontaram evidências das características que incidem no desempenho de diferentes grupos sociais. De forma mais específica, a pesquisa investigou o conjunto das formas organizacionais da escola, os métodos e as práticas docentes para o tratamento de classes escolares diferenciadas segundo gênero, etnia e classe social, dando ênfase à atuação docente, por considerá-la um fator crucial na organização escolar. 
Baseando-se na literatura existente sobre os componentes que definem a qualidade da escola, o estudo delineou nove itens (ou características) que conformaram indicadores da qualidade das escolas, explicando que "esses indicadores foram construídos de forma binária, opondo um polo onde encontraríamos características com mais forte propensão a fortalecer a qualidade da escola, e um outro polo onde essas características estariam ausentes ou mais enfraquecidas. " (BARBOSA, 2011, p. 187). Os itens são: 1) O papel do diretor na escola; 2) Expectativa de professores e demais profissionais da escola sobre o desempenho dos alunos; 3) Clima da escola; 4) Existência de objetivos claramente estabelecidos, compreendidos e, principalmente, compartilhados pelos que trabalham na escola; 5) Organização do tempo na escola; 6) Formas e estratégias de acompanhamento do progresso dos alunos, incluindo-se a retro informação para os alunos dos pontos positivos e negativos de seu desempenho, assim como a estratégia planejada para superar as dificuldades; 7) Estratégias de capacitação de professores; 8) Assistência técnica que as instâncias governamentais oferecem às escolas; 9) Participação dos pais, principalmente no momento da realização das tarefas de casa.

O estudo mostrou que o acesso a tais características segundo a renda, o gênero e a cor/raça dos estudantes, de uma maneira geral, é desvantajoso para os alunos de baixa renda e para os alunos pretos.

A segunda etapa do estudo, com abordagem predominantemente quantitativa, analisou as relações entre qualidade, desempenho e posição social, por meio de uma regressão, constatando que a qualidade da escola (definida como o conjunto dos itens acima listados) tem efeitos importantes sobre o desempenho em Matemática ${ }^{4}$ dos alunos. O resultado da regressão mostrou que o peso das diferenças sociais permanece importante, pois os alunos do estrato de renda mais elevado se saem melhor no teste desta disciplina escolar. Nas palavras da autora,

(...) o desempenho dos alunos do estrato de menor renda, nas escolas de boa qualidade, é superior àquele obtido pelos alunos

\footnotetext{
${ }^{4} \mathrm{O}$ modelo de regressão utilizou a média de desempenho em Matemática, porque permite verificar melhor a influência dos fatores escolares, uma vez que o desempenho em linguagem é significativamente afetado pela posição socioeconômica das famílias dos alunos, ao passo que o conhecimento de Matemática é mais clara e fortemente ensinado na escola e, portanto, mais suscetíveis às características das escolas onde as crianças estudam.
} 
do estrato de maior renda, nas escolas de baixa qualidade. É claro que a boa escola melhora o desempenho de todos os seus alunos, inclusive os de maior renda. Mas a parte mais interessante é que ela melhora o desempenho de todos os alunos, independentemente dos efeitos da origem social. A média dos alunos mais pobres nas escolas de boa qualidade é mais elevada que aquela obtida pelo conjunto dos alunos, em qualquer posição social.” (BARBOSA, 2011, p.202)

Essa conclusão reforça o argumento segundo o qual estabelecimentos escolares de boa qualidade melhoram a média de desempenho de seus alunos, não importando a situação econômica dos mesmos. Isso significa que a escola pode ser considerada também um instrumento eficaz de luta contra as desigualdades sociais.

A desigualdade de tratamento e de oportunidades educacionais também foi abordado no estudo de Oliveira et al. (2013), que possui três etapas.

A primeiraparte fez uma extensa revisão da literatura nacional e internacional, apontando as ações pedagógicas que podem ou não influenciar a desigualdade no sistema e na unidade escolar. Essas ações pedagógicas foram divididas em dois grupos: 1) àquelas relacionadas à alocação de recursos e 2) àquelas não relacionadas à alocação dos recursos.

As ações pedagógicas do primeiro grupo dizem respeito ao montante de recursos financeiros e materiais (infraestrutura e materiais escolares) destinado à rede de ensino e às escolas e à maneira como esses recursos são administrados. Os achados de pesquisas mostram que há uma desigualdade na alocação de recursos, pela qual algumas redes de ensino possuem mais recursos que outras. Além disso, dentro de uma mesma rede os recursos nem sempre são distribuídos de forma equânime, levando algumas escolas a terem mais recursos do que outras.

Já as ações pedagógicas do segundo grupo se referem às características das escolas que não dependem da alocação de recursos e dizem respeito:

1) Àquelas já abordadas pela literatura do campo das escolas eficazes: passar e corrigir dever de casa; cumprimento do conteúdo curricular; interesse e dedicação dos professores; nível de exigência docente sobre o desempenho; clima de respeito e disciplina na sala de aula; não absenteísmo docente. 
2) Ao agrupamento das turmas - os critérios que nortearam a distribuição dos alunos nas turmas.

3) À qualidade e distribuição docente - a formação e tempo de experiência dos professores e os critérios que nortearam a escolha dos professores para as turmas pelas quais eles são responsáveis.

4) Ao uso do tempo - a distribuição do tempo entre as diversas atividades escolares propostas pelos professores.

5) A medidas de clima escolar - não há uma única definição sobre o conceito de clima escolar, mas há consenso na literatura de que este é um constructo importante para o alcance de resultados mais equitativos entre os alunos (OLIVEIRA et al., 2013). Há medidas de clima escolar construídas com base no nível de violência da unidade de ensino (SOARES et al., 2012), na ênfase acadêmica da escola, ou seja, a primazia do ensino e da aprendizagem a despeito de outras demandas sociais mais amplas (ALVES e FRANCO, 2008) ou dos sentimentos e atitudes despertados pelo ambiente escolar (LOUKAS, 2007).

6) À busca por envolvimento dos pais - ações promovidas pela escola para maior participação dos pais na vida escolar dos alunos.

A segunda etapa da pesquisa utilizou os resultados de desempenho em Matemática do $5^{\circ}$ ano da Prova Brasil 2009 e os micros dados do Censo Escolar, para a análise estatística das desigualdades educacionais. Para isso, foram criados dois indicadores de desigualdade:

1) Índice de Homogeneidade entre as escolas (IHE) - expressa a proporção da variância das notas do conjunto dos alunos da escola em relação à variância do conjunto das notas de todos os alunos do universo do estudo.

2) Índice de Homogeneidade no interior da escola (IHIE) - expressa a heterogeneidade das notas entre as turmas da escola, ou seja, a razão entre a variância das notas entre as turmas da escola, o que permite perceber a contribuição da turma para a variância total. 
A partir desses dois indicadores,a pesquisa pode observar não apenas a desigualdade entre as escolas, mas também a desigualdade de desempenho intraescolar e observaram que

\begin{abstract}
(...) tanto as escolas que apresentam menor variância de notas em relação ao conjunto (mais homogêneas), quanto as que apresentam maior variação de notas entre as turmas, relativamente à escola, apresentam maior desigualdade. Isso associa melhores resultados a mais desigualdade, o que torna os resultados desejáveis algo contraditório, ou mais complexo de explicitar, posto que não basta aumentar os resultados, pois mesmo nas escolas com maior variabilidade de notas há indícios de segmentação de turmas segundo o desempenho escolar. (OLIVEIRA et al., 2013, p. 95)
\end{abstract}

Esse resultado remete à necessidade de se enfrentar não apenas a elevação da média do desempenho mas também a diminuição da desigualdade desse desempenho entre os estudantes.

A terceira etapa foi a realização de um survey com um plano amostral composto por 390 escolas de São Paulo, 232 no Rio de Janeiro e 378 unidades escolares em todo território nacional, o qual obteve 104 respostas em São Paulo, 50 no Rio de Janeiro e 96 no restante do Brasil (OLIVEIRA et al, 2013, p. 96). A análise dos dados do survey apontaram que a alocação de professores mais bem preparados e experientes em turmas mais desafiadoras e/ou com piores resultados, a ampliação da participação da família nas atividades educacionais e a melhoria do clima acadêmico e disciplinar são ações escolares capazes de reduzir as desigualdades no interior da escola.

Soares e Andrade (2006) também verificaram a existência de uma significativa desigualdade na qualidade das escolas particulares de Belo Horizonte, como indicativo de que a proficiência média superior dessas instituições estaria mais estreitamente relacionada ao nível socioeconômico dos alunos do que à influência da própria escola.Esse estudo utilizou as medidas de desempenho cognitivo dos estudantes das escolas de Belo Horizonte do SIMAVE 2002 e dados do vestibular da UFMG de 2002, 2003 e 2004. Utilizando como metodologia a Teoria da Resposta ao Item (TRI) e os modelos de regressão hierárquicos, o estudo conclui que algumas escolas públicas e privadas conseguem, através de determinadas políticas e práticas pedagógicas, fazer 
diferença no desempenho dos estudantes mesmo quando eles são socioeconomicamente desfavorecidos. Além disso, os autores concluem que $o$ sistema de educação básica de Belo Horizonte só consegue produzir qualidade na presença de alta iniquidade. (SOARES e ANDRADE, 2006, p. 107).

Para Soares e Marotta (2009), a equidade na educação deveria ocorrer quando a distribuição de notas fosse semelhante em todos os grupos definidos de acordo com características sociodemográficas (sexo, raça/cor, nível socioeconomico, etc.). $\mathrm{O}$ estudo realizado pelos autores tomou como unidade de análise alunos agrupados segundo suas características sociodemográficas e, como técnica de análise, a comparação entre as distribuições de desempenho desses grupos. Analisar as diferenças entre alunos pode refletir apenas as escolhas individuais que não são, necessariamente, desigualdades educacionais relevantes. Por outro lado, as diferenças entre as distribuições de desempenho de grupos de alunos indicam sempre desigualdades educacionais, cuja explicação deve ser buscada. Utilizando os dados de Matemática do Saeb 2003 para a oitava série (atual $9^{\circ}$ ano), os autores verificaram que a distribuição de notas dos alunos autodeclarados pretos está mais concentrada nas proficiências mais baixas do que nos demais grupos de cor. Os autores mostram que este resultado é válido também quando se consideram diferentes grupos de nível socioeconômico. Neste caso, alunos com maior status socioeconômico têm a distribuição de suas notas concentrada em valores mais altos do que os demais. Além disso, olhando a série histórica dos dados de desempneho em Leitura e Matemática do Saeb (19952005), os autores sinalizam o aumento da desigualdade educacional do sistema educacional brasileiro.

Já o estudo de Martin Carnoy (2009) utiliza-se de análise de documentos, filmagem das salas de aula e questionários, para comparar as principais características escolares e de sala de aula de três sistemas educacionais latinoamericanos: Brasil, Chile e Cuba. Nesse trabalho, Carnoy aponta a supervisão pedagógica, ou seja, o acompanhamento rigoroso, por parte da direção e/ou equipe pedagógica, do trabalho dos professores (principalmente os novatos), o estabelecimento de um currículo e a seleção/formação inicial e continuada dos professores como possíveis aspectos explicativos da vantagem acadêmica das escolas de Cuba em relação ao Chile e, principalmente, ao Brasil. 
É recorrente, portanto, a associação entre qualidade e fatores escolares destacados pelas pesquisas em eficácia escolar para abordar a desigualdade em termos de variação de acesso às oportunidades escolares pelos diferentes grupos sociais. Para as pesquisas sobre desigualdades educacionais, essas variações reproduzem e, por vezes, acentuam as desigualdades socialmente estruturadas em função da classe socioeconômica, raça/cor e gênero. Outro ponto sobre o qual essas pesquisas chamam a atenção é em relação ao escasso conhecimento disponível acerca dos processos de ensino-aprendizagem que ocorrem dentro da sala de aula e de suas relaçõescom o desempenho dos alunos e com os processos de produção das desigualdades educacionais.

Tomando como referência as três dimensões da igualdade sistematizadas por Crahay (2002) - de oportunidades, de tratamento e de conhecimento - e também as variáveis mais recorrentemente utilizadasna pesquisa educacional para abordá-las, a presente pesquisa focaliza características de escolas públicas do estado do Espírito Santo, para investigar os processos de produção/reprodução de desigualdades educacionais e a forma como as mesmas são engendradas no cotidiano escolar.

A primeira etapa da pesquisa refere-se à análise descritiva e comparativa das desigualdades de oportunidades educacionais baseada em dados referentes ao acesso e ao aprendizado, numa perspectiva macro, que abrange a comparação de indicadores educacionais segundo as regiões geográficas, a localização da escola, a raça/cor dos estudantes e a renda per capita familiar. Essa análise tem por objetivo principal caracterizar a igualdade de tratamento (CRAHAY, 2002, 2013; WALTENBERG, 2002) segundo os diferentes grupos sociais.

A segunda etapa do estudo refere-se à abordagem meso e analisa as desigualdades educacionais entre as turmas escolares, a partir dos dados de desempenho do PAEBES-Alfa - avaliação da alfabetização do estado do Espírito Santo, na perspectiva da análise da noção de igualdade de conhecimento proposta por Crahay.Para a análise da desigualdade entre as turmas, o estudo analisou a média do percentual de acerto dos itens dos testes cognitivos das turmas e das escolas e, também, a variação (desvio-padrão) dessa média. Com essa metodologia, é possível verificar, após controle socioeconomico, se todos os alunos estão adquirindo de forma satisfatória as competências e habilidades 
avaliada pelos itens. Essa análise está associada ao conceito de igualdade de conhecimento, na medida em que investiga a eficácia - observada pelo alto/baixo percentual dos itens - e a igualdade - relacionada à variação do resultado escolar entre as turmas. Essa análise foi feita longitudinalmente, com os itens da avaliação de entrada do $1^{\circ}$ ano e de saída do $3^{\circ}$ ano do Ensino Fundamental capixaba. Complementarmente, o estudo fez a interpretação pedagógica de alguns itens disponibilizados, para verificar o percentual do acerto e sua variação, a habilidade avaliada, seu nível de complexidade e seu padrão de desempenho.

Por fim, na perspectiva micro, e adotando abordagens quantitativa e qualitativa, a pesquisa apresenta a comparação dos resultados obtidos na avaliação do PAEBES-Alfa de quatro escolas e suas respectivas turmas, bem como os achados da pesquisa de campo.Essa etapa foi realizada em quatro escolas: duas no município de Cariacica e duasno município de Serra, por meio de observações e de entrevistas com os professores, coordenadores pedagógicos e diretores.A abordagem qualitativa teve como objetivo investigar a igualdade de oportunidades educacionais (CRAHAY, 2002, 2013; WALTENBERG, 2002), segundo as categorias de análise da literatura.

Com efeito, a partir dos conceitos de desigualdade e das associações com os indicadores e as variáveis já apresentados por Waltenberg, elaborou-se o quadro 5, que sintetiza e associa a análise dos indicadores e das variáveis aos conceitos teóricos já apresentados.

\section{Quadro 5: Tipo de desigualdade, indicadores e variáveis}

\begin{tabular}{|c|c|c|}
\hline $\begin{array}{c}\text { Desigualdade } \\
\text { de... }\end{array}$ & Indicadores & Variáveis \\
\hline $\begin{array}{l}\text { Desigualdade de } \\
\text { acesso } \\
\text { determinados } \\
\text { níveis } \\
\text { educação }\end{array}$ & $\begin{array}{l}\text { Porcentagem de alunos } \\
\text { matriculados nas } \\
\text { diversas etapas da } \\
\text { educação básica: creche } \\
\text { ( } 0 \text { a } 3 \text { anos), pré-escola } \\
\text { (4 e } 5 \text { anos), Ensino } \\
\text { Fundamental (6 aos } 14 \\
\text { anos) e Ensino Médio } \\
\text { (15 aos } 17 \text { anos); }\end{array}$ & $\begin{array}{l}\text { Taxas de matrículas obtidas a } \\
\text { partir dos dados da Pesquisa } \\
\text { Nacional por Amostra de } \\
\text { Domicílios (Pnad). }\end{array}$ \\
\hline Desigualdade de & Diferencial de acesso às & Taxas de matrículas obtidas a \\
\hline
\end{tabular}




\begin{tabular}{|c|c|c|c|}
\hline & tratamento & \begin{tabular}{|lr|}
\multicolumn{2}{|l|}{ diversas etapas da } \\
escolarização & básica \\
segundo & diversos \\
grupos sociais. &
\end{tabular} & $\begin{array}{l}\text { partir dos dados da Pesquisa } \\
\text { Nacional por Amostra de } \\
\text { Domicílios (Pnad), segundo } \\
\text { regiões geográficas, localização, } \\
\text { renda familiar per capita e reça/cor } \\
\text { dos estudantes. }\end{array}$ \\
\hline & $\begin{array}{l}\text { Desigualdade de } \\
\text { resultados } \\
\text { escolares }\end{array}$ & $\begin{array}{l}\text { Distribuição das médias } \\
\text { de desempenho nos } \\
\text { níveis de aprendizado } \\
\text { da ANA (Leitura e } \\
\text { Escrita). } \\
\text { Distribuição da taxa de } \\
\text { distorção idade-série } \\
\text { segundo as redes de } \\
\text { ensino e as regiões } \\
\text { geográficas. } \\
\text { Média e variação do } \\
\text { percentual de acerto dos } \\
\text { itens das avaliações do } \\
\text { PAEBES-Alfa. }\end{array}$ & $\begin{array}{l}\text { Dados de desempenho em Leitura } \\
\text { e Escrita da Avaliação Nacional da } \\
\text { Alfabetização (ANA) } \\
\text { Dados de distorção idade-série } \\
\text { disponibilizados pelo INEP. } \\
\text { Dados de desempenho do } \\
\text { PAEBES-Alfa. }\end{array}$ \\
\hline 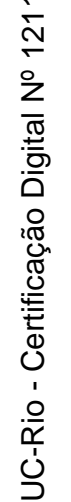 & $\begin{array}{l}\text { Desigualdade de } \\
\text { oportunidades }\end{array}$ & 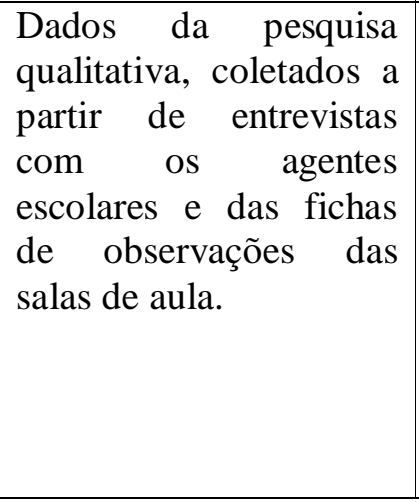 & $\begin{array}{l}\text { Variáveis escolares: dever de casa, } \\
\text { cumprimento do currículo, } \\
\text { sentimento dos professores de } \\
\text { responsabilidade pelo aprendizado, } \\
\text { não abstenteísmo docente, } \\
\text { colaboração docente, organização } \\
\text { das turmas, qualidade (formação) e } \\
\text { distribuição (alocação nas turmas) } \\
\text { docente, uso do tempo, } \\
\text { participação e envolvimento dos } \\
\text { pais. }\end{array}$ \\
\hline
\end{tabular}

O próximo capítulo apresenta o desenho metodológico da pesquisa, bem como o objeto de estudo e as questões que nortearam a pesquisa. 


\section{METODOLOGIA}

As desigualdades educacionais, em termos de resultados escolares tipicamente, podem ser encontradas, no Brasil, entre regiões geográficas, estados da federação, municípios, redes de ensino e escolas da mesma rede, turmas da mesma escola e entre alunos da mesma turma.

As variações nos resultados dos alunos são plausíveis, pois os indivíduos não são iguais entre si e cada um tem características específicas (condição socioeconômica, cor/raça, gênero, disposições cognitivas etc.) que podem explicar, em parte, as diferenças de desempenho escolar. Porém, nos outros níveis, como o da rede de ensino, das escolas e das turmas, essas variações são explicadas não apenas pelas condições socioeconomicas, mas também por outras características que remetem ao tema da relação entre desigualdade social e desigualdade escolar.

As desigualdades nos resultados escolares dos estudantes, em razão das condições socioeconômicas, de raça e de gênero são recorrentemente evidenciadas, no Brasil, por estudos que utilizam dados de avaliações de sistemas de ensino, como a ANEB - Avaliação Nacional da Educação Básica (antigo Saeb), ANRESC - Avaliação Nacional do Rendimento Escolar (Prova Brasil), ANA - Avaliação Nacional da Alfabetização e as diversas avaliações estaduais existentes.

No Brasil, a avaliação educacional se tornou um tema central a partir da década de 1980, no contexto da reforma do Estado, quando este passou a exercer as funções de orientação, coordenação e controle das ações de política educacional. Essas reformas marcaram uma transformação no regime de regulação institucional do Estado, no curso da qual os atores e entidades locais (redes municipais e escolas) passaram a ter mais autonomia na gestão local da oferta educacional e o Estado passou a exercer um papel diferenciado na formulação e na regulação da educação escolar, utilizando-se de novos métodos e instrumentos, que incluem dispositivos de avaliação.

O objetivo desta pesquisa é investigar as desigualdades presentes na educação escolar, utilizando medidas de aprendizado dos alunos de uma das avaliações estaduais que focalizam os anos iniciais do Ensino Fundamental. Mais 
especificamente, este estudo se propõe a utilizar os dados do Programa de Avaliação da Educação Básica do Espírito Santo voltado para a alfabetização (PAEBES-Alfa) para investigar como são produzidas, reproduzidas e geridas, pelas políticas escolares e educacionais, as desigualdades entre as escolas e entre as turmas das escolas.

\subsection{Sobre a alfabetização no Brasil e o PAEBES-Alfa}

Os dados das avaliações em larga escala nacionais - ANEB e ANRESC/Prova Brasil - e das avaliações estaduais realizadas com os alunos do $5^{\circ}$ e do $9^{\circ}$ ano do Ensino Fundamental mostram que há uma grande dificuldade de se alcançar um nível de aprendizado satisfatório para as duas disciplinas avaliadas: Português (com ênfase em Leitura) e Matemática (com ênfase na resolução de problemas).

Os resultados obtidos pelos alunos nessas avaliações são apresentados em pontos, numa escala que é dividida em níveis de desempenho. Cada disciplina tem uma escala. As tabelas 1 e 2 apresentam os níveis de desempenho correspondentes a cada pontuação na escala da ANEB e ANRESC/Prova Brasil para o $5^{\circ}$ ano, respectivamente em Língua Portuguesa e Matemática ${ }^{5}$.

\footnotetext{
${ }^{5}$ Para verificar as habilidades e competências de cada nível de desempenho, consultar: http://download.inep.gov.br/educacao_basica/prova_brasil_saeb/escala/escala_proficiencia/2013/e scalas_ensino_fundamental_2013.pdf
} 
Tabela 1: Nível de desempenho do 50 ano do Ensino Fundamental para Língua Portuguesa (Leitura) - ANEB e ANRESC/Prova Brasil

\begin{tabular}{|c|c|c|}
\hline Nível & Pontuação & $\begin{array}{c}\text { Nível de } \\
\text { desempenho }\end{array}$ \\
\hline Nível 1 & $0-149$ pontos & Insuficiente \\
\hline Nível 2 & $150-174$ pontos & \multirow{2}{*}{ Básico } \\
\hline Nível 3 & 175- 199 pontos & \\
\hline Nível 4 & $200-224$ pontos & \multirow{2}{*}{ Proficiente } \\
\hline Nível 5 & $225-249$ pontos & \\
\hline Nível 6 & $250-274$ pontos & \multirow{4}{*}{ Avançado } \\
\hline Nível 7 & $275-299$ pontos & \\
\hline Nível 8 & $300-324$ pontos & \\
\hline Nível 9 & $325-350$ pontos & \\
\hline
\end{tabular}

Tabela 2: Níveis de desempenho do $5^{\circ}$ ano do Esnino Fundamental para Matemática - ANEB e ANRESC/Prova Brasil

\begin{tabular}{ccc}
\hline Nível & Pontuação & $\begin{array}{c}\text { Nível de } \\
\text { desempenho }\end{array}$ \\
\hline Nível 1 & $125-149$ pontos & Insuficiente \\
Nível 2 & $150-174$ pontos & \\
Nível 3 & $175-199$ pontos & Básico \\
Nível 4 & $200-224$ pontos & \\
Nível 5 & $225-249$ pontos & Proficiente \\
Nível 6 & $250-274$ pontos & \\
Nível 7 & $275-299$ pontos & \\
Nível 8 & $300-324$ pontos & Avançado \\
Nível 9 & $325-350$ pontos & \\
\hline \multicolumn{2}{l}{ Fonte: Elaboração própria a partir dos dados do } \\
site QEdu
\end{tabular}

Os alunos do $5^{\circ}$ ano do Ensino Fundamental que possuem um nível de aprendizado considerado adequado são aqueles que conseguiram alcançar média de desempenho correspondente aos níveis proficiente e avançado.

De acordo com esta definição, no ano de 2013 , apenas $40 \%$ e $35 \%$ dos alunos conseguiram alcançar um aprendizado adequado, respectivamente, em Português e Matemática. Este percentual, considerado insatisfatório, está relacionado à aprendizagem insuficiente dos alunos nos anos anteriores ao $5^{\circ}$ ano. 
A falta de um diagnóstico sobre o momento e a natureza das dificuldades encontradas por professores e alunos na aprendizagem das habilidades básicas deve-se, em parte, à ausência de testes nos anos anteriores ao $5^{\circ}$ ano e está na origem das avaliações da alfabetização implementadas nos estados de Minas Gerais, Ceará e Espírito Santo, bem comono Estudo Longitudinal da Geração Escolar 2005 - Geres ${ }^{6}$.

A compreensão de que os resultados insatisfatórios dos alunos são decorrentes de uma defasagem acumulada de conhecimentos e habilidades desde o início da alfabetização, vem levando o governo federal, estados e municípios a adotar uma série de medidas. Uma das iniciativas foi a ampliação da duração do Ensino Fundamental para nove anos, o que implicou no ingresso dos alunos na escola aos seis anos de idade e na ênfase dos três primeiros anos escolares na alfabetização (Lei no. 11.274/06). Essa iniciativa se reflete na meta 2 do documento Plano de Metas Compromisso Todos pela Educação ${ }^{7}$ elaborado pelo MEC, que estabelece que, até o ano de 2022, todas as crianças deverão estar plenamente alfabetizadas até os oito anos de idade.

Nessa mesma perspectiva está a criação do PNAIC - Pacto Nacional pela Alfabetização na Idade Certa -, um compromisso formal, assumido pelos municípios, estados, distrito federal e governo federal para a garantia da alfabetização de todas as crianças até os oito anos de idade, quando estas devem estar concluindo o $3^{\circ}$ ano do Ensino Fundamental.

Paralelamente às ações governamentais, a sociedade civil organizada fundou em 2006 o Movimento Todos pela Educação (TPE) - Organização da Sociedade Civil de Interesse Público (Oscip) -, que tem como missão contribuir

${ }^{6}$ O Geres acompanhou, entre 2005 e 2008, uma coorte de alunos a partir do primeiro ano de escolarização (alunos com sete anos de idade) em mais de trezentas escolas públicas e privadas de cinco cidades brasileiras. Em cada onda de coleta de dados, os alunos foram testados em Leitura e Matemática e, em diferentes momentos, os professores, os diretores e os pais dos alunos responderam questionários com variáveis destinadas a analisar o impacto dos fatores familiares e escolares nos resultados dos alunos. Mediante o acompanhamento do ritmo e sequência daaprendizagem, a pesquisa GERES visou identificar as características escolares que maximizam a aprendizagem dos alunos e que minimizam o impacto da origem social sobre o aprendizado.

${ }^{7}$ O Plano de Metas Compromisso Todos pela Educação é a conjugação dos esforços da União, Estados, Distrito Federal e Municípios, em regime de colaboração, das famílias e da comunidade, em proveito da melhoria da qualidade da educação básica. Os sistemas municipais e estaduais que aderirem ao Compromisso seguirão 28 diretrizes pautadas em resultados de avaliação de qualidade e de rendimento dos estudantes. 
para que até 2022 (ano do bicentenário da Independência do Brasil), o país assegure a todas as crianças e jovens o direito a uma educação básica de qualidade. O TPE se autodefine como apartidário e plural e aglutina representantes de diferentes setores da sociedade civil, como gestores públicos, educadores, pais, alunos, pesquisadores, profissionais de imprensa, empresários e organizações sociais em torno do compromisso com a "garantia do direito à educação básica de qualidade". Seu principal objetivo declarado é ajudar a propiciar as condições de acesso, de alfabetização e de sucesso escolar. Para isso, foram criadas 5 metas que procuram traduzir o que na ótica do TPE seria necessário fazer para conquistar o direito a uma educação básica de qualidade para todas crianças e jovens. As cinco metas são: Meta 1: Toda criança e jovem de 4 a 17 anos na escola; Meta 2: Toda criança plenamente alfabetizada até os 8 anos de idade; Meta 3: Todos os alunos com aprendizado adequado ao seu ano escolar; Meta 4: Todo jovem com Ensino Médio concluído até os 19 anos; Meta 5: Investimento em educação ampliado e bem gerido.

Além dessas metas, o TPE desenvolveu o Observatório $\mathrm{PNE}^{8}$, uma plataforma online que apresenta as 20 metas do Plano Nacional de Educação (Lei $\mathrm{n}^{\mathrm{o}} 13.005$, de 25 de junho de 2014), as ações implementadas para se alcançar essas metas e os resultados já obtidos.

Uma das ações do governo federal referentes especificamente à alfabetização, foi a implemenação da ANA - Avaliação Nacional da Alfabetização, precedida pela Prova ABC - Prova Brasileira do Final do Ciclo de

\footnotetext{
${ }^{8}$ O Observatório do PNE é uma plataforma online que tem como objetivo monitorar os indicadores referentes a cada uma das 20 metas do Plano Nacional de Educação (PNE) e de suas respectivas estratégias, e oferecer análises sobre as políticas públicas educacionais já existentes e que serão implementadas ao longo dos dez anos de vigência do Plano. A ideia é que a ferramenta possa apoiar gestores públicos, educadores e pesquisadores, mas especialmente ser um instrumento à disposição da sociedade para que qualquer cidadão brasileiro possa acompanhar o cumprimento das metas estabelecidas. A iniciativa é de vinte organizações ligadas à Educação especializadas nas diferentes etapas e modalidades de ensino que, juntas, vão realizar o acompanhamento permanente das metas e estratégias do PNE. São elas: Capes, Cenpec, Comunidade Educativa Cedac, Fundação Itaú Social, Fundação Lemann, Fundação Maria Cecilia Souto Vidigal, Fundação Roberto Marinho/Canal Futura, Fundação Santillana, Fundação Victor Civita, Instituto Avisa Lá, Instituto Natura, Instituto Paulo Montenegro, Instituto Rodrigo Mendes, Instituto Unibanco, Ipea, Mais Diferenças, SBPC, Todos Pela Educação, UNESCO e Unicef. O desenvolvimento da plataforma contou com o apoio do BID. Com a coordenação do Todos Pela Educação, o Observatório do PNE reúne análises e indicadores das metas e estratégias previstas no Plano e um extenso acervo de estudos, pesquisas e notícias relacionados aos temas educacionais por ele contemplados. Além disso, o leitor também terá acesso a informações sobre programas e políticas públicas já em vigor para cada etapa da Educação.
} 
Alfabetização. Criada em 2011, a partir de uma parceria do Inep com o Movimento Todos Pela Educação, o Instituto Paulo Montenegro/Ibope e a Fundação Cesgranrio a Prova ABC aplicou testes de Leitura, Escrita e Matemática a cerca de 6 mil alunos de escolas municipais, estaduais e particulares concluintes do $3^{\circ}$ ano do Ensino Fundamental. Sua segunda aplicação foi realizada no fim de 2012 e contou com a participação de 54 mil alunos dos $2^{\circ}$ e $3^{\circ}$ anos em escolas públicas e privadas de 600 municípios. A Prova $\mathrm{ABC}$ se caracteriza por ser um projeto piloto que deu subsídios para a implantação, em nível federal, da ANA, aplicada pela primeira vez em 2013 a todos os estudantes do $3^{\circ}$ ano do Ensino Fundamental da rede pública brasileira.

A avaliação da alfabetização em âmbito nacional é composta por dois instrumentos, aplicados concomitantemente: 1) questionário contextual voltado aos professores e gestores das escolas que atendem o Ciclo de Alfabetização, com o objetivo de coletar informações sobre as condições de infraestrutura, formação de professores, gestão da unidade escolar, organização do trabalho pedagógico, entre outras; 2) testes de desempenho para os alunos matriculados no $3^{\circ}$ ano, para aferir os níveis de alfabetização e letramento em Língua Portuguesa e Matemática. Esses testes são compostos por vinte itens, cada um. No caso de Língua Portuguesa, são dezessete itens objetivo, de múltipla escolha e três itens de produção Escrita. No caso de Matemática, foram vinte itens objetivos, de múltipla escolha.

Os resultados de desempenho nas áreas avaliadas são expressos em escalas de desempenho de Leitura (Língua Portuguesa) e de Matemática que são compostas por quatro níveis progressivos e cumulativos, organizados do menor para o maior desempenho. Assim, "quando um percentual de alunos foi posicionado em determinado nível da escala, pode-se pressupor que, além de terem desenvolvido as habilidades referentes a este nível, provavelmente também desenvolveram as habilidades referentes aos níveis anteriores". (NOTA EXPLICATIVA - ANA 2013 - MEC/INEP, p. 1). A escala de desempenho de Escrita (Língua Portuguesa) é composta por cinco níveis e também pressupõe a progressão da aprendizagem de um nível para outro. $\mathrm{O}$ anexo 1 apresenta os níveis de desempenho de cada disciplina (Leitura, Escrita e Matemática) e as habilidades e competências que os alunos adquirem em cada nível. 
Como dito anteriormente, Minas Gerais, Ceará e Espírito Santo são estados que possuem suas próprias avaliações da alfabetização. Devido às limitações do Saeb e da Prova Brasil já apontadas, esses estados desenvolveram seus sistemas de avaliação com o objetivo de produzir informações mais detalhadas sobre as redes de ensino estaduais e municipais e sobre cada escola. São avaliações anteriores à ANA, que além de avaliar os mesmos anos escolares que a ANEB e a ANRESC/Prova Brasil, avaliam também os anos iniciais do Ensino Fundamental, coletando informações sobre a alfabetização.

O Espírito Santo implantou seu sistema de avaliação da alfabetização em 2008, por meio do PAEBES-Alfa. Trata-se de uma avaliação que aplica testes de Leitura, Escrita e Matemática aos alunos dos três primeiros anos do Ensino Fundamental. Além dos testes cognitivos para a coleta dos dados de desempenho, o PAEBES-Alfa possui três instrumentos fundamentais para a compreensão dos resultados. O primeiro é a matriz de referência (anexo 2) que apresenta o objetivo a ser alcançado nos testes, ou seja, informa as habilidades que se espera que os alunos alcancem nos diversos níveis de complexidade em cada área do conhecimento. O segundo é a escala de desempenho, estruturada em uma régua de 0 a 1000 pontos e dividida em níveis de desempenho: abaixo do básico, básico, proficiente e avançado. Cada nível possui uma interpretação pedagógica com a descrição das habilidades adquiridas pelos alunos que alcançaram aquela pontuação na escala. $\mathrm{O}$ anexo 3 apresenta a interpretação pedagógica da escala de desempenho do PAEBES-Alfa para Leitura e Escrita em cada ano escolar. E, por último, tem-se os questionários contextuais que são preenchidos pelos pais, professores e diretores e cuja finalidade é coletar informações sobre os alunos, as práticas didático-pedagógicas, a gestão escolar e demais características das escolas. Com essas informações torna-se possível compreender com profundidade a diversidade da realidade escolar, suas práticas didático-pedagógicas e suas formas de gestão.

O PAEBES-Alfa se diferencia das avaliações dos demais estados por apresentar duas inovações que oferecem dados mais precisos sobre as redes de ensino, as escolas e os alunos. A primeira inovação refere-se à inclusão de itens de Escrita nas provas aplicadas aos alunos. Uma vez que a alfabetização é um processo que envolve aprender a ler (decodificação) e a escrever (codificação) 
(SOARES 1999, 2003), a avaliação da Escrita é fundamental para se verificar se as crianças estão sendo plenamente alfabetizadas. As demais avaliações estaduais da alfabetização caracterizam-se por avaliar os alunos apenas em Leitura. Além disso, o PAEBES-Alfa tem um desenho longitudinal, que permite verificar a evolução do aprendizado dos alunos ao longo dos três anos do ciclo de alfabetização e o valor agregado ao desempenho dos alunos ao longo desse período.

São essas duas inovações que justificam a escolhadesta avaliação da alfabetização para a investigação do tema das desigualdades entre as escolas e dentro das escolas nos anos iniciais do Ensino Fundamental.

\subsection{0bjetivo, questões de estudo e metodologia}

Considerando que a promoção da eficácia e da igualdade escolar é uma preocupação presente na elaboração das políticas educacionais e que o foco atual das ações é a alfabetização, este trabalho tem como objetivo identificar as características escolares que contribuem para a diminuição/amplificação das desigualdades educacionais entre as escolas e dentro das escolas. Nesse sentido, se alinha à tradição de pesquisa em eficácia escolar, segundo a qual a escola é capaz de interferir no desempenho dos seus alunos e diminuir ou suprimir os efeitos das condições socioeconomicas. Ou seja, uma escola eficaz é aquela que acrescenta algum "valor extra" aos resultados dos alunos em comparação com outras escolas com um corpo discente semelhante. (BROOKE, 2010, verbete 262 - eficácia escolar.)

Para a realização do estudo, optou-se por analisar as desigualdades em três níveis.

\section{Nível macro}

Analisam-se as desigualdades educacionais a partir de três indicadores relacionados às dimensões das desigualdades de oportunidades: o acesso e o aprendizado. Foram utilizados dados de taxa de matrícula da educação básica, o percentual de alunos com aprendizado adequado no $3^{\circ}$ ano do Ensino Fundamental - ano escolar em que as crianças devem estar plenamente 
alfabetizadas, segundo as metas estabelecidas no PNE, no PNAIC, no Plano de Metas Compromisso Todos pela Educação e na meta 3 do Movimento Todos pela Educação (TPE), e a taxa de distorção idade série, uma vez que o conceito de qualidade adotado pelo MEC engloba não apenas a aprendizagem mas também o fluxo escolar. Dito de outra forma, a qualidade da educação pressupõe que o aluno aprenda e passe de ano. É essa definição de qualidade que está presente no cálculo do Índice de Desenvolvimento da Educação Básica - IDEB, principal instrumento de regulação da qualidade da educação. Os indicadores analisados no nível macro dizem respeito à igualdade de oportunidades (acesso ao sistema escolar) e à igualdade de tratamento (o acesso segundo diferentes grupos sociais e localidades). Tais indicadores não abarcam todos os aspectos referentes à igualdade de oportunidades, uma vez que não levam em consideração o acesso às práticas pedagógicas eficazes. O acesso a tais práticas - apontadas pela literatura sobre eficácia escolar - será abordado no nível micro de análise. As perguntas que nortearam a análise do nível macro foram:

1) Qual é a taxa de matrícula de cada etapa da educação básica? O acesso à educação compulasória já está plenamente garantido? Como se dá a distribuição das taxas de matrículas segundo as regiões geográficas, a localização da escola (urbana/rural), a raça/cor dos estudantes e a renda familiar per capita?

2) Qual é o percentual de alunos do $3^{\circ}$ ano do Ensino Fundamental com aprendizado considerado adequado em Leitura, Escrita e Matemática? Como se dá essa distribuição segundo as regiões geográficas e segundo os níveis de aprendizado?

3) Qual é a taxa de distorção idade-série dos anos iniciais do Ensino Fundamental? Como se dá a distribuição desse indicador segundo as regiões geográficas e as redes de ensino (público e privada)?

Nesse nível de análise, o estudo utilizou os dados do Censo Escolar e da ANA referentes ao Brasil e aos quatro estados da região Sudeste. 


\section{Nível meso}

Com base nos dados longitudinais do PAEBES-Alfa, o estudo observou o percentual médio de acerto dos itens em Leitura ${ }^{9} \mathrm{e}$ a variação desse percentual entre as turmas de uma mesma escola, Para tanto, a escola deveria ter duas turmas ou mais. Os itens analisados referem-se às avaliações de entrada no $1^{\circ}$ ano (2012) e saída no $3^{\circ}$ ano (2014) e cada um deles avalia uma habilidade de Escrita na matriz de referência (anexo 2).

Complementarmente, fez-se a análise pedagógica de doisitens divulgados: quatro do $1^{\circ}$ ano e quatro do $3^{\circ}$ ano. A análise dos itens engloba a verificação de seu percentual médio de acerto, a variação do percentual, o grau de dificuldade, o padrão de desempenho (anexo 3) e a habilidade avaliada.

A análise desses dados está alinhada à perspectiva da igualdade de conhecimento, uma vez que busca averiguar o nível de aprendizagem dos alunos, por meio do percentual de acerto dos itens, após controle das características sociodemográficas, como o status socioeconomico, a raça/cor e o gênero. As principais perguntas que nortearam a análise foram:

1) Qual o nível de desempenho em Leitura e Escrita dos estudantes participantes das quatro ondas de avaliação do PAEBES-Alfa? Qual o ganho de proficiência ao longo dos três anos, após o controle do efeito do nível socioeconômico?

2) As escolas que possuem alto percentual médio de acerto do itens possuem turmas homogêneas ou heterogêneas?

3) O percentual médio de acerto do itens está associado ao seu grau de dificuldade? Ou seja, quanto mais difícil o item for, menor é o seu percentual de acerto?

4) A variação do percentual de acerto do item está associada ao seu grau de dificuldade? Ou seja, quanto mais difícil for o item, mais homogêneas ou heterogêneas são as turmas?

5) Quais são as características dos itens? Qua habilidades eles avaliam? Qual o seu grau de dificuldade? Qual o percentual de

\footnotetext{
${ }^{9}$ Nesse nível de análise, não utilizaram-se os itens de Escrita, pois os dados apresentaram muitas inconsistências.
} 
acerto e a variação dos itens difíceis? Qual seu padrão de desempenho?

A análise do nível meso utiliza os dados do estado do PAEBES-Alfa.

\title{
Nível micro
}

Por fim, no nível micro, a análise foi feita por meio de duas abordagens: 1) Quantitativa, com a finalidade de comparar os resultados e a variação desses resultados entre as quatro escolas e entre suas turmas; 2) Qualitativa visando descrever e analisar os principais fatores que caracterizam essas escolas e turmas.

Autores como Willms (1992); Goldstein (2001) e Mayer (1999) discutem o fato de a explicação do desempenho escolar não se esgotar com as evidências estatísticas. Segundo Soares (2002, p.27),

\begin{abstract}
os sistemas educacionais e as escolas são marcados por uma grande complexidade, que foge a qualquer descrição que se julgue completa e que ultrapassa os limites dos dados estatísticos. Como apontou Bressoux, hoje se torna importante a realização de pesquisas que se voltem para a compreensão dos processos escolares, produzindo-se uma análise do que se passa no interior das escolas, e, dessa maneira, compreendendo-se a escola não como uma unidade de produção, mas como uma organização social.
\end{abstract}

Este estudo realizou, portanto, quatro estudos de caso como complemento às evidências estatísticas e às suas interpretações, articulando à abordagem quantitativa uma abordagem qualitativa que teve como finalidade lançar luz sobre os dados estatísticos produzidos pelo PAEBES-Alfa.

Para a análise do nível micro, colocaram-se as seguintes perguntas:

1) Após controle pelo índice socioeconomico, como se dáa evolução do desempenho médio em Leitura e Escrita das quatros escolas ao longo dos 3 primeiros anos do ciclo de alfabetização? Nesse período, as escolas ficam mais homogêneas ou heterogêneas segundo o desempenho médio? 
2) Após controle pelo índice socioeconomico, como se dá a evolução do desempenho médio em Leitura e Escrita ao longo dos 3 primeiros anos do ciclo de alfabetização das turmas dessas escolas?Nesse período, as turmas ficam mais homogêneas ou heterogêneas segundo o desempenho médio?

3) Como se apresentam, nas escolas e turmas, os principais fatores escolares definidos pela literatura - dever de casa, cumprimento do curriculo, sentimento de responsabilidade pelo aprendizado dos alunos, não absenteísmo docente, colaboração docente, organização das turmas, qualidade docente, participação e envolvimento dos pais nas atividades escolares dos filhos?

Os três níveis de análise são o tema dos próximos capítulos. 


\section{AS DESIGUALDADES NO SISTEMA EDUCACIONAL BRASILEIRO: nível macro de análise}

A escolarização é a principal forma de educação capaz de desenvolver nos indivíduos potencialidades que lhes permitem o "pleno desenvolvimento da pessoa, seu preparo para o exercício da cidadania e sua qualificação para o trabalho", conforme estabelecido no artigo 205 da Constituição Federal de 1988.

Por se tratar de um direito inalienável e subjetivo, deve ser ofertado universalmente de forma a promover as mesmas oportunidades entre os membros de um país. No entanto, em contextos de alta desigualdade social - como o Brasil - a universalidade ainda é um desafio a ser alcançado e, portanto, a oferta de escolarização é pauta prioritária do poder público (COSTA RIBEIRO, 2009). Apesar de avanços importantes na ampliação do acesso a todos os níveis e modalidades educacionais, a baixa escolaridade média da população e a desigualdade de acesso e de qualidade do ensino entre diferentes grupos sociais permanecem, reforçando a necessidade da universalização da oferta da educação básica e a melhoria da qualidade do ensino, bem como a eliminação do analfabetismo - que ainda persiste.

Assim, identificar o nível de desigualdade das condições educacionais dos estudantes brasileiros é importante como forma de contextualizar o grau em que as políticas públicas estão contribuindo para a universalização das oportunidades educacionais, em termos de acesso e de qualidade. Nesse sentido, a abordagem do nível macro das desigualdades irá apresentar os dados referentes à taxa de matrícula (desigualdade de acesso) em cada nível de ensino (creche, pré-escola, Ensino Fundamental e Ensino Médio), bem como os dois indicadores que integram o conceito de qualidade: desempenho e fluxo escolar (INEP/MEC, 2007).

O conceito de qualidade da educação estabelecido pelo MEC leva em consideração não apenas o acesso à escola e o nível de aprendizado dos estudantes, mas também a taxa de aprovação - definida como a proporção de alunos aprovados em cada uma das séries da etapa considerada - do sistema educacional. 
Segundo Correa (2013), a repetência é uma prática escolar de retenção, em uma determinada série, de estudantes que não alcançaram o aprendizado esperado ao final de um ano escolar. O objetivo desta prática seria corrigir possíveis falhas na aprendizagem ou adequar situações de imaturidade do aluno. No entanto, a extensão e a intensidade do uso desta prática por parte das escolas que compõem os sistemas de ensino tem "exercido uma pressão significativa sobre o fluxo e a produtividade das redes, provocando o aumento exagerado das taxas de defasagem idade-série e de evasão." (CORREA, p.13, 2013)

Correa também afirma que apesar dos avanços no que se refere à garantia do acesso da quase totalidade da população da faixa etária de 6 a 17 anos, ainda é preciso garantir o fluxo pelas séries e pelas etapas da educação básica, de forma a garantir sua conclusão no tempo esperado.

Portanto, o desafio posto para a política educacional brasileira é a garantia não apenas do acesso, mas também da aprendizagem e da progressão escolar. Por isso, numa definição sintética, a qualidade do sistema educacional pode ser medida pela sua capacidade de fazer com que os alunos aprendam e passem de ano. É esse o conceito contido na formulação do cálculo do IDEB - principal indicador que mensura a qualidade do sistema educacional.

Neste capítulo, a análise das desigualdades educacionais se baseará nos indicadores de acesso e de qualidade, sempre que possível segundo variáveis sociais clássicas, como o nível socioeconômico e a raça/cor e também segundo as variáveis geográficas:

1) Acesso - observação da taxa de matrícula;

2) Qualidade:

a) Aprendizado (observação do percentual de alunos com aprendizado adequado no $3^{\circ}$ ano do Ensino Fundamental);

b) Fluxo (observação da taxa de distorção idade-série nos anos iniciais do Ensino Fundamental).

O objetivo é investigar, no nível macro, como se configuram as desigualdades das oportunidades de acesso e de qualidade (aprendizagem e fluxo) no sistema educacional brasileiro. 


\subsection{O Brasil e a desigualdade de oportunidades educacionais}

\subsubsection{A desigualdade de acesso}

Desde a década de 1970, o sistema educacional brasileiro vem apresentando uma extensa ampliação da oferta de oportunidades educacionais, especificamente no que se refere ao aumento contínuo e gradual de vagas nas escolas públicas, que, no fianl dos anos de 1990, levou a considerar universalizado o acesso ao Ensino Fundamental entre a população da faixa etária correspondente. Desde então, a oferta de vagas nas outras etapas da educação básica e no nível superior vem aumentando de forma signficativa, embora produzindo também novas exclusões e, portanto, novas desigualdades educacionais. Os diagnósticos que subsidiaram a formulação das metas do Plano Nacional de Educação - PNE 2014/2024, revelam, por exemplo, que ainda há crianças e jovens em idade escolar sem acesso à escola.

Os dados da Tabela $3^{10}$ referem-se ao acesso das crianças de 0 a 3 anos às creches e escolas por região brasileira, localização, raça e renda per capita. Embora a faixa etária analisada não seja legalmente compulsória, o PNE estabeleceu na meta 1 , a ampliação da oferta de educação infantil em creches de forma a atender, no mínimo, 50\% das crianças de até 3 anos até 2024 - ano que finda a vigência do PNE.

No ano de 2013, as escolas e creches brasileiras atendiam a 27,9\% das crianças de 0 a 3 anos, sendo que essa oferta era muito desigual, conforme mostram os dados da Tabela 9. A região Norte atendia apenas a 12,7\% das crianças nessa faixa etária, enquanto o Sul atendia a $35,2 \%$, ou seja, mais que o dobro.

A desigualdade de acesso também pode ser observada na localização das escolas: em 2013, 30,8\% das vagas eram ofertadas em escolas/creches urbanas, enquanto que as escolas/creches rurais atendiam a apenas $13 \%$ da população de 0 a 3 anos. Sobre a distribuição das vagas segundo a raça/cor, 32,6\% das crianças atendidas eram negras e $30,7 \%$ brancas. No que diz respeito ao acesso por renda

\footnotetext{
${ }^{10}$ Os dados estatísticos apresentados neste capítulo foram retirados do site Observatório PNE, de responsabilidade do Movimento Todos pela Educação. Suas informações provém do IBGE/Pnad, MEC/INEP e Censo Escolar
} 
per capita, 47,6\% eram crianças com renda familiar per capita alta (25\% mais ricos), ao passo que esse atendimento incluia apenas $20,4 \%$ das crianças com renda familiar per capita baixa (25\% mais pobres).

Tabela 3: Porcentagem de crianças de 0 a 3 anos na escola - Todas as redes

\begin{tabular}{|c|c|c|c|c|c|c|c|c|c|c|c|c|}
\hline & 2001 & 2002 & 2003 & 2004 & 2005 & 2006 & 2007 & 2008 & 2009 & 2011 & 2012 & 2013 \\
\hline Brasil & 13,8 & 14,9 & 15,5 & 17,3 & 16,7 & 19,6 & 21,4 & 23 & 23,2 & 25,4 & 25,7 & 27,9 \\
\hline Norte & 10,4 & 10,8 & 11,3 & 8,6 & 8,5 & 11,3 & 10,9 & 13 & 12,4 & 12,1 & 11,3 & 12,7 \\
\hline Nordeste & 14,5 & 14,7 & 15,7 & 17 & 16,6 & 18,6 & 19,6 & 20,7 & 21,5 & 22,9 & 23,7 & 25 \\
\hline Sudeste & 15 & 16,5 & 16,7 & 20,2 & 19,5 & 23,6 & 26,7 & 27,5 & 27,7 & 30,8 & 29,8 & 33,1 \\
\hline Sul & 13,5 & 15,5 & 16,8 & 20,2 & 18,2 & 20,6 & 24,1 & 27,2 & 27,2 & 30,6 & 33 & 35,2 \\
\hline $\begin{array}{l}\text { Centro- } \\
\text { Oeste } \\
\text { Localização }\end{array}$ & 8,5 & 10,7 & 10,1 & 11,6 & 12,4 & 14,5 & 15,9 & 18,8 & 18,2 & 18,8 & 22,6 & 21,6 \\
\hline Urbana & 15,5 & 16,8 & 17,4 & 19,9 & 19,2 & 22,2 & 24,2 & 25,8 & 25,5 & 27,9 & 28,2 & 30,8 \\
\hline Rural & 6,3 & 6,4 & 6,9 & 7,3 & 7,2 & 9,2 & 10,2 & 11,4 & 13,1 & 12,7 & 13,4 & 13 \\
\hline Raça/Cor & & & & & & & & & & & & \\
\hline Branco & 14,7 & 16,4 & 16,8 & 19,1 & 18 & 21,2 & 23,6 & 25,5 & 24,8 & 27,8 & 28,8 & 30,7 \\
\hline Preto & 15,3 & 17,4 & 19,5 & 20,7 & 21,9 & 22,7 & 25,4 & 26,1 & 27,1 & 27,6 & 27,7 & 32,6 \\
\hline Pardo & 12,5 & 13 & 13,6 & 14,9 & 14,9 & 17,6 & 18,8 & 20,1 & 21,1 & 22,5 & 22,4 & 24,5 \\
\hline $\begin{array}{l}\text { Renda } \\
\text { Renda } \\
\text { familiar per } \\
\text { capita / } 25 \% \\
\text { mais pobres }\end{array}$ & 10,4 & 10,5 & 11,7 & 12,7 & 12,3 & 14,6 & 15,3 & 16,9 & 17,7 & 18,6 & 18,5 & 20,4 \\
\hline $\begin{array}{l}\text { Renda } \\
\text { familiar per } \\
\text { capita / 25\% } \\
\text { a 50\% }\end{array}$ & 13 & 14,1 & 15,3 & 18 & 18,3 & 22,3 & 23,7 & 25,6 & 25,4 & 27,7 & 27,7 & 31,3 \\
\hline $\begin{array}{l}\text { Renda } \\
\text { familiar per } \\
\text { capita / 50\% } \\
\text { a } 75 \%\end{array}$ & 17,5 & 21,6 & 22,1 & 24,1 & 22,8 & 28,8 & 30,8 & 32,7 & 30,2 & 35,7 & 36,8 & 39,8 \\
\hline $\begin{array}{l}\text { Renda } \\
\text { familiar per } \\
\text { capita / } 25 \% \\
\text { mais ricos }\end{array}$ & 32,6 & 35,7 & 31,8 & 37,1 & 34,6 & 37,5 & 42,1 & 43,3 & 42,8 & 43,1 & 46,6 & 47,6 \\
\hline
\end{tabular}

Fonte: Elaboração própria a partir dos dados do Observatório $\mathrm{PNE}^{11}$

\footnotetext{
${ }^{11}$ Os dados de todas as tabelas apresentadas neste capítulo foram retirados da plataforma online Observatório PNE. O Movimento Todos pela Educação é o criador e o responsável pela manutenção das informações dessa plataforma online. Os dados divulgados são provenientes do IBGE/Pnad e MEC/INEP. Os dados divulgados na plataforma Observatório PNE são da Pesquisa Nacional de Amostra por Domicílio (PNAD), Censo Escolar e INEP.
} 
A ampliação da obrigatoriedade da educação básica, estabelecida pela lei $n^{0} 12.796 / 2013$, incorporou a pré-escola como etapa da educação básica e tornou compulsória a idade de 4 anos para a entrada no sistema educacional. Para atender a esta disposição legal, a meta 1 do PNE estabeleceu a meta de universalização do acesso das crianças de 4 e 5 anos à educação infantil na pré-escola, até 2016.

Os dados da Tabela 4mostram que o aumento da oferta de educação préescolar vem aumentando ao longo do tempo, sendo que, em 2013, 87,9\% das crianças da faixa etária considerada estavam frequentando a escola. No entanto, a distribuição desta oferta não se dá de forma equilibrada, uma vez que, na região Norte, $78,8 \%$ das crianças são atendidas e no Nordeste, esse percentual é de $92,6 \%$.

Quanto à localização, observa-se que as escolas urbanas atendem a 89,1\% e as escolas rurais a $82,4 \%$ das crianças de 4 a 5 anos. Em relação à raça, a distribuição é bastante homogênea. Já quando se considera a renda familiar per capita, tem-se que $95,8 \%$ das crianças atendidas pertencem aos $25 \%$ mais ricos, enquanto $85 \%$ dessas crianças pertencem aos 25\% mais pobres. Assim, mesmo que atenuada ao longo do tempo, a desigualdade no acesso à escola na faixa etária de 4 e 5 anos permanece seja entre as regiões brasileiras, seja entre área rural e urbana, seja entre alunos mais ricos e mais pobres.

Tabela 4: Porcentagem de crianças de 4 a 5 anos na escola - Todas as redes

\begin{tabular}{lcccccccccccc}
\hline & 2001 & 2002 & 2003 & 2004 & 2005 & 2006 & 2007 & 2008 & 2009 & 2011 & 2012 & 2013 \\
\hline Brasil & $\mathbf{6 6 , 4}$ & $\mathbf{6 7 , 6}$ & $\mathbf{6 9 , 7}$ & $\mathbf{7 1 , 8}$ & $\mathbf{7 2 , 5}$ & $\mathbf{7 6 , 7}$ & $\mathbf{7 8 , 9}$ & $\mathbf{8 1 , 1}$ & $\mathbf{8 3}$ & $\mathbf{8 5 , 6}$ & $\mathbf{8 5 , 9}$ & $\mathbf{8 7 , 9}$ \\
Norte & 61,6 & 63,5 & 63,8 & 57,9 & 60,2 & 64,4 & 69,4 & 72,7 & 75,3 & 75,9 & 75 & 78,8 \\
Nordeste & 71,6 & 73,1 & 74,3 & 76,8 & 79,2 & 82 & 84,5 & 86,8 & 88,2 & 90,5 & 90,7 & 92,6 \\
Sudeste & 69,8 & 70,3 & 73,2 & 77,5 & 76,4 & 82 & 83,3 & 84,5 & 87 & 89,6 & 88,4 & 90,5 \\
Sul & 54 & 55,5 & 58,8 & 60,1 & 60,3 & 65 & 66,6 & 70,1 & 70,4 & 75,6 & 80,2 & 80,4 \\
Centro- & & & & & & & & & & & & \\
Oeste & 53,9 & 56,1 & 58,2 & 61,5 & 63,2 & 66,4 & 67,2 & 71,6 & 75,3 & 76,9 & 79,7 & 82,5 \\
Localização & & & & & & & & & & & & \\
Urbana & 70,2 & 71,3 & 73,3 & 76 & 76,6 & 80,3 & 81,8 & 83,8 & 84,9 & 87,3 & 87,4 & 89,1 \\
Rural & 50,7 & 51,2 & 53,4 & 55,2 & 56,9 & 62,5 & 67,2 & 70,4 & 75,1 & 77,9 & 78,8 & 82,4 \\
Raça & & & & & & & & & & & & \\
Branco & 68,9 & 70,6 & 71,8 & 74,3 & 75 & 79,1 & 81,3 & 83,1 & 84,2 & 86,7 & 87,3 & 89,2 \\
Preto & 63,2 & 63,9 & 68 & 70 & 70,2 & 77,2 & 77,6 & 80,1 & 81,1 & 87 & 84,8 & 88,3
\end{tabular}




\begin{tabular}{|c|c|c|c|c|c|c|c|c|c|c|c|c|}
\hline Pardo & 64,2 & 64,6 & 67,8 & 69,4 & 70,3 & 74,5 & 76,8 & 79,5 & 82 & 84,7 & 84,9 & 86,9 \\
\hline $\begin{array}{l}\text { Renda } \\
\text { Renda } \\
\text { familiar per } \\
\text { capita / } 25 \% \\
\text { mais pobres }\end{array}$ & 58,4 & 58,7 & 62,7 & 64,9 & 65,6 & 70,2 & 73,4 & 75,5 & 78,9 & 81,7 & 82,1 & 85 \\
\hline $\begin{array}{l}\text { Renda } \\
\text { familiar per } \\
\text { capita / 25\% } \\
\text { a 50\% }\end{array}$ & 67,2 & 70,4 & 71,3 & 74,2 & 76,2 & 81,1 & 81 & 83,3 & 84,8 & 87 & 87,3 & 88,9 \\
\hline $\begin{array}{l}\text { Renda } \\
\text { familiar per } \\
\text { capita / } 50 \% \\
\text { a } 75 \%\end{array}$ & 76,5 & 78,6 & 79,8 & 81,3 & 82,5 & 86,8 & 88,5 & 90,4 & 90,2 & 92,3 & 90,7 & 92,8 \\
\hline $\begin{array}{l}\text { Renda } \\
\text { familiar per } \\
\text { capita / } 25 \% \\
\text { mais ricos }\end{array}$ & 91,1 & 90,2 & 91,5 & 91,6 & 92 & 93,3 & 92,5 & 94,7 & 93,9 & 95,2 & 96,3 & 95,8 \\
\hline
\end{tabular}

Sobre a oferta de Ensino Fundamental, os dados nacionais apontam que o acesso a esta etapa escolar está praticamente universalizado desde 1998. Apesar disso, essa universalização ainda não alcançou $100 \%$ e sua oferta continua desigual. Segundo informações do Movimento Todos pela Educação,

\begin{abstract}
Cerca de 500 mil crianças de 6 a 14 anos permanecem fora da escola (dados de 2013). Predominam, entre elas, as de famílias mais pobres, com renda per capita de até $1 / 4$ de salário mínimo, negras, indígenas e com deficiência. Portanto, trata-se de um grupo que pede políticas públicas específicas e diferenciadas. (site: www.observatoriodopne.org.br. Acesso em 01/11/2015)
\end{abstract}

Os dados da Tabela $5^{12}$ mostram que o percentual de estudantes da faixa etária de 6 a 14 anos é alto, mas ainda o acesso à escola não é plenamente universal. É por causa dessa quase universalização que a meta 2 do PNE estabelece que, até 2024, o Ensino Fundamental de 9 anos deve estar plenamente universalizado para a população de 6 a 14 anos. Numa clara preocupação com o

\footnotetext{
${ }^{12}$ A Tabela 11 apresenta os dados a partir do ano de 2007, pois foi o ano em que o sistema educacional brasileiro passou a receber os alunos de 6 anos de idade. Até o ano de 2006, os alunos iniciavam sua trajetória escolar no Ensino Fundamental aos 7 anos de idade. A partir da Lei ${ }^{\circ}$ 11.274/2006, que amplia o Ensino Fundamental para 9 anos, os alunos começaram a frequentar esta etapa escolar aos 6 anos de idade.
} 
fluxo escolar, o PNE também estabelece que se deve garantir que pelo menos 95\% dos estudantes concluam esta etapa na idade recomendada.

Os dados evidenciam que a distribuição da oferta se dá de forma mais ou menos homogênea, havendo, em 2013, pouca variação entre as regiões, a localização, a raça/cor e a renda familiar per capita. Apesar da pequena variação, os dados apontam que a taxa de matrícula líquida é menor na região Norte, nas escolas rurais, para os estudantes de cor preta e para aqueles que pertencem a famílias com renda per capita baixa (25\% mais pobres).

Tabela 5: Porcentagem de crianças de 6 a 14 anos na escola - Taxa de matrícula líquida - Todas as redes

\begin{tabular}{lcccccc}
\hline & 2007 & 2008 & 2009 & 2011 & 2012 & 2013 \\
\hline Brasil & $\mathbf{9 5 , 2}$ & $\mathbf{9 6 , 3}$ & $\mathbf{9 6 , 7}$ & $\mathbf{9 7}$ & $\mathbf{9 7}$ & $\mathbf{9 7 , 1}$ \\
Norte & 93,5 & 94,9 & 95,1 & 95,4 & 95,5 & 95,7 \\
Nordeste & 94,7 & 96 & 96,2 & 96,3 & 96,4 & 96,2 \\
Sudeste & 95,7 & 96,6 & 97,3 & 97,6 & 97,7 & 98 \\
Sul & 96,1 & 97 & 97,4 & 97,7 & 97,7 & 98,1 \\
Centro-Oeste & 96 & 96,5 & 97,2 & 97,4 & 97,2 & 97 \\
Localização & & & & & & \\
Urbana & 95,5 & 96,6 & 96,9 & 97,2 & 97,1 & 97,3 \\
Rural & 94 & 95,3 & 96 & 96 & 96,3 & 96,4 \\
Raça & & & & & & \\
$\begin{array}{l}\text { Branco } \\
\text { Preto }\end{array}$ & 96,1 & 97,1 & 97,3 & 97,6 & 97,8 & 97,7 \\
$\begin{array}{l}\text { Pardo } \\
\text { Renda }\end{array}$ & 93,4 & 95,2 & 96,5 & 95,8 & 96,7 & 96,7 \\
Renda familiar per & 94,7 & 96 & 96,4 & 96,6 & 96,5 & 96,8 \\
capita / 25\% mais & 94,2 & 95,6 & 95,9 & 96,2 & 96,3 & 96,5 \\
pobres & & & & & & \\
$\begin{array}{l}\text { Renda familiar per } \\
\text { capita / 25\% a 50\% }\end{array}$ & 95,6 & 96,4 & 97,1 & 97,3 & 97,4 & 97,2 \\
$\begin{array}{l}\text { Renda familiar per } \\
\text { capita / 50\% a 75\% }\end{array}$ & 96,8 & 97,7 & 98,1 & 98,2 & 98 & 98,4 \\
$\begin{array}{l}\text { Renda familiar per } \\
\text { capita / 25\% mais ricos }\end{array}$ & 98,3 & 98,8 & 98,6 & 99 & 98,8 & 99 \\
\hline
\end{tabular}

Fonte: Elaboração própria a partir dos dados do Observatório PNE

O Ensino Médio - última etapa da educação básica - ainda está bem longe de concretizar a universalzação do atendimento à faixa etária correspondente a 
essa etapa do ensino. Segundo a meta 3 do PNE, o atendimento escolar a toda a população de 15 a 17 anos deve se concretizar até o ano de 2016, e até 2024 a taxa de matrícula líquida do Ensino Médio deve atingir o percentual de 85\%. Ou seja, o acesso ao Ensino Médio ainda é tão precário que a meta estabelecida pelo PNE para 2024 sequer prevê à sua universalização para a população da faixa etária correspondente.

Os dados da Tabela 6mostram que, em 2013, a taxa de matrícula líquida no Ensino Médio era de 59,5\%, sendo que a distribuição da oferta é desigual entre as regiões: o Norte possui a menor taxa de matrícula líquida - 49,2\%, apenas enquanto no Sudeste, essa taxa é de $67,8 \%$.

A desigualdade de acesso ao Ensino Médio, na população de 15 a 17 anos, também se configura entre escolas urbanas e rurais, que atendem, respectivamente, $62,1 \%$ e 47,2\% da matrícula líquida. As iniquidades também são observadas em relação à raça/cor dos estudantes que apresenta taxas de atendimento de $68,4 \%$ para os brancos e de $50,5 \%$ para os pretos.

Por fim, a maior desigualdade de acesso está associada à renda familiar dos alunos, com atendimento de apenas 48,3\% dos alunos de famílias com renda per capita baixa ( $25 \%$ mais pobres) e de $85,6 \%$ dos alunos com renda familiar per capita alta (25\% mais ricos).

\section{Tabela 6: Porcentagem de crianças de 15 a 17 anos na escola - Taxa de} matrícula líquida - Todas as redes

\begin{tabular}{lcccccccccccc}
\hline & 2001 & 2002 & 2003 & 2004 & 2005 & 2006 & 2007 & 2008 & 2009 & 2011 & 2012 & 2013 \\
\hline Brasil & $\mathbf{4 0 , 3}$ & $\mathbf{4 2 , 7}$ & $\mathbf{4 6 , 8}$ & $\mathbf{4 7 , 5}$ & $\mathbf{4 8 , 7}$ & $\mathbf{5 0 , 3}$ & $\mathbf{5 1 , 6}$ & $\mathbf{5 4}$ & $\mathbf{5 4 , 5}$ & $\mathbf{5 6 , 1}$ & $\mathbf{5 7 , 9}$ & $\mathbf{5 9 , 5}$ \\
Norte & 30,6 & 33,4 & 37,4 & 30,9 & 33,6 & 37,5 & 40,2 & 42,4 & 42,7 & 45,9 & 47,3 & 49,2 \\
Nordeste & 23,5 & 25,4 & 29,1 & 31,1 & 33,5 & 36,5 & 38,6 & 40,3 & 43 & 47,5 & 48,8 & 51,1 \\
Sudeste & 52,2 & 55,7 & 60,3 & 61,8 & 61,9 & 62,2 & 63,5 & 65,6 & 64,5 & 64,2 & 67 & 67,8 \\
Sul & 50,3 & 52,4 & 54,7 & 56,6 & 56,6 & 56,5 & 56,5 & 59 & 59,9 & 58,7 & 59 & 62,1 \\
Centro- & & & & & & & & & & & & \\
Oeste & 40,1 & 43,5 & 47 & 49 & 49 & 51,3 & 53 & 56,1 & 58,7 & 62,1 & 63,3 & 62,1 \\
Localização & & & & & & & & & & & & \\
Urbana & 44,8 & 47,7 & 51,8 & 53,2 & 54,2 & 55,4 & 56,3 & 58,4 & 58,4 & 59,4 & 60,9 & 62,1 \\
Rural & 19,3 & 19,9 & 23,8 & 23,7 & 27,6 & 29,4 & 33,3 & 35,5 & 38,1 & 41,3 & 43,7 & 47,2 \\
Raça & & & & & & & & & & & & \\
Branco & 53,4 & 54,7 & 58,6 & 59,7 & 60,3 & 61,5 & 62,8 & 64,8 & 64,3 & 64,4 & 67,7 & 68,4 \\
Preto & 24,2 & 31,2 & 36,5 & 37,7 & 39,9 & 39,9 & 44,5 & 49 & 46,7 & 47,2 & 47,7 & 50,5
\end{tabular}




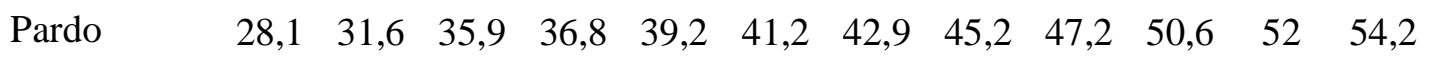

Renda

Renda

familiar per

capita / 25\%

$\begin{array}{llllllllllll}18,8 & 22 & 27,1 & 27,6 & 31 & 33 & 35,7 & 38 & 39,5 & 44,4 & 46,4 & 48,3\end{array}$

mais pobres

Renda

familiar per

capita / $25 \%$

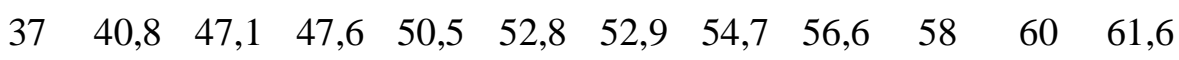

a $50 \%$

Renda

familiar per

capita / 50\%

$\begin{array}{llllllllllll}57,3 & 59,6 & 65,7 & 66,5 & 66,6 & 68,1 & 67,8 & 69,9 & 70,7 & 69,1 & 70,4 & 73,5\end{array}$

a $75 \%$

Renda

familiar per

capita / $25 \%$

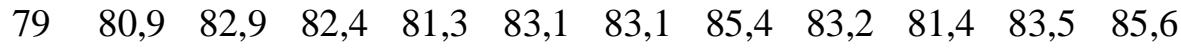

mais ricos

Fonte: Elaboração própria a partir dos dados do Observatório PNE

Como pôde ser observado, nas desiguladades educacionais, o acesso às etapas da educação básica ou obrigatória (pré-escola, Ensino Fundamental e Ensino Médio) está próximo aos 100\% apenas no Ensino Fundamental, apesar de ter havido uma ampliação ao longo do tempo dos outros niveis educacionais e da faixa etária - dos 4 aos 17 anos -, que fazem parte da obrigatoriedade escolar.

Além disso, a distribuição de matrículas se dá de forma bastante desigual segundo a região geográfica, a localização da escola, a raça e a renda familiar per capita dos alunos. Essa desigualdade é maior no Ensino Médio do que nas outras duas etapas da Educação Básica. De um modo geral, são as crianças e os jovens de renda familiar per capita baixa (25\% mais pobres), de cor preta, residentes em áreas rurais e da Região Norte as que têm menor acesso às escolas que oferecem educação básica. Essa situação revela a extrema desigualdade de oportunidades (de acesso) e de tratamento (segundo grupos sociais) (WALTENBERG, 2002; CRAHAY, 2002; DUBET, 2004a) do sistema educacional brasileiro.

É por causa da falta de garantia plena do direito subjetivo da população de 4 a 17 anos, neste caso em termos de acesso às diferentes etapas da educação básica, que grande parte das metas do PNE são traçadas na perspectiva de sua universalização. É consenso que o dever primeiro do Estado é garantir a 
oportunidade de acesso à educação e que essas oportunidades devem ser distribuídas igualitariamente entre os diferentes grupos sociais. Neste caso, é importante ressaltar que as metas estabelecidas pelo PNE não são inovadoras nem audaciosas, apenas visam contrinbuir para o exercício concreto de direitos educacionais constitucionalmente estabelecidos, e que já foram conquistados há tempos por outros países desenvolvidos e em desenvolvimento.

\subsubsection{A desigualdade da qualidade educacional}

\section{Aprendizado}

A qualidade da educação ofertada também é um componente da análise das desigualdades das oportunidades educacionais. Além de garantir o acesso, é preciso também garantir a aprendizagem dos alunos em patamares adequados. $\mathrm{Ou}$ seja, para que as oportunidades educacionais se efetivem plenamente, não basta apenas ter acesso à escola, é preciso também aprender.

Segundo Oliveira (2007), um dos efeitos provocados pela (quase) universalização do acesso ao Ensino Fundamental foi o debate acerca da democratização do conhecimento e da aprendizagem. No momento em que um contigente populacional anteriormente excluído passou a ingressar e permanecer no sistema educacional, emergiu com o força o desafio da democratização do conhecimento historicamente acumulado. "A superação da exclusão por falta de escola e pelas múltiplas reprovações tende a visibilizar a exclusão gerada pelo não aprendizado ou pelo aprendizado insuficiente, remetendo ao debate acerca da qualidade do ensino." (OLIVEIRA, 2007, p. 686). Portanto, o problema da exclusão educacional apenas mudou de lugar: antes ela se dava pela falta de acesso, agora ela se dá pela falta de conhecimento adequado.

Nesse sentido, o tema da qualidade do ensino e da garantia do aprendizado passaram a fazer parte da agenda política e se colocam, nos dias de hoje, como prioridades, sobretudo na etapa referente à alfabetização. Isso pode ser percebido pela implementação recente das políticas já citadas - ANA, PNAIC e meta 5 do PNE. 
A partir dos resultados referentes à aprendizagem adequada no $3^{\circ}$ ano do Ensino Fundamental, obtidos na ANA (2014), é possível analisar a desigualdade da aprendizagem de forma desagregada apenas por regiões geográficas.

A pontuação obtida na ANA é apresentada numa escala dividida em quatro níveis para Leitura e Matemática, e em cinco níveis para Escrita. Cada nível possui a descrição das habilidades e competências dos alunos. Segundo Soares (2009), a apresentação dos resultados em níveis de desempenho ao invés de média de desempenho é mais adequada, pois traz, como importante consequência pedagógica, a categorização dos estudantes em níveis de desempenho, possibilitando à escola promover atividades que possam atendê-los de maneira mais específica. Nesse sentido, a introdução de níveis possibilitou a incorporação da questão da equidade no indicador de resultados.

A divulgação dos resultados por níveis de desempenho, definidos por "pontos de corte criteriosamente escolhidos, pedagogicamente desafiantes e substantivamente relevantes" (SOARES, 2009, p, 40) permite o acompanhamento da qualidade e da equidade do sistema educacional brasileiro. $\mathrm{O}$ anexo 2 apresenta os níveis de desempenho em Leitura, Escrita e Matemática e a descrição das habilidades e competências referentes a cada nível.

Os dados da Tabela 7apresentam o percentual de alunos com aprendizado adequado no Brasil, por regiões geográficas e por nível de desempenho. Entre nós, 77,8\% dos alunos do $3^{\circ}$ ano Ensino Fundamental possuem aprendizado considerado adequado (níveis 2, 3 e 4) em Leitura, ao passo que 22,2\% possuem aprendizado insatisfatório. Ou seja, aproximadamente 1 em cada 5 alunos brasileiros não possui nível de aprendizado considerado adequado para o $3^{\circ}$ ano do Ensino Fundamental, o que significa que há lacunas na aprendizagem de Leitura que não lhe garante uma plena alfabetização. Além disso, o percentual de alunos com aprendizado adequado é muito desigual quando se observa esse indicador por região: no Nordeste, apenas $64,9 \%$ dos alunos conseguiram atingir um nível adequado de aprendizado, enquanto que no Sul, esse percentual é de $88,1 \%$. 
Tabela 7: Porcentagem de crianças do $3^{\circ}$ ano do Ensino Fundamental por nível de proficiência em Leitura (2014) - ANA

\begin{tabular}{lccccc}
\hline & Nível 1 & Nível 2 & Nível 3 & Nível 4 & Adequado \\
Brasil & 22,2 & 34 & 32,6 & 11,2 & 77,8 \\
Norte & 35,1 & 37,5 & 22,6 & 4,8 & 64,9 \\
Nordeste & 35,6 & 36,8 & 22,1 & 5,5 & 64,4 \\
Sudeste & 13,1 & 30,3 & 39,9 & 16,8 & 86,9 \\
Sul & 11,9 & 33,6 & 40,6 & 13,9 & 88,1 \\
Centro-oeste & 16,1 & 36,2 & 37,2 & 10,5 & 83,9 \\
\hline \multicolumn{5}{l}{ Fonte: Elaboração própria a partir dos dados do Observatório PNE }
\end{tabular}

Para o domínio da Escrita, o percentual de alunos com aprendizado adequado (níveis 4 e 5) é de 65,5\% mas novamente se observa a desigualdade na aquisição da Escrita pelos alunos segundo a região geográfica: enquanto que no Norte $42,9 \%$ dos estudantes possuem aprendizado adequado, no Sul, esse percentual é de $81,5 \%$, ou seja, quase o dobro.

Tabela 8: Porcentagem de crianças do $3^{\circ}$ ano do Ensino Fundamental por nível de proficiência em Escrita (2014) - ANA

\begin{tabular}{lcccccc}
\hline & Nível 1 & Nível 2 & Nível 3 & Nível 4 & Nível 5 & Adequado \\
Brasil & 11,6 & 15 & 7,8 & 55,7 & 9,9 & 65,5 \\
Norte & 19,4 & 27,4 & 10,4 & 38,8 & 4,1 & 42,9 \\
Nordeste & 19,9 & 22,5 & 11,4 & 42,5 & 3,7 & 46,3 \\
Sudeste & 6,1 & 8,8 & 5 & 64,6 & 15,4 & 80,1 \\
Sul & 5,1 & 8,1 & 5,3 & 67,5 & 14 & 81,5 \\
Centro-oeste & 7,8 & 11,1 & 8,5 & 65,1 & 7,5 & 72,6 \\
\hline \multicolumn{5}{l}{ Fonte: Elaboração própria a partir dos dados do Observatório PNE }
\end{tabular}

Em Matemática, o percentual de alunos com aprendizado adequado é significativamente inferior tanto ao de Leitura quanto ao de Escrita: apenas 42,9\% dos alunos brasileiros do $3^{\circ}$ ano do Ensino Fundamental possuem um nível de aprendizado adequado (níveis 3 e 4). Mais uma vez é possível observar a enorme desigualdade desse percentual entre as regiões geográficas: no Norte, apenas $25,1 \%$ dos estudantes possuem aprendizado adequado, enquanto que no Sudeste esse percentual é de $57,1 \%$. 


\section{Tabela 9: Porcentagem de crianças do $3^{\circ}$ ano do Ensino Fundamental por nível de desempenho em Matemática (2014) - ANA}

\begin{tabular}{lccccc}
\hline & Nível 1 & Nível 2 & Nível 3 & Nível 4 & Adequado \\
Brasil & 24,3 & 32,8 & 17,8 & 25,1 & 42,9 \\
Norte & 37,4 & 37,5 & 13,3 & 11,8 & 25,1 \\
Nordeste & 38,6 & 35,5 & 12,9 & 13 & 25,9 \\
Sudeste & 14,1 & 28,8 & 21 & 36,1 & 57,1 \\
Sul & 14,1 & 32 & 21,4 & 32,5 & 53,9 \\
Centro-oeste & 19,1 & 35,8 & 20,6 & 24,5 & 45,1 \\
\hline \multicolumn{5}{l}{ Fonte: Elaboração própria a partir dos dados do Observatório PNE }
\end{tabular}

\section{Fluxo escolar}

O segundo compenente do conceito de qualidade educacional refere-se à taxa de distorção idade-série. Até meados da década de 1980, um erro referente ao conceito de repetência distorcia as estatísticas oficiais superestimando as taxas de evasão e subestimando as de repetência. Naquele período, era considerado repetente o aluno que se matriculava na mesma série cursada no ano anterior após ter sido considerado reprovado, seja pelo baixo desempenho ou pela frequência insuficiente. No entanto, Correa (2013, p.20), esclarece que o conceito correto de repetente é mais simples e mais abrangente: “repetente' seria qualquer aluno que se matriculasse na mesma série que no ano anterior, independente do motivo que o levasse a fazer isso."

Em junho de 1994, no IX Encontro Nacional dos Dirigentes dos Órgãos do Sistema Estatístico da Educação, que contou com a participação de todos os representantes das Secretarias Estaduais de Educação, aprovou-se esse novo conceito de repetência e, já no ano seguinte, as alterações para a coleta dessa informação foram feitas no Censo Escolar.

A clareza dada ao problema da repetência, permitiu que os gestores das redes municipais e estaduais de educação adotassem algumas políticas visando a melhoria do fluxo escolar. Dentre as estratégias adotadas para a regularização do fluxo, estão as Classes de Aceleração, a organização escolar em ciclos e a promoção automática. Segundo Correa (2013, p.21). 
O reflexo dessas medidas foi a queda consistente nas taxas de repetência ao longo das décadas de 1980 e 1990, principalmente na primeira série que, como vimos, se constituía no maior gargalo do sistema. A repetência, que estivera em um patamar de $60 \%$ nos anos 1980 , caiu para cerca de $45 \%$ na década de 1990 e recuou mais um pouco nos anos 2000, se estabilizando num patamar ainda alto, próximo dos $30 \%$.

A despeito da importante melhoria das taxas de fluxo escolar alcançadas na década de 1990, elas ainda são tão altas que colocam o Brasil como um dos países do mundo com maiores taxas de repetência (PISA/OCDE, 2011) ${ }^{13}$.

Segundo Correa (2013, p.20), a melhoria do fluxo escolar teve efeitos positivos:

\begin{abstract}
Permitiu, por exemplo, desobstruir a entrada do Ensino Fundamental para que outras crianças e jovens com idade entre 6 e 14 anos pudessem ter acesso aos bancos escolares, possibilitando taxas de atendimento de 98,2\% conforme dados da Pnad 2011, além de reduzir o atraso escolar dos alunos em todo o Ensino Fundamental
\end{abstract}

Apesar disso, a dimensão do problema da repetência pode ser antecipado pela taxa de distorção idade-série. Em um fluxo escolar perfeito, isto é, sem repetência, as crianças deveriam entrar no Ensino Fundamental aos 6 anos de idade e conclui-lo aos 14 anos. Todavia, os dados da Tabela 10mostram que a taxa de distorção idade-série para os anos iniciais do Ensino Fundamental ainda é alta. Embora essas taxas tenham melhorado desde 2006, em 2014 eram de 14,1\%, o que ainda é muito alto. Mas trata-se de uma taxa que não é aleatoriamente alta. Em 2014, na região Norte, a taxa de distorção idade-série é de $23 \%$, praticamente o dobro da taxa que o Sudeste apresentava em 2006. Em outras palavras, embora a queda dessa taxa seja observada em todas as regiões geográficas, sua variação ainda é muito grande.

\footnotetext{
${ }^{13}$ Em um item dos questionários contextuais do PISA de 2009 perguntou-se aos estudantes participantes, se eles já haviam repetido alguma vez durante sua trajetória escolar. Mais de $25 \%$ dos estudantes de Brasil, Argentina, Colômbia, Panamá, Peru, Trinidad e Tobago, Tunisia, Uruguai e Macau afirmam terem repetido ao menos uma série. No Brasil cerca de $13 \%$ dos estudantes relataram ter repetido ao menos uma vez. Destes, $7 \%$ repetiram ainda na escola primária.
} 

Tabela 10: Taxa de distorção idade-série - Anos Iniciais do Ensino
Fundamental - Todas as redes

\begin{tabular}{lccccccccc}
\hline & 2006 & 2007 & 2008 & 2009 & 2010 & 2011 & 2012 & 2013 & 2014 \\
Brasil & 23 & 22,6 & 17,6 & 18,6 & 18,5 & 17,8 & 16,6 & 15,4 & 14,1 \\
Norte & 37,1 & 36,7 & 26,1 & 29,8 & 30,7 & 29,5 & 27,4 & 25,3 & 23 \\
Nordeste & 34 & 33,9 & 24,2 & 26,6 & 26,6 & 25,3 & 23,5 & 21,8 & 19,9 \\
Sudeste & 12,8 & 12,6 & 11,6 & 11 & 10,6 & 10,3 & 9,9 & 9,2 & 8,5 \\
Sul & 12 & 12 & 11,6 & 11,6 & 12 & 12,2 & 11,3 & 10,7 & 9,9 \\
Centro-oeste & 18,9 & 18,9 & 16,2 & 15,8 & 15 & 14,4 & 13,5 & 12,5 & 11,2 \\
\hline Fonte: Elaboraça própria a partir dos dados do Observatório PNE
\end{tabular}

Fonte: Elaboração própria a partir dos dados do Observatório PNE

As Tabelas 11e 12apresentam a taxa de distorção idade-série dos anos iniciais do Ensino Fundamental por rede de ensino. Mais uma vez, a variação desse indicador se revela grande entre as regiões geográficas e, também, entre as redes de ensino. Em 2014, a rede pública brasileira possuia 16\% de alunos fora da série adequada nesta etapa, enquanto que na rede particular esse percentual era significativamente inferior, de 4,5\%. A variação desse indicador por região também é alta: enquanto no Norte $24,7 \%$ dos alunos da rede pública estão fora da série adequada, na região Sudeste este percentual é de 9,6\%. Na rede particular, esse indicador é bem inferior, mas também varia entre as regiões, como expressa, por exemplo, na taxa de distorção idade-série de 6,5\% dos estudantes do Nordeste em comparação com $2,1 \%$ no Sul.

\section{Tabela 11: Taxa de distorção idade-série - Anos Iniciais do Ensino Fundamental - Rede Pública}

\begin{tabular}{lccccccccc}
\hline & 2006 & 2007 & 2008 & 2009 & 2010 & 2011 & 2012 & 2013 & 2014 \\
Brasil & 25,1 & 24,6 & 19,4 & 20,6 & 20,7 & 20,1 & 18,9 & 17,6 & 16 \\
Norte & 38,6 & 38,1 & 27,3 & 31,4 & 32,4 & 31,2 & 29,2 & 27 & 24,7 \\
Nordeste & 36,9 & 36,6 & 26,5 & 29,5 & 29,9 & 28,7 & 26,9 & 25,1 & 23 \\
Sudeste & 14,1 & 13,9 & 12,9 & 12,3 & 12 & 11,7 & 11,2 & 10,5 & 9,6 \\
Sul & 12,9 & 12,7 & 12,6 & 12,6 & 13,1 & 13,4 & 12,5 & 11,8 & 11,1 \\
Centro-oeste & 21,1 & 20,7 & 18,3 & 17,9 & 17,1 & 16,5 & 15,6 & 14,5 & 13 \\
\hline
\end{tabular}

Fonte: Elaboração própria a partir dos dados do Observatório PNE 


\section{Tabela 12: Taxa de distorção idade-série - Anos Iniciais do Ensino} Fundamental - Rede Particular

\begin{tabular}{lccccccccc}
\hline & 2006 & 2007 & 2008 & 2009 & 2010 & 2011 & 2012 & 2013 & 2014 \\
Brasil & 4,9 & 5,2 & 4,1 & 4,3 & 4,3 & 4,3 & 4,5 & 4,5 & 4,5 \\
Norte & 6 & 6,4 & 5,2 & 5,2 & 5 & 5 & 5,1 & 4,8 & 4,7 \\
Nordeste & 7,3 & 7,6 & 5,7 & 6,2 & 6,1 & 6 & 6,5 & 6,5 & 6,5 \\
Sudeste & 3,8 & 3,7 & 3,4 & 3,5 & 3,4 & 3,6 & 3,7 & 3,8 & 3,8 \\
Sul & 1,9 & 4,1 & 2,1 & 2,1 & 2,4 & 2,3 & 2,3 & 2,2 & 2,1 \\
Centro-oeste & 3,9 & 5,1 & 3,2 & 3,2 & 3,1 & 3 & 2,9 & 2,8 & 2,7 \\
\hline Fonte: Elaboração própria a partir dos dados do Observatório PNE
\end{tabular}

\subsection{A região Sudeste e a desigualdade de oportunidades educacionais}

Como já observado nos dados apresentados na seção anterior deste capítulo, o Sudeste é a região que possui os melhores indicadores de oferta escolar, aprendizado adequado e taxa de distorção idade-série quando comparado com as demais regiões do país. Nesta seção, esses mesmos indicadores serão analisados para os quatro estados desta região.

\subsubsection{A desigualdade de acesso da região Sudeste}

A oferta de vagas nas escolas/creches brasileiras para as crianças de 0 a 3 anos ainda é um desafio até mesmo para as regiões Sul e Sudeste, que possuem as melhores taxas de atendimento: $35,2 \%$ e $33,1 \%$, respectivamente. A série histórica dos dados mostra que o percentual de crianças de 0 a 3 anos na creche vem aumentando, apesar de uma pequena queda entre os anos de 2004 e 2005. São Paulo, o estado com maior PIB do país, possuía, em 2013, uma taxa de matricula de 36,6\% para a faixa etária, enquanto em Minas Gerais, essa taxa era de 26,3\%. Isso mostra que mesmo os estados mais ricos e desenvolvidos economicamente possuem taxas de atendimento insatisfatórias. No Espírito Santo, o percentual de alunos é de $30,4 \%$. Ou seja, perto de $1 / 3$ da população da faixa etária. 
Tabela 13: Porcentagem de crianças de 0 a 3 anos na escola - Todas as redes - Região Sudeste

\begin{tabular}{|c|c|c|c|c|c|c|c|c|c|c|c|c|}
\hline & 2001 & 2002 & 2003 & 2004 & 2005 & 2006 & 2007 & 2008 & 2009 & 2011 & 2012 & 2013 \\
\hline Sudeste & 15 & 16,5 & 16,7 & 20,2 & 19,5 & 23,6 & 26,7 & 27,5 & 27,7 & 30,8 & 29,8 & 33,1 \\
\hline $\begin{array}{l}\text { Minas } \\
\text { Gerais }\end{array}$ & 11,7 & 11,9 & 12,2 & 15,9 & 14,7 & 17,4 & 19,8 & 21,2 & 21,1 & 23,3 & 22,8 & 26,3 \\
\hline $\begin{array}{l}\text { Espírito } \\
\text { Santo }\end{array}$ & 15,8 & 17,2 & 19,2 & 21,3 & 23,2 & 20,2 & 28,3 & 31,8 & 26,5 & 31 & 36,6 & 30,4 \\
\hline $\begin{array}{l}\text { Rio de } \\
\text { Janeiro }\end{array}$ & 16,2 & 20,6 & 18,5 & 22,5 & 20,6 & 26 & 27,4 & 26,5 & 26,8 & 30,9 & 29,2 & 33 \\
\hline $\begin{array}{l}\text { São } \\
\text { Paulo }\end{array}$ & 16,2 & 17,4 & 18,2 & 21,4 & 21,2 & 26,3 & 29,8 & 30,6 & 31,3 & 34,5 & 32,7 & 36,6 \\
\hline
\end{tabular}

A Tabela 14apresenta o percentual de alunos na creche, em 2013, por raça/cor. Ao contrário do que acontece nas demais etapas da escolarização, o percentual de alunos de cor preta é maior em todos os estados, com exceção do Rio de Janeiro, em que é maior o percentual de brancos. Enquanto que nos estados de Minas Gerais, Espírito Santo e Rio de Janeiro o percentual de alunos pretos na escola/creche gira em torno de 33\%, em São Paulo esse percentual é muito maior, de 47,5\%. No Espírito Santo, a variação desse percentual de atendimento por raça/cor dos alunos é pequena e mais homogênea e, portanto, menos desigual.

Tabela 14: Porcentagem de crianças de 0 a 3 anos na escola por raça/cor (2013) - Todas as redes - Região Sudeste

\begin{tabular}{|c|c|c|c|}
\hline & Brancos & Pretos & Pardos \\
\hline Sudeste & 33,9 & 38,4 & 30,9 \\
\hline Minas Gerais & 28,9 & 33 & 22,8 \\
\hline Espírito Santo & 30,1 & 33,3 & 30,3 \\
\hline Rio de Janeiro & 35,1 & 32,8 & 30,4 \\
\hline São Paulo & 35,5 & 47,5 & 37,4 \\
\hline
\end{tabular}

O Sudeste possui a segunda maior taxa de crianças de 4 e 5 anos que frequentam a escola, ficando atrás só do Nordeste, que possui taxa de 92,6\%. Como já mencionado, a Emenda Constitucional $n^{0}$ 59/2009 ampliou a obrigatoriedade da educação básica, o que fez aumentar a oferta de pré-escola. 
A série histórica do percentual de alunos de 4 a 5 anos na escola, na região Sudeste, apresentada na Tabela 15, revela que essa oferta vem aumentando, sem ter conseguido atingir a plena universalização, pelo menos até 2013. Assim, todos os sistemas educacionais da região Sudeste precisam ampliar a oferta desta etapa escolar para cumprir a meta 1 do PNE, que prevê a universalização do acesso até o ano de 2016. De acordo com os dados, a variação do percntual entre os quatro estados não é muito grande, sendo Espírito Santo e São Paulo os estados com maior percentual de alunos na pré-escola, de $91,2 \%$ e $91,4 \%$, respectivamente.

\section{Tabela 15: Porcentagem de crianças de 4 a 5 anos na pré-escola - Todas as redes - Região Sudeste}

\begin{tabular}{lcccccccccccc}
\hline & 2001 & 2002 & 2003 & 2004 & 2005 & 2006 & 2007 & 2008 & 2009 & 2011 & 2012 & 2013 \\
\hline Sudeste & 69,8 & 70,3 & 73,2 & 77,5 & 76,4 & 82 & 83,3 & 84,5 & 87 & 89,6 & 88,4 & 90,5 \\
Minas & 62,9 & 63,8 & 66,9 & 73,6 & 70,3 & 74,3 & 77,5 & 81,2 & 82,5 & 85,8 & 88,1 & 88,7 \\
Gerais & & & & & & & & & & & & \\
$\begin{array}{l}\text { Espírito } \\
\text { Santo }\end{array}$ & 63,7 & 66,7 & 67,3 & 73 & 71,5 & 83,6 & 79,4 & 82,7 & 83,2 & 90,3 & 93,3 & 91,2 \\
$\begin{array}{l}\text { Rio de } \\
\text { Janeiro }\end{array}$ & 77,9 & 76 & 81,3 & 83,8 & 80,6 & 85,7 & 83,5 & 86,7 & 86,2 & 88,6 & 88,1 & 89,8 \\
São Paulo & 70,8 & 72,1 & 73,8 & 77,7 & 78,4 & 84,6 & 86,7 & 85,6 & 89,8 & 91,8 & 88,2 & 91,4 \\
\hline Fonte: Elaboração própria a partir dos dados do Observatório PNE & & & & & & & & & & & &
\end{tabular}

A Tabela 16mostra o percentual de alunos de 4 a 5 anos por raça/cor na escola no ano de 2013. Nos estados de Minas Gerais e Espírito Santo, o percentual de estudantes pretos é maior que o de estudantes brancos. No Espírito Santo, atinge $100 \%$ entre os alunos pretos e $88,7 \%$, para os brancos, o que indica, desta vez, certa desigualdade de acesso segundo a raça/cor em favor dos pretos. Esse dado surpreende por dois motivos: 1) tem-se, uma taxa de $100 \%$ de atendimento para um grupo social que recorrentemente apresenta dados educacionais de acesso escolar inferiores aos demais grupos (brancos e pardos); 2) os dados educacionais brasileiros de praticamente todas as etapas e modalidades de ensino revelam que a desigualdade de acesso e de qualidade do ensino de forma sistemática desfavorece os alunos pretos.

Este resultado se coloca a favor da equidade de raça/cor no acesso à escola de crianças de 4 e 5 anos de acordo com a cor, no Estado de Espírito Santo e se 
torna particularmente importante se levarmos que uma série de pesquisas internacionais encontram impacto positivo no desempenho cognitivo ao longo da escolaridade posterior de crianças que foram contempladas por programas de Educação Infantil, além de reportarem que esse impacto é mais acentuado para os grupos de crianças de nível socioeconômico mais baixo (CAMPOS, 1997). Além disso, estudo de Campos (2011) que considera a qualidade das experiências educativas vividas pelas crianças na etapa anterior ao Ensino Fundamental, em três capitais brasileiras, identifica diferenças positivas no desempenho escolar de crianças no início do Ensino Fundamental associadas à frequência de uma préescola de qualidade. Utilizando um modelo hierárquico multinível, que permite levar em conta, simultaneamente, o efeito de diversas variáveis explicativas (características dos alunos e de suas famílias; das escolas de EI e das escolas de EF) sobre os resultados da variável resposta (as notas dos alunos do segundo ano na Provinha Brasil), o estudo revela que a frequência à pré-escola de boa qualidade influi positivamente no desempenho dos alunos nesta avaliação.

\section{Tabela 16: Porcentagem de crianças de 4 a 5 anos na escola por cor/raça (2013) - Todas as redes - Região Sudeste}

\begin{tabular}{lccc}
\hline & Brancos & Pretos & Pardos \\
\hline Sudeste & 92 & 89,3 & 88,4 \\
Minas Gerais & 91,8 & 92,8 & 85,5 \\
Espírito Santo & 88,7 & 100 & 92 \\
Rio de Janeiro & 93,1 & 82,7 & 88 \\
São Paulo & 91,9 & 91,5 & 90,2 \\
\hline \multicolumn{4}{l}{ Fonte: Elaboração própria a partir dos dados do } \\
Observatório PNE
\end{tabular}

Como já visto na seção anterior, embora a taxa de matrícula líquida das crianças de 6 a 14 anos no Ensino Fundamental não tenha alcançado 100\%, podese dizer que o acesso a esta etapa escolar está praticamente universalizado. Os dados da Tabela 17mostram que todos os estados da região Sudeste possuem altas taxas de matrícula nessa etapa e que a variação dessa taxa é muito pequena. 
Tabela 17: Porcentagem de crianças de 6 a 14 anos matriculadas no Ensino Fundamental - Taxa líquida de matrícula - Todas as redes - Região Sudeste

\begin{tabular}{lcccccc}
\hline & 2007 & 2008 & 2009 & 2011 & 2012 & 2013 \\
\hline Sudeste & 95,7 & 96,6 & 97,3 & 97,6 & 97,7 & 98 \\
Minas Gerais & 95,1 & 96,6 & 97,2 & 97,4 & 97,9 & 98,1 \\
Espírito Santo & 94,4 & 96,9 & 96,9 & 97,5 & 96,9 & 97,3 \\
Rio de Janeiro & 96,8 & 97,4 & 97,7 & 97,5 & 97,4 & 97,8 \\
São Paulo & 95,6 & 96,4 & 97,2 & 97,8 & 97,7 & 98,1 \\
\hline
\end{tabular}

Fonte: Elaboração própria a partir dos dados do Observatório PNE

Uma vez que a universalização do Ensino Fundamental, alavancada pelo FUNDEF e pela LDB de 1996, está quase garantida, é esperado que a variação da taxa de matrícula líquida por raça/cor seja muito pequena. É o que de fato os dados da Tabela 18 revelam, apesar de, em todos os estados, com exceção de São Paulo, essa taxa ser ligeiramente maior para o grupo de estudantes de cor parda. Em São Paulo, é ligieramente maior para os alunos de cor branca.

\section{Tabela 18: Porcentagem de crianças de 6 a 14 anos matriculadas no Ensino Fundamental por cor/raça - Taxa líquida de matrícula (2013) - Todas as redes - Região Sudeste}

\begin{tabular}{lccc}
\hline & Brancos & Pretos & Pardos \\
\hline Sudeste & 98,1 & 97,8 & 97,9 \\
Minas Gerais & 97,8 & 97,9 & 98,2 \\
Espírito Santo & 96,4 & 97,4 & 97,8 \\
Rio de Janeiro & 97,6 & 97,9 & 98,1 \\
São Paulo & 98,4 & 97,7 & 97,7 \\
\hline \multicolumn{4}{l}{ Fonte: Elaboração própria a partir dos dados do }
\end{tabular}

Observatório PNE

Por fim, como apresentado na seção anterior, a região Sudeste apresenta a maior taxa de líquida de matrícula dos alunos de 15 a 17 anos no Ensino Médio, com 67,8\%. A série histórica apresentada na Tabela 19 mostra a evolução da taxa de matrícula líquida no período 2001-2013. De acordo com os dados, Minas Gerais ampliou a sua taxa de matrícula líquida em torno de 23 pontos percentuais enquanto no Rio de Janeiro o aumento foi de apenas 12 pontos percentuais. Além disso, observa-se que, em 2013, a taxa de matrícula líquida era de 59,3\% e 59\% para Espírito Santo e Rio de Janeiro, respectivamente, e que esses valores são 
inferiores à taxa de matrícula líquida de São Paulo no ano de 2001, que já era de $59,9 \%$.

Ao contrário do que se observou nos indicadores das outras etapas da escolarização obrigatória, no Ensino Médio, há uma variação grande da oferta escolar entre os estados do Sudeste, onde as taxas de atendimento são significativamente menores que nas demais etapas. Em outras palavras: os sistemas educacionais dos estados da região Sudeste estão ampliando significativamente o acesso à pré-escola, e já universalizaram o Ensino Fundamental, mas não estão conseguindo ampliar da mesma forma o acesso ao Ensino Médio.

A hipótese mais plausível que pode explicar essa situação é a elevada taxa de distorção idade-série do Ensino Fundamental, o que remete às elevadas taxas de repetência que é, ainda, muito alta.Nessa perspectiva, é provável que a ampliação do acesso ao Ensino Médio dos estudantes de 15 a 17 anos esteja sendo dificultada pela elevada taxa de distorção idade-série que ainda persiste no Ensino Fundamental.

\section{Tabela 19: Porcentagem de jovens de 15 a 17 anos matriculados no Ensino Médio - Taxa líquida de matrícula - Todas as redes - Região Sudeste}

\begin{tabular}{lcccccccccccc}
\hline & 2001 & 2002 & 2003 & 2004 & 2005 & 2006 & 2007 & 2008 & 2009 & 2011 & 2012 & 2013 \\
\hline Sudeste & 52,2 & 55,7 & 60,3 & 61,8 & 61,9 & 62,2 & 63,5 & 65,6 & 64,5 & 64,2 & 67 & 67,8 \\
$\begin{array}{l}\text { Minas } \\
\text { Gerais }\end{array}$ & 42,5 & 47,5 & 52,1 & 54,2 & 55,5 & 55,1 & 55,3 & 60,4 & 57,7 & 58,9 & 64 & 65,9 \\
$\begin{array}{l}\text { Espírito } \\
\text { Santo }\end{array}$ & 44,4 & 49,5 & 50 & 53,9 & 49 & 51,5 & 45,9 & 54,4 & 55,1 & 59 & 58,6 & 59,3 \\
$\begin{array}{l}\text { Rio de } \\
\text { Janeiro }\end{array}$ & 46,8 & 47,2 & 52,1 & 52,3 & 52,2 & 54,2 & 59,4 & 57,5 & 56,6 & 54,9 & 57,3 & 59 \\
São Paulo & 59,9 & 63,8 & 68,3 & 69,8 & 70,2 & 70,4 & 71,3 & 72,7 & 72,2 & 71,9 & 74 & 73,8 \\
\hline
\end{tabular}

Fonte: Elaboração própria a partir dos dados do Observatório PNE

A Tabela 20 apresenta os dados da taxa de matrícula líquida do jovens de 15 a 17 anos no Ensino Médio por raça/cor. Ao contrário do que foi observado nas etapas anteriores da escolarização obrigatória, a variação desse indicador é significativa entre os estados e também entre grupos de raça/cor. Em todos os estados, a taxa de matrícula líquida é maior para o grupo de estudantes brancos. 
Em São Paulo e Rio de Janeiro, a taxa é ligeiramente maior para pretos que para pardos.

Na faixa etária dos 15 aos 17 anos, os dados do Espírito Santo mostram que no grupo de estudantes de cor branca a taxa de matrícula líquida é de 73,8\%, ao passo que para os estudantes de cor preta, essa taxa é de $36,8 \%$, revelando uma grande desigualdade entre esses dois grupos de cor. O mais inusitado é que nas etapas anteriores, o percentual de acesso dos alunos de cor preta sempre foi superior ao dos de cor branca, principalmente no acesso de crianças de 4 a 5 anos à pré-escola, quando esse percentual entre alunos de cor preta é de $100 \%$.

Tabela 20: Porcentagem de jovens de 15 a 17 anos matriculados no Ensino Médio por cor/raça - Taxa líquida de matrícula (2013) - Todas as redes Região Sudeste

\begin{tabular}{lccc}
\hline & Brancos & Pretos & Pardos \\
\hline Sudeste & 74,8 & 59,1 & 62,2 \\
Minas Gerais & 71,6 & 53,8 & 63,7 \\
Espírito Santo & 73,8 & 36,8 & 53,3 \\
Rio de Janeiro & 67,7 & 54,5 & 52,3 \\
São Paulo & 78,6 & 69,3 & 67,4 \\
\hline \multicolumn{4}{l}{ Fonte: Elaboração própria a partir dos dados do } \\
Observatório PNE
\end{tabular}

\subsubsection{A desigualdade da qualidade educacional da região Sudeste}

\section{Aprendizado}

Como já abordado neste capítulo, a região Sudeste possui um dos melhores indicadores de aprendizado no $3^{\circ}$ ano do Ensino Fundamental segundo os dados da ANA (2014), Em Leitura, 86,9\% dos estudantes possuem um nível de aprendizado considerado adequado. Apesar disso, há variações significativas entre os estados do Sudeste. Por exemplo, Rio de Janeiro têm o menor percentual de alunos com nível de aprendizado adequado em Leitura: 21,6\% de estudantes no nível 1, 37,7\% no nível 2 e apenas 8,4\% no nível 4 da escala de desempenho da ANA. Ou seja, a maioria dos alunos situa-se nos níveis mais baixos da escala, 
embora o nível 2 seja considerado um nível de aprendizado adequado. Do outro lado, Mina Gerais tem o maior percentual de alunos com aprendizado adequado, com a maioria deles nos níveis 3 e 4 da escala de desempenho, que são considerados adequados. A diferença percentual de estudantes com aprendizado adequado entre esses dois estados é significativa, bem como o é a distribuição dos alunos entre os níveis de desempenho da escala da ANA, com 9,3\% e 21,6\% de alunos com aprendizado insatisfatório (nível 1), respectivamente, em Minas Gerais e Rio de Janeiro.

Tabela 21: Porcentagem de crianças do $3^{\circ}$ ano do Ensino Fundamental por nível de proficiência em Leitura (2014) - Todas as redes - Região Sudeste ANA

\begin{tabular}{lccccc}
\hline & Nível 1 & Nível 2 & Nível 3 & Nível 4 & Adequado \\
\hline Sudeste & 13,1 & 30,3 & 39,9 & 16,8 & 86,9 \\
Minas Gerais & 9,3 & 26,9 & 42,1 & 21,7 & 90,8 \\
Espírito Santo & 16,3 & 33,4 & 37,1 & 13,2 & 83,7 \\
Rio de Janeiro & 21,6 & 37,7 & 32,3 & 8,4 & 78,4 \\
São Paulo & 11,5 & 28,9 & 41,8 & 17,8 & 88,5 \\
\hline Fonte: Elaboração própria a partir dos dados do Observatório PNE
\end{tabular}

No domínio da Escrita, o percentual de alunos com aprendizado adequado é menor que para Leituraem todos os estados, e as diferenças são significativas. São Paulo é o estado que possui maior percentual de alunos com aprendizado adequado eo Rio de Janeiro possui a menor taxa. Enquanto Minas Gerais e São Paulo possuem 4,4\% e 4,9\%, respectivamente, de alunos no nível 1 da escala, Rio de Janeiro possui mais que o dobro, 10,7\%. Por outro lado, São Paulo tem 20,2\% de estudantes no nível 5 da escala, enquanto que Espírito Santo tem apenas 5,9\%. Observa-se, portanto, um diferença signifcativa de alunos nos cinco níveis de desempenho da escala ANA, sendo Minas Gerais e São Paulo os estados com os melhores percentuais nos níveis mais altos de proficiência em Escrita (Tabela 22).

Tabela 22: Porcentagem de crianças do $3^{\circ}$ ano do Ensino Fundamental por nível de proficiência em Escrita (2014) - Todas as redes - Região Sudeste ANA

\begin{tabular}{lcccccc}
\hline & Nível 1 & Nível 2 & Nível 3 & Nível 4 & Nível 5 & Adequado \\
\hline Sudeste & 6,1 & 8,8 & 5 & 64,6 & 15,4 & 80,1
\end{tabular}




\begin{tabular}{lcccccc} 
Minas Gerais & 4,4 & 7,3 & 7,9 & 69,5 & 10,8 & 80,3 \\
Espírito Santo & 8,7 & 11,4 & 10,1 & 63,9 & 5,9 & 69,9 \\
Rio de Janeiro & 10,7 & 15,2 & 6,5 & 57,4 & 10,1 & 67,5 \\
São Paulo & 4,9 & 7,1 & 2,7 & 65 & 20,2 & 85,3 \\
\hline \multicolumn{5}{l}{ Fonte: Elaboração própria a partir dos dados do Observatório PNE }
\end{tabular}

Em Matemática, o percentual de estudantes com aprendizado adequado no $3^{\circ}$ ano do Ensino Fundamental é significativamente inferior ao de Leitura e Escritaem todos os estados. O fato de que as competências e habilidades desenvolvidas naMatemática sejam mais escolares que as de Leitura pode estar relacionado a esse resultado, que reforça a ideia de que o desempenho dos alunos nas avaliações em larga escala nos testes de Matemática depende mais da escola do que da origem social e das carcaterísticas próprias do aluno. Apesar disso, dentre as cinco regiões geográficas do Brasil, o Sudeste é a que possui o maior percentual de alunos com aprendizado adequado. Se as diferenças dos dados na Leitura e na Escrita eram significativas, na Matemática elas são ainda mais expressivas. Enquanto Minas Gerais apresenta 62,7\% de alunos com aprendizado adequado, no Rio de Janeiro, esse percentual é de 38,7. Além disso, 40,6\% e 40,4\% dos alunos de Minas Gerais e São Paulo, respectivamente, situam-se no nível 4 da escala da ANA, enquanto no Espírito Santo e Rio de Janeiro esses percentuais são de $29,2 \%$ e de $20 \%$, respectivamente.

\section{Tabela 23: Porcentagem de crianças do $3^{\circ}$ ano do Ensino Fundamental por nível de proficiência em Matemática (2014) - Todas as redes - Região Sudeste - ANA}

\begin{tabular}{lccccc}
\hline & Nível 1 & Nível 2 & Nível 3 & Nível 4 & Adequado \\
\hline Sudeste & 14,1 & 28,8 & 21 & 36,1 & 57,1 \\
Minas Gerais & 11,1 & 26,3 & 22,1 & 40,6 & 62,7 \\
Espírito Santo & 17,8 & 32,8 & 20,2 & 29,2 & 49,3 \\
Rio de Janeiro & 23,9 & 37,3 & 18,8 & 20 & 38,7 \\
São Paulo & 11,8 & 26,6 & 21,3 & 40,4 & 61,7 \\
\hline
\end{tabular}

Fonte: Elaboração própria a partir dos dados do Observatório PNE

Como vimos, o Sudeste é uma das regiões que possui melhores indicadores educacionais, tanto no acesso à escola quanto na aprendizagem. $\mathrm{O}$ dados referentes ao aprendizado adequado em Leitura evidenciam que a região e seus quatro estados já atenderam a meta 3 do Movimento Todos pela Educação 
que estipula que, até o ano de 2022, $70 \%$ ou mais dos estudantes brasileiros devem ter o aprendizado adequado para seu ano escolar. No que concerne ao domínio da Escrita, Rio de Janeiro e Espírito Santo ainda não conseguiram alcançar o perentual estipulado pelo TPE, embora estejam bem perto de atingi-la. Em Matemática, a situação é um pouco pior porque, mesmo sendo a região com o maior percentual de alunos com aprendizado adequado, o Sudeste e seus estados ainda não atingiram a meta do TPE.

\section{Fluxo escolar}

A análise comparativa da seção anterior mostrou que, dentre as cincos regiões, o Sudeste possui a menor taxa de distorção idade-série na rede pública e na rede particular, e que as menores taxas de distorção idade-série estão nas regiões Sul $(2,1 \%)$ e Centro-Oeste $(2,7 \%)$.

No período analisado (2006-2014), a taxa de distorção idade-série do Sudeste cai progressivamente, atingindo, em 2014, o percentual de 8,5\%. No entanto, a melhora dessa taxa varia de um estado para outro. Minas Gerais consegue diminuir esse indicador ano a ano, enquanto que no Rio de Janeiro essa taxa é alta e fica estagnada até 2013, quando tem uma pequena queda. A taxa de distorção idade-série de São Paulo também é estável no período analisado, com patamares muito inferiores aos do Rio de Janeiro.

Em 2014, Minas Gerais e São Paulo possuíam as menores taxas, de 6,2\% e $4,5 \%$, respectivamente, enquanto o Rio de Janeiro apresentava uma taxa de distorção idade-série de 19,9\%, o que signifca dizer que 1 em cada 5 alunos estava fora da série adequada para a sua idade, evidenciando que o sistema de ensino do Rio de Janeiro tem problemas sérios de fluxo, resultado relacionado às persistentes retenções dos estudantes nos anos iniciais do Ensino Fundamental. 


\section{Tabela 24: Taxa de distorção idade-série - Anos Iniciais do Ensino Fundamental - Todas as redes - Região Sudeste}

\begin{tabular}{lccccccccc}
\hline & 2006 & 2007 & 2008 & 2009 & 2010 & 2011 & 2012 & 2013 & 2014 \\
Sudeste & 12,8 & 12,6 & 11,6 & 11 & 10,6 & 10,3 & 9,9 & 9,2 & 8,5 \\
Minas Gerais & 16 & 15,7 & 13,8 & 13,1 & 12 & 11 & 9,5 & 8 & 6,2 \\
Espírito Santo & 17,3 & 17,2 & 16,4 & 16,6 & 15,7 & 15 & 14,7 & 14,3 & 13,7 \\
Rio de Janeiro & 23,1 & 24,4 & 22,5 & 22,3 & 22 & 22,1 & 22 & 20,4 & 19,9 \\
São Paulo & 5,9 & 5,5 & 5,2 & 4,8 & 4,7 & 4,5 & 4,5 & 4,6 & 4,5 \\
\hline Fonte: Elaboracão própria a partir dos dados do Observatório PNE
\end{tabular}

Fonte: Elaboração própria a partir dos dados do Observatório PNE

Observando as taxas de distorção idade-série para as redes pública e privada, nas tabelas 25 e 26 , percebemos que essa taxa é maior para a rede pública de todos os estados. Além disso, é sempre significativamente inferior para São Paulo, em ambas as redes e, por isso, as diferenças ao longo do tempo são pequenas. A rede pública de Minas Gerais conseguiu reduzir expressivamente sua taxa de distorção idade-série no período analisado, mas não alcançou, em 2014, a taxa que São Paulo tinha em 2006. A rede pública do Rio de Janeiro manteve alta a taxa de distorção idade-série, que foi, em 2014, de 25,8\%, indicando que aproximadamente um a cada quatro alunos está fora da série certa para sua idade.

$\mathrm{Na}$ rede particular, Rio de Janeiro também apresenta uma taxa de distorção idade-série mais alta que as redes particulares dos demais estados. Ela só é bem menor $(7,7 \%)$, quando comparada com as taxas da rede pública, $(25,8 \%)$

Os dados apontam, portanto, que, nos anos iniciais do Ensino Fundamental, é baixo o percentual de alunos fora da série adequada para a sua idade em ambas as redes de ensino de São Paulo. Já Minas Gerais, apresentava, em 2006, uma alta taxa de distorção idade-série principalmente na rede pública, que cai ao longo do período, estudado.

Espírito Santo possui taxas de distorção idade-série elevadas na rede pública, embora estas sejam menores que as do Rio de Janeiro. Apesar de uma pequena redução no período, em 2014, é muito alto o percentual de alunos fora da série correta para a sua idade $(15,3 \%)$. 
Tabela 25: Taxa de distorção idade-série - Anos Iniciais do Ensino Fundamental - Rede Pública - Região Sudeste

\begin{tabular}{lccccccccc}
\hline & 2006 & 2007 & 2008 & 2009 & 2010 & 2011 & 2012 & 2013 & 2014 \\
Sudeste & 14,1 & 13,9 & 12,9 & 12,3 & 12 & 11,7 & 11,2 & 10,5 & 9,6 \\
Minas Gerais & 17,1 & 16,5 & 14,8 & 14,1 & 12,9 & 12 & 10,4 & 8,7 & 6,7 \\
Espírito Santo & 18,8 & 18,9 & 18,2 & 18,4 & 17,4 & 16,7 & 16,3 & 16 & 15,3 \\
Rio de Janeiro & 26,9 & 28,1 & 26,9 & 27 & 27 & 27,8 & 27,8 & 26,1 & 25,8 \\
São Paulo & 6,5 & 6,1 & 5,9 & 5,4 & 5,2 & 5,1 & 5,1 & 5,2 & 5,2 \\
\hline Fonte: Elaboração própria a partir dos dados do Observatório PNE
\end{tabular}

Fonte: Elaboração própria a partir dos dados do Observatório PNE

Tabela 26: Taxa de distorção idade-série - Anos Iniciais do Ensino Fundamental - Rede Particular - Região Sudeste

\begin{tabular}{lccccccccc}
\hline & 2006 & 2007 & 2008 & 2009 & 2010 & 2011 & 2012 & 2013 & 2014 \\
Sudeste & 3,8 & 3,7 & 3,4 & 3,5 & 3,4 & 3,6 & 3,7 & 3,8 & 3,8 \\
Minas Gerais & 3,8 & 4,9 & 2,8 & 2,6 & 2,6 & 2,7 & 2,5 & 2,6 & 2,3 \\
Espírito Santo & 4,2 & 2,7 & 2,2 & 2,4 & 2,2 & 2,2 & 2,2 & 2,2 & 2,1 \\
Rio de Janeiro & 6,6 & 6,8 & 6,6 & 6,9 & 6,8 & 6,9 & 7,3 & 7,5 & 7,7 \\
São Paulo & 2 & 1,8 & 1,8 & 1,7 & 1,7 & 1,8 & 1,9 & 1,8 & 1,9 \\
\hline Fonte: Elaboração própria a partir dos dados do Observatório PNE & & & & &
\end{tabular}

Este capítulo teve como principal objetivo mapear a desigualdade de oportunidades educacionais (acesso e qualidade) no Brasil. Para isso, optou-se por analisar dados de acesso às diversas etapas da Educação Básica, incluindo a creche, ou seja, crianças de 0 a 3 anos, além de dados referentes ao aprendizado adequado no $3^{\circ}$ ano do Ensino Fundamental - quando os alunos devem estar plenamente alfabetizados, segundo as metas e, ainda, dados referentes ao fluxo escolar, por meio da taxa de distorção idade-série, que indica o percentual de alunos fora do ano escolar correto para a sua idade.

O próximo capítulo irá apresentar os dados referentes ao nível meso de análise. 


\section{A DESIGUALDADE DE CONHECIMENTO: nível meso de análise}

Caracterizando-se como o menor estado da região sudeste em termos populacionais, o Espírito Santo possuía,em 2010, segundo dados do IBGE/2011, uma população de 3.514.952, com estimativa de 3.885.049 pessoas para o ano de 2014. Sua população está distribuída numa área de $46.096,925 \mathrm{~km}^{2}$ em 78 municípios agrupados em 10 microrregiões de gestão administrativa. É o quarto menor estado do Brasil, maior apenas que Sergipe, Alagoas e Rio de Janeiro.Sua capital é o município de Vitória, e sua cidade mais populosa o município de Serra, o que faz do Espírito Santo o único estado do Brasil no qual a capital não é a maior cidade.Além disso, os dados da PNAD/IBGE 2009 informam que a população economicamnete ativa (PEA) urbana era de 1.540 .469 e a rural de 356.025 .

Segundo o Programa das Nações Unidas para o Desenvolvimento PNUD/2010, o índice de desenvolvimento humano municipal (IDHM) do Espírito Santo é de 0,74 , o $7^{\circ}$ no ranking nacional. O IDHM ${ }^{14}$ é formado a partir de três

\footnotetext{
${ }^{14} \mathrm{O}$ Índice de Desenvolvimento Humano Municipal (IDHM) é uma medida composta de indicadores de três dimensões do desenvolvimento humano: longevidade, educação e renda. O índice varia de 0 a 1 e quanto mais próximo de 1, maior o desenvolvimento humano. O IDHM brasileiro segue as mesmas três dimensões do $\mathrm{IDH}$, adequando a metodologia global ao contexto brasileiro e à disponibilidade de indicadores nacionais. Os componentes do IDHM agregamas 3 das mais importantes dimensões do desenvolvimento humano: a oportunidade de viver uma vida longa e saudável, de ter acesso ao conhecimento e ter um padrão de vida que garanta as necessidades básicas, representadas pela saúde, educação e renda. Vida longa e saúdável é medida pela expectativa de vida ao nascer, calculada por método indireto a partir dos dados dos Censos Demográficos do IBGE. Esse indicador mostra o número médio de anos que as pessoas viveriam a partir do nascimento, mantidos os mesmos padrões de mortalidade observados no ano de referência. Acesso a conhecimento é medido pela composição de indicadores de escolaridade da população adulta e do fluxo escolar da população jovem. A escolaridade da população adulta é medida pelo percentual de pessoas de 18 anos ou mais de idade com fundamental completo; e tem peso 1 . O fluxo escolar da população jovem é medido pela média aritmética do percentual de crianças entre 5 e 6 anos frequentando a escola, do percentual de jovens entre 11 e 13 anos frequentando os anos finais do ensino fundamental $\left(6^{\circ}\right.$ a $9^{\circ}$ ano), do percentual de jovens entre $15 \mathrm{e}$ 17 anos com ensino fundamental completo e do percentual de jovens entre 18 e 20 anos com ensino médio completo; e tem peso 2. A medida acompanha a população em idade escolar em quatro momentos importantes da sua formação. A média geométrica desses dois componentes resulta no IDHM Educação. Os dados são do Censo Demográfico do IBGE. Padrão de vida é medido pela renda municipal per capita, ou seja, a renda média de cada residente de determinado município. É a soma da renda de todos os residentes, dividida pelo número de pessoas que moram no município - inclusive crianças e pessoas sem registro de renda. Os dados são do Censo Demográfico do IBGE. Os três componentes acima são agrupados por meio da média geométrica, resultando no IDHM.
} 
componentes: IDHM longevidade, IDHM educação e IDHM renda. O Espírito Santo obteve o índice de 0,83 para o componente longevidade (IDHM-L) considerado um valor muito alto; 0,65 para o componente educação (IDHM-E), índice considerado médio e 0,74 para o componente renda (IDHM-R), considerado um índice alto.

Assim como a educação dos demais estados brasileiros, o sistema educacional do Espírito Santo é formado por quatro redes de ensino: federal, municipal e estadual - que juntas compõem a educação pública - e a rede particular. Os dados da tabela 27apresentam o percentual de matrículas e de escolas de cada rede de ensino.

\section{Tabela 27: Percentual de matrícula por rede de ensino (2014) - Espírito Santo}

\begin{tabular}{lcccc}
\hline $\begin{array}{c}\text { Etapa da } \\
\text { escolarização }\end{array}$ & Federal & Estadual & Municipal & Particular \\
\hline Creche & 0,13 & 0 & 89,58 & 10,29 \\
Pré-escola & 0,05 & 0 & 87,97 & 11,97 \\
EF AnosIniciais & 0 & 14,66 & 72,99 & 12,36 \\
EF AnosFinais & 0 & 31,83 & 56,1 & 12,07 \\
EM & 5,88 & 78,06 & 0,05 & 16,01 \\
\hline Fonte: Elaboração própria a partir dos dados do Qedu
\end{tabular}

A rede escolar do Espírito Santo atende a aproximadamente $30 \%$ da população de 0 a 3 anos, sendo que a grande maioria das escolas/creches que recebem essas crianças são da rede municipal. $\mathrm{O}$ mesmo acontece no atendimento das crianças de 4 a 5 anos (pré-escola). No ensino fundamental, a taxa de matrícula líquida está praticamente universalizada e seu atendimento se dá prioritariamente pela rede municipal, mas há oferta da rede estadual e particular. Nos anos finais, há um percentual significativo de matrículas na rede estadual, que não chega a superar a taxa de atendimento da rede municipal. Já no ensino médio, é a rede estadual a principal responsável pela oferta de vagas, sendo a oferta desta etapa na rede municipal quase nula. Assim, são as redes públicas municipais e estaduais as principais responsáveis pela oferta de vagas na educação básica.

Desde 2008, o estado do Espírito Santo avalia longitudinalmente a fase da escolarização referente à alfabetização, aplicando testes cognitivos em leitura, 
escrita e matemática aos alunos do $1^{\circ}, 2^{\circ}$ e $3^{\circ}$ anos do ensino fundamental. Com este desenho, é possível não apenas monitorar a evolução do desempenho dos estudantes ano a ano, como também verificar as variações dos desempenhos entre as escolas e as turmas. É possível, portanto, observar os dois componentes do conceito de eficácia escolar: valor agregado e equidade (MURILLO, 2003).

O quadro 5 apresenta a média de desempenho em leitura e escrita (após o controle por ISE) dos10926 alunos que realizaram as quatro avaliações e o nível correspondente no padrão de desempenho definidopelo PAEBES-Alfa.O desempenho dos alunos é medido por meio de uma escala com valores de 0 a 1000 pontos. Essa escala é dividida em quatro níveis de desempenho: abaixo do básico, básico, proficiente e avançado. O anexo 2 apresenta a interpretação pedagógica de cada nível. Cada domínio da alfabetização possui uma escala que foram padroizadas de forma a garantir a comparabilidade dos dados.

\section{Quadro 6: Média do desempenho por domínio da alfabetização - PAEBES- Alfa}

\begin{tabular}{|l|c|c|c|c|}
\hline Avaliação & $\begin{array}{c}\text { Média do } \\
\text { desempenho } \\
\text { em leitura }\end{array}$ & $\begin{array}{c}\text { Nível de } \\
\text { desempenho }\end{array}$ & $\begin{array}{c}\text { Média do } \\
\text { desempenho } \\
\text { em escrita }\end{array}$ & $\begin{array}{c}\text { Nível de } \\
\text { desempenho }\end{array}$ \\
\hline $\begin{array}{l}\text { Av } 1-1^{\circ} \\
\text { ano }(2012- \\
\text { entrada })\end{array}$ & 460,96 & Básico & 463,51 & Básico \\
\hline $\begin{array}{l}\text { Av } 2-1^{\circ} \\
\text { ano }(2012- \\
\text { saída })\end{array}$ & 606,90 & Avançado & 604,95 & Avançado \\
\hline $\begin{array}{l}\text { Av } 3-2^{\circ} \\
\text { ano (2013) }\end{array}$ & 674,05 & Proficiente & 674,52 & Proficiente \\
\hline $\begin{array}{l}\text { Av 4 - } 3^{\circ} \\
\text { ano (2014) }\end{array}$ & 734,94 & Proficiente & 732,67 & Proficiente \\
\hline
\end{tabular}

No ano de 2014, o desempenho médio dos alunos do $3^{\circ}$ ano do Espírito Santo no PAEBES-Alfa corresponde ao nível proficiente, tanto no domínio da leitura quanto na escrita. Esses dados estão em consonância com os dados da ANA, uma vez que, na avaliação nacional, tem-se um percentual relativamente alto de alunos do $3^{\circ}$ ano, em 2014, com aprendizado adequado em leitura $(85,14 \%)$ e escrita $(72,05 \%)$. 
O gráficolapresenta o valor agregado em cada onda de avaliação, após controle pelo índice socioeconômico dos alunos. Observa-se que há um ganho de aprendizagem $^{15}$ muito grande entre a primeira (entrada no $1^{\circ}$ ano) e a segunda avaliação (saída no $1^{\circ}$ ano): 145,94 pontos de média de desempenho agregado para leitura e 141,44 pontos para escrita. Por outro lado, entre a segunda (fim do $1^{\circ}$ ano) e a terceira avaliação (fim do $2^{\circ}$ ano), o valor agregado é bem menor, tanto em leitura quanto em escrita: 67,15 e 69,57 pontos, respectivamente. Por fim, o valor agregado à média de desempenho entre a terceira (fim do $2^{\circ}$ ano) e a quarta avaliação (fim do $3^{\circ}$ ano), é ainda menor: 60,89 pontos para leitura e 58,15 pontos para escrita.

\section{Gráfico 1: Valor agregado pelas escolas - PAEBES-Alfa}

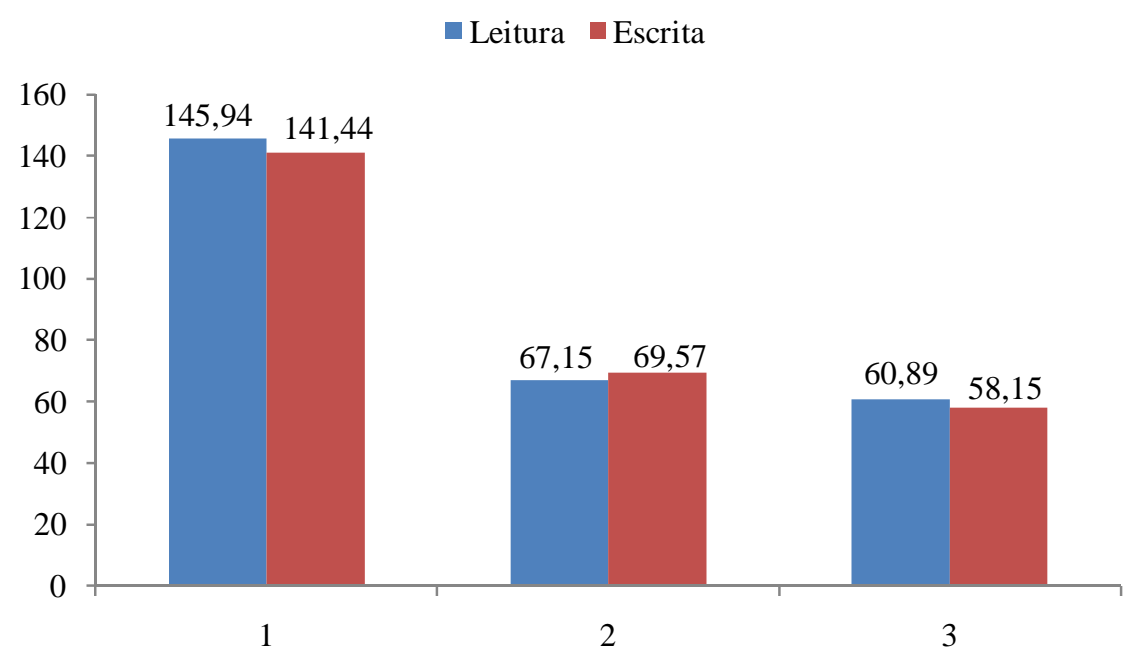

Fonte: Elaboração própria a partir dos dados do PAEBES-Alfa

Portanto, o maior ganho de aprendizagem se dá no $1^{\circ}$ ano do ensino fundamental. Nos anos seguintes, o valor agregado pela escola ao aprendizado dos alunos é significativamente menor.

Os testes cognitivos de Língua Portuguesa são formados por vinte questões: 17 referentes à leitura e 3 à escrita.Para cada avaliação, são construídos

\footnotetext{
${ }^{15}$ Para o cálculo do valor agregado, o desempenho de leitura e escrita foram padronizados, ou seja, foram colocados na mesma esala. Desta forma, nas quatro ondas de avaliação para os dois domínio de conhecimento, a média do desempenho é aproximadamente 0 e o desvio-padrão 1, permitindo a comparabilidade dos resultados.
} 
80 itens que são agrupados em cadernos, sendo que as questões podem compor mais de um caderno.

A elaboração dos itens é feita por profissionais da área de alfabetização e cada item avalia uma habilidade específica do processo de alfabetização (ver anexo 1). Os itens também possuem calibração, de forma que eles são alocados numa escala que mensura seu grau de dificuldade. Desta forma, os cadernos são compostos por itens fáceis, medianos e difíceis que avaliam diversas habilidades da alfabetização.

\subsection{A análise dos percentuais de acerto dos itens nos testes}

Para ser justa e eficaz, uma escola deve garantir não apenas a igualdade de oportunidades e de tratamento, mas também e, principalmente, a igualdade dos conhecimentos de base, ou universais (CRAHAY, 2002). Ou seja, a despeito da origem social dos alunos, todos devem aprender de forma satisfatória os conhecimentos de base.

Uma forma possível de verificar se o conhecimento adquirido pelos estudantes é satisfatório e igualitário, é analisar o percentual de acerto dos itens dos testes cognitivos, bem comosua variação. Desta maneira, se o item tiver um alto percentual de acerto, isso indica que a habilidade avaliada pelo item está aquirida e consolidada pela maioria dos alunos. Por outro lado, se o item tiver um baixo percentual de acerto, isso indica que poucos alunos adquiriram aquela habilidade avaliada. Se a variação desse percentual entre as turmas for alta, isso signifca que, no interior da escola, a aquisição da habilidade é desigual e se a variação for pequena, o aprendizado da habilidade é mais homogêneo ou mais igualitário.

Quando se analisam os percentuais de acerto dos itens de uma avaliação educacional, um problema que se coloca é a instabilidade das medias, uma vez que elas dependem diretamente do desempenho dos alunos. Desta forma, duas situações são possíveis: uma em que um determinado item tenha média de acerto próxima a $100 \%$, revelando a existência de um estado de consolidação da aprendizagem por todos os estudantes, e outra em que o percentual de acerto de um item tenha média de acerto 0 ou próxima de 0 (especialmente quando 
corrigidos para o acerto casual). Nesta última situação, o percentual de acerto nulo ou quase nulo indica que a habilidade mensurada no item possa ter sido tratada pelo professor de forma inadequada ou que sequer tenha sido trabalhada com os estudantes em sala de aula.No PAEBES-Alfa, essa imprecisão foi tratada por meio de uma medida denominada parâmetro $B^{16}$, que indica o grau de dificuldade do item. Uma mesma habilidade pode ser mensurada por um item fácil e outro difícil e o percentual de acerto de cada um desses itens revelará o grau de complexidade com que os alunos dominam determinado conhecimento.

Antes de analisar os percentuais de acerto dos itens, dois procedimentos estatísticos foram realizados. O primeiro foi a correção para o acerto casual. As médias de desempenho em uma avaliação em larga escala são estimadas a partir dos dados das respostas dos alunos aos itens dos testes, variáveis estas que possuem uma codificação binária, onde o valor nulo corresponde ao erro e o valor unitário, ao acerto. No teste de leitura, todos os itens eram de múltipla escolha, com quatro opções de resposta. Com esta configuração, é significativa a probabilidade de acerto (25\%), mesmo que o respondente não possua os conhecimentos necessários para se acertar o item. Para atenuar este problema na interpretação das médias dos percentuais de acerto, utilizou-se um procedimento para a correção do acerto casual, dado pela seguinte fórmula:

$$
\text { Perc_corrigido }=\text { Perc_real }-\left(100-P e r c \_r e a l\right) /(N-1)
$$

onde:

\footnotetext{
${ }^{16} \mathrm{O}$ parâmetro B é a medida do grau de dificuldade do item. Essa medida é uma escala quefoi divida em quatro partes, de forma a classificar os itens com grau de dificuldade alto, médio e baixo, de acordo com o quadro abaixo. Os itens considerados difíceis são aqueles que fazem parte do quartil 4.
}

\begin{tabular}{|c|c|c|c|}
\hline \multicolumn{4}{|c|}{ Divisão do parâmetro B em quartis } \\
\hline $\begin{array}{c}\text { Grau de } \\
\text { dificuldade }\end{array}$ & Quartil & $\begin{array}{c}\text { Escala do parâmetro B } \\
(10 \text { ano })\end{array}$ & $\begin{array}{c}\text { Escala do parâmetro B } \\
\text { (3o ano) }\end{array}$ \\
\hline Baixo & Quartl 1 & De 182,14 a 393,35 & De 293,89 a 540,09 \\
\hline \multirow{2}{*}{ Médio } & Quartil 2 & 393,36 a 465,80 & 540,10 a 624,21 \\
\cline { 2 - 4 } & Quartil 3 & 465,81 a 529,65 & 624,22 a 715,08 \\
\hline Alto & Quartil 4 & Acima de 529,66 & Acima de 715, 09 \\
\hline
\end{tabular}


Perc_corrigido: percentual esperado corrigido do item para o acerto casual

Perc_real: percentual esperado bruto de acerto do item

$N$ : número de opções da múltipla escolha para o item específico.

Nas avaliações do PAEBES-Alfa, são sempre quatro as opções de resposta de cada item de leitura. Assim, a equação acima ficou:

$$
\text { Perc_corrigido }=\text { Perc_real }-\left(100-P e r c \_r e a l\right) / 3
$$

Desta forma, um item que, por exemplo, tenha tido $25 \%$ de acerto esperado bruto, ficaria com um percentual nulo de acerto corrigido:

$$
\text { Perc_corrigido }=25-(100-25) / 3=25-75 / 3=25-25=0
$$

Mas, se por acaso, o item teve um percentual esperado bruto de acerto inferior a $25 \%$, pela fórmula, o seu respectivo percentual corrigido seria negativo. Para evitar esse valor impossível, optou-se por, nessas situações, atribuir um percentual nulo para tais itens.Por outro lado, caso um item tivesse $100 \%$ de acerto bruto, o seu percentual esperado corrigido assumiria este mesmo valor, ou seja, 100.Portanto, os percentuais corrigidos de acerto aqui considerados são todos valores capazes de variar entre 0 e 100 .

O segundo procedimento foi o controle do percentual de acerto dos itens pelas características socioeconômicas dos alunos, no qual foram incorporados na estimação dos percentuais de acerto, os efeitos de algumas variáveis do nível do aluno que, conforme amiúde se demonstra na literatura, encontram-se costumeiramente associadas de forma significativa ao desempenho escolar, tal como o nível ou índice sócio-econômico do aluno ou de sua respectiva família (XAVIER, F.; ALVES, M., 2015), sua cor/raça (SOARES, J.; ALVES, M., 2003) e também o seu gênero (CARVALHO, M. 2003).

Esse controle estatístico foi realizado por meio de modelos de regressão hierárquicaem dois níveis: aluno e escola. Para cada item, foi modelada uma regressão que, por meio dos coeficientes de fidedignidade, mostrava a significância estatística de cada variável sobre o percentual de acerto. As fórmulas a seguir ilustram o modelo: 
Nível 1 (aluno):

$\mathrm{LOG}(\mathrm{AC})_{i j}=\beta_{0 j}+\beta_{1 j}(\mathrm{ISE})+\beta_{2 j}(\mathrm{BRANCO})+\beta_{3 j}(\mathrm{FEM})+e_{i j}$

onde as variáveis são:

LOG(AC): logaritmo natural da chance de acerto Pde um aluno $i$, estudando na escola $j$, possui, em relação a um determinado item;

ISE: índice socio-econômico do aluno ${ }^{17}$

BRANCO: cor do aluno ( $0=$ não-branco, $1=$ branco)

FEM: gênero do aluno $(0=$ masculino, $1=$ feminino $)$

e os coeficientes são:

$\beta_{0 j}$ : percentual médio do logaritmo da chance de acerto dos alunos da escola $j$ de acertarem um determinado item, controlando-se pelo seu respectivo índice sócioeconômico, cor e gênero.

$\beta_{1 j}, \beta_{2 j}, \beta_{3 j}$ correspondem respectivamente aos coeficientes de regressão para o índice sócio-econômico, a cor e o gênero dos alunos na escola $j$.

$e_{i j}$ : erro estocástico da medida do aluno.

Já no nivel 2 (da escola), as equações ficam como:

$\beta_{0 j}=\gamma_{0 j}+u_{0 j}$

$\beta_{1 j}=\gamma_{1 j}+u_{1 j}$

$\beta_{2 j}=\gamma_{2 j}+u_{2 j}$

$\beta_{3 j}=\gamma_{3 j}+u_{3 j}$

onde os coeficientes $\gamma$ correspondem às médias totais das variáveis já mencionadas, e os coeficientes $u$, aos respectivos erros aleatórios de cada escola avaliada.

17 O ISE foi construído com base nos itens do questionário contextual aplicado aos pais/responsáveis dos alunos dos $1^{\circ}(2012), 2^{\circ}$ (2013) e $3^{\circ}$ (2014) anos do ensino fundamental. Os itens que compõem o índice são: escolaridade dos pais, situação de trabalho, quantidade de livros (não escolares) em casa, frequência com que realiza leituras e acesso a bens e serviços (rua asfaltada, energia elétrica, água na torneira, coleta de lixo, benefício do bolsa família, empregada doméstica/faxineira, banheiro em casa, rádio, TV em cores, geladeira, máquina de lavar roupa, aparelho de DVD, automóvel (carro/moto), computador, dicionário de Língua Portuguesa/outras línguas). 
Percebe-se, portanto, que, no nível da escola, o modelo é incondicional, visto que não há variáveis explicativas para suas respectivas equações. O modelo incondicional tem como propósito verificar a pertinência de uma análise hierárquica, pois identifica a variação do impacto de cada nível sobre o percentual de acerto do item e se essa variação é significativa. O modelo incondicional foi elaborado para observar a variação do percentual de acerto dos itens no nível da escola, após o controle das variáveis sociais (ISE, cor/raça e sexo) no nível do aluno.

Dessa forma, foi possível estimar os percentuais de acerto de cada item do PAEBES-Alfa, controlados pelas três variáveis já mencionadas no nível do aluno.

Esse modelo de regressão foi rodado para todos os 160 itens (80 itens da avaliação de entrada no $1^{\circ}$ ano e 80 itena da avaliação de saída no $3^{\circ}$ ano). Entretanto, as variáveis sociais não apresentaram significância estatística em alguns itens, o que exigiu a elaboração de outras modelagens. Após a realização de inúmeros testes, obtiveram-seoito modelos para os itens do $1^{\circ}$ ano e nove modelos para os itens do $3^{\circ}$ ano. Vinte itens no $1^{\circ}$ ano e nove itens no $3^{\circ}$ ano não foram controlados pelas variáveis sociais, pois elas não foram estatisticamente significativas para explicar o percentual de acerto. Os demais itens foram controlados pelas variáveis sociais, conforme explicitado no quadro do anexo 3 . Após realizado o controle estatístico, procedeu-se à análise dos dados.

Foram analisadas um total de 349 escolas e 1168 turmas. As escolas foram caracterizadas como homogêneas e heterogêneas segundo o desempenho médio das turmas. Desta forma, consideraram-se escolas homogêneas em que todas as turmas tinham baixo desempenho médio; homogêneas em que todas as turmas tinham alto desempenho médio e heterogêneas em que as turmas possuíam médias de desempenho variados. O quadro 7 ilustra essa categorização:

Quadro 7: Categorização das escolas em homogêneas/heterogêneas

\begin{tabular}{|c|l|c|c|}
\hline Escolas & \multicolumn{1}{|c|}{ Turmas } & $\begin{array}{c}\text { Número } \\
\text { de escolas } \\
\left(1^{\circ} \text { ano }\right)\end{array}$ & $\begin{array}{c}\text { Número } \\
\text { de escolas } \\
\left(3^{\circ} \text { ano }\right)\end{array}$ \\
\hline \multirow{2}{*}{ Homogêneas } & $\begin{array}{l}\text { Todas as turmas com baixo } \\
\text { desempenho médio (quartil 1) }\end{array}$ & 130 & 96 \\
\cline { 2 - 4 } & $\begin{array}{l}\text { Todas as turmas com alto desempenho } \\
\text { médio (quartil 3) }\end{array}$ & 60 & 90 \\
\hline
\end{tabular}




\begin{tabular}{|c|l|c|c|}
\hline Heterogêneas & $\begin{array}{l}\text { Turmas com médias de desempenho } \\
\text { variadas (quartil 1, 2 e 3) }\end{array}$ & 159 & 163 \\
\hline Total & 349 & 349 \\
\hline
\end{tabular}

Fonte: Elaboração própria a partir dos dados do PAEBES-Alfa

O primeiro passo foi a agregação dos itens por escolas para a análise longitudinal da correlação entre as médias do percentual de acerto e a média do desvio-padrão por escola.

Conforme mostra o gráfico 2 , no $1^{\circ}$ ano, a correlação ${ }^{18}$ dessas duas medidas émuito fraca, de apenas $26 \%$.Embora a correlação não seja muito significativa, a sutil inclinação da reta indica a tendência de que quanto maior é o percentual de acerto numa escola, maior será a variação desse percentual entre as turmas, evidenciando certa heterogeneidade das turmas.

\section{Gráfico 2: Correlação entre o percentual de acerto dos itens e sua variação - $1^{\circ}$ ano do Ensino Fundamental}

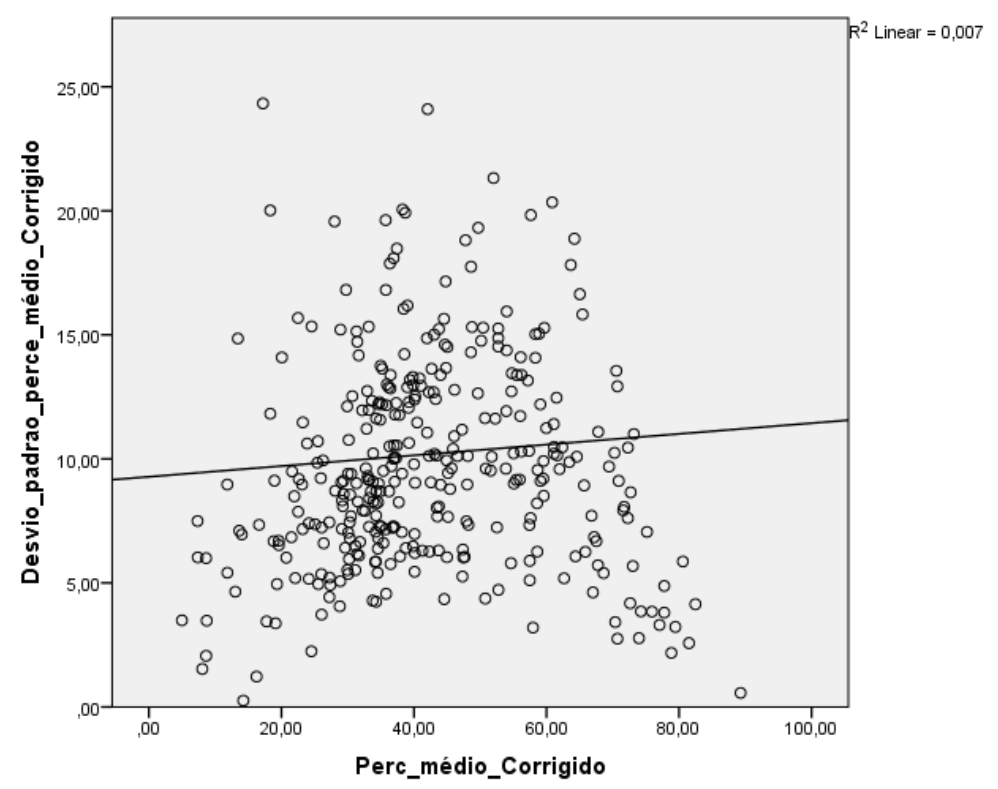

Fonte: Elaboração própria a partir dos dados do PAEBES-Alfa

No $3^{\circ}$ ano, a correlação entre essa duas medidas é, de 59\%. De acordo com a inclinação da reta, quanto maior o percentual de acerto dos itens de uma escola, menor é a variação (desvio padrão) desse percentual entre as turmas. Isso significa que as turmas são mais homogêneas no $3^{\circ}$ do que no $1^{\circ}$ ano.

${ }^{18}$ A correlação de Pearson é calculada por meio da raiz quadrada do $\mathrm{R}^{2}$. 


\section{Gráfico 3: Correlação entre o percentual de acerto dos itens e sua variação - $3^{\circ}$ ano do Ensino Fundamental}

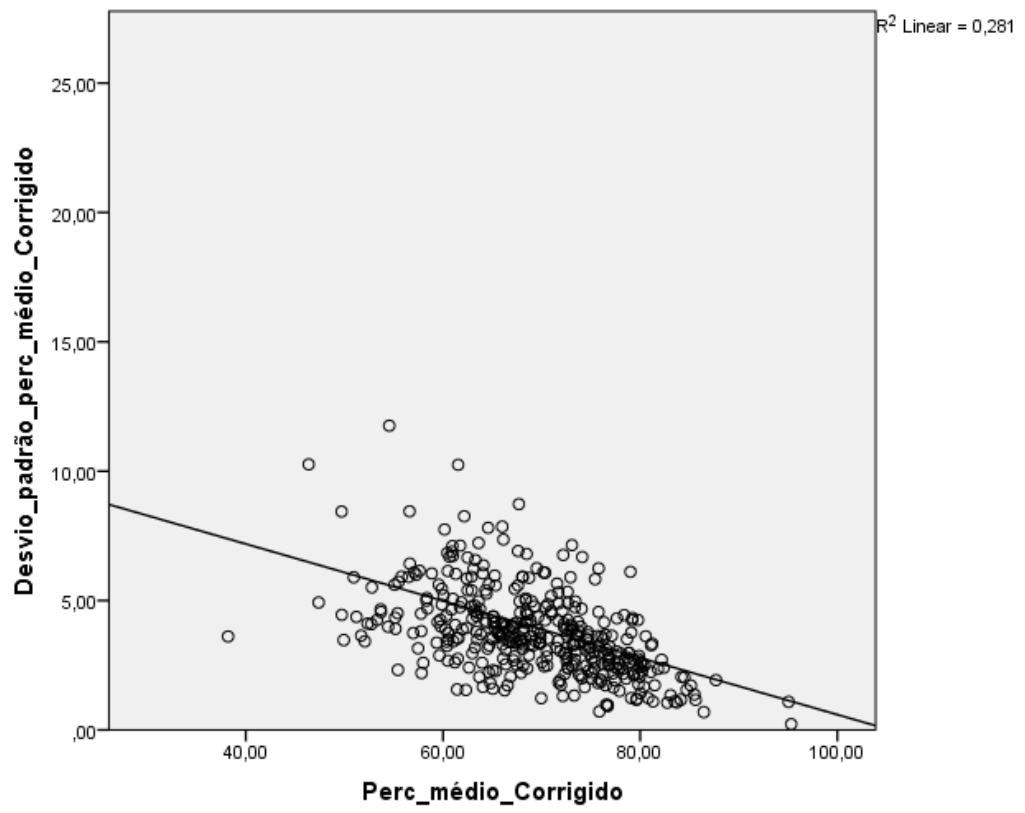

Fonte: Elaboração própria a partir dos dados do PAEBES-Alfa

Tem-se portanto, dois resultados importantes:

1) De acordo com o quadro 5, no início do $1^{\circ}$ ano, o nível de desempenho dos estudantes era básico. No final do $3^{\circ}$ ano, era proficiente. Ou seja, após o controle dos efeitos socioeconômicos, o resultado mostra que as escolas conseguiram agregar valor ao aprendizado dos alunos, de forma que eles conseguiram alcançar um aprendizado satisfatório no final do ciclo de alfabetização.

2) Como visto nos gráficos 2 e 3 , no $1^{\circ}$ ano, as turmas eram mais heterogêneas, ou seja, quanto maior o percentual de acerto, maior a variação desse percentual. No $3^{\circ}$ ano, a inclinação da reta muda de direação, o que indica que as turmas, ao longo desse período, passaram por algumas modificações, de forma que elas se tornaram mais homogêneas. Ou seja, quanto maior o percentual de acerto, menor a sua variação entre as turmas. 
No recorte temporal abordado, este resultado não corrobora a ideia de que as desigualdades educacionais no inicio da escolarização se acentuam ao longo da trajetória escolar (DUBET, 2004). Pelo contrário, esses dados mostram que, no período referente ao ciclo de alfabetização, a escola consegue agregar valor ao aprendizado dos estudantes, ao mesmo tempo em que torna a aquisição das habilidades intraescolares - ou seja, entre as turmas - mais homogêneas, ou, em outras palavras, mais igualitárias. Os dados apontam para uma diminuição da desigualdade de conhecimento especificamente entre as turmas e entre as escolas. Para se verificar se as desigualdades entre as escolas se amplificam ou diminuemtorna-se necessário fazer a análise no nível da escola. Nesse estudo, a análise foi feita para o nível da turma e revela que a desigualdade de conhecimento diminui entre as turmas dos $1^{\circ}$ e $3^{\circ}$ anosdo Ensino Fundamental.

Os gráficos 4 e 5 apresentam a correlação entre o percentual de acerto e o grau de dificuldade do item. No $1^{\circ}$ ano, essa correlação é altamente significativa, de $79 \%$, e a inclinação da reta indica que quanto maior o parâmetro B, ou seja, quanto mais difícil for o item, menor é o percentual de acerto.No $3^{\circ}$ ano, a correlação dessas duas medidas émoderada, de 54\%, mas a inclinação da reta tem a mesma direção, indicando, portanto, que quanto maior é a dificuldade do item, menor é o percentual do acerto. 
Gráfico 4: Correlação entre o percentual de acerto dos itens e seu grau de dificuldade $-1^{\circ}$ ano do Ensino Fundamental

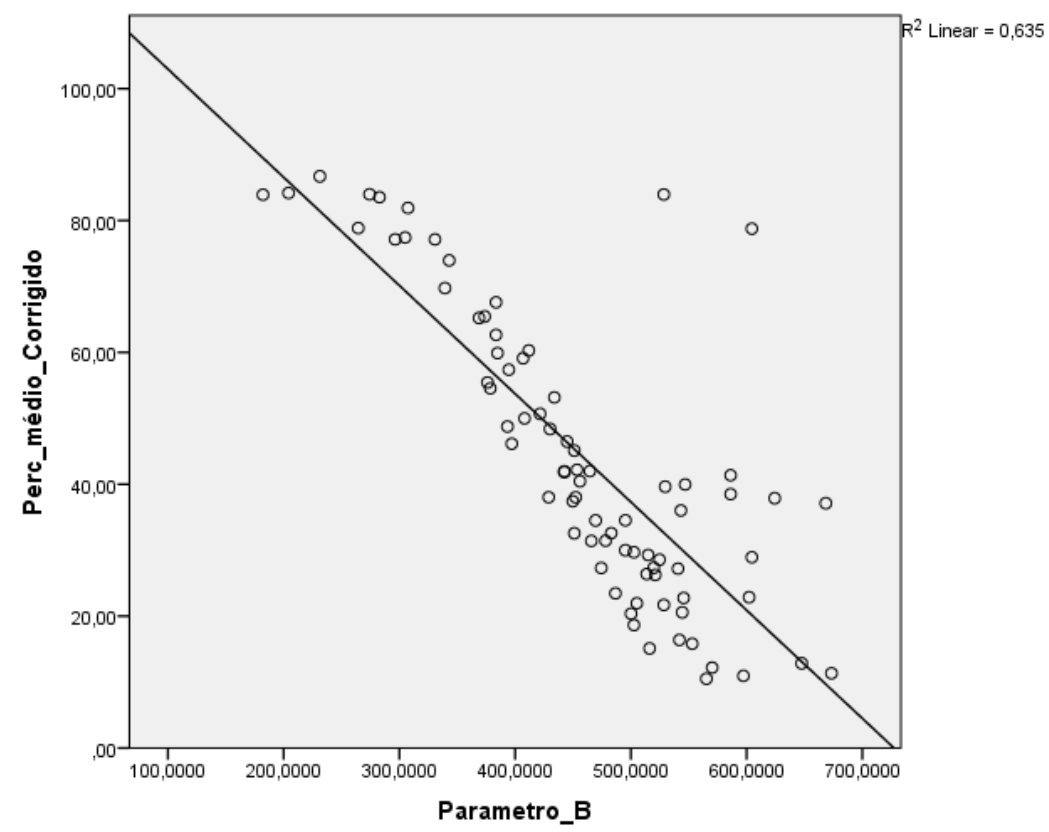

Fonte: Elaboração própria a partir dos dados do PAEBES-Alfa

Gráfico 5: Correlação entre o percentual de acerto dos itens e seu grau de dificuldade $-3^{\circ}$ ano do Ensino Fundamental

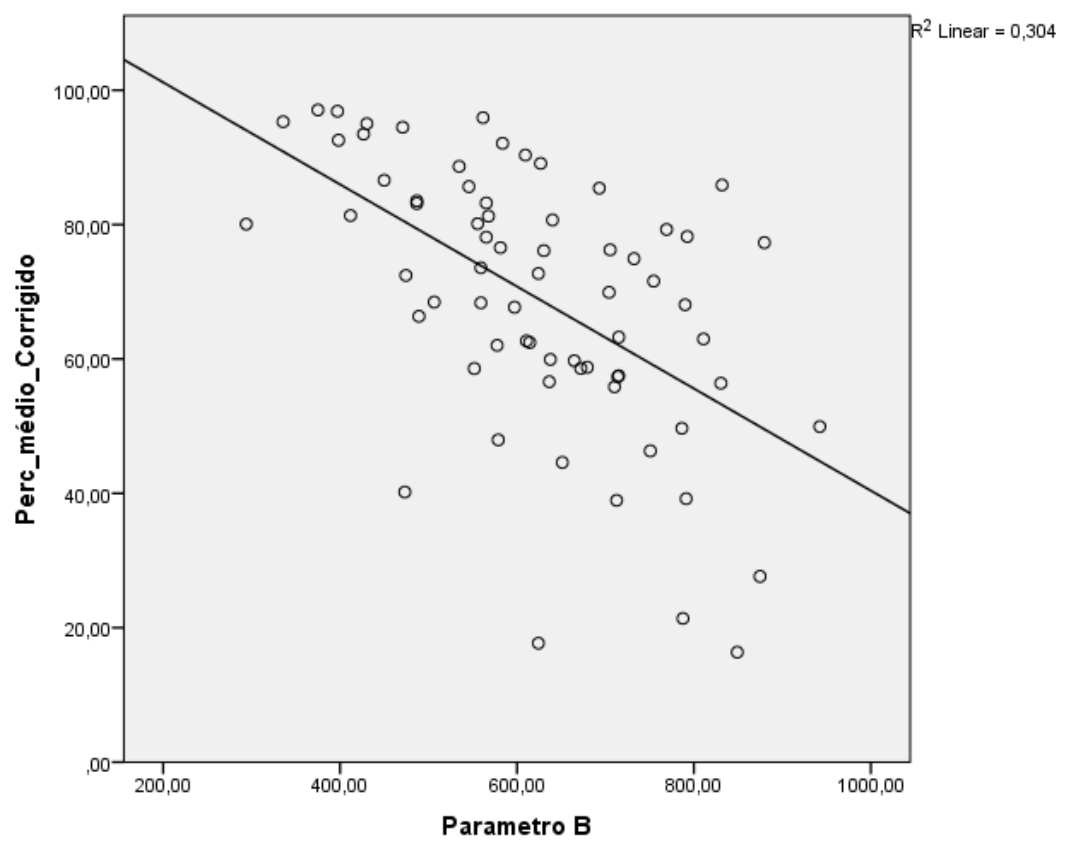

Fonte: Elaboração própria a partir dos dados do PAEBES-Alfa 
Já a variação do percentual de acerto no $1^{\circ}$ ano é moderamente correlacionado com o grau de dificuldade do item, sendo a correlação de 50\%.A inclinação da reta mostra que quanto maior é a dificuldade do item, maior é a variação do seu percentual de acerto entre as turmas. Isso significa que há uma maior desigualdade entre as turmas segundo o grau de dificuldade do item. No $3^{\circ}$ ano, a correlação entre essas duas medidas é menor, de $40 \%$ e, assim como acontece no $1^{\circ}$ ano, a inclinação da reta mostra que quanto maior é o grau de dificuldade do item, maior é a variação do percentual de acerto entre as turmas.Esse resultado evidencia que quando se trata de uma habilidade com elevado grau de complexidade, a aquisição dessa habilidade é mais desigual, pois a variação do percentual de acerto é maior. Ou seja, há maior heterogeidade do aprendizado de habilidades complexas no interior da escola.

De forma suscinta, os dados revelam que 1) poucos alunos consolidaram o aprendizado de habilidades complexas; 2) o aprendizado de habilidades complexas se dá de forma desigual no interior das escolas.

\section{Gráfico 6: Correlação entre a variação do percentual de acerto dos itens e seu grau de dificuldade $-\mathbf{1}^{\circ}$ ano do Ensino Fundamental}

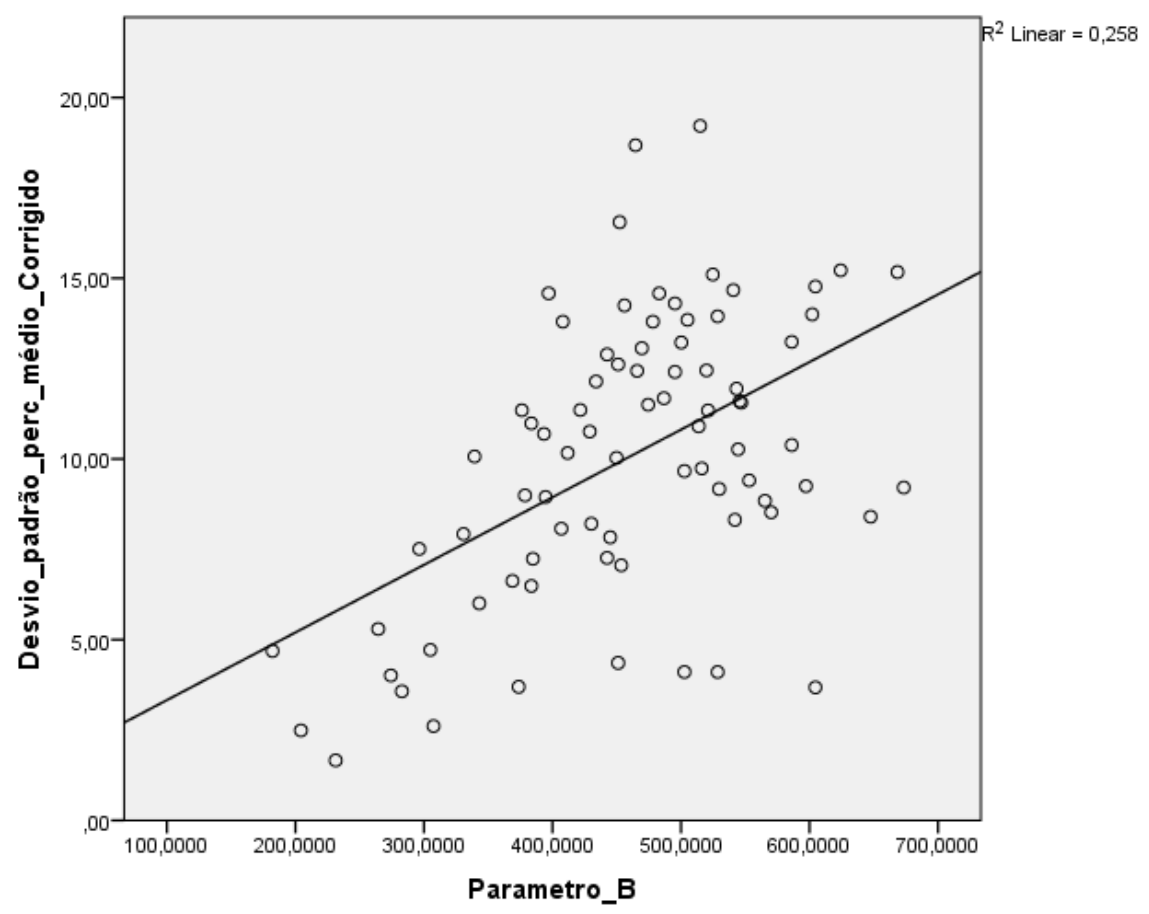

Fonte: Elaboração própria a partir dos dados do PAEBES-Alfa 


\section{Gráfico 7: Correlação entre a variação do percentual de acerto dos itens e seu grau de dificuldade $-3^{\circ}$ ano do Ensino Fundamental}

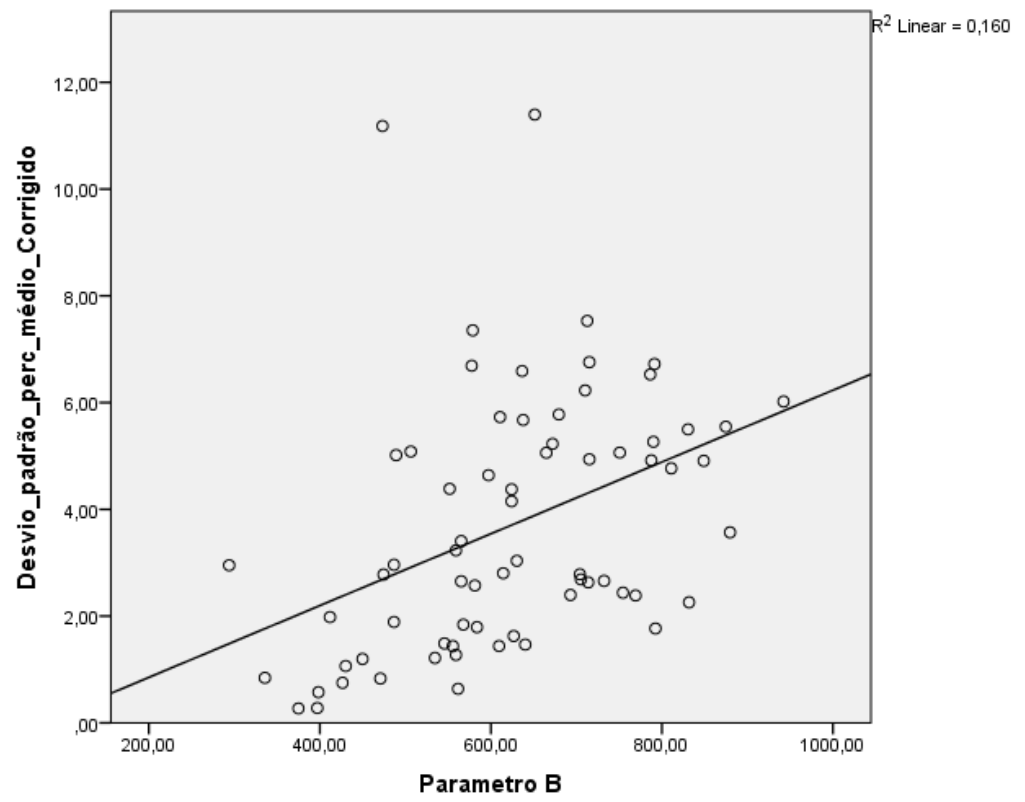

Fonte: Elaboração própria a partir dos dados do PAEBES-Alfa

Quando se analisa o conjunto total das habilidades avaliadas, a escola consegue agregar valor ao aprendizado e, ao mesmo tempo, promover um aprendizado mais igualitário.Entretanto, quando se eleva o grau de complexidade de uma determinada habilidade avaliada, o percentual de acerto do item é pequeno e sua variação é alta. Em outras palavras: poucos alunos adquirem aprendizagens complexas e essa aquisição se dá de forma desigual no interior da escola.

A partir desses resultados mais gerais, buscou-se averiguar se as habilidades complexas (itens difíceis, ou seja, aqueles que pertencem ao quartil 4) seriam adquiridas segundo as características sociais clássicas - nível socioeconômico, raça/cor e sexo dos alunos.Para os itens difíceis tanto do $1^{\circ}$ ano quanto do $3^{\circ}$ ano, os resultados mostraram que não há efeito significativo das variáveis sociais sobre o percentual de acerto dos itens. Ou seja, a aquisição de habilidades complexas não se dá em função das características sociais dos alunos. $^{19}$

\footnotetext{
${ }^{19}$ Para verificar se as variáveis sociais explicam o percentual de acerto dos itens difíceis, utilizouse a regressão linear como técnica estatística.
} 
Em face desses resultados, complementamos a análise anterior utilizando o percentual de acerto dos itens difíceis e sua variação segundo o nível de desempenho das turmas, e considerando as habilidades avaliadas por esses itens. Implementamos o controle do efeito da composição social da escola, e baseamos as comparações no estudo do percentual de acertos de itens de teste difíceis de acordo com o parâmetro $B$, de modo a aumentar as chances de as diferenças entre os dois grupos de turmas refletirem o currículo efetivamente ensinado e suas semelhanças e diferenças de ênfase, quer se trate de um ou de outro grupo de turmas.

Por um lado, consideramos em nossa análise que o alto percentual de acerto de um item mostra que a habilidade avaliada foi dominada por praticamente todos os estudantes, e que este resultado evidenciaria a eficácia do trabalho da escola em garantir o aprendizado daquele conteúdo. Por outro lado, consideramos também que um item com baixo percentual de acerto, estaria a indicar que poucos alunos adquiriram a habilidade avaliada e, portanto, que a escola teria trabalhado de forma inadequada aquele conteúdo. Por sua vez, em termos da categoria igualdade de conhecimento que norteia este estudo, itens com alta variação do percentual de acerto entre as turmas, evidenciariam que a habilidade avaliada foi trabalhada de forma diferenciada entre os agrupamentos de turmas considerados no estudo, mesmo entre os itens que apresentam alta variação do percentual de acerto, mas para os quais a média desse percentual é baixa para as turmas de baixo e de alto desempenho.

Além disso, o fato de contar com resultados de uma avaliação longitudinal nos permitiu identificar as diferenças na evolução geral de aprendizagem entre os dois grupos de turmas e a composição dessas diferenças em termos de conteúdo curricular de leitura.

Nesse processo de análise, levamos em conta a matriz de referência em LínguaPortuguesa do PAEBES-Alfa (anexo 1) que é composta por cinco tópicos. Em cada tópico são apresentadas as competências, as habilidades, os níveis de complexidade das habilidades e os anos em que cada habilidade é avaliada. Embora a matriz do PAEBES-Alfa, como toda matriz de referência, represente apenas um recorte do currículo, relacionado ao que pode ser aferido por meio de testes padronizados tipicamente utilizados na avaliação em larga escala, ela 
apresenta importantes elementos relacionados às habilidades e competências a serem desenvolvidas na etapa da alfabetização. Isso permite a análise do percentual de acerto dos itens em cada ano e, portanto, a identificação da ênfase dada a diferentes dimensões do conteúdo curricular no processo de ensino e de aprendizagem relativo ao ciclo de alfabetização. Por meio dessa análise, que levou em conta o controle do efeito da composição social da escola, foi possível identificar as semelhanças e as diferenças de ênfase curricular em cada agrupamento de turmas.

\section{ANO DO ENSINO FUNDAMENTAL}

A partir deste ponto, apresentamos o percentual de acerto dos itens difícieis e sua variação segundo o nível de desempeno das turmas, além das habilidades avaliadas por esses itens.

$\mathrm{O}$ procedimento adotado para observar a igualdade de conhecimento (CRAHAY, 2002) entre as turmas, foi dividir o desempenho obtido pelas turmas em alto, médio e baixo. Os dados analisados referem-se somente às turmas de alto e baixo desempenho e a análise consiste em tentar observar se as habilidades complexas são adquiridas de forma homogênea ou heterogênea entre os dois agrupamentos de turmas.

O Quadro 8 apresenta o percentual de acerto, a diferença do percentual de acerto entre as turmas de alto e baixo desempenho e a habilidade avaliada pelo item e está ordenado de forma decrescente, segundo a coluna que indica a diferença do percentual de acerto entre os dois agrupamentos.

\section{Quadro 8: Percentual de acerto e variação dos itens difíceis por nível de desempenho $-1^{\circ}$ ano do EF}

\begin{tabular}{|c|c|c|c|c|}
\hline Item & $\begin{array}{c}\text { Nivel de } \\
\text { Desempenho }\end{array}$ & $\begin{array}{l}\% \text { de } \\
\text { acerto }\end{array}$ & $\begin{array}{c}\text { Diferença do } \\
\text { percentual } \\
\text { de acerto entre } \\
\text { os dois grupos }\end{array}$ & Habilidade \\
\hline \multirow{2}{*}{$\mathrm{P} 42$} & Baixo & 18,11 & \multirow{2}{*}{46,47} & \multirow{2}{*}{$\begin{array}{l}\text { Identificar o número de sílabas de uma palavra } \\
\text { (consciência silábica). }\end{array}$} \\
\hline & Alto & 64,58 & & \\
\hline \multirow{2}{*}{ P72 } & Baixo & 3,11 & \multirow{2}{*}{40,87} & \multirow{2}{*}{ Reconhecer a finalidade de gêneros diversos. } \\
\hline & Alto & 43,98 & & \\
\hline
\end{tabular}




\begin{tabular}{|c|c|c|c|c|}
\hline \multirow{2}{*}{ P66 } & Baixo & 2,62 & \multirow{2}{*}{39,22} & \multirow{2}{*}{ Distinguir, como leitor, diferentes tipos de letras. } \\
\hline & Alto & 41,84 & & \\
\hline \multirow{2}{*}{ P61 } & Baixo & 3,40 & \multirow{2}{*}{39,15} & \multirow{2}{*}{$\begin{array}{l}\text { Ler frases e pequenos textos, localizando } \\
\text { informações explícitas contidas neles. }\end{array}$} \\
\hline & Alto & 42,55 & & \\
\hline \multirow{2}{*}{ P67 } & Baixo & 13,82 & \multirow{2}{*}{34,90} & \multirow{2}{*}{$\begin{array}{l}\text { Identificar o número de sílabas de uma palavra } \\
\text { (consciência silábica). }\end{array}$} \\
\hline & Alto & 48,73 & & \\
\hline \multirow{2}{*}{ P63 } & Baixo & 23,21 & \multirow{2}{*}{34,10} & \multirow{2}{*}{$\begin{array}{l}\text { Reconhecer o local de inserção de determinada } \\
\text { palavra numa sequência em ordem alfabética }\end{array}$} \\
\hline & Alto & 57,31 & & \\
\hline \multirow{2}{*}{ P68 } & Baixo & 0,00 & \multirow{2}{*}{33,23} & \multirow{2}{*}{$\begin{array}{l}\text { Ler frases e pequenos textos, localizando } \\
\text { informações explícitas contidas neles. }\end{array}$} \\
\hline & Alto & 33,23 & & \\
\hline \multirow{2}{*}{ P80 } & Baixo & 24,97 & \multirow{2}{*}{32,68} & \multirow{2}{*}{ Identificar assunto de textos. } \\
\hline & Alto & 57,65 & & \\
\hline \multirow{2}{*}{ P64 } & Baixo & 8,54 & \multirow{2}{*}{32,32} & \multirow{2}{*}{$\begin{array}{c}\text { Localizar informações explícitas em textos de } \\
\text { maior extensão ou em textos que apresentam } \\
\text { dados. }\end{array}$} \\
\hline & Alto & 40,85 & & \\
\hline \multirow{2}{*}{ P75 } & Baixo & 1,13 & \multirow{2}{*}{31,63} & \multirow{2}{*}{ Identificar assunto de textos. } \\
\hline & Alto & 32,76 & & \\
\hline \multirow{2}{*}{ P34 } & Baixo & 30,22 & \multirow{2}{*}{30,65} & \multirow{2}{*}{ Identificar elementos que constroem a narrativa. } \\
\hline & Alto & 60,87 & & \\
\hline \multirow{2}{*}{ P58 } & Baixo & 31,75 & \multirow{2}{*}{30,40} & \multirow{2}{*}{$\begin{array}{l}\text { Localizar informações explícitas em textos de } \\
\text { maior extensão ou em textos que apresentam } \\
\text { dados. }\end{array}$} \\
\hline & Alto & 62,15 & & \\
\hline \multirow{2}{*}{ P71 } & Baixo & 0,85 & 2585 & Reconhecer o local de inserção de determinada \\
\hline & Alto & 26,71 & 25,85 & palavra numa sequência em ordem alfabética \\
\hline P57 & Baixo & 31,40 & 2404 & Identificar qâneros teytuais divercos \\
\hline PJ/ & Alto & 56,34 & 24,94 & Identiticar generos textuais diversos. \\
\hline & Baixo & 2,07 & & \\
\hline P69 & Alto & 26,28 & 24,20 & Reconhecer a finalidade de gêneros diversos. \\
\hline P73 & Baixo & 1,19 & 2389 & Identificar elementos gue constroem a narrativa \\
\hline 573 & Alto & 25,08 & 25,09 & Identimcar elementos que constroem a narrativa. \\
\hline P62 & Baixo & 3,98 & 2306 & Reconhecer o local de inserção de determinada \\
\hline $\mathrm{POL}$ & Alto & 27,04 & 25,00 & palavra numa sequência em ordem alfabética \\
\hline P14 & Baixo & 75,73 & 620 & Identificar sílabas e sons (consciência silábica e \\
\hline P14 & Alto & 81,93 & 0,20 & consciência fonêmica). \\
\hline
\end{tabular}

Fonte: Elaboração própria a partir dos dados do PAEBES-Alfa

Em geral, podemos dizer que os itens avaliados no $1^{\circ}$ ano foram difíceis para as turmas de baixo desempenho e médios para as de alto desempenho. Isso pode ser percebido nas diferenças nos valores do percentual de acerto entre esses dois grupos que variam, na maioria dos casos, entre $47 \%$ e $25 \%$. Também pode ser percebido nos valores dos percentuais de acerto de muitos deles que se situam, 
no grupo das turmas de alto dsempenho, acima de $60 \%$. Somente no caso do item $\mathrm{P} 14$, que avalia habilidade relacionada à consciência silábica e fonêmica, a diferença dos percentuais de acerto dos dois grupos de turmas decresce consideravelmente, apenas ultrapassando a casa dos $6 \%$.

Uma ressalva importante sobre estas diferenças é queos itens mostrados no quadro 7 fizeram parte da avaliação dos alunos no início do $1^{\circ}$ ano. Isto significa que os resultados apresentados ainda não conseguem refletir o trabalho das escolas e dos professores. O mais provável é que esses resultados sejam produto do background familiar e/ou da frequência prévia desses alunos à Educação Infantil. De qualquer forma, o percentual de acerto dos itens no $1^{\circ}$ ano foi incluído neste estudo por considerá-lo útil para o estudo tanto da aprendizagem agregada pela escola como da evolução da variação dessas aprendizagens das turmas entre o iníco do $1^{\circ}$ e o fim do $3^{\circ}$ ano.

Como pode ser observado ainda no quadro 8, nos dois itens (P68 e P61) que avaliam a habilidade de ler frases e pequenos textos, localizando informações explícitas, opercentual de acerto,entre as turmas com baixo desempenho é nulo ou não ultrapassa os 3,4\%, revelando que os alunos não possuem a habilidade avaliada pelo item. Nas turmas de alto desempenho,os percentuais de acerto desses dois itens foram, respectivamente, de $33,23 \%$ e de $42,55 \%$, o que indica que mais de 1/3 dos alunos dessas turmas já apresentavam essa habilidade ao iniciarem o $1^{\circ}$ ano escolar.Também pode ser observado que entre as turmas de baixo desempenho, nos itens P75 (identificar assunto de textos), P71, P62 (reconhecer o local de inserção de determinada palavra numa sequência em ordem alfabética), P73 (identificar elementos que constroem a narrativa) e P69, P72 (reconhecer a finalidade de gêneros diversos), ospercentuaisde acerto mal se aproximam de3\%, indicando que os alunos dessas turmas não possuem a habilidade avaliada. Já entre os alunos das turmas de alto desempenho, o percentual de acerto desses mesmos itens oscila entre $25 \%$ e $32 \%$. No entanto, é na habilidade de identificar o número de sílabas de uma palavra,que foi avaliada pelos itens P42 e P67, que a variação do percentual de acerto entre as turmas de alto e baixo desempenho égrande. No item P42 esses grupos de turmas têm, respectivamente, $64,58 \%$ e $18,11 \%$, de acertos e o item P67 tem 48,73\% e $13,11 \%$, respectivamente. A variação do acerto entre as turmas de alto e baixo 
desempenho é de $46,47 \%$ no item P42 e de 34,90\% no item 67. Essa grande variação de acerto confirma a desigualdade de conhecimento presente no âmbito intraescolar no $1^{\circ}$ ano.

Como se trata de um resultado inesperado, foi analisado o ajuste desses itens ao teste. Verificou-se que ambos estão ancorados no padrão de desempenho avançado e a correlação bisserial ${ }^{20}$ é de 0,465 (item P42) e 0,446 (P67), o que indica que eles discriminam bem os alunos que dominam a habilidade daqueles que ainda não a dominam, confirmam o bom ajuste do item ao teste e informam que os alunos que mais acertaram no teste, também acertaram esses itens.

O gráfico 8 ilustra essas diferenças.

\footnotetext{
${ }^{20}$ A correlação bisserial é um dado estatístico que indica o ajuste do item ao teste. O ajuste do item ao teste é considerado bom quando a correlação bisserial assume um avlor supeior a 0,30. Itens que possuem uma correlação bisserial abaixo de 0,30 são itens que não discriminam bem os alunos que dominam a habilidade avaliada daqueles que não a dominam e indicam o ajuste inadequado do item ao teste.
} 


\section{Gráfico 8: Percentual de acerto dos itens difíceis por turmas - 10 ano}

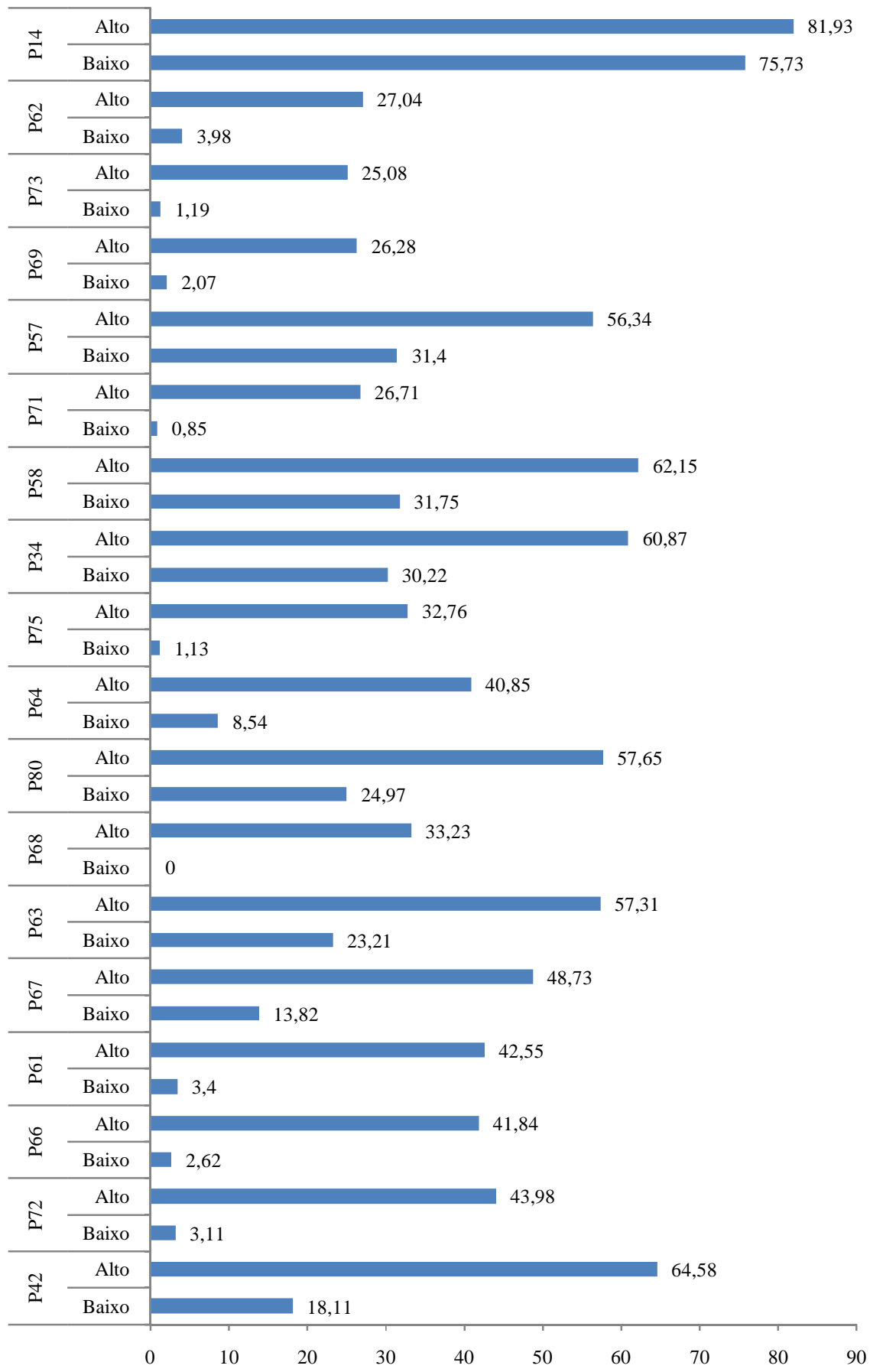

Fonte: Elaboração própria a partir dos dados do PAEBES-Alfa

Em síntese, as habilidades 1) reconhecer a finalidade de gêneros diversos, 2) distinguir, como leitor, diferentes tipos de letras, 3) ler frases e pequenos 
textos, localizando informações explícitas, 4) identificar o número de sílabas de uma palavra (consciência silábica) e 5) reconhecer o local de inserção de determinada palavra numa sequência em ordem alfabética se configuram como aquelas que apresentam maior desigualdade entre as turmas do $1^{\circ}$ ano do Ensino Fundamental.

O item P64 (localizar informações explícitas em textos de maior extensão ou em textos que apresentam dados) utilizado na avaliação de entrada no $1^{\circ}$ ano (2012), foi o único divulgado pelo PAEBES-Alfa, viabilizando, assim, sua interpretação pedagógica. O item está ancorado no padrão de desempenho avançado ea correlação bisserialé alta, de 0,524, indicando que este item discrimina bem os alunos que dominam a habilidade daqueles que não a dominam e que o ajuste do item ao teste é bom. A correlação bisserial também indicaque os alunos que mais acertaram no teste também acertaram esse item.

Figura 1: Item P64

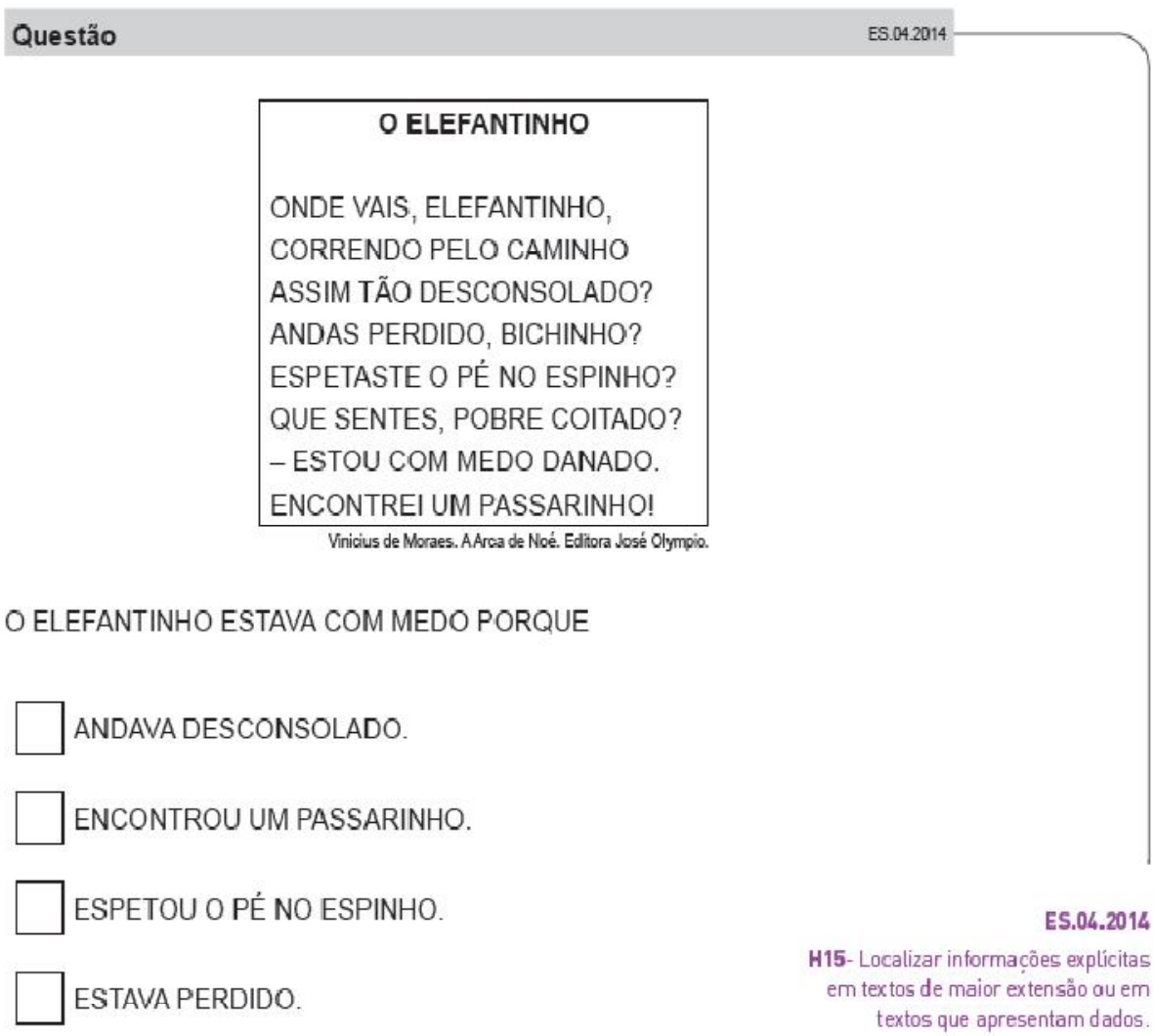


Conforme pode ser observado na figura 1, este item exige a identificação de informação dada explicitamente, sobre o encontro do protagonista com outro personagem, em um poema infantil, gênero textual comumente abordado nos anos iniciais do Ensino Fundamental. Alunos que têm experiência na escola com a leitura de poemas reconhecem a estrutura organizacional desse gênero e fatos ficcionais que transcorrem com as personagens. Para realizar a tarefa proposta com êxito, o estudante deve inferir a causa de um evento, que, no caso, é o medo do passarinho.A habilidade avaliadadiz repeito à evolução dos eventos, que leva à relação de causa e consequência: qual fato dá origem a outro fato. No caso, é o medo do passarinho que faz com que o elefantinho tenha um passo apressado, andar perdido, ar desconsolado.O conectivo porque -marca linguística de uma relação de causa - não está marcado no poema, o que exige do aluno a habilidade de fazer inferências. Entretanto, ele está presente no comando, o que torna mais clara a relação de causa e consequência. Também é possível observar que é relativamente pouco provável que os alunos no início do primeiro ano escolar avaliados compreendam o uso do sinal gráfico travessão na redação de diálogos.

O item apresenta baixo índice de acerto no grupo de baixodesempenho $(8,54 \%)$, sugerindo que a grande maioria dos participantes do teste que se encontram nessas turmas não domina a habilidade avaliada. Entre as turmas com maior desempenho, esse percentual foi de (40,85\%), indicando que, provavelmente, nesse grupo, apesar da diferença de 32,32\% entre os dois grupos, a maioria dos alunos das turmas com alto desempenho também não domina a habilidade avaliada em sua completude.

\section{ANO DO ENSINO FUNDAMENTAL}

O quadro 9 apresenta os mesmos dados para o $3^{\circ}$ ano do ensino fundamental. Neste ano, os resultados dos alunos dos testes já conseguem refletir o trabalho das escolas e dos professores, ao longo do período destinado à alfabetização. 


\section{Quadro 9: Percentual de acerto e variação dos itens difíceis por nível de desempenho $-3^{\circ}$ ano do $\mathbf{E F}$}

\begin{tabular}{|c|c|c|c|c|}
\hline Item & $\begin{array}{c}\text { Nível de } \\
\text { Desempenho }\end{array}$ & $\begin{array}{l}\% \text { de } \\
\text { acerto }\end{array}$ & $\begin{array}{l}\text { Diferença do } \\
\text { percentual } \\
\text { de acerto entre } \\
\text { os dois grupos } \\
\end{array}$ & Habilidade \\
\hline \multirow{2}{*}{64} & Baixo & 11,69 & \multirow{2}{*}{14,39} & \multirow{2}{*}{$\begin{array}{l}\text { Identificar o número de sílabas de uma palavra } \\
\text { (consciência silábica). }\end{array}$} \\
\hline & Alto & 26,09 & & \\
\hline \multirow{2}{*}{72} & Baixo & 47,45 & \multirow{2}{*}{14,18} & \multirow{2}{*}{$\begin{array}{l}\text { Estabelecer relações de continuidade temática, a partir da } \\
\text { recuperação de elementos da cadeia referencial do texto. }\end{array}$} \\
\hline & Alto & 61,63 & & \\
\hline \multirow{2}{*}{51} & Baixo & 38,34 & \multirow{2}{*}{12,65} & \multirow{2}{*}{ Identificar assunto de textos. } \\
\hline & Alto & 50,99 & & \\
\hline \multirow{2}{*}{52} & Baixo & 45,62 & \multirow{2}{*}{12,25} & \multirow{2}{*}{ Reconhecer a finalidade de gêneros diversos. } \\
\hline & Alto & 57,87 & & \\
\hline \multirow{2}{*}{79} & Baixo & 33,82 & \multirow{2}{*}{12,10} & \multirow{2}{*}{ Inferir informações implícitas em textos } \\
\hline & Alto & 45,92 & & \\
\hline \multirow{2}{*}{62} & Baixo & 56,42 & \multirow{2}{*}{11,21} & \multirow{2}{*}{$\begin{array}{l}\text { Identificar o efeito de sentido decorrente do uso de } \\
\text { recursos gráficos, da pontuação, da seleção lexical e } \\
\text { repetições. }\end{array}$} \\
\hline & Alto & 67,63 & & \\
\hline \multirow{2}{*}{70} & Baixo & 44,63 & \multirow{2}{*}{9,28} & \multirow{2}{*}{ Identificar efeitos de humor em textos diversos. } \\
\hline & Alto & 53,91 & & \\
\hline \multirow{2}{*}{65} & Baixo & 9,07 & \multirow{2}{*}{9,17} & \multirow{2}{*}{$\begin{array}{l}\text { Identificar marcas linguísticas que evidenciam o } \\
\text { enunciador no discurso direto ou indireto. }\end{array}$} \\
\hline & Alto & 18,23 & & \\
\hline \multirow{2}{*}{32} & Baixo & 66,19 & \multirow{2}{*}{8,71} & \multirow{2}{*}{ Identificar gêneros textuais diversos. } \\
\hline & Alto & 74,90 & & \\
\hline \multirow{2}{*}{48} & Baixo & 52,18 & 860 & Identificar o efeito de sentido decorrente do uso de \\
\hline & Alto & 60,80 & 8,02 & 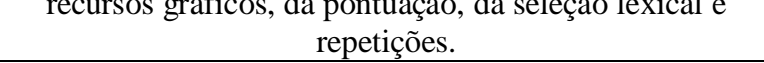 \\
\hline & Baixo & 69,69 & & Identificar o efeito de sentido decorrente do uso de \\
\hline 29 & Alto & 78,21 & 8,53 & $\begin{array}{l}\text { recursos grafıcos, da pontuaçao, da seleçao lexıcal e } \\
\text { repetiçôes. }\end{array}$ \\
\hline $62 .>3$ & Baixo & 23,41 & 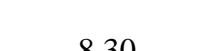 & nolidode de ĝ̂ner \\
\hline 03 & Alto & 31,71 & 8,50 & Keconnecer a finalidade de generos diversos. \\
\hline 25 & Baixo & 72,81 & 783 & Identificar assunto de textos \\
\hline $2 \mathrm{~J}$ & Alto & 80,63 & 1,05 & Identincal assumto de textos. \\
\hline 45 & Baixo & 63,42 & 732 & Estabelecer relações lógico discursivas presentes no \\
\hline 45 & Alto & 70,74 & 1,32 & texto \\
\hline 57 & Baixo & 56,42 & 688 & Localizar informações explícitas em textos de maior \\
\hline$J$ & Alto & 63,30 & 0,00 & extensão ou em textos que apresentam dados. \\
\hline 71 & Baixo & 81,24 & 623 & Identificar oêneros textuais diversos \\
\hline 11 & Alto & 87,48 & 0,25 & raentincar generos textuals arversos. \\
\hline 78 & Baixo & 48,95 & 581 & Identificar efeitos de humor em textos diversos \\
\hline 10 & Alto & 54,76 & $J, 01$ & 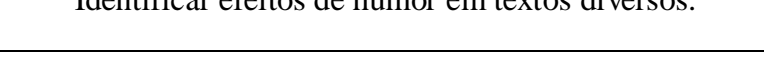 \\
\hline 30 & Baixo & 59,49 & 560 & Localizar informações explícitas em textos de maior \\
\hline 30 & Alto & 65,08 & J,00 & extensão ou em textos que apresentam dados. \\
\hline
\end{tabular}




\begin{tabular}{|c|c|c|c|c|}
\hline \multirow{2}{*}{60} & Baixo & 54,90 & \multirow{2}{*}{5,50} & \multirow{2}{*}{ Inferir informações implícitas em textos } \\
\hline & Alto & 60,40 & & \\
\hline \multirow{2}{*}{66} & Baixo & 76,00 & \multirow{2}{*}{5,37} & \multirow{2}{*}{$\begin{array}{l}\text { Localizar informações explícitas em textos de maior } \\
\text { extensão ou em textos que apresentam dados. }\end{array}$} \\
\hline & Alto & 81,37 & & \\
\hline \multirow{2}{*}{47} & Baixo & 83,42 & \multirow{2}{*}{4,87} & \multirow{2}{*}{$\begin{array}{l}\text { Estabelecer relações lógico discursivas presentes no } \\
\text { texto. }\end{array}$} \\
\hline & Alto & 88,28 & & \\
\hline \multirow{2}{*}{77} & Baixo & 76,31 & \multirow{2}{*}{3,74} & \multirow{2}{*}{ Reconhecer a finalidade de gêneros diversos. } \\
\hline & Alto & 80,05 & & \\
\hline \multirow{2}{*}{56} & Baixo & 68,48 & \multirow{2}{*}{3,40} & \multirow{2}{*}{$\begin{array}{c}\text { Estabelecer relações lógico discursivas presentes no } \\
\text { texto. }\end{array}$} \\
\hline & Alto & 71,88 & & \\
\hline \multirow{2}{*}{36} & Baixo & 38,46 & \multirow{2}{*}{2,94} & \multirow{2}{*}{$\begin{array}{l}\text { Localizar informações explícitas em textos de maior } \\
\text { extensão ou em textos que apresentam dados. }\end{array}$} \\
\hline & Alto & 41,40 & & \\
\hline
\end{tabular}

Fonte: Elaboração própria a partir dos dados do PAEBES-Alfa

A observação do quadro 9 permite perceber que a variação do percentual de acerto entre as turmas de baixo e alto desempenho é significativamente menor que no $1^{\circ}$ ano, oscilando entre uma diferença máxima de $14,39 \%$ e uma diferença mínima de acerto de $2,94 \%$. Isso significa que, no início do $1^{\circ}$ ano do ensino fundamental, havia mais desigualdade na aquisição de habilidades de leitura entre as turmas. Outra observação importante é que os percentuais de acerto nos dois grupos de turmas aumentam, em relação aos resultados do $1^{\circ}$ ano, ultrapassando na maioria das vezes o percentual de $60 \%$ e aproximando-se em alguns deles da casa de 80\%, em ambos os grupos.Por exemplo, nos itens P25 (identificar assuntos de textos), P47 (estabelecer relações lógico-discursivas presentes no texto), P66 (localizar informações explícitas em textos de maior extensão ou em textos que apresentam dados), P71(identificar gêneros textuais diversos) e P77 (reconhecer a finalidade de gêneros diversos), o percentual de acerto está acima de $70 \%$ para os dois grupos de desempenho, indicando que as habilidades avaliadas por esses itens foram aquiridas pela maioria dos alunos independentemente da turma frequientada, ao longo dos anos iniciais do ensino fundamental.

É possível observa, ainda, que o item P36, que avalia a habliidade de localizar informações explícitas em textos de maior extensão ou em textos que apresentam dados, é o que apresenta a menor variação do percentual de acerto $(2,94 \%)$, e que esse percentual não é muito alto nas turmas de baixo e de alto desempenho $(38,46 \%$ e $41,40 \%$, respectivamente). 
Já o item P64, que avalia a habilidade de identificar o número de sílabas de uma palavra, tem a maior variação do percentual de acerto e esse valor é muito baixo para os dois grupos $(11,69 \%$ nas turmas de baixo desempenho e $26,09 \%$ nas de alto desempenho). Isto revela que poucos alunos possuem essa habilidade, apesar de não apresentar a maior variação entre os dois grupos. Novamente realizamos a análisedo ajuste do item ao teste e verificamos que esse item apresenta uma correlação bisserial de 0,474, indicando que ele está bem ajustado ao teste, que discrimina bem os alunos que dominam a habilidade daqueles que não a dominam e que os alunos que mais acertaram no teste também acertaram esse item.

Considerando que os testes foram aplicados no final do $3^{\circ}$ ano do Ensino Fundamental - etapa escolar que os alunos deveriam estar planamente alfabetizados, segundo orientações do PNE - a habilidade de identificar número de sílabas de uma palavra já deveria estar dominada por todos os alunos. Entretanto, como podemos constatar a partir dos dados, esta habilidade, que é trabalhada pelos professores desde o $1^{\circ}$ ano do ciclo de alfabetização, ainda não foi consolidada por nenhum dos dois grupos, evidenciando que este conteúdo escolar não está sendo trabalhado adequadamente em sala de aula.

O gráfico 9 ilustra as informações do quadro 8, apresentando o percentual de acerto entre as turmas de alto e baixo desempenho. 
Gráfico 9: Percentual de acerto dos itens difíceis por turmas $-3^{\circ}$ ano

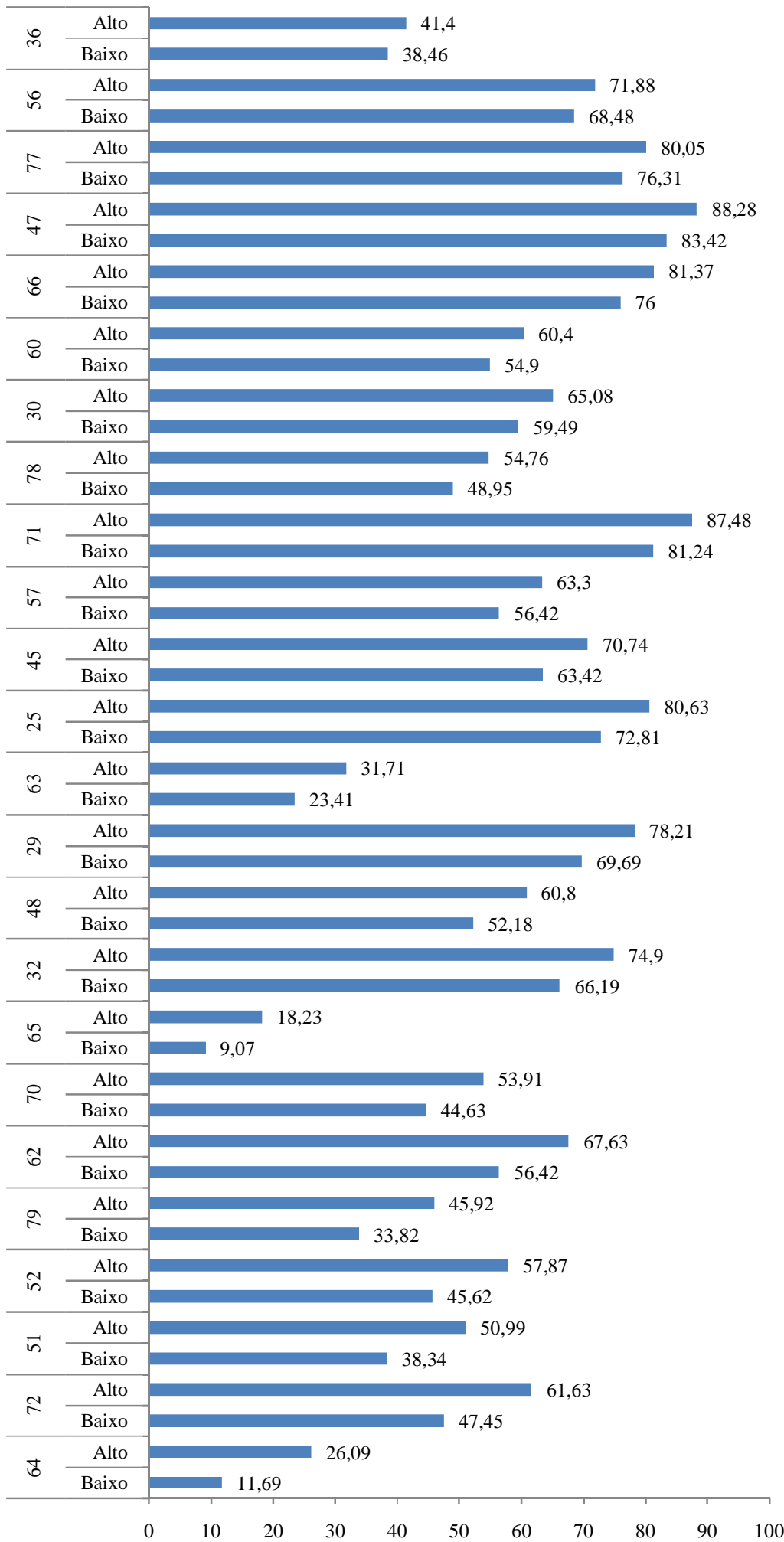

Fonte: Elaboração própria a partir dos dados do PAEBES-Alfa 
O item P65, utilizado na avaliação de saída no $3^{\circ}$ ano (2014), foi o único item difícil divulgado pelo PAEBES-Alfa, o que possibilita sua interpretação pedagógica. O item está ancorado no padrão de desempenho avançado e possui uma correlação bisserial alta, de 0,513 , indicando que este item discrimina bem os alunos que dominam a habilidade avaliada daqueles que não a dominam. Além disso, indica que os alunos que mais acertaram no teste acertaram também essa questão.

\section{Figura 2: Item P65}

\section{(P040052C2) Leia o texto abaixo.}

\section{De férias e ligado na natureza}

Quando a gente está de férias, não tem de acordar cedo, se preparar para as provas nem fazer lição de casa. Mas há uma tarefa que não podemos nos esquecer de jeito nenhum: cuidar bem da natureza.

\section{NA PRAIA}

- Não jogue embalagens no mar. Além de fazer a maior sujeira, elas podem matar animais.

\section{NA ESTRADA}

- Leve um saquinho para juntar o lixo. E não jogue nada pela janela do carro.

- Fale com seus pais para evitar viajar nas horas mais quentes do dia. Se o calor não estiver muito forte, peça a seus pais que desliguem o ar-condicionado e sigam viagem com as janelas abertas. $O$ ar-condicionado faz o carro gastar mais combustivel, o que causa mais poluição.

Disponivel em: Ahttp:/iplanetasustentavel.abril.com.oriplanetinhainatureza/conteudo_planetinha_479218.shtmb. Acesso em: 12 abr. 2011. Fragmento_(PD40052C2_SUP)

Esse texto foi escrito para

ambientalistas.

estudantes.

pais.

professores. 
Este item, conforme pode ser observado na figura 2, se relaciona com a habilidade de identificar marcas linguísticas que evidenciam o enunciador no discurso direto ou indireto. O item exige do respondenteinferir, a partir de pistas linguísticas ("lição de casa”, "está de férias”, "preparar para as provas”), a quem o texto se dirige, uma vez que os possíveis interlocutores não são mostrados.O item também avalia o uso social do texto, pois há uma finalidade e público especifícos, o que faz com que os alunos precisem desenvolver outras estratégias de leitura, para além das marcas linguísticas, para consiguir responder a questão com êxito.

Esse item teve um percentual de acerto de $9,07 \%$ e 18,23\% nas turmas de baixo e alto desempenho, respectivamente, com variação entre esses dois grupos de $9,17 \%$. As baixas taxas de acerto desse item permitem perceber que esta habilidade tem sido insuficientemente trabalhada ao longo dos três primeiros anos do ensino fundamental pelas escolas investigadas nesta pesquisa.

De maneira geral, e a modo de síntese, é possível dizer que no início do $1^{\circ}$ ano do ensino fundamental, o desempenho é mais heterogêneo entre as turmas, mas essa heterogeneidade vai diminuindo de forma que, no final do $3^{\circ}$ ano, os resultados escolares são mais homogêneos. Essa tendência também é observada quando se analisam, especificamente, os itens difíceis do PAEBES-Afa. Neste caso, quanto maior a dificuldade do item, maior a variação de acerto entre as turmas de alto e baixo desempenho nesses dois anos escolares. Apesar disso, essa variação entre os dois grupos de turmas é bem menor no $3^{\circ}$ ano quando comparada ao $1^{\circ}$ ano.

Apesar de a variação do desempenho ser menor entre as turmas no $3^{\circ}$ ano, algumas habilidades não foram plenamente aprendidas por nenhum dos dois grupos até o final do ciclo de alfabetização, visto que o percentual de acerto nas turmas de baixo e alto desempenho mostra-se inferior a 50\%, nos dois casos para um conjunto de habilidades conforme apresentadono quadro 10. 


\section{Quadro 10: Habilidades com baixo percentual de acerto nos dois anos escolares}

\begin{tabular}{|c|c|}
\hline $\mathbf{1}^{\circ}$ ano & $3^{\circ}$ ano \\
\hline $\begin{array}{l}\text { Identificar o número de sílabas de uma } \\
\text { palavra (consciência silábica) }\end{array}$ & $\begin{array}{l}\text { Identificar o número de sílabas de uma } \\
\text { palavra (consciência silábica) }\end{array}$ \\
\hline $\begin{array}{l}\text { Reconhecer a finalidade de gêneros } \\
\text { diversos }\end{array}$ & $\begin{array}{l}\text { Reconhecer a finalidade de gêneros } \\
\text { diversos }\end{array}$ \\
\hline $\begin{array}{l}\text { Localizar informações explícitas em } \\
\text { textos de maior extensão ou em textos } \\
\text { que apresentam dados }\end{array}$ & $\begin{array}{l}\text { Localizar informações explícitas em } \\
\text { textos de maior extensão ou em textos } \\
\text { que apresentam dados }\end{array}$ \\
\hline $\begin{array}{l}\text { Distinguir, como leitor, diferentes tipos } \\
\text { de letras }\end{array}$ & $\begin{array}{l}\text { Identificar marcas linguísticas que } \\
\text { evidenciam o enunciador no discurso } \\
\text { direto ou indireto }\end{array}$ \\
\hline $\begin{array}{l}\text { Ler frases e pequenos textos, } \\
\text { localizando informações explícitas }\end{array}$ & Inferir informações implícitas em textos \\
\hline \multicolumn{2}{|l|}{ Identificar assuntos de textos } \\
\hline \multicolumn{2}{|l|}{$\begin{array}{l}\text { Reconhecer o local de inserção de } \\
\text { determinada palavra numa sequência } \\
\text { em ordem alfabética }\end{array}$} \\
\hline $\begin{array}{l}\text { Identificar elementos que constrõem a } \\
\text { narrativa }\end{array}$ & \\
\hline
\end{tabular}

Trata-se claramente de habilidades básicas de leitura, cujos percentuais de acerto denotam que praticamente a maioria dos alunos começa e termina o ciclo de alfabetização sem dominá-las plenamente. Isto evidencia a incapacidade da escola de trabalhar de forma eficaz determinados aspectos curriculares ao mesmo tempo em que nivela por baixoo desempenho da maioria de seus alunos. 


\section{INVESTIGANDO AS ESCOLAS E AS TURMAS: nível micro de análise}

Este capítulo apresenta a investigação qualitativa realizada em quatro escolas municipais do estado do Espírito Santo, duas delas localizadas no município de Cariacica e duas no de Serra.

A coleta dos dados aconteceu no final do ano letivo de 2014. De acordo com o corte temporal da análise longitudinal desse estudo, nesse ano, as crianças estavam no $3^{\circ}$ ano do Ensino Fundamental. Assim, o estudo fez observações em salas de aula dessa etapa escolar e entrevistas com os professores das aulas observadas, com os pedagogos e diretores das escolas. As observações foram realizadas nos meses de outubro, novembro e dezembro. Nas escolas de Cariacica, foram realizadas três observações em cada sala de aula e nas escolas de Serra, por causa da proximidade do fim do ano letivo, as aulas foram obsevadas apenas duas vezes. No total foram feitas 34 observações.

As entrevistas aconteceram durante os horários de planejamento dos professores ou após as aulas. Na escola Tulipa e Lírio, haviam duas pedagogas, uma para cada turno. Nas escolas Rosa e Girassol, o primeiro segmento do Ensino Fundamental funcionava apenas no turno da tarde e, por isso, havia apenas uma pedagoga. No total foram realizadas 23 entrevistas, com 14 professoras, 6 pedagogos e 3 diretoras. A diretora da escola Rosa não foi entrevistada, pois ela não tinha horário disponível para conceder a entrevista. Durante as duas semanas de observações, ela esteve presente na escola apenas duas vezes, sempre justificando as ausências em razão de compromissos na Secretaria de Educação ou problemas de saúde.

\subsection{Sobre a seleção das escolas}

O desenho longitudinal do PAEBES-Alfa oferece quatro medidas de desempenho em Leitura,Escrita e Matemática, que permitem verificar o ganho de aprendizagem dos alunos ao longo dos três primeiros anos do Ensino Fundamental. O estudo, utilizou apenas as medidas de Leitura e Escrita, pois o foco do estudo foi a alfabetização. O corte temporal do estudo foi: 
- $1^{\mathrm{a}}$ medida: início do $1^{\mathrm{o}}$ ano do EF (2012);

- $2^{\mathrm{a}}$ medida: final do $1^{\mathrm{o}}$ ano do EF (2012);

- $\quad 3^{\mathrm{a}}$ medida: final do $2^{\circ}$ ano do EF (2013);

- $4^{\mathrm{a}}$ medida: final do $3^{\circ}$ ano do EF (2014).

As medidas de Leitura e Escritasão apresentadas pelo PAEBES-Alfa em escalas de desempenho diferente. Entretanto, é possível juntar as duas medidas, de forma a criar uma medida de Língua Portuguesa, que agrega numa mesma escala as duas dimensões da alfabetização e que foi utilizada apenas na escolha das escolas. A análise da evolução e da variação dos desempenhos entre as escolas e entre as turmas utilizou medidas desagregadas, observando os dados de Leitura e de Escrita separadamente.

Dois critérios foram utilizados para a seleção das escolas: 1) o valor agregado em termos de desempenho nas duas primeiras avaliações $\left(2012-1^{\circ}\right.$ ano e 2013 - $2^{\circ}$ ano); 2) número de turmas. Cada escola deveria ter no mínimo duas turmas para tornar possível a comparação dos desempenhos das turmas de uma mesma escola de forma a cotejar e a caracterizar a evolução desses resultados. A hipótese que fundamenta este esta parte da investigação leva em conta que as desigualdades de desempenho entre as turmas é maior que as desigualdades entre as escolas, pois há características das turmas - sobretudo àquelas relacionadas às práticas dos professores - que explicam parte significativa do desempenho e de sua variação, como já demonstrados por pesquisas anteriores (MACHADO SOARES,2003; BARBOZA, 2007; ALVES e FRANCO, 2008; BERNARDO, 2008; BARBOSA, 2011). 


\subsubsection{A escolha das escolas investigadas}

Com o intuito de investigar a desigualdade existente entre e dentro das escolas, o estudo selecionou quatro escolas que atenderam aos seguintes critérios $^{21}$ :

1) Ter participado da avaliação de 2012 ( $1^{\circ}$ ano: entrada e saída) e 2013 ( $2^{\circ}$ ano: saída);

2) Ter no mínimo 2 turmas;

3) Ter valor agregado em termos de média de desempenho no PAEBESAlfa;

4) Ser da rede pública - estadual ou municipal.

As escolas particulares foram excluídas da análise pois, entre as escolas participantes do PAEBES-Alfa, elas representavam um percentual de apenas $2,5 \%$.

Das 1081 escolas que realizaram as avaliações de entrada e saída em 2012 ( $1^{\circ}$ ano) e de saída em 2013 ( $2^{\circ}$ ano), apenas 221 escolas possuíam duas ou mais turmas, sendo 192 municipais, 23 estaduais e 6 particulares. O segundo filtro considerou o turno das turmas das escolas, ou seja, a seleção levou em consideração as escolas que possuíam turmas nos dois turnos (manhã e tarde) e/ou em um turno só. E, por fim, considerou também as redes de ensino, incluindo nesta etapa, as escolas particulares.

Os dados de 2014 não foram considerados na escolha das escolas, pois a seleção foi realizada em setembro daquele ano, ou seja, antes da aplicação da avaliação que acontece no mês de novembro. A realização da seleção das escolas antes da avaliação de 2014 deve-se à necessidade de se observar a escola e as salas de aula, bem como de fazer as entrevistas com os professores e diretores das escolas cujos alunos finalizaram o $3^{\circ}$ ano em 2014. Desta forma, foi possível obter dados quantitativos (produzidos pelo PAEBES-Alfa) e dados qualitativos (utilizando entrevista e observação) dos alunos, das escolas e das turmas no ano

\footnotetext{
${ }^{21}$ No momento em que a seleção das escolas foi realizada, o indicador de nível socioeconômico não estava disponível. Por esse motivo, a pesquisa não pode utilizar esse indicador como critério para a seleção das escolas. Posteriormente os dados foram disponibilizados e pôde-se fazer uma verificação, a posteriori do NSE das escolas.
} 
de 2014. Alinhar temporalmente os dados quantitativos aos dados qualitativos é importante para se ter uma análise comparativa melhor sintonizada com a realidade escolar.

O passo seguinte foi calcular a média do valor agregado pelas escolas no $1^{\circ}$ ano (desempenho na saída em 2012 - desempenho na entrada em 2012) e do $1^{\circ}$ para o $2^{\circ}$ ano (desempenho na saída em 2013 - desempenho na saída em 2012). Com este cálculo tem-se a média de desempenho que a escola agregou nestes dois períodos e fez-se a distribuição dessa média do valor agregado em quartis. $\mathrm{Ou}$ seja, dividiu-se a média de valor agregado das 221 escolas em 4 grupos, conforme a tabela a seguir. Assim, no início do $1^{\circ}$ ano (2012), as escolas estavam dividas da seguinte maneira: 55 escolas no quartil 1; 54 escolas no quartil 2; 57 escolas no quartil 3 e 55 escolas no quartil 4.No final do $1^{\circ}$ ano (2012), essas escolas estavam distribuídas assim: 54 no quartil 1;57 no quartil 2;53 no quartil 3 e57 no quartil 4.E, no final do $2^{\circ}$ ano (2013) a distribuição das escolas era a seguinte: 55 no quartil $1 ; 55$ no quartil $2 ; 55$ no quartil 3 e 56 no quartil 4.

\section{Tabela 28: Distribuição das escolas em quartis}

\begin{tabular}{ccccccc}
\hline & 2012 (entrada) & \multicolumn{2}{c}{2012 (saída) } & \multicolumn{2}{c}{2013} \\
\hline Quartis & $\begin{array}{c}\text { Número } \\
\text { de } \\
\text { escolas }\end{array}$ & Percentual & $\begin{array}{c}\text { Número } \\
\text { de } \\
\text { escolas }\end{array}$ & Percentual & $\begin{array}{c}\text { Número } \\
\text { de } \\
\text { escolas }\end{array}$ & Percentual \\
Quartil 1 & 55 & 24,9 & 54 & 24,4 & 55 & 24,9 \\
Quartil 2 & 54 & 24,4 & 57 & 25,8 & 55 & 24,9 \\
Quartil 3 & 57 & 25,8 & 53 & 24 & 55 & 24,9 \\
Quartil 4 & 55 & 24,9 & 57 & 25,8 & 56 & 25,3 \\
Total & 221 & 100 & 221 & 100 & 221 & 100 \\
\hline
\end{tabular}

Fonte: Elaboração própria a partir dos dados do PAEBES-Alfa

Após verificar a distribuição das escolas por quartis, o estudo analisou quais escolas mudaram de quartil entre uma avaliação e outra. O objetivo foi verificar se a média de desempenho das escolas teve uma variação expressiva que a permitiu mudar de quartil. As tabelas que seguem permitem observar a mudança de quartil. De acordo com a tabela 29: 1 escola caiu 3 quartis entre as duas avaliações; 10 escolas caíram 2 quartis entre as duas avaliações; 49 escolas caíram 1 quartil; 106 escolas se mantiveram no mesmo quartil; 40 escolas subiram 1 
quartil; 12 escolas subiram 2 quartis; 3 escolas subiram 3 quartis. Entre o fim de 2012 (final do $1^{\circ}$ ano) e o fim de 2013 (final do $2^{\circ}$ ano), os dados mostram que 7 escolas caíram 3 quartis; 13 escolas caíram 2 quartis; 40 escolas caíram 1 quartil; 96 escolas se mantiveram no mesmo quartil; 47 escolas subiram 1 quartil; 15 escolas subiram 2 quartis; e 3 escolas subiram 3 quartis.

Tabela 29: Escolas que mudaram de quartil

\begin{tabular}{|c|c|c|c|c|}
\hline & \multicolumn{2}{|c|}{ Entre as avaliações 1 e 2} & \multicolumn{2}{|c|}{ Entre as avaliações 2 e 3} \\
\hline Quartis & $\begin{array}{l}\text { Número de } \\
\text { escolas }\end{array}$ & Percentual & $\begin{array}{l}\text { Número de } \\
\text { escolas }\end{array}$ & Percentual \\
\hline-3 & 1 & 0,5 & 7 & 3,2 \\
\hline-2 & 10 & 4,5 & 13 & 5,9 \\
\hline-1 & 49 & 22,2 & 40 & 18,1 \\
\hline 0 & 106 & 48 & 96 & 43,4 \\
\hline 1 & 40 & 18,1 & 47 & 21,3 \\
\hline 2 & 12 & 5,4 & 15 & 6,8 \\
\hline 3 & 3 & 1,4 & 3 & 1,4 \\
\hline Total & 221 & 100 & 221 & 100 \\
\hline
\end{tabular}

Após analisar a distribuição das escolas nos quartis, o estudo realizou um procedimento estatístico denominado cluster que tem como finalidade agrupar as escolas segundo características semelhantes de forma a criar perfis.

Com base nas informações de número de turmas, rede, valor agregado e quartis nos dois períodos (inicio e fim do $1^{\circ}$ ano e fim do $1^{\circ}$ ano e fim do $2^{\circ}$ ano), foram criados 8 perfis de escolas. A tabela 30 apresenta o número de escolas em cada cluster e o quadro 11 apresenta as características das escolas de cada agrupamento.

Tabela 30: Distribuição das escolas nos 8 perfis

\begin{tabular}{cccc}
\hline Cluster & $\begin{array}{c}\text { Número de } \\
\text { escolas }\end{array}$ & Percentual & $\begin{array}{c}\text { Percentual } \\
\text { válido }\end{array}$ \\
\hline Cluster 1 & 26 & 11,8 & 11,8 \\
Cluster 2 & 21 & 9,5 & 21,3
\end{tabular}




\begin{tabular}{lccc} 
Cluster 3 & 4 & 1,8 & 23,1 \\
Cluster 4 & 27 & 12,2 & 35,3 \\
Cluster 5 & 58 & 26,2 & 61,5 \\
Cluster 6 & 49 & 22,2 & 83,7 \\
Cluster 7 & 24 & 10,9 & 94,6 \\
Cluster 8 & 12 & 5,4 & 100 \\
Total & 221 & 100 & \\
\multicolumn{4}{l}{ Fonte: Elaboração própria a partir dos dados do } \\
PAEBES-Alfa
\end{tabular}

\section{Quadro 11: Descrição das características das escolas nos clusters}

\begin{tabular}{|c|c|c|c|c|}
\hline Clusters & Rede & $\begin{array}{c}\text { Valor } \\
\text { agregado } \\
\text { (período 1) }\end{array}$ & $\begin{array}{c}\text { Valor } \\
\text { Agregado } \\
\text { (período 2) }\end{array}$ & Quartil \\
\hline Cluster 1 & Municipal & $\begin{array}{l}\text { Valor agregado } \\
\text { positivo }\end{array}$ & $\begin{array}{l}\text { Valor agregado } \\
\text { positivo }\end{array}$ & $\begin{array}{l}\text { Escolas que se situam no quartil } 1 \text { nas três } \\
\text { avaliações }\end{array}$ \\
\hline Cluster 2 & Municipal & $\begin{array}{l}\text { Valor agregado } \\
\text { positivo }\end{array}$ & $\begin{array}{l}\text { Valor agregado } \\
\text { positivo }\end{array}$ & $\begin{array}{l}\text { Escolas que se situam no quartil } 4 \text { nas três } \\
\text { avaliações }\end{array}$ \\
\hline Cluster 3 & $\begin{array}{c}\text { Municipal e } \\
\text { estadual }\end{array}$ & $\begin{array}{l}\text { Valor agregado } \\
\text { negativo }\end{array}$ & $\begin{array}{l}\text { Valor agregado } \\
\text { negativo }\end{array}$ & $\begin{array}{l}\text { Escolas que estão no quartil } 4 \text { nas } \\
\text { avaliações de entrada e saída de } 2012 \text { e } \\
\text { caem de quartil na avaliação de } 2013\end{array}$ \\
\hline Cluster 4 & Municipal & $\begin{array}{l}\text { Valor agregado } \\
\text { positivo }\end{array}$ & $\begin{array}{l}\text { Valor agregado } \\
\text { positivo }\end{array}$ & $\begin{array}{l}\text { Escolas que se situam no quartil } 4 \text { na } \\
\text { avaliação de entrada em } 2012 \text {. Algumas } \\
\text { escolas permanecem no quartil } 4 \text { nas } \\
\text { outras duas avaliações e algumas escolas } \\
\text { caem progressivamente de quartil ao } \\
\text { longo das outras duas avaliações }\end{array}$ \\
\hline Cluster 5 & Municipal & $\begin{array}{l}\text { Valor agregado } \\
\text { positivo }\end{array}$ & $\begin{array}{l}\text { Valor agregado } \\
\text { positivo }\end{array}$ & $\begin{array}{c}\text { Escolas que estão em diferentes quartis na } \\
\text { entrada de } 2012 \text { e que mudam de quartil } \\
\text { ao longo das outras duas avaliações, ou } \\
\text { para cima ou para baixo }\end{array}$ \\
\hline Cluster 6 & Municipal & $\begin{array}{l}\text { Valor agregado } \\
\text { positivo }\end{array}$ & $\begin{array}{l}\text { Valor agregado } \\
\text { positivo }\end{array}$ & $\begin{array}{c}\text { Escolas que se situam no quartil } 1 \text { ou } 2 \text { na } \\
\text { enrada de } 2012 \text { e que mudam de quartil } \\
\text { nas outras duas avaliações, sempre para } \\
\text { cima }\end{array}$ \\
\hline Cluster 7 & $\begin{array}{c}\text { Municipal e } \\
\text { estadual }\end{array}$ & $\begin{array}{l}\text { Valor agregado } \\
\text { positivo }\end{array}$ & $\begin{array}{l}\text { Valor agregado } \\
\text { positivo }\end{array}$ & $\begin{array}{c}\text { Escolas que se situam no quartil } 1 \text { na } \\
\text { primeira avaliação. Algumas escolas } \\
\text { permanecem no quartil } 1 \text { ao longo das } \\
\text { outras duas avaliações e algumas escolas } \\
\text { mudam de quartil para cima }\end{array}$ \\
\hline Cluster 8 & $\begin{array}{l}\text { Municipal, } \\
\text { estadual e } \\
\text { particular }\end{array}$ & $\begin{array}{l}\text { Valor agregado } \\
\text { positivo }\end{array}$ & $\begin{array}{l}\text { Valor agregado } \\
\text { negativo }\end{array}$ & $\begin{array}{l}\text { Escolas que se situam no quartil } 4 \text { nas três } \\
\text { avaliações }\end{array}$ \\
\hline
\end{tabular}

Fonte: Elaboração própria a partir dos dados do PAEBES-Alfa 
Com essas informações agregadas, fez-se um novo filtro com os seguintes critérios:

1) Escolas que permaneceram nas 3 avaliações nos quartis 1 e 4 (escolas que agregaram valor ou não agregaram valor, pois a variação da média de desempenho não permitiu que as escolas mudassem de quartis).

2) Escolas que aumentaram suas médias de desempenho e conseguiram mudar de quartil.

Temos assim dois tipos de escolas:

\section{Quadro 12: Os dois tipos de escolas}

\begin{tabular}{|l|c|l|c|}
\hline \multicolumn{1}{|c|}{$\begin{array}{c}\text { Tipo 1 - Escolas que subiram de } \\
\text { quartil. }\end{array}$} & \multicolumn{2}{c|}{ Tipo 2 - Escolas que cairam de } \\
quartil. \\
\hline \multicolumn{1}{|c|}{ Avaliação } & Quartil & \multicolumn{1}{c|}{ Avaliação } & Quartil \\
\hline \multicolumn{1}{|c|}{ Caso 1 } & & \multicolumn{1}{c|}{ Caso 1 } & \\
\hline $\begin{array}{l}\text { Avaliação 1 (inicio do 1o } \\
\text { ano - 2012) }\end{array}$ & 1 & $\begin{array}{l}\text { Avaliação 1 (inicio do } \\
\text { 1o ano - 2012) }\end{array}$ & 4 \\
\hline $\begin{array}{l}\text { Avaliação 2 (final do 1o } \\
\text { ano - 2012) }\end{array}$ & 2 & $\begin{array}{l}\text { Avaliação 2 (final do 1o } \\
\text { ano - 2012) }\end{array}$ & 2 \\
\hline $\begin{array}{l}\text { Avaliação 3 (final do 2o } \\
\text { ano - 2013) }\end{array}$ & 3 & $\begin{array}{l}\text { Avaliação 3 (final do 2o } \\
\text { ano - 2013) }\end{array}$ & 1 \\
\hline \multicolumn{1}{|c|}{ Caso 2 } & 2 & $\begin{array}{l}\text { Avaliação 1 (inicio do } \\
\text { 1o ano - 2012) }\end{array}$ & 4 \\
\hline $\begin{array}{l}\text { Avaliação 1 (inicio do 1o } \\
\text { ano - 2012) }\end{array}$ & 3 & $\begin{array}{l}\text { Avaliação 2 (final do 1o } \\
\text { ano - 2012) }\end{array}$ & 3 \\
\hline $\begin{array}{l}\text { Avaliação 2 (final do 1o } \\
\text { ano - 2012) }\end{array}$ & 4 & $\begin{array}{l}\text { Avaliação 3 (final do 2o } \\
\text { ano - 2013) }\end{array}$ & 2 \\
\hline $\begin{array}{l}\text { Avaliação 3 (final do 2o } \\
\text { ano - 2013) }\end{array}$ & & \\
\hline
\end{tabular}

Fonte: Elaboração própria a partir dos dados do PAEBES-Alfa

Respeitando-se esses critérios, 48 escolas foram selecionadas. Como o intuito é verificar as escolas públicas, optou-se por excluir as 6 escolas particulares restando, portanto, 42. A partir dessas informações, criaram-se quatro perfis de escolas, que estão apresentadas no quadro 13.

Quadro 13: Perfis das escolas

\begin{tabular}{|c|c|c|}
\hline Perfil & Valor agregado & Mudança de quartil \\
\hline Perfil 1 & Alto VA & Não \\
\hline Perfil 2 & Baixo ou nenhum VA & Não \\
\hline
\end{tabular}




\begin{tabular}{|l|c|c|}
\hline Perfil 3 & Alto VA & Sim \\
\hline Perfil 4 & Baixo ou nenhum VA & Sim $^{22}$ \\
\hline
\end{tabular}

Fonte: Elaboração própria a partir dos dados do PAEBES-Alfa

Para selecionar as 4 escolas um novo filtro foi definido: os municípios. As escolas deveriam estar localizadas ou no mesmo município ou em municípios geograficamente próximos para facilitar o trânsito e o acesso (quadro 14).

\section{Quadro 14: Número de escolas por município}

\begin{tabular}{|c|c|c|}
\hline Número de municípios & Município & Número de escolas \\
\hline 1 & Afonso Cláudio & 1 \\
\hline 2 & Aguia Branca & 1 \\
\hline 3 & Alfredo Chaves & 1 \\
\hline 4 & Aracruz & 1 \\
\hline 5 & Atílio Vivácqua & 1 \\
\hline 6 & Baixo Guandu & 1 \\
\hline 7 & Barra de São Francisco & 1 \\
\hline 8 & Cariacica & 3 \\
\hline 9 & Castelo & 2 \\
\hline 10 & Conceição da Barra & 1 \\
\hline 11 & Ibitirama & 1 \\
\hline 12 & Irupi & 1 \\
\hline 13 & Itarana & 1 \\
\hline 14 & Iuna & 1 \\
\hline 15 & Linhares & 2 \\
\hline 16 & Marataízes & 1 \\
\hline 17 & Muqui & 1 \\
\hline 18 & Pedro Canário & 1 \\
\hline 19 & Rio Bananal & 1 \\
\hline 20 & Rio Novo do Sul & 1 \\
\hline 21 & São Mateus & 1 \\
\hline 22 & Serra & 5 \\
\hline 23 & Viana & 5 \\
\hline 24 & Vila Pavão & 1 \\
\hline 25 & Vila Velha & 6 \\
\hline \multicolumn{2}{|c|}{ Total } & 42 \\
\hline
\end{tabular}

Fonte: Elaboração própria a partir dos dados do PAEBES-Alfa

\footnotetext{
${ }^{22}$ A mudança de quartil das escolas que agregaram pouco ou nenhum valor acontece por causa da baixa ou nenhuma variação da média de desempenho de um ano para o outro.
} 
Como mostra o quadro acima, apenas os municípios de Cariacica, Castelo, Linhares, Serra, Viana e Vila Velha possuíam mais de 1 escola após as filtragens descritas.

Optou-se por não escolher escolas do município de Castelo, pois todas elas estavam no perfil 2, e em Linhares, que apresentava duas escolas no perfil 1. Em Vila Velha, quatro escolas estavam no perfil 1 e duas estavam no perfil 3, e, em Viana, quatro escolas encontravam-se no perfil 2 e uma escola no perfil 1. O estudo optou por escolher quatro escolas que estivessem em municípios geograficamente próximos e que contemplassemos quatro perfis de escolas traçados. Optou-se então, pelas escolas de Cariacica, pois a escola Tulipa se enquadrou no perfil 3 - agrega muito valor e muda para cima de quartil ao longo das três avaliações, e a escola Rosa, que se enquadrou no perfil 4 - agrega pouco valor, mas muda para baixo de quartil ao longo das três avaliações. As escolas de Serra também foram selecionadas, pois este município é próximo ao de Cariacica e a escola Lírio se enquadrou no perfil 1 - agrega muito valor, mas encontra-se no quartil 1 nas três avaliações e a escola Girassol se enquadrou no perfil 2 - agrega pouco valor e está no quartil 4 nas três avaliações.

O valor agregado por essas escolas pode ser observado nos gráficos que seguem. A escola Tulipa (gráficos 10 e 11), obteve 398,36 de média em português (Leitura e Escrita) no início do $1^{\circ}$ ano. No final, sua média aumentou para 561,6, tendo, portanto, um valor agregado de 163,24 pontos. No fim do $2^{\circ}$ ano, sua média aumentou para 658,24 pontos, agregando mais 96,64 pontos de média de desempenho. Entre a onda 1 (entrada no $1^{\circ}$ ano em 2012) e a onda 3 (saída do $2^{\circ}$ ano em 2013), a escola agregou 259,88 pontos à média de desempenho. 


\section{Gráfico 10: Escola Tulipa - Evolução do desempenho médio em Português}

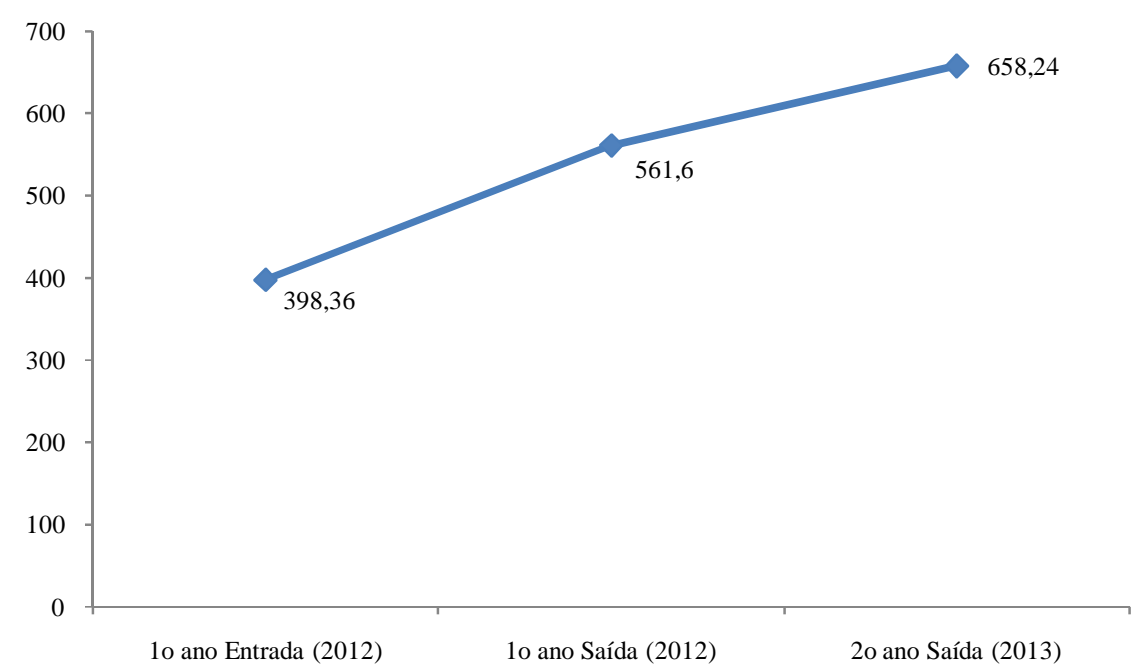

Fonte: Elaboração própria a partir dos dados do PAEBES-Alfa (2012 e 2013)

\section{Gráfico 11: Escola Tulipa - Valor agregado}

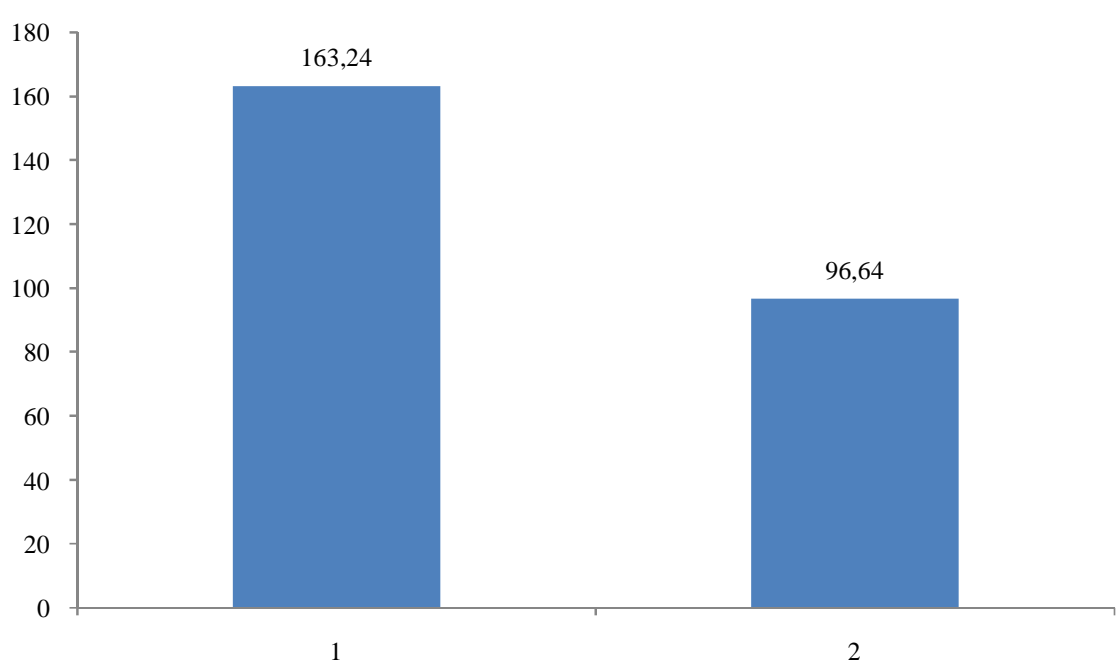

Fonte: Elaboração própria a partir dos dados do PAEBES-Alfa (2012 e 2013)

Embora a segunda escola investigada no município de Cariacica - escola Rosa (gráficos 12 e 13)- também tenha aumentado a média de desempenho dos seus estudantes, esse valor agregado ao aprendizado foi menor que o da escola Tulipa. 
No $1^{\circ}$ ano, a escola Rosa obteve, no início, a média de 481,9 pontos e, no final, 554,94. Ou seja, um aumento de 73,04 pontos - menos da metade do valor agregado pela escola Tulipa no mesmo período. No fim do $2^{\circ}$ ano, a escola obteve a média de 615,68 pontos, aumentando 60,74 pontos sua média de desempenho. No período analisado, a escola agregou 133,78 pontos à sua média.

\section{Gráfico 12: Escola Rosa - Evolução do desempenho médio em Português}

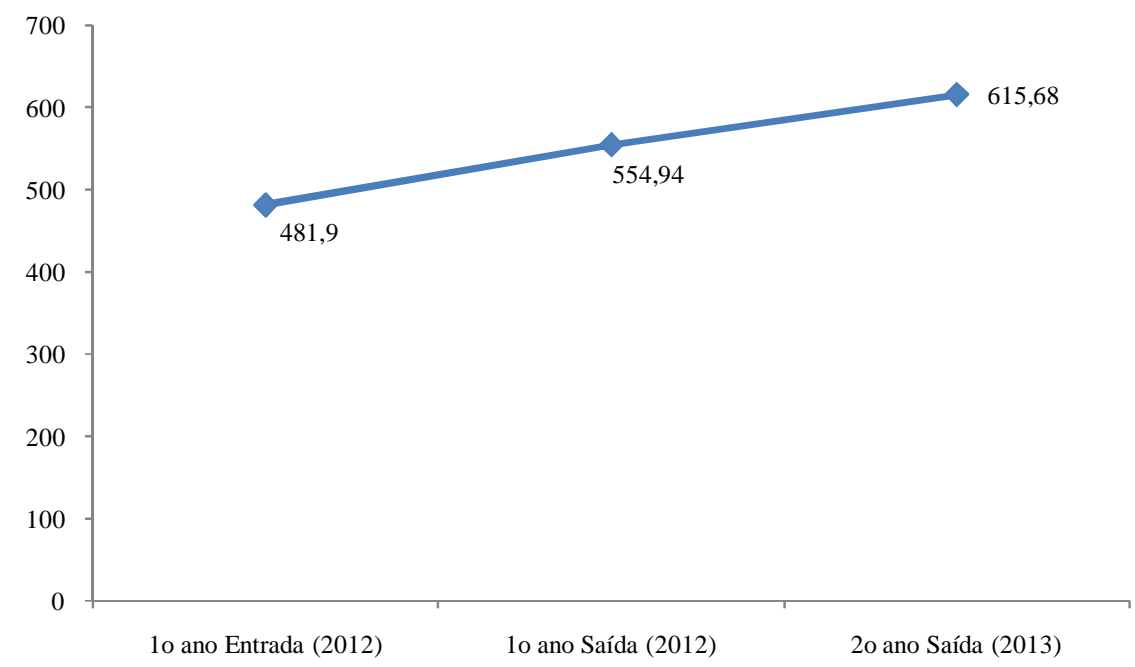

Fonte: Elaboração própria a partir dos dados do PAEBES-Alfa (2012 e 2013)

\section{Gráfico 13: Escola Rosa - Valor agregado}

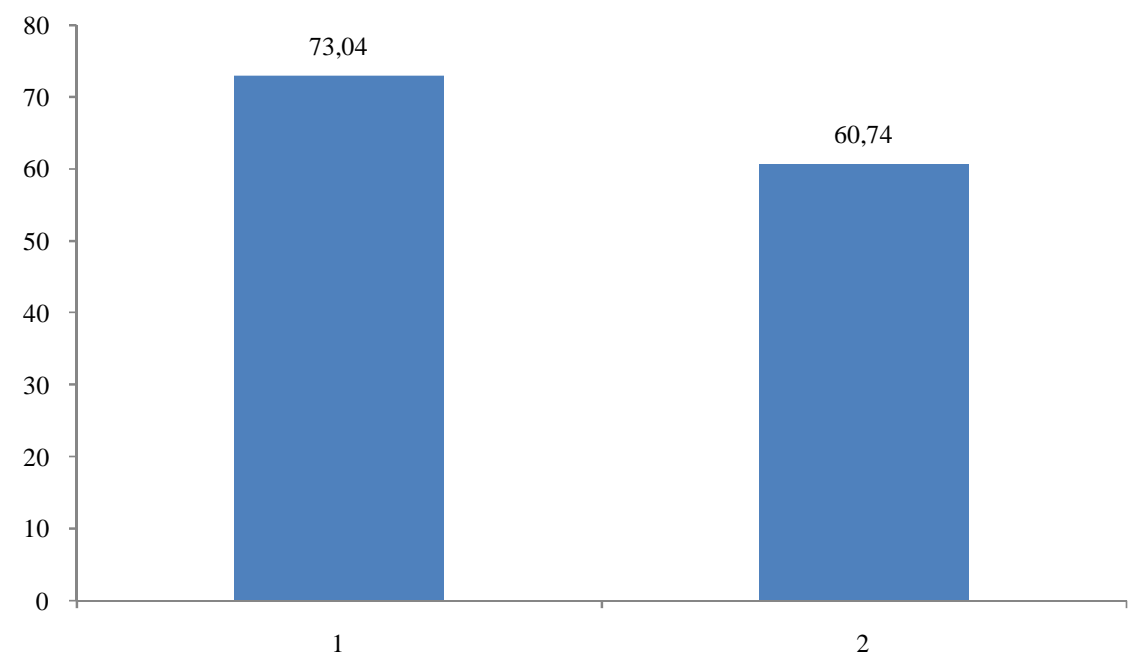

Fonte: Elaboração própria a partir dos dados do PAEBES-Alfa (2012 e 2013) 
Os dados mostram que, embora o ponto de partida da escola Tulipa (398,36 pontos na onda 1) seja inferior ao da escola Rosa (481,9 pontos na mesma onda), ela conseguiu fazer a média de desempenho dos seus alunos aumentar de forma significativa, obtendo no fim do $2^{\circ}$ ano, uma média superior à da escola Rosa.

Os próximos gráficos referem-se às escolas do município de Serra. A escola Lírio (gráficos 14 e 15)obteve no início do $1^{\circ}$ ano a média de 383,56 pontos. No final desse mesmo ano, a média aumentou para 508,33 pontos, ou seja, um aumento de 124,78 pontos de média. No final do $2^{\circ}$ ano, a média foi de 608,83 , o que corresponde ao aumento de 100,5 pontos na média.

\section{Gráfico 14: Escola Lírio - Evolução do desempenho médio em Português}

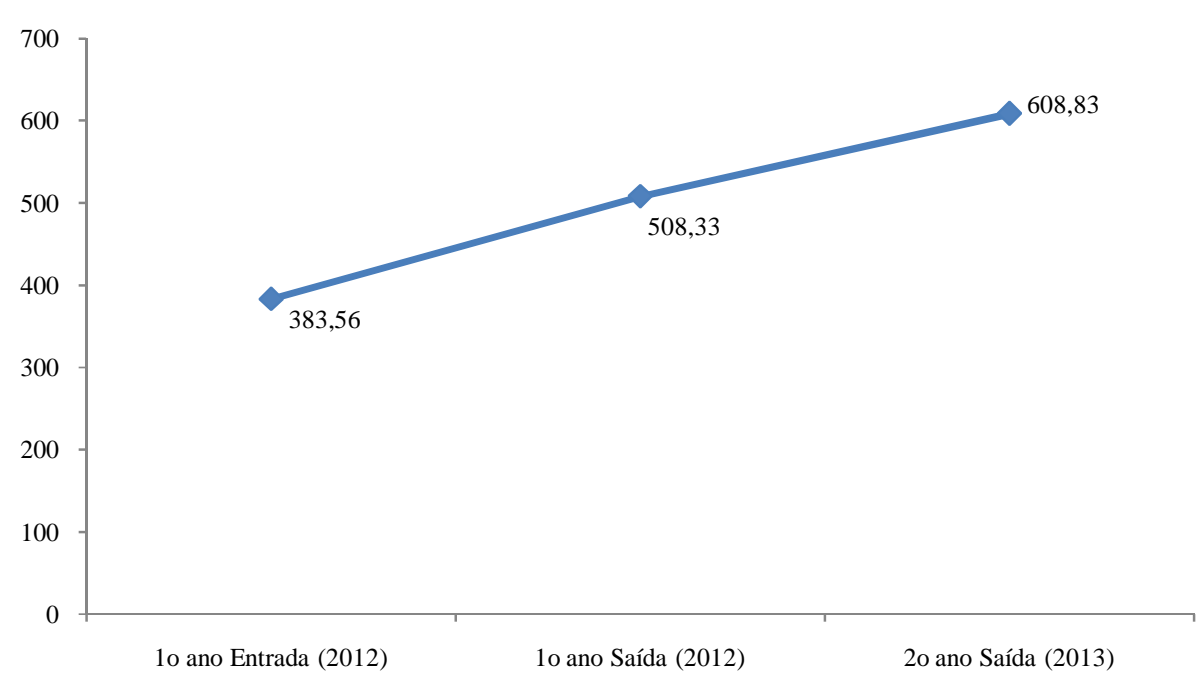

Fonte: Elaboração própria a partir dos dados do PAEBES-Alfa (2012 e 2013) 


\section{Gráfico 15: Escola Lírio - Valor agregado}

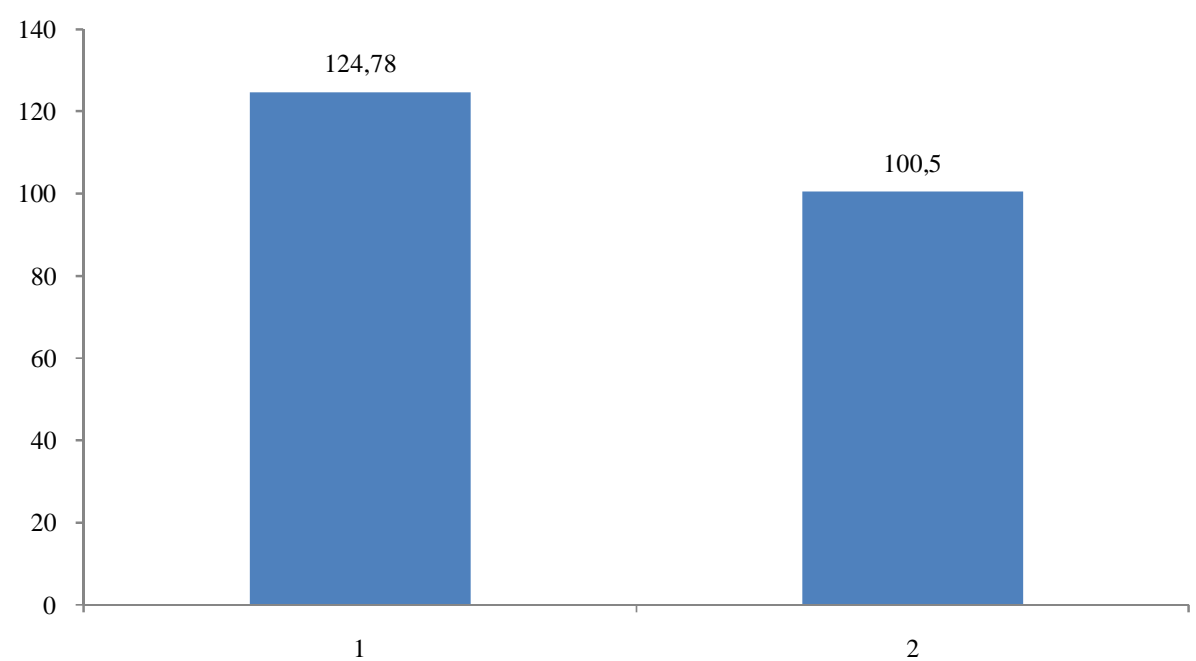

Fonte: Elaboração própria a partir dos dados do PAEBES-Alfa (2012 e 2013)

A escola Girassol (gráficos 16 e 17), por sua vez, teve no início do $1^{\circ}$ ano uma média muito superior à da escola Lírio: 542,66 pontos. No final desse mesmo ano, a escola alcançou a média de 636,76, agregando 94,1 pontos à média de desempenho dos alunos. No final do $2^{\circ}$ ano, essa média subiu para 683,84 , o que corresponde ao aumento de 47,08 pontos.

Gráfico 16: Escola Girassol - Evolução do desempenho médio em Português

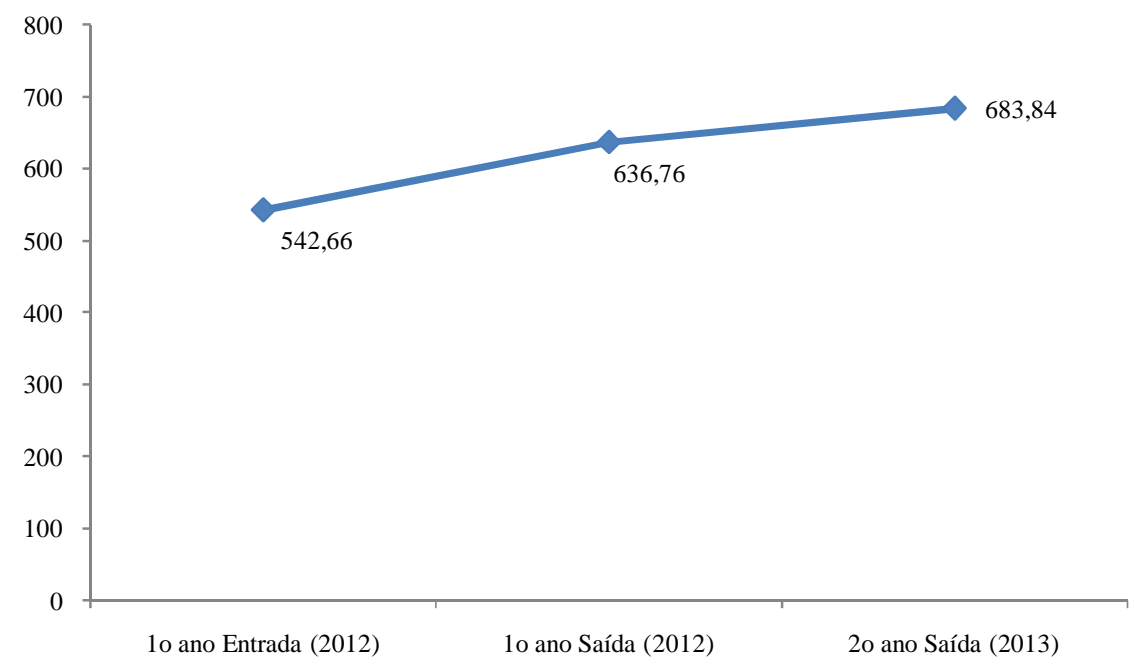

Fonte: Elaboração própria a partir dos dados do PAEBES-Alfa (2012 e 2013) 


\section{Gráfico 17: Escola Girassol -Valor agregado}

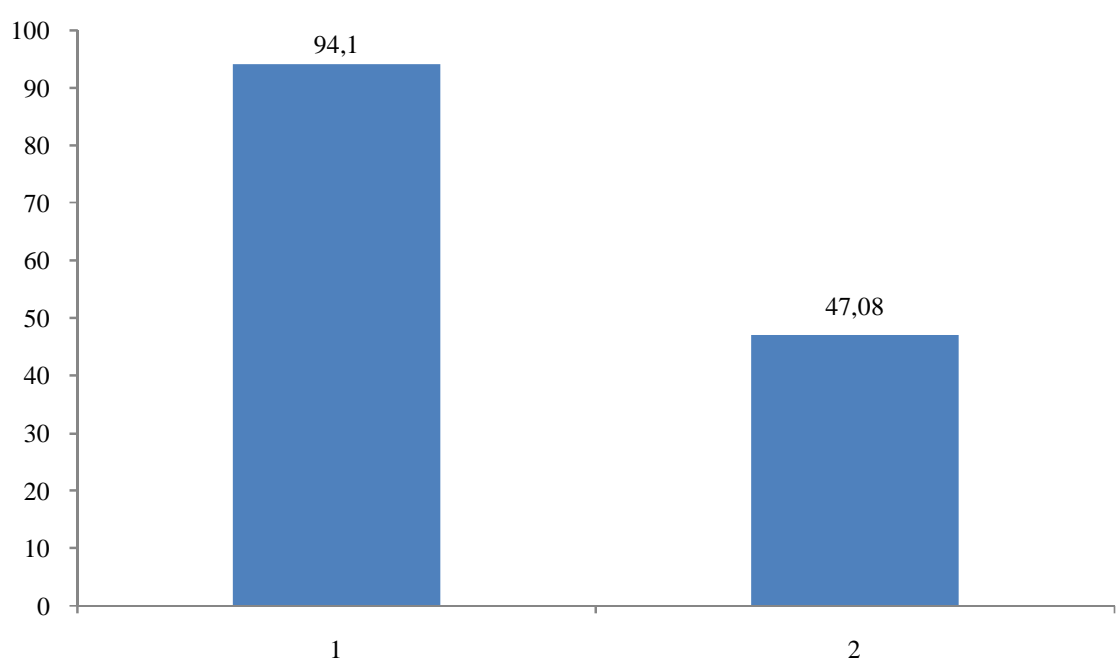

Fonte: Elaboração própria a partir dos dados do PAEBES-Alfa (2012 e 2013)

Observa-se que, embora a escola Lírio tenha conseguido agregar muito valor à média de desempenho dos alunos no PAEBES-Alfa, esse esforço não permitiu que a escola mudasse de quartil, ou melhor, de nível de desempenho. Isso pode ser explicado pelo baixíssimo resultado obtido no início do $1^{\circ}$ ano. Por outro lado, a escola Girassol alcançou, já no início do $1^{\circ}$ ano, um resultado muito bom, o que fez com que a média de desempenho aumentasse, mas não na mesma magnitude que na escola Lírio. Apesar disso, a escola Girassol encontra-se, desde a primeira avaliação, no quartil 1.

\subsection{A investigação quali-quanti}

A partir desta seleção, a pesquisa se voltou, na perspectiva micro, para a tentativa de abertura da "caixa preta" da escola. A primeira etapa foi a análise mais minuciosa dos dados quantitativos do PAEBES-Alfa e a segunda etapa foi dedicada à análise dos dados qualitativos.

Como dito anteriormente, a escolha das escolas foi feita com base nos dados de desempenho agregado de Leitura e Escrita. Entretanto, para a análise das desigualdades entre as escolas e entre as turmas, o estudo utilizou dados desagregados, observando a média e a variação do desempenho em Leitura e Escrita, separadamente, por escolas e por turmas. 
Complementarmente, fez-se uma investigação qualitativa, por meio de entrevistas e observações com a finalidade de abordar as desigualdades de oportunidades educacionais oferecida aos alunos (OLIVEIRA et al., 2013; CRAHAY, 2002, 2013; WALTENBERG, 2002), segundo os recursos escolares disponibilizados e as práticas didático-pedagógicas desenvolvidas nas escolas e suas turmas.

As principais características escolares observadas dizem respeito às ações pedagógicas apontadas por Crahay (2006); Oliveira et al. (2013), Waltenberg (2002) e, também, pela literatura em eficácia escolar (BROOKE, 2008; SLAVIN, 1996; SCHEERENS e BOSKER, 1997; SAMMONS, 2001; MURILLO, 2003)

São elas: 1) Professor que ensina para o conjunto da turma; apresenta as informações e atividades de modo claro e interessante; enfatiza a atividade do aluno; adapta o que ensina às diferentes necessidades e ritmos de aprendizagem dos alunos; tem altas expectativas em relação aos alunos; passa e corrige dever de casa; estimula a criatividade dos alunos e os desafia intelectualmente. O ensino estruturado e centrado nos alunos; aulas planejadas, com objetivos claros e comunicados aos alunos, e com conteúdos e habilidades organizadas em unidades sequenciadas; o envolvimento dos alunos em tarefas que requerem respostas criativas e em atividades que fomentem sua autonomia; monitoramento regular do progresso dos alunos, com realimentação imediata.Cobertura plena do currículo, com prioridade para os elementos centrais e básicos.Clima de sala de aula distendido, alegre, afetivo e respeitoso; altas expectativas e estímulo para que os alunos se envolvam nas atividades da aula. Tempo bem ocupado e adequado ao ritmo de aprendizagem dos alunos. Este fator considera o tempo alocado, isto é, disponibilizado pelo professor para a execução de tarefas e explicação de conteúdos e o tempo engajado, isto é, aquele no qual o aluno se envolve efetivamente com o ensino e a aprendizagem, Considera também a quantidade de tempo investida pelo aluno como produto da qualidade da instrução, de sua motivação e do tempo alocado pelo professor.

Assim nas salas de aula, foram observadas as práticas de professores relacionadas ao desenvolvimento das aulas, a atividades realizadas por professores e alunos, ao uso de materiais, aos comportamentos e à interação professor-aluno. Este último aspecto foi caracterizado nos planos afetivo-social e pedagógico- 
cognitivo, observando-se como o professor interpreta e sustenta a disciplina de sala de aula, o domínio que ele demonstra dos conteúdos e habilidades ensinadas, as estratégias que desenvolve para dar conta das diferenças entre os alunos e para motivá-los e avaliá-los, o uso que faz de recursos didáticos e de sanções e reforços positivos, e outras atividades pedagógicas de sala de aula relacionadas ao tempo efetivo de ensino.

Para conhecer estes aspectos, realizamos um trabalho de campo em cada uma das turmas das quatro escolas selecionadas. Neste trabalho fui acompanhada por colegas doutorandas com experiência no Ensino Fundamental, que, seguindo um roteiro estruturado (anexo 5),observamos, simultaneamente e de forma independente, os mesmos aspectos da sala de aula, visando àposterior triangulação de informações.

Cada uma das quatro escolas e suas turmas foi acompanhada, assim, por uma dupla de observadores que permaneceu em cada escola entre dois e três dias, conhecendo sua realidade social e pedagógica.

Para reunir informações sobre estes temas e sobre outros não previstos que pudessem emergir durante o trabalho de campo, as observadoras contaram, assim,com um roteiro de observação do trabalho em sala de aula ${ }^{23}$ que foi aplicado em todas as turmas que estavam cursando o $3^{\circ}$ ano escolar nas quatro escolas escolhidas.

Este roteiro dirigiu nosso olhar para o clima de aula,para o desenvolvimento das interações professor-aluno e para o aproveitamento do tempo com finalidade pedagógica. Trata-se de uma pauta composta por 96 itens organizados em quatro dimensões, a saber: i.) clima didático e gestão da turma; ii.) apoio ao desenvolvimento da autonomia do alunos; iii.) apoio ao desenvolvimento cognitivo e verbal dos alunos; iv.) apoio ao desenvolvimento afetivo-social do aluno.

Por exemplo, a dimensão i.) inclui indicadores tais como: "Mantém os alunos envolvidos com as tarefas propostas"; "Supervisiona e se mantém atento aos pedidos/necessidades de ajuda aos alunos"; "Intervém em situações de

\footnotetext{
${ }^{23}$ Este roteiro foi adaptado do instrumento originalmente elaborado e validado para o Chile por Seguel (1999). Ver a respeito "Escuelas efectivas em sectores de pobreza. ¿Quién dijo que no se puede? . Santiago de Chile : UNICEF, 2002.
} 
indisciplina ou conflito entre os alunos, sem fazer uso de "discursos" ou "castigos" exagerados".

Por sua vez, são exemplos de itens relativos ao professor na dimensão ii.): “ $\mathrm{O}$ (a) professor(a) valorizou as possíveis contribuições trazidas de casa pelos alunos para enriquecer os temas em estudo"; "Orientou a organização material dos alunos" e "Criou espaço na aula para que os alunos debatessem eventuais problemas e buscassem de forma compartilhada possíveis soluções para os mesmos".

Na dimensão iii.) abordamos o seguinte tipo de atividades dos professores: "Responde as perguntas ou solicitações dos alunos"; "Utiliza os erros das crianças como oportunidade de aprendizagem"; "Recoloca de forma correta as mensagens confusas, incompletas ou errôneas". Na dimensão iv.) temos itens sobre o professor do seguinte tipo: "Tem uma 'tonalidade afetiva' geralmente positiva"; "Favorece o respeito mútuo (não permite deboches/apelidos)"; "Se refere aos alunos por seus nomes próprios".

\subsubsection{Os dados de desempenho médio das escolas e das turmas}

A média do desempenho em Leitura e Escrita, na perspectiva longitudinal e entre as escola, é apresentada na tabela 31 e nos gráficos 18 e 19, nos quais podemos constatar que há uma alta variação do desempenho médio em Leitura entre as escolas no início do $1^{\circ}$ ano do Ensino Fundamental e que todas as escolas, com exceção da escola Rosa, melhoram progressivamente seus desempenhos. Ao final do $3^{\circ}$ ano, essa variação é relativamente baixa, indicando que, ao longo das quatro avaliações, o desempenho entre as escolas vai ficando mais homogêneo. Em outras palavras: no que diz respeito ao desempenho médio em Leitura, no início da escolarização, as escolas são mais heterogêneas, pois a variação do desempenho é grande, ao passo que, no final do ciclo de alfabetização, as escolas são mais homogêneas, pois a variação do desempenho entre elas é pequena.

Em Escrita, embora com menos intensidade, é possível observar a mesma situação: no início da alfabetização a variação da média do desempenho entre as escolas é maior que no fim, indicando que, ao longo dos três anos, as turmas se 
tornaram mais parecidas em seus resultados cognitivos. . Apesar disso, a variação das médias de Escrita é maior que a variação das médias em Leitura.

Pode-se constatar, portanto, que a desigualdade de conhecimento entre as escolas é maior no início da escolarização e que, ao longo da trajetória escolar, a aquisição do conhecimento se torna mais equitativa, na medida em que a variação das médias do desempenho diminui.

Tabela 31: Desempenho médio das escolas por avaliação

\begin{tabular}{ccccc|cccc}
\hline \multicolumn{1}{c}{ Leitura } & \multicolumn{5}{c}{ Escrita } \\
\hline & Av 1 & Av 2 & Av 3 & Av 4 & Av 1 & Av 2 & Av 3 & Av 4 \\
\hline Tulipa & 395,02 & 552,83 & 651,51 & 743,03 & 385,17 & 571,14 & 662,58 & 678,99 \\
Rosa & 612,47 & 693,91 & 662,15 & 682,1 & 353,15 & 514,94 & 607,4 & 646,74 \\
Girassol & 521,88 & 604,85 & 654,19 & 739,98 & 551,62 & 649,56 & 722,28 & 760,64 \\
Lírio & 400,3 & 499,92 & 610,25 & 699,82 & 407,67 & 590,5 & 687,18 & 728,4 \\
\hline Fonte: Elaboração própria a partir dos dados do PAEBES-Alfa
\end{tabular}

Gráfico 18: Evolução do desempenho médio em Leitura

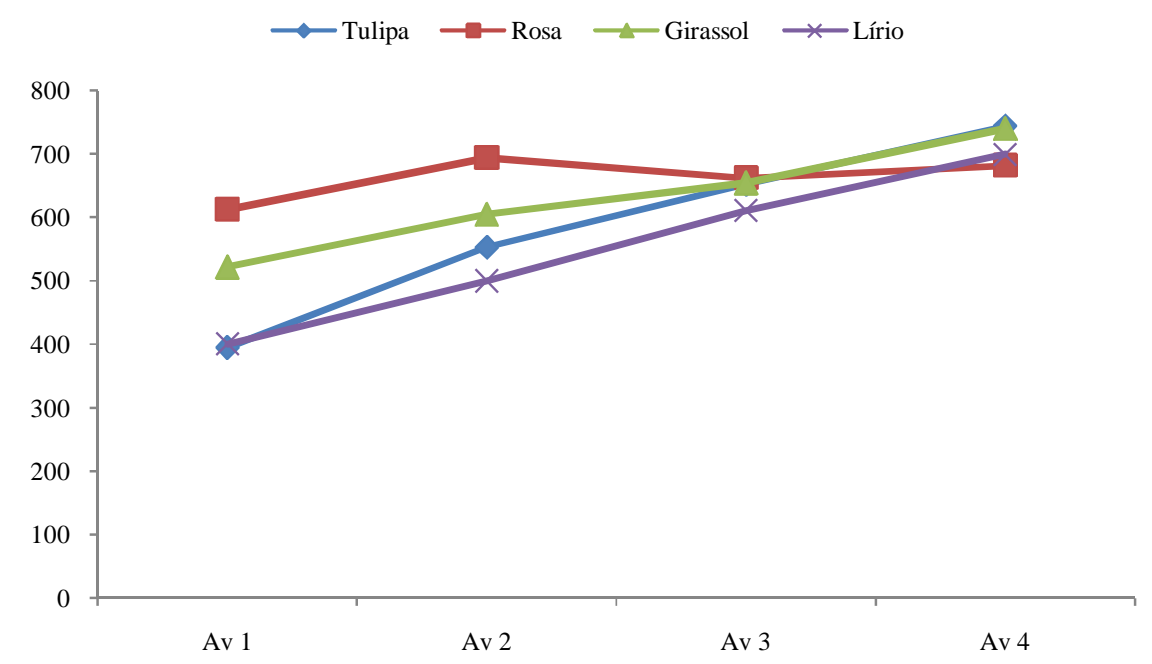

Fonte: Elaboração própria a partir dos dados do PAEBES-Alfa 


\section{Gráfico 19: Evolução de desempenho médio em Escrita}

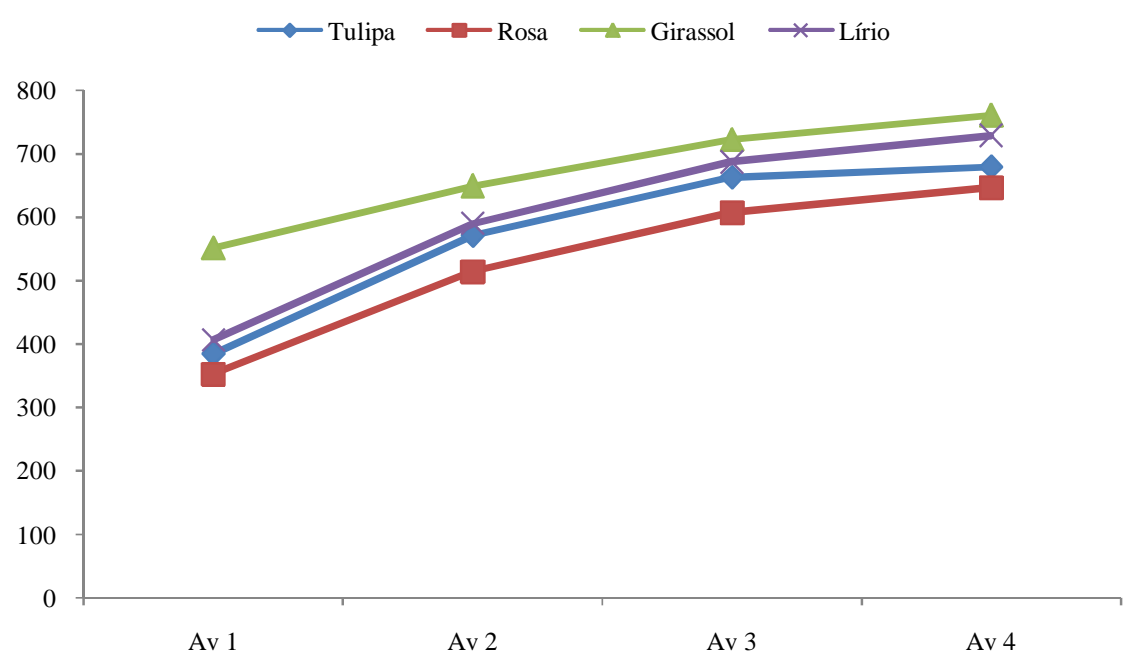

Fonte: Elaboração própria a partir dos dados do PAEBES-Alfa

Como pode ser visto nos gráficos 18 e 19, em Leitura, a variação do desempenho entre as escolas é bem maior no início da escolaridade. Isso pode ser claramente observado quando as médias são categorizadas em padrões de desempenho (anexo 2).

Segundo a escala de padrão de desempenho em Leitura do PAEBES-Alfa, no início do $1^{\circ}$ ano (avaliação 1), cada escola está situada num nível diferente, conforme é mostrado pela tabela 32. Já no final do $3^{\circ}$ ano (avaliação 4), as quatro escolas estão no nível proficiente, o que corrobora o processo de homogeneização ao longo do ciclo de alfabetização.

Por outro lado, em Escrita, as escolas possuem um padrão de desempenho diferenciado no início e no final do ciclo de alfabetização, evidenciando que, nessa faceta da alfabetização, há maior desigualdade pois a heterogeneidade de conhecimento entre as escolas é maior. 
Tabela 32: Padrões de desempenho das escolas

\begin{tabular}{|c|c|c|c|c|c|c|c|c|}
\hline & \multicolumn{4}{|c|}{ Leitura } & \multicolumn{4}{|c|}{ Escrita } \\
\hline & Av 1 & Av 2 & Av 3 & Av 4 & Av 1 & Av 2 & Av 3 & Av 4 \\
\hline $\begin{array}{l}\text { Tulip } \\
\text { a }\end{array}$ & $\begin{array}{l}\text { Abaixo } \\
\text { do } \\
\text { básico }\end{array}$ & $\begin{array}{c}\text { Proficie } \\
\text { nte }\end{array}$ & $\begin{array}{c}\text { Proficie } \\
\text { nte }\end{array}$ & $\begin{array}{c}\text { Proficie } \\
\text { nte }\end{array}$ & $\begin{array}{c}\text { Abaixo } \\
\text { do } \\
\text { básico }\end{array}$ & $\begin{array}{c}\text { Proficie } \\
\text { nte }\end{array}$ & $\begin{array}{c}\text { Proficie } \\
\text { nte }\end{array}$ & $\begin{array}{c}\text { Proficie } \\
\text { nte }\end{array}$ \\
\hline Rosa & $\begin{array}{c}\text { Avança } \\
\text { do }\end{array}$ & $\begin{array}{c}\text { Avança } \\
\text { do }\end{array}$ & $\begin{array}{c}\text { Proficie } \\
\text { nte }\end{array}$ & $\begin{array}{c}\text { Proficie } \\
\text { nte }\end{array}$ & $\begin{array}{c}\text { Abaixo } \\
\text { do } \\
\text { básico }\end{array}$ & $\begin{array}{c}\text { Proficie } \\
\text { nte }\end{array}$ & $\begin{array}{c}\text { Proficie } \\
\text { nte }\end{array}$ & Básico \\
\hline $\begin{array}{c}\text { Giras } \\
\text { sol }\end{array}$ & $\begin{array}{c}\text { Proficie } \\
\text { nte }\end{array}$ & $\begin{array}{c}\text { Avança } \\
\text { do }\end{array}$ & $\begin{array}{c}\text { Proficie } \\
\text { nte }\end{array}$ & $\begin{array}{c}\text { Proficie } \\
\text { nte }\end{array}$ & $\begin{array}{c}\text { Proficie } \\
\text { nte }\end{array}$ & $\begin{array}{c}\text { Avança } \\
\text { do }\end{array}$ & $\begin{array}{c}\text { Avança } \\
\text { do }\end{array}$ & $\begin{array}{c}\text { Avança } \\
\text { do }\end{array}$ \\
\hline Lírio & Básico & Básico & $\begin{array}{c}\text { Proficie } \\
\text { nte }\end{array}$ & $\begin{array}{c}\text { Proficie } \\
\text { nte }\end{array}$ & Básico & $\begin{array}{c}\text { Proficie } \\
\text { nte }\end{array}$ & $\begin{array}{c}\text { Proficie } \\
\text { nte }\end{array}$ & $\begin{array}{c}\text { Proficie } \\
\text { nte }\end{array}$ \\
\hline
\end{tabular}

Fonte: Elaboração própria a partir dos dados do PAEBES-Alfa

Além de observar a desigualdade de conhecimento entre as escolas, é possível verificar também a deisgualdade intra-escolar, por meio da comparação das médias de desempenho entre as turmas das escolas selecionadas. A ideia é averiguar se essas escolas foram capazes de garantir os conhecimentos de base a todos os estudantes até o fim do ciclo de alfabetização (CRAHAY, 2002).

Os gráficos a seguir apresentam a evolução do desempenho médio em Leitura e Escrita e do nível de desempenho por turma de cada escola (ver tabelas no anexo 4).

O gráfico 20 mostra que as quatro turmas ${ }^{24}$ da escola Tulipa obtiveram na primeira avaliação um desempenho médio em Leitura insatisfatório (abaixo do básico e básico). A análise mostra que as turmas B e C mantiveram um aumento progressivo das suas médias de desempenho, finalizando o ciclo de alfabetização com aprendizado satisfatório (proficiente na turma B e avançado na turma C). A turma $\mathrm{D}$, que teve um nível avançado no final do $1^{\circ}$ ano, apresenta uma queda expressiva de sua média de desempenho no final do $2^{\circ}$ ano, ficando no nível básico. Apesar disso, no $3^{\circ}$ ano, a média melhora bastante e a turma fica no nível avançado do padrão de desempenho definido pelo PAEBES-Alfa. Já a turma A, teve uma ligeira queda de desempenho no $3^{\circ}$ ano e finalizou o ciclo de alfabetização localizada no nível de desempenho abaixo do básico.

\footnotetext{
${ }^{24} \mathrm{~A}$ análise da evolução das turmas não se configura como longitudinal pois as turmas mudam de um ano para o outro. Ou seja, os agrupamentos estudantis se modificam durante o período em análise.
} 
Uma possível explicação para este resultado pode ser a distribuição dos professores nas turmas. Nas quatro turmas do $3^{\circ}$ ano, a professora da turma A é contratada, enquanto as outras três professoras são efetivas e sempre lecionaram, na escola, para as turmas do $3^{\circ}$ ano do Ensino Fundamental. A alocação dos docentes nas turmas é feita pela diretora, de acordo com o perfil de cada docente. $\mathrm{Na}$ entrevista realizada com a diretora, ela afirmou "não mexer" nas professoras das turmas $\mathrm{C}$ e $\mathrm{D}$, pois elas tem o perfil do $3^{\circ}$ ano. Além disso, todos os alunos do $3^{\circ}$ ano que apresentam alguma dificuldade de aprendizagem ou doença com laudo médico estão na turma A, incluindo um menino diagnosticado com esquizofrenia.

O que se observa, ainda no gráfico 20 , é que há uma variação significativa do desempenho entre o início e o fim do $1^{\circ}$ ano e que essa variação vai diminuindo ao longo do tempo. Com isso, no final do $3^{\circ}$ ano, as turmas B, C e D apresentam praticamente a mesma média, enquanto a turma A se distancia da média das outras três. Isso significa que as turmas B, C e D se tornaram mais homogêneas ao longo desse período.

Numa análise mais geral, ao final do ciclo de alfabetização, os alunos da turma A apresentam um prejuízo pedagógico no domínio da Leitura em comparação com as outras turmas, que se expressa na falta de aprendizagem ou na aprendizagem insatisfatória de certas habilidades, como, por exemplo, a habilidade de identificar o conflito gerador da narrativa, a dificuldade de reconhecer o locutor de um texto de curta extensão, ou para inferir o assunto do texto a partir do seu título Além disso, ainda não são plenamente capazes de reconhecer o humor num texto e o efeito de sentido produzido pelo uso de onomatopeias em poesias.

Estas habilidades, dentre outras, ainda não estão plenamente consolidadas pelos alunos da turma $\mathrm{A}$, ao passo que os alunos das demais turmas já são considerados alfabetizados, segundo a interpretação pedagógica da escala de proficiência do PAEBES-Alfa (anexo 2).

No que diz respeito à Escrita, o gráfico 21 mostra que a variação da média do desempenho na entrada e saída do $1^{\circ}$ ano é baixa, sendo que, entre essas duas avaliações, a turma $\mathrm{C}$ obteve o maior ganho. No $2^{\circ}$ ano, a variação das médias aumenta significativamente: a turma B alcança o nível avançado, as turmas A e C ficam no nível proficiente e a turma $\mathrm{D}$, que teve uma queda da média, fica no 
nível básico. No final do $3^{\circ}$ ano (avaliação 4), a variação do desempenho é um pouco maior que no início do $1^{\circ}$ ano, de forma que há uma homogeneização: as turmas D e B possuem médias de desempenho próximas e situam-se no nível proficiente e as turmas A e C, que também possuem médias próximas, situam-se no nível básico.

Neste domínio da alfabetização, isto é, na Escrita, as turmas A e C possuem uma defasagem de conhecimento em comparação com as turmas D e B, uma vez que pelo nível de desempenho que eles alcançaram, demostraram dominar habilidades ainda não plenamente consolidadas pelas turmas A e C. Por exemplo, as habilidades referentes à Escrita de palavras com dígrafos, marcas de nasalização e irregularidades ortográficos como o uso do "s"/"z"; "s"/"c"; "x"/“ch"; "g"/“j”; “ss"/“ç"; e também aos problemas de hipossegmentação (quando o aprendiz junta uma palavra na outra em uma frase ou texto), bem como à produção de textos de gêneros diferenciados com proposições comunicativas, como o bilhete e o convite, ainda não foram plenamente consolidados por esses estudantes, ao passo que seus colegas das turmas D e B já dominam tais habilidades.

\section{Gráfico 20: Evolução do desempenho médio em Leitura por turmas - Escola Tulipa}

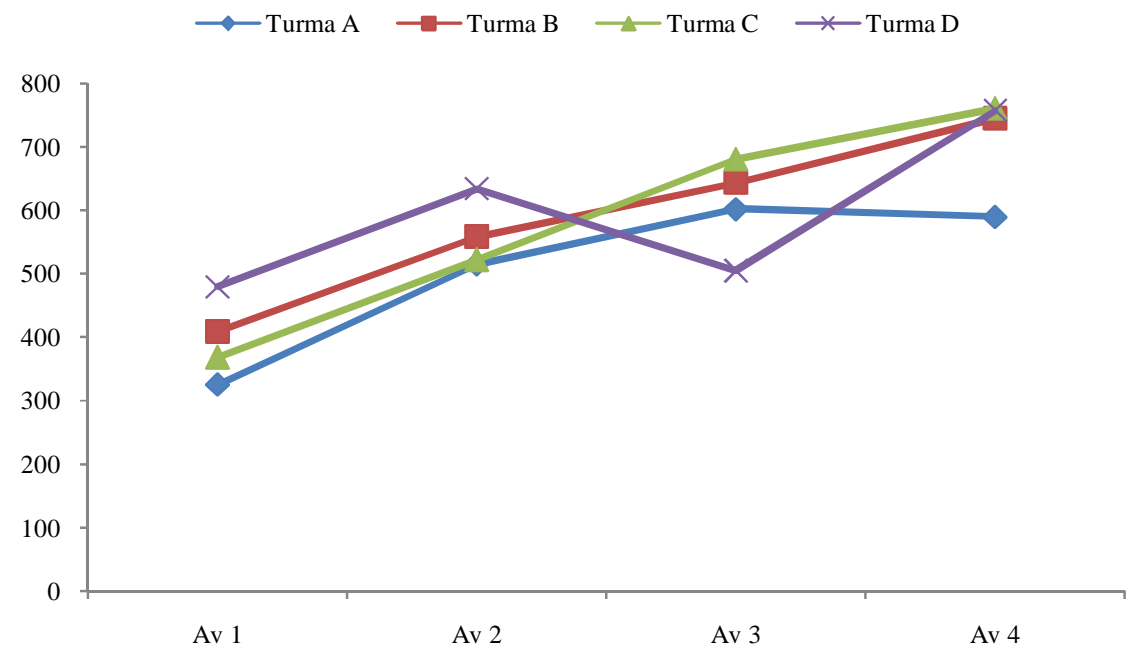

Fonte: Elaboração própria a partir dos dados do PAEBES-Alfa 


\section{Gráfico 21: Evolução do desempenho médio em Escrita por turmas -Escola Tulipa}

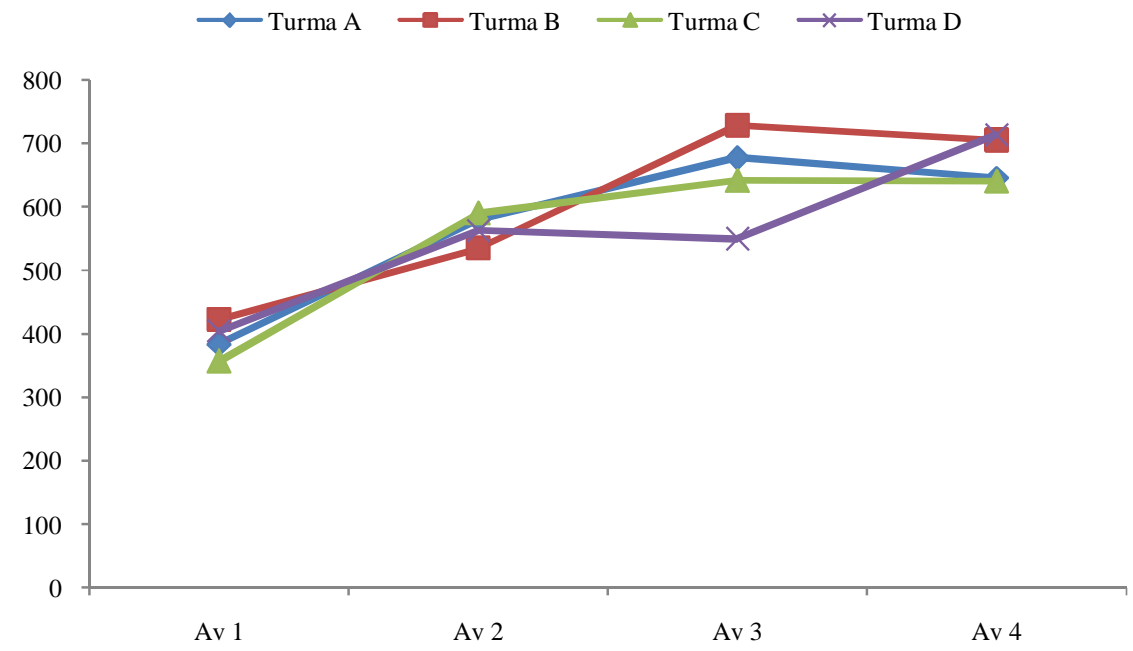

Fonte: Elaboração própria a partir dos dados do PAEBES-Alfa

No caso da escola Rosa, como pode ser observado nos gráficos 22 e 23, no início do $1^{\circ}$ ano, há uma variação significativa das médias de desempenho em Leitura e Escrita, sendo que a turma B possui a melhor média em ambos os domínios de conhecimento. Ao final do $3^{\circ}$ ano, a diferença entre a média das turmas diminui, e elas se tornam mais homogêneas. Essa diminuição da desigualdade entre turmas, no entanto, se deve em grande parte ao fato de a turma B apresentar queda significativa na média, em Leitura e Escrita.

Como pode ser visto, a turma B teve um ganho de proficiência nas três primeiras avaliações, sendo um ganho bem pequeno em Leitura e bastante expressivo em Escrita, sobretudo entre o $2^{\circ}$ e $3^{\circ}$ ano. Mas, no $3^{\circ}$ ano, essa turma mostra uma queda significativa de sua média de desempenho, principalmente em Leitura. As observações de sala de aula na turma B, mais especificamente a prática pedagógica do professor, podem contribuir para a compreensão dessa queda. Com efeito, durante a inserção no campo, observou-se que a professora passava atividades de Leitura e Escrita pouco desafiadoras para o $3^{\circ}$ ano escolar. No início de todas as semanas, a professora colava na parede, acima do quadro negro, folhas de papel com palavras e imagens relacionadas. Na aula observada, as palavras (Girafa - Macaco - Urso - Polvo - Jacaré - Pijama - Leão - Presente - Convite - Pinguim - Viviana) tinham sido retiradas pela professora do livro 
Viviana, a rainha do pijama que ela tinha lido momentos antes para os alunos, passando a embasar todas as atividades de Leitura e Escrita da semana. Durante a aula observada, que a professora anunciou ser de Língua Portuguesa, uma das atividades propostas solicitava que os alunos escrevessem em ordem crescente essas palavras. Um aluno perguntou o que significava "ordem crescente" e ela explicou que era "para escrever as palavras menores e depois as maiores". Para a realização dessa tarefa, então, os alunos deveriam contar o número de letras de cada palavra e escrevê-las em ordem crescente, tornando a tarefa mais sintonizada com os conteúdos de Matemática do que propriamente de Português. De fato, a tarefa proposta diz respeito à habilidade da primeira competência descrita da matriz de referência do PAEBES-Alfa: mobilização de ideias, conceitos e estruturas relacionadas à construção do significado dos números e suas representações, que inclui a habilidade comparar ou ordenar quantidades e números naturais.

São três, em síntese, os motivos que nos levam a considerar esta atividade inadequada: 1) a mesma não desenvolve habilidades de Língua Portuguesa, embora a professora tenha anunciado que a aula era dessa disciplina; 2) explora uma habilidade própria do $1^{\circ}$ ano do Ensino Fundamental; 3) não se articula com a história do livro lido pela professora momentos antes da proposta da atividade.

A professora afirmou utilizar em suas aulas o material didático-pedagógico disponibilizado no curso do PNAIC, pois a escola, segundo seu depoimento, não ofereceria esse tipo de material. Esse relato vai de encontro ao depoimento na entrevista da pedagoga, quem afirmou sempre disponibilizar os materiais que os professores solicitam e participar do planejamento das aulas de todos os professores.

No caso da turma A, a professora chegou à escola no mês de setembro para substituir a professora regente que tinha entrado de licença médica. Sua atuação na escola era provisória e pudemos observar que havia pouca interação dela com os demais colegas e com a equipe pedagógica. No entanto, segundo a fala dessa professora durante a entrevista, ao mesmo tempo em que a falta de interação não parecia ser um problema, e todas as suas solicitações eram atendidas pela equipe pedagógica. 
Durante as observações realizadas no mês de outubro, verificou-se que o corpo docente da escola estava cansado e que havia pouca interação entre a equipe pedagógica e os professores. Havia três profissionais (duas professoras e a coordenadora administrativa) de licença médica e, nas duas semanas de observações, a professora de artes e do projeto Mais Educação faltaram, o que evidenciou o despreparo da equipe em lidar com o absenteísmo docente, visto que as atividades propostas aos alunos eram improvisadas e inadequadas. Ilustra esta apreciação o fato de, na ausência da professora de artes, os alunos terem ficado sob a supervisão da profissional que cuidava da entrada da escola. Nessa ocasião, foi distribuída entre os alunos uma folha com a imagem de um cachorro, com a orientação de que o desenho deveria ser colorido. No entanto, não foi oferecido aos alunos nenhum material de pintura (tinta, lápis, pilot, canetinha etc.), e a maioria dos alunos não estava de posse desse tipo de material. O resultado foi que poucos alunos realizaram a tarefa e ficaram conversando e brincando, sob o olhar da profissional responsável pela entrada da escola.

$\mathrm{Na}$ entrevista realizada com a pedagoga dias depois da observação dessa aula, ela explicou que devido à ausência repentina da professora de artes, foi necessário improvisar a atividade, pois não havia um "plano B" para lidar com essa situação de absenteísmo. Explicou que a imagem do cachorro foi retirada da internet, impressa rapidamente na sala da coordenação e que, embora houvesse material para colorir, ele não foi disponibilizado porque estava trancado na sala da coordenação e a secretária administrativa, única pessoa a deter a chave do armário que guarda os materiais, não estava na escola naquele momento.

Trata-se de uma situação que revela a falta de planejamento pedagógico e de envolvimento da equipe pedagógica com os conteúdo e atividades trabalhados em sala de aula.

Observaram-se, também, problemas em relação ao clima escolar, uma vez que, na sala dos professores havia muito cochicho e reclamações sobre a Secretaria de Educação, as cobranças da equipe pedagógica, dos alunos, das famílias e de problemas pessoais.

De um modo geral, as turmas A e B finalizam o $3^{\circ}$ ano com níveis de desempenho desiguais nos dois domínios da alfabetização. Em Leitura, a turma A apresentou nível proficiente de desempenho e a turma B nível básico. Em termos 
cognitivos, isso significa que os estudantes da turma B não dominam habilidades como:

$\checkmark$ Contar sílabas em palavras formadas por diferentes padrões silábicos (consciência fonológica);

$\checkmark$ Identificar sílabas no padrão canônico (consoante/vogal) no final da palavra;

$\checkmark$ Realizar inferências a partir da Leitura de textos que conjugam linguagem verbal e não verbal, como histórias em quadrinhos e tirinhas.

$\checkmark$ Identificar gêneros textuais menos familiares, como a carta, e a finalidade ou assunto de textos de gêneros familiares, como bilhete, lista de compras, folheto, tabela de preços.

$\checkmark$ Localizar informações em textos de diversos gêneros, inclusive gráficos e tabelas, podendo tal informação estar no início, meio ou fim do texto.

No que diz respeito à Escrita, as duas turmas tiveram médias de desempenho próximas, embora estejam situadas em nível diferentes: a turma B finalizou o $3^{\circ}$ ano no nível proficiente, e a turma $\mathrm{B}$ no nível básico, o que implica dizer que os estudantes dessa turma ainda não consolidaram habilidades como:

$\checkmark$ Escritade palavras com dígrafos, marcas de nasalização e irregularidades ortográficas como o uso de "s"/"z"; "s"/"c"; "x"/“ch"; "g"/“j”;; "ss"/“ç";

$\checkmark$ Superação da hipossegmentação (quando o aprendiz junta uma palavra na outra)

$\checkmark$ Produção de textos de gêneros diferenciados com proposições comunicativas, como o bilhete e o convite 
Gráfico 22: : Evolução do desempenho médio em Leitura por turma - Escola Rosa

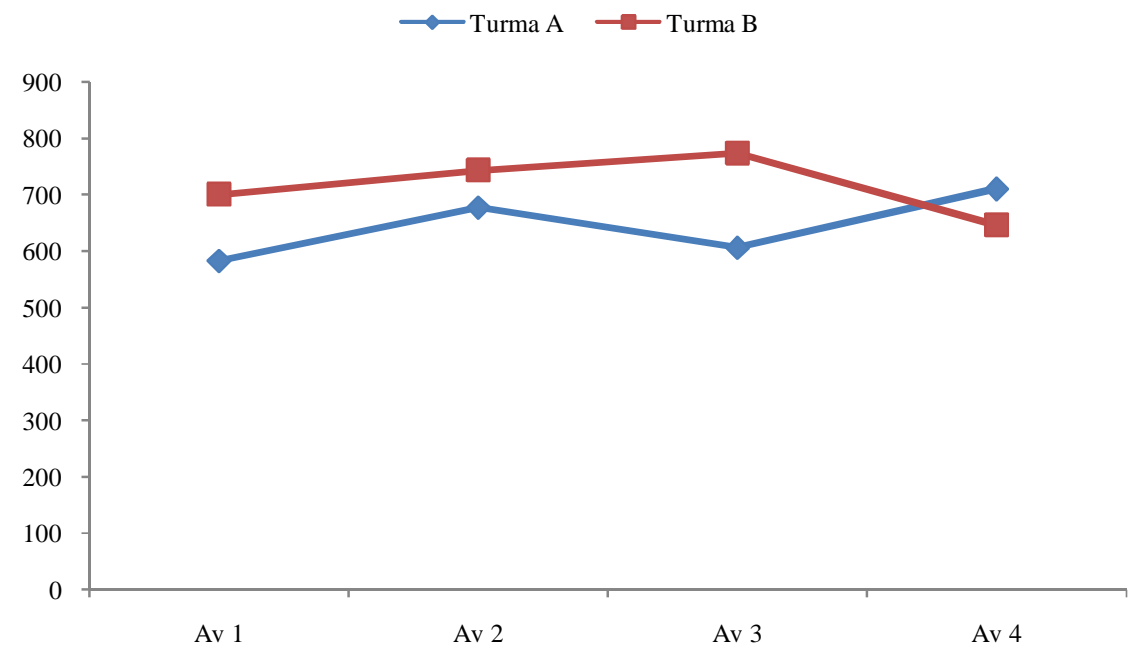

Fonte: Elaboração própria a partir dos dados do PAEBES-Alfa

\section{Gráfico 23: : Evolução do desempenho médio em Escrita por turma - Escola Rosa}

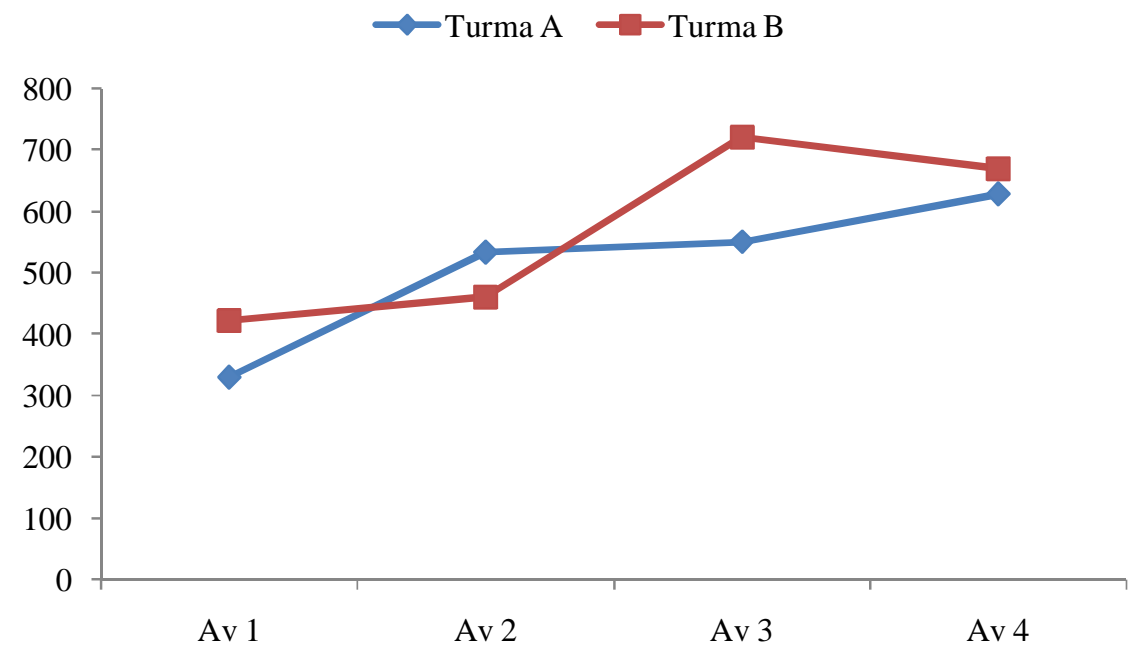

Fonte: Elaboração própria a partir dos dados do PAEBES-Alfa

Nas turmas da escola Girassol, por sua vez, o desempenho em Leitura e Escrita é mais heterogêneo no início do $1^{\circ}$ ano e ao longo do tempo a variação das médias vai diminuindo de forma que, no final do $3^{\circ}$ ano, essaa variação é pequena, como pode ser observado no gráfico 24 . Ou seja, ao longo dos primeiros anos de 
escolarização, as turmas vão se homogeneizando, chegando ao final do ciclo de alfabetização com desempenhos bastante similares. Além disso, desde o final do $1^{\circ}$ ano, as quatro turmas possuem níveis de aprendizagem satisfatórios nos dois domínios de conhecimento.

Nessa escola, todas as professoras do $3^{\circ}$ ano eram contratadas, sendo que a turma IV teve, ao longo do ano letivo, quatro professoras diferentes. A pedagoga explicou os motivos da alta rotatividade e ressaltou que isso afeta muito o desempenho dos alunos. Entretanto, de acordo com os dados do PAEBES-Alfa, a turma IV teve boas médias, alcançando um nível avançado de desempenho, tanto em Leitura quanto em Escrita (gráficos 24 e 25).

Nessas duas dimensões da alfabetização, aliás, as quatro atingiram níveis adequados de desempenho. Em Leitura, as turmas I e II situam-se no nível proficiente e as turmas III e IV no nível avançado. Em Escrita, as turmas I, III e IV situam-se no nível avançado e a turma II no nível proficiente.

Apesar de ambos os níveis de desempenho serem considerados adequados de acordo com a escala de proficiência do PAEBES-Alfa, a desigualdade de conhecimentos se evidencia quando da comparação das habilidades adquiridas entre as turmas. Isso porque as turmas com nível proficiente ainda não dominaram determinadas habilidades já consolidadas pelas turmas do nível avançado. Em Leitura algumas dessas habilidades são especificamente, as seguintes:

Ampliação da competência leitora no que se refere à identificação de elementos da narrativa e à realização de inferências do sentido de palavras e expressões.

$\checkmark$ Ampliação da familiaridade com gêneros textuais diversos.

$\checkmark$ Ampliação da capacidade de inferir informações em textos que conjugam linguagem verbal e não verbal, como tirinhas.

$\checkmark$ Identificação da relação entre pronomes anafóricos e seus referentes.

$\checkmark$ Ampliação da capacidade de identificar o efeito de sentido decorrente do uso de sinais de pontuação. Nesse intervalo, o estudante consegue identificar o interlocutor em textos como propagandas. 
Estabelecimento de relações lógico- discursivas entre partes ou elementos dos textos, como relações de causa e consequência e relações lógico-discursivas marcadas por conjunção temporal ou advérbio de tempo.

Em Escrita algumas das habilidades que ainda não estão plenamente consolidadas pelos alunos da turma II referem-se à

$\checkmark$ Produção de histórias a partir de uma cena ou sequência de cenas com todos os principais elementos que compõem uma narrativa: personagens praticando ações em uma sequência temporal; uso de articuladores, como marcadores temporais ("então", "depois");

$\checkmark$ Uso de recursos coesivos, como pronomes, que contribuem para a continuidade temática do texto sem torná-lo repetitivo.

\section{Gráfico 24: Evolução do desempenho médio em Leitura por turma - Escola Girassol}

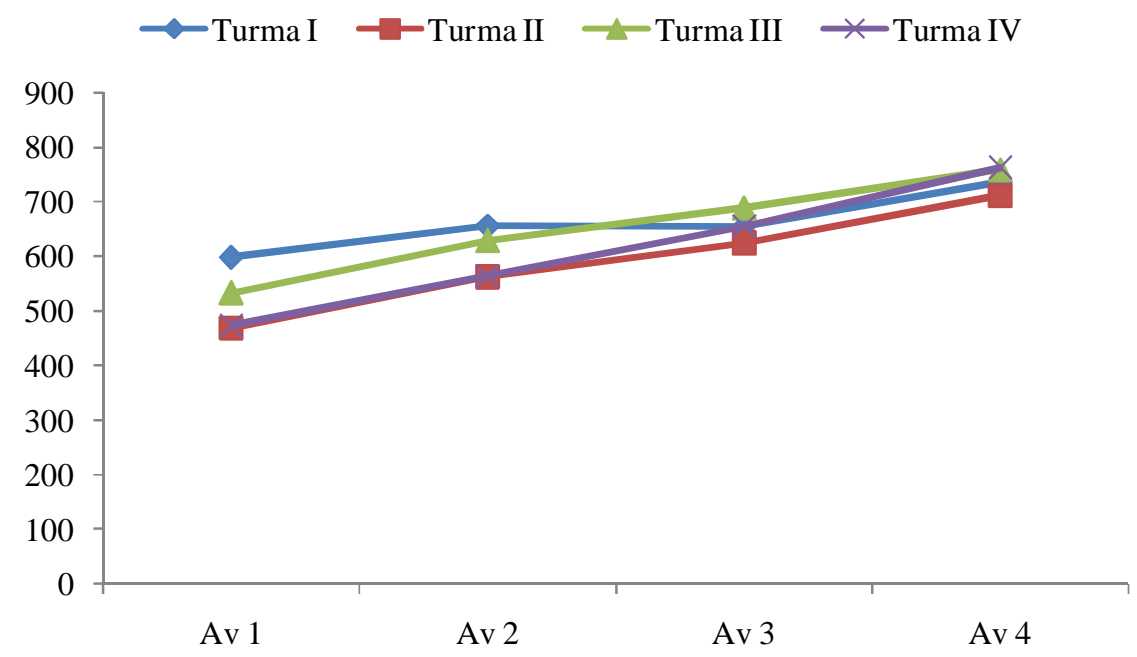

Fonte: Elaboração própria a partir dos dados do PAEBES-Alfa 


\section{Gráfico 25: Evolução do desempenho médio em Escrita por turma -Escola Girassol}

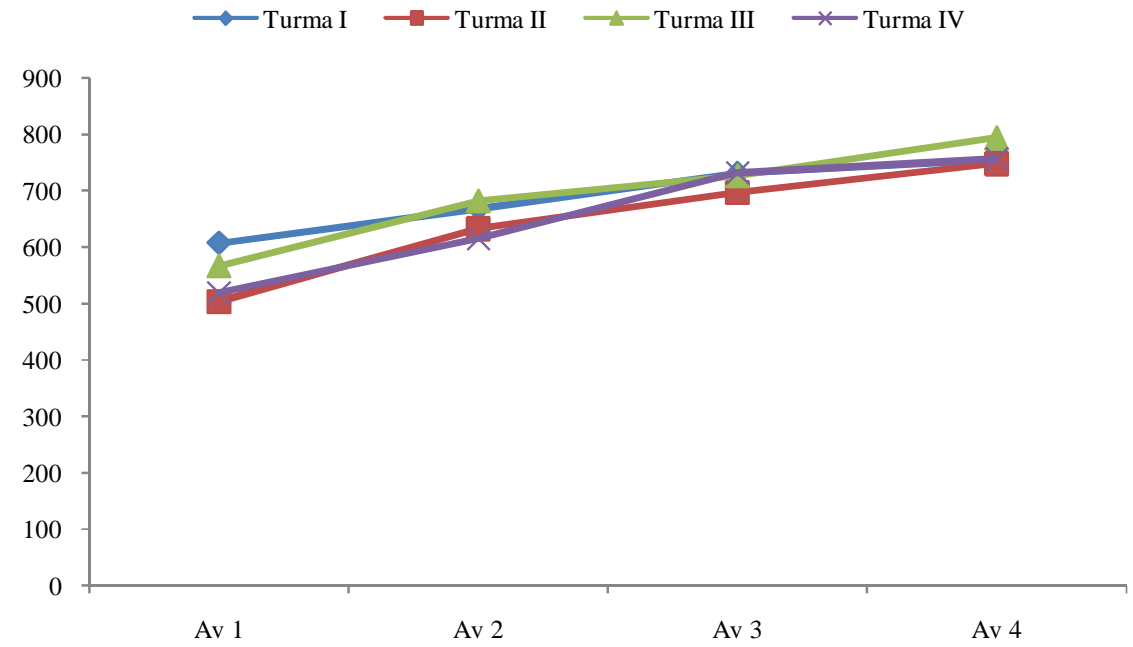

Fonte: Elaboração própria a partir dos dados do PAEBES-Alfa

Dentre as quatro escolas observadas, a escola Lírio foi a que obteve a menor variação inicial do desempenho em Leitura e Escrita (gráficos 26 e 27). Apesar de serem turmas mais homogêneas já no início do Ensino Fundamental, todas elas apresentam níveis de desempenho insatisfatórios (abaixo do básico e básico). Esses desempenhos foram melhorando progressivamente em todas as turmas ao longo dos três anos. E, no final do $3^{\circ}$ ano, todas as turmas alcançaram nível proficiente em Leitura e Escrita. Essa foi a escola que apresentou maior homogeneidade entre as turmas desde o início do ciclo de alfabetização e que teve melhoras constantes e progressivas em suas médias de desempenho de Leitura e Escrita.

Trata-se de uma escola localizada num bairro com alto índice de criminalidade e vulnerabilidade social. A grande maioria dos alunos mora no bairro. Segundo relato das pedagogas e da diretora, alguns alunos são filhos de traficantes, são "aviãozinhos", e há casos de alunos que abandonaram a escola para entrar no mundo do tráfico. A diretora relatou o caso de um aluno que precisou abandonar a escola porque a família teve de fugir, pois estava sendo ameaçada de morte por não pagar dívidas contraídas com o tráfico. Também relatou o caso de uma menina que abandonou a escola e, tempos depois, a diretora 
a viu vendendo bala/chiclete na rua. Essa menina era adotada e a mãe queria devolvê-la ao orfanato, pois ela seria uma criança "muito difícil”.

Além dessa caracterização social, as pedagogas e a diretora afirmaram que praticamente todos os alunos que entraram no $1^{\circ}$ ano frequentaram o Centro Municipal de Educação Infantil (CMEI) do bairro e, por isso, já são conhecidos de alguns professores que, no contra turno, atuam nesse centro.

Essas duas razões podem ajudar a compreender a homogeneidade das médias de desempenho das turmas logo no início do Ensino Fundamental. Grande parte dos alunos mora no mesmo bairro e, portanto, vive em um mesmo contexto socioeconômico. Além disso, a maioria frequenta a escola de educação infantil do bairro que possui muitos profissionais atuando, em turnos diferentes, nas duas instituições, o que faz com que os professores já conheçam os alunos que chegam à escola Lírio.

Como já mencionado, todas as quatro turmas possuem o nível proficiente em Leitura e Escrita, o que significa que as habilidades foram adquiridas de forma homogênea. Algumas das habilidades consolidas por esses alunos são:

Em Leitura:

$\checkmark$ Habilidades mais sofisticadas ligadas à consciência fonológica (contação de sílabas de palavras com diferentes padrões silábicos e o reconhecimento de diferenças sonoras entre palavras que se diferenciam por apenas um fonema);

$\checkmark$ Identificação do conflito gerador em narrativas, e o reconhecimentodo locutor de um texto de curta extensão;

$\checkmark$ Identificação, num texto, a quem pertence a fala de uma personagem.

$\checkmark$ Realização de inferência do assunto de um texto a partir do seu título, a percepção do efeito de humor num texto e o reconhecimento do efeito de sentido produzido pelo uso de onomatopeias em poesias.

$\checkmark$ Inferências de informações em textos que conjugam linguagem verbal e não verbal, como tirinhas. 
Identificação da relação entre pronomes anafóricos e seus referentes.

Em Escrita:

$\checkmark$ Escrita correta de palavras com algumas regras ortográficas: uso de "l" ou "u" em final de palavra; uso de "ss", “ç" ou "c", dentre outras;

$\checkmark$ Escrita de palavras com dígrafos, marcas de nasalização e irregularidades ortográficas como o uso de "s"/“z"; "s"/"c"; "x"/“ch"; "g”/“j”; "sss"/“ç".

$\checkmark$ Não ocorrência da hipossegmentação em ditados.

$\checkmark$ Produção de textos de gêneros mais familiares a partir da proposição de uma situação comunicativa: bilhete e convite.

\section{Gráfico 26: Evolução do desempenho médio em Leitura por turma - Escola Lírio}

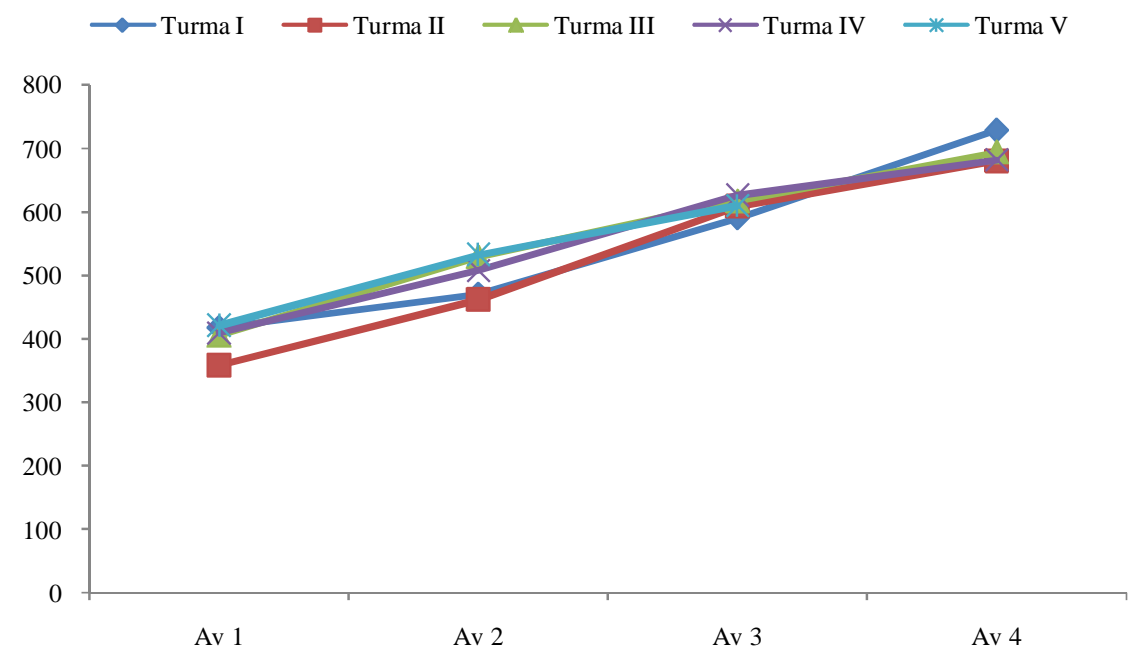

Fonte: Elaboração própria a partir dos dados do PAEBES-Alfa 


\section{Gráfico 27: Evolução do desempenho médio em Escrita por turma - Escola Lírio}

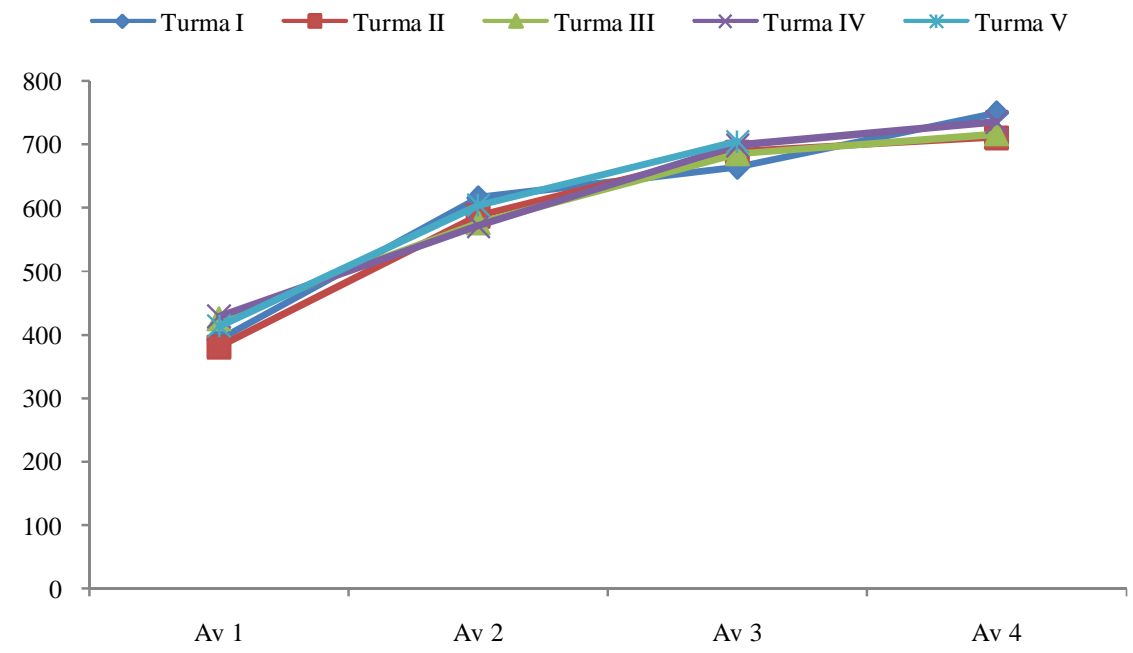

Fonte: Elaboração própria a partir dos dados do PAEBES-Alfa

Com base nos resultados obtidos, a hipótese de que as desigualdades entre as turmas é maior que entre as escolas é parcialmente confirmada. Os dados da tabela 32 mostram que, ao longo dos três anos, há variações no nível de desempenho, o que revela a desigualdade dos resultados escolares entre essas escolas. Por sua vez, quando se analisam os resultados das turmas ${ }^{25}$, nas escolas Tulipa e Rosa (localizadas em Cariacica), verifica-se que há desigualdades de desempenho, com turmas que iniciaram e finalizaram o ciclo de alfabetização com nível de desempenho insatisfatório (abaixo do básico/básico) e turmas com nível adequado (proficiente/avançado).

Em contrapartida, nas escolas Girassol e Lírio (localizadas em Serra), os resultados são mais igualitários, na medida em que a variação dos desempenhos é pequena. Na escola Lírio, por exemplo, todas as quatro turmas finalizaram o ciclo de alfabetização com no mesmo nível de desempenho proficiente em Leitura e Escrita na avaliação do $3^{\circ}$ ano.

${ }^{25}$ Tabelas no anexo 4 


\subsubsection{As características escolares}

Por meio das observações e das entrevistas, coletaram-se dados referentes a algumas características das escolas, apontadas pela literatura como fatores que contribuem para o bom desempenho dos estudantes (CRAHAY, 2002; BROOKE e SOARES, 2008; SOARES, 2008; OLIVEIRA et all., 2013; SLAVIN, 1996; SCHEERENS e BOSKER, 1997; SAMMONS, 2001; MURILLO, 2003).

Baseando-se nesse aporte teórico, o estudo foi a campo investigar qualitativamente algumas das categorias de análise enunciadas pela literatura em eficácia escolar, a saber: realização do dever de casa; cumprimento do currículo; 3) responsabilidade pelo aprendizado dos alunos; 4) não absenteísmo docente; 5) colaboração docente; 6) organização das turmas; 7) qualidade docente (formação e distribuição); 8) uso do tempo; 9) participação e envolvimento dos pais nas atividades escolares dos filhos.

\section{DEVER DE CASA}

Um dos aspectos relacionados à eficácia da escola diz respeito à atividade de passar e corrigir tarefas escolares realizadas pelos alunos em casa. Alguns estudos evidenciam o impacto positivo dessa prática pedagógica sobre o aprendizado dos estudantes (SOARES, 2002; MACHADO SOARES, 2003; PEDROSA, 2007, ALVES e FRANCO, 2008) e reforçam sua importância no processo de ensino-aprendizagem.

Das quatro turmas da escola Tulipa, a prática de verificar/corrigir o dever de casa foi observada em apenas duas salas de aula. Nas demais turmas, não houve correção do dever de casa. Foi interessante observar que, na turma em que a professora passa e corrige o dever, há uma aluna que nunca leva as tarefas para fazer em casa. Durante a entrevista, a professora revelou que essa aluna vive em um contexto social de alta vulnerabilidade. A mãe abandonou essa criança e os três irmãos mais novos por causa das drogas, sendo eles criados pela avó que rasga todas as folhas dos cadernos e livros dos netos para fazer fumo. Por isso, todo o material escolar dela e dos irmãos ficam na escola, que têm nessa instituição a única oportunidade de aprendizado sistemático. A professora também relatou que toda sexta-feira há, no mercado central da cidade a venda de produtos 
agrícolas para as grandes redes de supermercado, e que, nesses dias, a aluna e os irmãos faltam à escola para ir ao mercado central apanhar a sobra dos produtos que não foram vendidos para se alimentarem durante a semana. Essa aluna já reprovou duas vezes: tem 10 anos e, em 2014, estava no $3^{\circ}$ ano do Ensino Fundamental. A professora afirmou que agora essa aluna já está alfabetizada e que em 2015 cursaria o $4^{\circ}$ ano.

Nas entrevistas, a maioria das professoras afirmou passar dever de casa com frequência. Apenas as professoras da escola Rosa disseram não passar dever de casa porque "eles [os alunos] não fazem mesmo". Na escola Lírio, uma professora disse que sempre passa dever, mas que não obtém um resultado positivo porque os alunos não fazem a tarefa em casa, e complementa: "eles não têm essa cultura, não. A família deixa muito solta.”

$\mathrm{Na}$ escola Girassol, uma professora afirmou que, ao invés de passar dever de casa, prefere passar atividades de pesquisa, e disse ter um bom retorno em relação a essa tarefa: "eles sempre trazem alguma informação ou notícia sobre o tema trabalhado. Mesmo os que não têm Internet em casa, trazem alguma notícia de jornal ou de revista..."

Apesar de serem recorrentes os achados de pesquisas que afirmam que a prática de passar e corrigir dever de casa tem um impacto positivo e significativo no desempenho escolar dos estudantes, observou-se, nas turmas dessas escolas, que essa prática não é tão frequente, embora os professores afirmassem, salvo nas exceções citadas, que passam e corrigem o dever frequentemente. Esta afirmação se apoia no fato de das catorze professoras entrevistadas, três terem afirmado não passar o dever de casa porque os alunos não o fazem. Entretanto, os alunos não atendem ás demandas relacionados ao dever de casa por motivos que são desconhecidos pelas professoras. Com isso, os alunos não desenvolvem o hábito de estudar em casa.

\section{CUMPRIMENTO DO CURRICULO}

O cumprimento do currículo também é uma categoria de análise reportada pela literatura como uma característica que influencia positivamente na aprendizagem. O planejamento das aulas com base no currículo definido pela escola e/ou rede de ensino, de forma a cumprir toda a extensão do conteúdo, tem 
um efeito positivo no desempenho dos alunos e é reportado pela literatura como um dos aspectos das escolas eficazes (BROOKE e SOARES, 2008)

Os pedagogos da escola Tulipa afirmaram que o currículo trabalhado na escola é definido com base no currículo estabelecido pela Secretaria Municipal de Educação, nos Parâmetros Curriculares Nacionais e nos livros didáticos. Eles não souberam dizer exatamente quanto tempo da carga horária escolar é dedicada a cada matéria, mas afirmam que um maior tempo de aula é dedicado a Português e Matemática. Apesar disso, nesta escola, apenas uma professora - a mesma que passa e corrige dever de casa - afirmou completar $100 \%$ do planejamento curricular. As demais afirmaram que não conseguirão cumprir com o planejamento até o final do ano letivo, sendo que uma professora garantiu que dará apenas $70 \%$ do conteúdo programado.

Das quatro professoras do $3^{\circ}$ ano, ela é a única "DT", termo que significa designação temporária e que se refere aos professores contratados. Durante a entrevista, essa professora se queixou da direção da escola e dos demais colegas, afirmando que recebe um tratamento desigual justamente por ser DT. Disse que participa apenas presencialmente, mas que não tem voz na construção do Projeto Político Pedagógico da escola. Por mais de uma vez, durante a entrevista, disse que todos os "pepinos" caem na mão dela, fazendo referência ao aluno esquizofrênico que está alocado na sua turma e que tem uma mediadora que o acompanha de forma irregular. Afirmou, também, que as regras disciplinares da escola são muito severas e que tem pena dos alunos, pois "eles são muito presos". "Se [o aluno] gritar no recreio, fica de castigo. E qual é o castigo? Ler. Como uma criança vai gostar de ler, se ler é o castigo?"

Nas aulas observadas, essa professora trabalhou com a confecção de material reciclado. A partir de garrafas pet, os alunos produziriam um puf que seria apresentado na amostra cultural - um evento em que há apresentação das diversas atividades realizadas pelos alunos ao longo do ano. Essa amostra cultural é um evento da Secretaria Municipal de Educação, no qual todas as escolas da rede participam. Cada escola define seu próprio tema e, ao longo do ano letivo, os professores elaboram com seus alunos diversas atividades que serão apresentadas para a comunidade escolar (gestores educacionais, professores, pais e funcionários). A aula observada tratou de atividades lúdicas, que exercitavam a 
criatividade e a coordenação motora, uma vez que exigiam o manuseio de materiais: corte, colagem e pintura das garrafas e também raciocínio lógico, pois os alunos precisaram pensar como deveriam encaixar as garrafas para formar o puf. Nessa situação, foi observada um conflito que gerou certo mal-estar. Durante a realização da tarefa, a professora de artes foi "dar uma olhada" no que os alunos estavam fazendo e uma aluna comentou: "isso que estamos fazendo é que é artes." A professora rebateu: "Não é não. Isso é artesanato." E complementou: "Sabe porque eu não faço isso com vocês? Porque depois eu que tenho que limpar tudo e eu não sou faxineira da escola.”.

Essa aula abordou o tema da reciclagem, relacionado ao tema do meio ambiente, que, segundo a professora, vinha sendo trabalhado desde o início do ano. Além disso, durante a aula, a professora trabalhou Matemática (adição e subtração) ainda que de forma bem rápida e sem um grau de dificuldade elevado, com o intuito de mostrar aos alunos como encaixar uma garrafa na outra para montar o puf.

Nas demais aulas, os conteúdos mais trabalhados foram, de fato, Português e Matemática, e em todas as aulas as professoras utilizaram os materiais didáticos tradicionais: livros didáticos, cópia do quadro e folhinhas de exercícios.

$\mathrm{Na}$ escola Rosa, a pedagoga informou que a Secretaria Municipal de Educação estabelece o currículo para a etapa da escolarização correspondente ao segundo segmento do Ensino Fundamental, não havendo currículo para os anos iniciais do Ensino Fundamental. O currículo trabalhado na escola está pautado no livro didático e nos "enchertos" (sic) que são feitos com base no diagnóstico realizado no início do ano com os professores. Uma das professoras ressaltou que o conteúdo é definido com base naquilo que o aluno já sabe, a partir de uma avaliação diagnóstica que é feita no início do ano. Apesar disso, não há nenhuma orientação, apoio e diálogo por parte da equipe pedagógica em relação ao currículo a ser trabalhado. Cada professor, define o conteúdo que irá trabalhar, e isso é feito, principalmente, com base no livro didático e na avaliação diagnóstica. Essa professora afirmou cumprir em torno de $60 \%$ do conteúdo que programou no início do ano, e trabalhar prioritariamente Português e Matemática e raramente as outras disciplinas. Por outro lado, a professora que assumiu a turma em setembro, afirmou que, desde sua chegada à escola, não teve acesso ao currículo, nem ao 
Projeto Político Pedagógico. Disse que somente dá continuidade aos conteúdos já trabalhados pela professora anterior, mas afirmou ser atendida sempre que solicita material para trabalhar. Não soube dizer qual a porcentagem do currículo que conseguirá cumprir. Disse apenas que prioriza Português e Matemática.

Nesta escola, uma turma recebe aulas de reforço. Entretanto, chama a atenção a maneira como as mesmas são operacionalizadas: em um tempo de aula, os alunos avançados vão para a sala de outra professora e os alunos atrasados ; com dificuldade (7 no total) ficam em sala com a professora regente da turma, tendo aula de reforço, que consiste na continuação da atividade que já estava sendo realizada por todos os alunos. No caso observado, exercícios de português numa folhinha.

$\mathrm{Na}$ outra turma da escola Rosa foi observada algumas improvisações. Por exemplo, embora estivesse planejada uma provinha de português, a coordenação da escola não tinha providenciado as cópias. Então, enquanto aguardava as cópias, a professora pegou um livro e o leu para os alunos. A história era sobre racismo. Após a leitura, a professora fez algumas perguntas com a finalidade de promover um debate, que foi logo interrompido quando uma funcionária da coordenação chegou com as provas. Alguns alunos não tinham lápis nem borracha. A professora solicitou o material à coordenação.

$\mathrm{Na}$ escola Rosa, foi possível perceber outros indícios de certo descaso com o processo de ensino-aprendizagem. A escola tem biblioteca, que fica fechada por falta de funcionários. Nas salas de aula, há armários com alguns livros mas os alunos não têm acesso a eles porque o material fica trancado. A justificativa é que "os alunos destroem os livros". Eles são usados apenas pelas professoras, para lerem para os alunos. Também foram observadas atividades que não pareceram adequadas para o ano escolar cursado. Por exemplo, uma das folhinhas de exercícios propunha a seguinte atividade:

Quantas vezes abrimos a boca para falarmos as seguintes palavras?

$$
\begin{gathered}
\text { Viviana - } \square \\
\text { Girafa - } \square \\
\text { Urso - } \square \\
\text { Pijama - } \square \\
\text { Jacaré - }
\end{gathered}
$$




$$
\begin{gathered}
\text { Pinguim }- \\
\text { Leão }-\square \\
\text { Macaco - } \square \\
\text { Polvo - } \square
\end{gathered}
$$

Essa atividade é inadequada pois avaliada a consciência silábica e fonêmica dos alunos ao solicitar-lhes que identifique as sílabas e os sons das palavras. Trata-se, portanto de uma habilidade a ser desenvolvida no início do ciclo de alfabetização, como uma das primeiras aprendizagens a serem consolidadas pelos alunos com vistas à sua plena alfabetização no final do $3^{\circ}$ ano, como sugere a meta 5 do PNE. Portanto, a atividade pedagógica visando ao desenvolvimento desta habilidade nesta etapa do ensino pode ser entendida de duas maneiras, ou se trata de uma atividade que desenvolvida intencionalmente com o objetivo de rever conhecimentos que já deveriam estar consolidados, uma vez que os alunos ainda não dominariam plenamente a contagem de sílabas de palavras com diferentes padrões silábicos e, portanto, não estriam plenamente alfabetizados no final do $3^{\circ}$ ano, ou se trata de uma atividade inadequada e proposta sem um objetivo pedagógico claro.

$\mathrm{Na}$ escola Girassol, o currículo adotado é definido pela Secretaria Municipal de Educação de Serra. Segundo a pedagoga, o planejamento curricular é feito por cada professor e leva em consideração também os resultados da avaliação diagnóstica realizada no início do ano. Ela explica: “A SEDU tem uma proposta de conteúdos mínimos, conteúdos curriculares para cada área do conhecimento. Aí a gente já 'traça' o plano de ensino. Cada professora faz o seu. No início do ano, a gente faz uma avaliação diagnóstica. Aí acontece do professor planejar, fazer o plano de ensino, mas aí, com base na avaliação diagnóstica ele diz: Epa! Vou precisar mudar isso. Vou precisar mudar aquilo, porque na minha avaliação diagnóstica eu detectei que meu aluno ainda não consolidou isso - que até é matéria do ano anterior, mas ele não consolidou. Então, vou inserir isso no meu plano de ensino. Então, isso acontece muito. Por isso, o planejamento precisa ser flexível."

Além das disciplinas escolares obrigatórias, essa escola também oferece aula de inglês, disciplina que foi incorporada ao currículo; 2014 foi o primeiro ano 
em que as escolas ofereceram inglês para os alunos, nos anos iniciais do Ensino Fundamental. Essa disciplina não reprova, mas os alunos fazem prova, são avaliados. Segundo a pedagoga, os alunos e as famílias receberam bem a inclusão dessa disciplina na grade curricular.

Nesta escola, todas as professoras afirmaram terem cumprido todo o conteúdo curricular planejado de todas as disciplinas e que dedicam uma carga horária maior para Português e Matemática. Todas as aulas observadas se referiam à essas duas disciplinas. Como a investigação de campo nessa escola ocorreu em dezembro, as atividades didático-pedagógicas tinham um caráter de revisão e a dinâmica das aulas era mais extrovertida.

$\mathrm{Na}$ escola Lírio, o currículo trabalhado é definido pela Secretaria Municipal de Educação de Serra, mas os professores têm autonomia para acrescentar outros conteúdos. Cada professora define a carga horária de cada disciplina, mas a prioridade é dada a Português e a Matemática. A pedagoga do turno da tarde revisa trimestralmente o plano de curso com as professores e faz as adaptações que cada turma necessita. Segundo a pedagoga, cada turma tem um plano de curso específico. Ela explica: "A gente senta, conversa e faz dois planos de curso diferentes. Porque uma turma está de um jeito, a outra está de outro jeito. Por exemplo, nessa turma eu ainda tenho que continuar com a soma e subtração.Mas com aquela, já posso ir para multiplicação. Então, a gente tenta fazer com cada turma o seu plano de curso".

Nesta escola, duas professoras conseguiram cumprir o plano de curso estabelecido para todas as disciplinas. Uma professora afirmou não ter conseguido trabalhar todo o conteúdo de Matemática e que os alunos passariam para o $4^{\circ}$ ano sem terem aprendido divisão. Outra professora disse que cumpriu em torno de $70 \%$ do conteúdo programado, que prioriza Português e Matemática e que não passa atividades de pesquisa porque a pedagoga não gosta. A professora declarou que todo o conteúdo a ser ensinado e a metodologia a ser adotada nas aulas passam pelo crivo da pedagoga e que não há nada que ela faça que não tenha o aval dessa profissional. Além disso, disse que o currículo é montado com base no livro didático e que não recebeu/não sabe quais são as orientações curriculares da Secretaria. 
Em todas as aulas observadas, os conteúdos trabalhados foram de Português e Matemática. Apenas em duas turmas do turno da manhã, os alunos também fizeram várias atividades de uma apostila sobre normas de trânsito - tema transversal que a Secretaria oferece para ser trabalhado nas escolas, mas que as professoras não souberam dizer se é obrigatório. Segundo os depoimentos das professoras, teria sido uma recomendação da pedagoga que elas acataram.

\section{RESPONSABILIDADE PELO APRENDIZADO DOS ALUNOS}

O sentimento de responsabilidade pelo aprendizado é frequentemente reportado pela literatura em eficácia escolar como um dos fatores associados a um bom desempenho cognitivo nos testes em larga escala, como mostram os estudos de Espósito, Davis e Nunes (2000), Albernaz, Ferreira e Franco (2002) e Lee, Franco e Albernaz (2004) e Alves e Franco (2008).

No presente estudo, foi observado nos professores e na equipe pedagógica de todas as escolas, com exceção da escola Rosa, um senso de responsabilidade pelo aprendizado dos alunos. O mesmo se mostrou mais forte nas escolas Tulipa e Lírio, nas quais os professores lançavam mão de diversas metodologias e dos recursos didático-pedagógicos disponíveis para garantir o aprendizado dos estudantes.

Em uma turma do turno da manhã da escola Tulipa, a professora dedicava uma atenção especial aos alunos com dificuldade: enquanto os alunos da turma faziam uma atividade cada um em sua mesa, a professora chamou os três alunos não alfabetizados até a sua mesa, os colocou sentados próximos a ela e passou outro tipo de atividade, observando de perto e fazendo junto com eles os exercícios.

No turno da tarde, essa escola oferece aulas de reforço para os alunos com dificuldade e/ou não alfabetizados. As aulas são dadas pelo pedagogo da escola no refeitório, único lugar disponível para a realização das aulas no horário regular. Ou seja, os alunos com dificuldade são tirados da sala de aula regular para assistir aulas de reforço no refeitório. Embora o espaço e o horário não sejam adequados, as duas professoras do turno da tarde e o pedagogo afirmaram que estavam conseguindo obter resultados positivos e que os alunos que frequentavam as aulas de reforço teriam melhorado seus desempenhos escolares. 
$\mathrm{Na}$ escola Rosa, a existência de um senso de responsabilidade pelo aprendizado dos alunos não foi manifestado claramente pelas professoras. Ao contrário, por diversas vezes, foi percebido um sentimento penoso, que demonstrava que elas estavam naquela escola por falta de opção e que sentiam estar "fazendo um favor" à escola e aos alunos. Uma das professoras assumiu a turma em setembro, temporariamente, com a função de "quebrar um galho", pois, no ano seguinte, voltará a ser locada na Secretaria e a escola terá que providenciar outra professora. Disse que os alunos têm uma "realidade muito dura, muito difícil", mas que faz "o que pode" para ajudar "os meninos" a aprender alguma coisa. Já a outra professora demonstra um grande carinho pelos alunos, os chamando frequentemente por "meu amor" e fazendo carinhos e afagos. No entanto, apesar dessas boas relações afetivas, as atividades que a professora propôs aos alunos foram pouco desafiadoras> ela afirmou se sentir desmotivada pois, segundo seu depoimento durante a entrevista, não recebe apoio da equipe pedagógica. Durante a realização das tarefas em sala de aula, a professora atendeu aos pedidos de ajuda e tirou as dúvidas somente quando os alunos foram até a mesa dela. A professora não circulou pela sala e nem ofereceu ajuda. Manteve, assim, uma postura passiva, relacionando apenas quando um aluno manifestava alguma dúvida/dificuldade. Na entrevista, tal observação foi corroborada quando a professora afirmou acompanhar as tarefas realizadas só quando o aluno apresenta dúvidas. Segundo a professora, ela "não confere" o que fazem os alunos "autônomos".

Na escola Girassol, a pedagoga, a diretora e todas as professoras afirmaram que se sentem responsáveis pelo aprendizado dos alunos, embora isso não tenha sido percebido durante as observações, que só puderam ser realizadas no fim do ano - mês de dezembro -, quando todo o conteúdo programático e as avaliações finais já tinham sido cumpridos. As aulas ainda eram dadas apenas para atendimento da disposição legal que fixa o número total de dias letivos, apesar de a maioria dos alunos não as frequentarem.

Segundo a pedagoga, a equipe pedagógica, em conjunto com as professoras, faz um acompanhamento bem rigoroso das crianças com dificuldade de aprendizagem. Em sua fala, ela relata um exemplo de ação que mostra a dedicação da equipe para procurar descobrir as causas do não aprendizado dos 
alunos: “Teve uma professora aqui que tentou 'n' situações para acriança aprender a ler e escrever. Quando você fazia as perguntas, para ele de forma oral, ele te respondia tudo, mostrando que ele assimilou o conteúdo. Mas quando partia para a questão da leitura e da escrita propriamente dita, você via um bloqueio, uma dificuldade. Aí, primeiro, a professora usou todo tipo de estratégia que você possa imaginar. Nada da criança ler e escrever. Por fim, depois de conversar com a mãe do aluno - que também é professora - procurou um neurologista. Foi descoberto que o aluno tem dislexia. E aí realmente existe, né? A criança com dislexia tem muita dificuldade, principalmente em relação à escrita. Então assim, antes da gente chegar a falar para família assim: 'Ó, procura um médico', todo o tipo de recurso pedagógico, didático, que está em nossas mãos, a gente usa.”

$\mathrm{Na}$ escola Lírio, apesar de também se localizar numa região de alta vulnerabilidade social e ter que conviver com casos frequentes de violência, as professoras da escola assumem uma postura mais ativa diante do processo de ensino-aprendizagem. Isso pôde ser percebido pela fala das pedagogas e das professoras nas entrevistas, bem como no zelo que elas têm com o material didático dos alunos e com as cobranças frequentes de realização das tarefas. Todas as professoras convidavam constantemente os alunos a participarem das aulas, indo ao quadro resolver a atividade ou dando as respostas oralmente. Elas sempre circulam pela sala, observando os alunos realizarem as tarefas e, por vezes, dando algumas explicações sobre o conteúdo que eles estavam estudando.

\section{ABSENTEÍSMO DOCENTE}

A ausência e/ou afastamento dos professores de suas atividades é encarada de forma consensual por parte dos professores e, principalmente da equipe pedagógica, como um fator que prejudica o desenvolvimento da aprendizagem dos alunos.

Durante as visitas às escolas, não se registrou nenhuma ausência de professores nas turmas do $3^{\circ}$ ano. Nas escolas Tulipa e Rosa, segundo os depoimentos recolhidos durante as entrevistas, quando um professor precisa faltar, os alunos são distribuídos em outras turmas, que não são necessariamente, do mesmo ano escolar. Ou seja, se uma professora do $3^{\circ}$ ano faltar, os alunos são distribuídos em outras turmas, do $3^{\circ}$ e/ou do $4^{\circ}$ ano. Além disso, todas as 
professoras fazem um baú com atividades para serem realizadas pelos alunos, quando eles estão provisoriamente alocados em outras turmas/séries. Em situações em que mais de uma professora falta no mesmo dia, a pedagoga entra em sala de aula, sempre trabalhando com as atividades que estão no baú montado pela professora regente. Por outro lado, quando a falta é justificada por atestado médico, a direção liga para a Secretaria e eles enviam um professor substituto para assumir a turma durante o afastamento do professor.

$\mathrm{Na}$ escola Girassol, a direção da escola tem recurso em caixa escolar para pagar professores substitutos quando os professores regentes precisam faltar. Entretanto, foram relatados casos em que foi preciso dispensar as turmas, porque não foi possível contatar um professore substituto. Nessa escola, uma turma do $3^{\circ}$ ano teve, ao longo do ano letivo, quatro professoras. A pedagoga explicou que a turma iniciou 2014 com uma professora que foi contratada para cobrir a licença maternidade de uma professora efetiva. Quando findou a licença maternidade, a professora retornou à ativa e foi alocada, pela Secretaria, na escola Girassol. Segundo a pedagoga, quando um professor efetivo retorna de licença e não há vaga em nenhuma escola, ele tem o direito de ficar no lugar de uma contratada. A professora efetiva foi para escola Girassol com o posto de "locação provisória" e a professora contratada ficou aguardando surgir outra vaga na rede, mas o contrato dela não foi rescindido. Entretanto, existiria, nas falas das entrevistadas, uma professora efetiva que seria a "dona da cadeira", ou seja, o posto de trabalho dessa professora é na escola Girassol mas ela estava trabalhando em um projeto da SEDU e voltou desse projeto no meio ano. "Aí, a professora efetiva "dona do posto" tem prioridade sobre a efetiva em 'locação provisória"'. Com isso, a Secretaria transferiu a professora "em locação provisória" para outra escola e a professora "dona do posto" assumiu a turma. Após algum tempo, no entanto, um dos coordenadores pedagógicos da escola recebeu um convite para trabalhar na Secretaria de Educação e ele aceitou. Novamente, a diretora precisou substituir o coordenador que, nesse caso, não pode ser contratado porque precisa ser um profissional efetivo da rede. A professora efetiva, "dona da cadeira” aceitou assumir a coordenação e, então, a Secretaria enviou uma nova professora contratada para ficar com a turma. Para a pedagoga, essa rotatividade de professores teve um impacto negativo sobre o desempenho dos alunos, pois a 
turma ficou desmotivada. Ela explica: "mas é algo que está além das nossas questões de ordem pedagógica. São questões administrativas. Nós não temos culpa se o coordenador aceitou um convite para ir para lá, nós não temos culpa se o professor que veio tem direito em relação ao contratado. Então, são questões de ordem administrativa, mas que afetam sim o desempenho (...). A turma foi afetada na autoestima, a turma foi afetada em uma série de questões, sim."

$\mathrm{Na}$ escola Lírio, quando um professor tem um imprevisto e precisa faltar, os alunos vão para a biblioteca ou para a sala de informática e a pedagoga passa uma atividade para eles. Quando é o caso de um atestado médico, e o professor se ausenta por mais de 03 dias, a escola paga com o dinheiro que tem em caixa um professor substituto. Mas se a ausência for superior a 10 dias, a Secretaria desloca um professor substituto para a escola. Segundo as pedagogas, há um alto absenteísmo docente na escola e isso prejudica muito o desenvolvimento da aprendizagem.

\section{COLABORAÇÃO DOCENTE}

A colaboração docente compõe os 11 fatores elencados por Sammons (apud BROOKE e SOARES, 2008) como uma característica das escolas eficazes. Esse fator é frequentemente associado a um bom desempenho nas avaliações em larga como mostra os estudos de PEDROSA (2007), POLON (2009) e MUYLAERT (2012).

Nas quatro escolas observadas, os professores interagem, trocam ideias e informações formal e informalmente apenas com os colegas do mesmo turno. Não há encontros e nem discussões com professores de turnos diferentes. Os professores também não planejam coletivamente suas aulas. O planejamento é feito individualmente pelo professor com o apoio dos pedagogos. A única exceção é a escola Tulipa, onde as professoras do $3^{\circ}$ ano do turno da tarde se reúnem uma vez na semana para planejar juntas as aulas. São as únicas professoras com um horário programado para discutir e planejar aulas, embora não recebam muito apoio do pedagogo. Nessa mesma escola, as professoras do $3^{\circ}$ ano do turno da manhã quase não dialogam e não sabem têm conhecimento do trabalho pedagógico das colegas. Apesar disso, ambas disseram receber total apoio da pedagoga do turno da manhã. 
$\mathrm{Na}$ escola Rosa, uma professora disse que faz seu planejamento individualmente, sem apoio dos colegas e da equipe pedagógica. Raramente solicita material à equipe pedagógica e usa como recursos didático-pedagógicos o material disponibilizado no curso do PNAIC. Por outro lado, a outra professora do $3^{\circ}$ ano afirmou planejar suas aulas individualmente, mas disse receber apoio da pedagoga e sempre receber o material didático pedagógico que solicita, embora reconheça que a escola tem poucos recursos e por isso não pode fazer uso de bons materiais, bons livros.

$\mathrm{Na}$ escola Girassol, as quatro professoras do $3^{\circ}$ ano atuam no turno da tarde. O planejamento é individual e recebem apoio da equipe pedagógica. Às vezes as professoras planejam junto com aos professores de artes, inglês e informática, de modo a trabalhar os mesmos conteúdos, mas raramente fazem este trabalho em conjunto com as demais colegas do $3^{\circ}$ ano ou de outros anos escolares. Há, no entanto, trocas informais de ideias, informações e materiais.

$\mathrm{Na}$ escola Lírio, as professoras do $3^{\circ}$ ano da manhã e da tarde possuem um horário de planejamento conjunto, mas todas realizam esse planejamento individualmente, dialogando apenas com as pedagogas. Observou-se que os professores de ambos os turnos possuem bom relacionamento. A maioria chega antes do horário e fica na sala dos professores conversando informalmente. São afetuosos, dão risadas, trocam informações, conversam sobre os alunos e sobre questões sindicais. Pôde-se perceber que, embora o planejamento das aulas seja feito de forma individual, há trocas informais de ideias, informações e materiais.

\section{ORGANIZAÇÃO DAS TURMAS}

A forma de organização das turmas é um dos aspectos que ajudam a explicar as desigualdades intraescolares. Os estudos de Soares (2005), Alves e Soares (2007), Alves e Franco (2008) e Costa (2008) encontraram efeitos significativos das turmas sobre a variação do desempenho dos alunos.

Segundo Costa e Koslinski (2011), as escolas fazem uso de mecanismos internos que separam os alunos por habilidades ou interesses, formando classes homogêneas, que permitiriam melhores resultados médios.

Nas escolas investigadas, segundo os depoimentos de seus profissionais, com exceção da escola Girassol, as turmas são formadas no $1^{\circ}$ ano, quando as 
crianças chegam à escola, e se mantém com a mesma composição até o $5^{\circ}$ ano. Nenhum professor soube dizer como as turmas são formadas, pois eles não participam dessa atividade escolar. Quem distribui os alunos nas turmas é a equipe pedagógica junto com a direção.

No entanto, essa manutenção da composição da turma nem sempre se confirma Segundo a diretora da escola Tulipa, no $1^{\circ}$ ano, não há critérios de enturmação: forma-se uma turma e se houver demanda abre-se outra, enfatizandose a ordem de chegada. No entanto, a mesma diretora admite que, ao longo da escolarização, os alunos são remanejados por dois motivos: 1) quando o professor sugere que algum aluno troque de turma por motivos de comportamento e indisciplina; nesses casos, a diretora costuma acatar a indicação do professor; 2) quando os pais pedem que o aluno mude de turno.

$\mathrm{Na}$ escola Rosa, os alunos são enturmados por idade e por gênero. Alegando que uma turma precisa ter mais ou menos $50 \%$ de meninos e $50 \%$ de meninas, a diretora complementa: "uma turma com muito menino dá medo". Uma vez que as turmas são formadas o $1^{\circ}$ ano, elas se mantem até o $5^{\circ}$. No entanto, mais uma vez, a diretora declara que, se houver casos de mal comportamento e indisciplina, a escola muda os alunos de turma.

Já na escola Girassol, os alunos são remanejados ano a ano segundo o nível de desempenho e indisciplina. A ideia da equipe pedagógica não é montar turmas homogêneas. Pelo contrário, com essa prática pretende-se montar turmas com alunos de níveis de aprendizagem diferentes. A pedagoga explica: "a gente tem sim que mesclar as turmas porque todo professor vai ter que fazer trabalho diferenciado (...) A gente defende sim, uma turma mesclada para não estigmatizar nossos alunos. Então, a formação das turmas, a partir de agora, a gente pretende fazer isso. Por que? Porque aí vão acontecer vários fatores positivos em montar turmas heterogêneas. Os alunos não vão ficar estigmatizados: 'Ah! Aquela lá é a turma dos fracos, aquela lá é a turma dos fortes. Não vai acontecer isso. E outra coisa: 'Ah! Aquele professor tá fácil pra ele. Eu peguei uma turma mais difícil'. Não vai acontecer. Todo mundo vai ter que fazer trabalho diversificado."

Além de reagrupar os alunos segundo os níveis de aprendizagem, a escola também considera o gênero, tentando compor turmas com um número equilibrado de meninos e meninas. A diretora se diz contra a ideia de formar turmas fracas e 
turmas fortes. Entretanto, para o $8^{\circ}$ ano, o conselho da escola decidiu reenturmar os alunos de acordo com o nível de aprendizagem formando uma turma A ("forte") e duas turmas B ("razoáveis"). A diretora se posicionou contra essa ideia, mas foi voto vencido. Ela explica: "Eu particularmente não gosto da ideia. Mas fui voto vencido. Você tá entendendo? (...) Porque os professores disseram: Não, a gente não vai formar uma boa, uma mais ou menos e uma ruim. A gente vai formar uma boa e duas razoáveis. Então’, vamos tentar. É uma experiência nova."

$\mathrm{Na}$ escola Lírio, as turmas são formadas no $1^{\circ}$ ano e seguem juntas até o $9^{\circ}$, embora aqui também existam casos de troca de alunos por motivos de indisciplina. Também é importante ressaltar que a maneira como os alunos são distribuídos nas turmas muda de acordo com o turno escolar. No turno da manhã, as turmas são formadas com base na idade. A pedagoga explica: "Esse ano nós tivemos uma dificuldade com o segundo ano porque era uma turma que tinha alguns repetentes e a gente não quis misturar com esses alunos daqui por causa da idade, da maturidade (...) Porque já era uma turma mais avançada e a gente fica preocupado de colocar os alunos maiores com os menores (...). Tem que ter cuidado com essa questão do que está ouvindo, do que está levando para casa. Foi esse ano que a gente teve um problema assim.Mas, fora isso, a gente mistura, mistura para poder estar acabando com os problemas realmente."

No turno da tarde, as turmas são formadas por ordem de chegada. Os alunos se matriculam e formam uma turma. Havendo demanda, abre-se outra turma e assim por diante. Em 2014, a escola teve cinco turmas de $1^{\circ}$ ano: 2 à tarde e 3 de manhã. Em 2015 também foram cinco turmas, sendo 3 à tarde e 2 de manhã.

\section{QUALIDADE DOCENTE}

De acordo com Oliveira et al (2013), o efeito da qualidade docente dos professores na aprendizagem dos alunos pode ser averiguada de acordo com dois aspectos que podem, ou não, se complementar: a formação e a distribuição desses profissionais nas turmas. Um professor pode ser avaliado como "bom" pela sua formação e pela sua experiência. E a alocação desse profissional nas turmas pode seguir esses critérios ou não. 
Tradicionalmente, no Brasil, os professores escolhem as turmas em que desejam lecionar e, normalmente, os mais antigos na escola escolhem primeiro, relegando os mais novos (e, provavelmente menos experientes) às turmas que não foram escolhidas. Isso pôde ser observado nas escolas investigadas, como se verá a seguir. De um modo geral, a alocação dos professores nessas turmas não segue critérios objetivos, como, por exemplo, o desempenho dos alunos no PAEBESAlfa. A alocação se dá com base em critérios subjetivos, que atendem principalmente o desejo de cada professor.

Os dois aspectos que compõe a categoria qualidade docente (OLIVEIRA et al, 2013) foram investigados nas escolas.

\section{- FORMAÇÃO}

Todos os professores e pedagogos possuem graduação e, pelo menos uma, pós-graduação na área de educação. Uma professora afirmou ter cinco cursos de pós-graduação. Já as diretoras, possuem apenas curso de licenciatura: uma é formada em Pedagogia, outra em Pedagogia e Artes e a outra em Educação Física.

Apesar de todas possuírem titulação na área profissional e em nível superior, foi possível perceber, por meio das observações realizadas, que a qualidade dessa formação não é satisfatória. Durante as observações das aulas, algumas professoras cometeram erros que denunciaram a baixa qualidade da formação e que comprometem sua competência para o exercício do magistério. Em uma das aulas, por exemplo, a professora passou uma atividade de português no quadro, escrevendo as palavras cenoura e repouso de forma errada. Cenoura foi escrito sem "u" (cenora) e repouso foi escrito com "l" no lugar do "u" (repolso). Um dos alunos corrigiu a professora, alertando-a de que palavra cenoura tinha "u”, enquanto o erro na grafia da palavra repouso . Essa mesma professora não mostrou fazer um bom uso da linguagem oral e escrita, ao dirigir-se frequentemente aos alunos com falas cheias de deboches, ironias e ameaças. Por exemplo, a professora passou algumas atividades de matemática que consistiam na resolução de problemas que envolviam a operação de multiplicação. Enquanto alguns alunos realizavam a tarefa, outros conversavam. Foi então que a professora se dirigiu a um aluno que conversava e falou: "se você não fizer a atividade, você 
vai ver..." E complementou: "Além de não fazer nada, ainda atrapalha os que querem fazer".

Em outra sala de aula, a professora apresentou vícios de linguagem: com frequência, a professora utilizou expressões como "pra mim fazer", "pra mim corrigir", "pra mim descer pro recreio" etc. Foi observado, também, que alguns de seus alunos reproduziam essa linguagem inadequada e que outras professoras da escola cometiam esse tipo de erros, embora com uma frequência menor.

\section{- DISTRIBUIÇÃo (ALOCAÇÃO DOS PROFESSORES NAS TURMAS)}

Na escola Tulipa, a diretora alocava os professores nas turmas de acordo com o perfil de cada um. Essa decisão era tomada pela diretora, sem a participação de nenhum membro da equipe pedagógica no processo de escolha. Entretanto, a diretora afirmou que antes de decidir qual professora iria ficar em determinada turma, ela perguntava as preferências de cada uma. Apesar disso, existiriam algumas professoras que, segundo o depoimento da diretora, ela "não troca de jeito nenhum". Uma professora do $3^{\circ}$ ano do turno da tarde lecionava há 6 anos no $3^{\circ}$ ano escolar e a diretora não deixava ela mudar, alegando que teria o perfil para lecionar no $3^{\circ}$ ano.

$\mathrm{Na}$ escola Rosa, houve uma divergência. Por um lado, a professora de uma das turmas afirmou que é a pedagoga que distribuiria os professores nas turmas. Por outro lado, a pedagoga informou que seriam os professores quem escolheriam em que turmas trabalhar, sendo que os professores mais antigos escolheriam primeiro. A professora, que chegou à escola apenas em setembro, não soube responder quais seriam os critérios de alocação dos professores nas turmas.

$\mathrm{Na}$ escola Girassol, segundo a diretora, seriam os professores que escolheriam as turmas, quem escolheria primeiro seriam aqueles com mais tempo de serviço efetivo na rede. Entretanto, a pedagoga informou que, embora cada professor manifestasse o desejo de trabalhar em determinada turma, a equipe pedagógica também avaliaria o perfil de cada um e tentaria conciliar o desejo e o perfil de cada professor.

Já na escola Lírio, o processo de distribuição dos professores nas turmas se daria de outra forma: eles se reuniriam previamente e discutiriam quais turmas 
querem assumir. Posteriormente feita uma reunião com a diretora, na qual eles manifestariam suas respectivas escolhas. As decisões quanto à alocação das professoras nas turmas seriam tomadas nessa reunião. A pedagoga do turno da tarde diz não interferir nesse processo "eu prefiro não me meter, porque ano que vem, se tiver qualquer problema, eu tenho que ajudar a resolver e eles vão me cobrar: 'Ah você que induziu a gente a estar pegando a turma.' Por isso, eu prefiro que elas resolvam entre si sem a minha interferência." No caso dos professores contratados, eles ficariam com as turmas sobrantes, aquelas que nenhum professor efetivo quis assumir. Nessa escola duas professoras do $3^{\circ}$ ano eram contratadas, uma no turno da manhã e outra a tarde.

\section{USO DO TEMPO}

O uso do tempo destinado à aprendizagem é uma categoria de análise levantada por Crahay (2002) como uma das principais características referentes à igualdade de conhecimento, conforme visto no capítulo1. Alguns estudos (SLAVI, 1997; PEDROSA, 2007, CARNOY, 2009, BRUNS, EVANS e LUQUE, 2012) mostram a associação positiva entre o tempo efetivamente dedicado à aprendizagem e o desempenho dos alunos nas avaliações.

Segundo todas as professores, pedagogos e diretoras, há um maior tempo de ensino dedicado às matérias de língua portuguesa e Matemática.

A grade de horário observada em todas as escolas mostra que há um maior tempo dedicado às aulas dessas áreas curriculares, sendo a carga horária de geografia, história e ciências reduzida. Além dessas disciplinas, há também horários reservados para as aulas de educação física, artes e informática. As escolas do município de Serra também oferecem aulas de inglês.

Embora as professoras dediquem maior tempo ao ensino de português e de Matemática, uma professora da escola Lírio afirmou que concluirá todo o conteúdo planejado de história, geografia, ciências e português, mas não conseguirá concluir o conteúdo de Matemática. Os alunos dessa turma seguiriam para o $4^{\circ}$ ano sem ter aprendido a divisão - uma das quatro operações básicas da Matemática. Inclusive, por esse motivo, a professora já havia manifestado à pedagoga o desejo de ir com essa turma para o $4^{\circ}$ ano, pois ela afirmou ter um sentimento de que "deixou o trabalho incompleto". Essa professora é efetiva nessa 
escola, mas estava alocada na direção de outra escola para "cobrir" a licença de uma profissional. No mês de agosto, ela retornou para o seu "posto de origem". Ou seja, assumiu a turma no meio do ano letivo, que até aquele momento estava sob a regência de uma professora contratada.

Nas observações nas turmas, as aulas eram sempre de português ou Matemática. Nas aulas de informática que foram observadas, o conteúdo trabalhado também foi de Matemática. À exceção da escola Tulipa, nas outras escolas, não foram observadas aulas de história, de geografia e de ciências.

Durante as visita às escolas, notou-se que parte considerável do tempo escolar dedicado às atividades didático-pedagógicas é desperdiçado em função de interrupções, pausas, deslocamento dos alunos para as aulas de educação física e informática, retorno do recreio e entrada na escola. Todas as escolas realizam diariamente um ritual de entrada: os alunos chegam à escola e se dirigem diretamente para o ginásio, onde formam filas e rezam a oração do Pai Nosso. Na escola Tulipa, às quintas-feiras, além da oração há também o canto do hino nacional. Por causa desse ritual, o início efetivo da aula acontece entre 10 e 20 minutos após a chegada dos alunos à escola.

As interrupções da aula acontecem por vários motivos: chamar a atenção dos alunos por indisciplina, providenciar material de trabalho, dar/receber recado da coordenação, entrada em sala de professora de outra turma solicitando alguma informação ou material pedagógico e, também, para distribuição de frutas aos alunos. Essa interrupção foi observada numa turma da escola Tulipa. Trata-se da entrada em sala da merendeira da escola, cerca de 40 minutos após o horário definido para a merenda, com uma cesta cheia de bananas. Ela vai de mesa em mesa distribuindo uma fruta para cada aluno. Segundo explicação da merendeira, muitas bananas tinham sobrado e, para não estragar, ela resolveu ir de sala em sala distribuindo-as para os alunos, professores e outros profissionais da escola. Esta pode ter sido uma cena incomum, mas mostra que a decisão de interromper as aulas, não é uma prerrogativa pedagógica da direção, da coordenação pedagógica ou da professora.

Há também o desperdício diário de alguns minutos no final das aulas, quando as professoras encerram as atividades didático-pedagógicas antes do horário regular, justificando que não há mais tempo para iniciar outra atividade e, 
por isso, pedem aos alunos para que guardem seus materiais e para aguardarem o sinal tocar para ir embora.

\section{PARTICIPAÇÃO E ENVOLVIMENTO DOS PAIS NAS ATIVIDADES ESCOLARES DOS FILHOS}

O relacionamento da escola com a família é apontado como um dos 11 fatores elencados por Sammons (apud BROOKE e SOARES, 2008) das escolas eficazes. As escolas que promovem eventos de forma a chamar as famílias a se engajarem nas atividades escolares dos filhos contribuem para o bom desempenho dos alunos.

Nesse estudo, esta categoria de análise foi investigada por meio das entrevistas realizadas com os agentes educacionais.

Todos os profissionais entrevistados afirmaram que um dos maiores desafios enfrentados pelas escolas é a participação da família na vida escolar dos filhos. Quando a escola promove eventos e reuniões, os responsáveis participam. Entretanto, na fala dos entrevistados, essa participação poderia ser mais efetiva. A diretora da escola Tulipa explica que deveria existir um engajamento maior dos pais nas atividades escolares que os alunos realizam em casa. Segundo ela, "Se as famílias em casa ajudassem mais no aprendizado do aluno, acho que a nossa meta seria melhor." Para a pedagoga do turno da manhã, as famílias não compreenderiam bem para que serve a escola, por que a escola seria importante. A falta de significado e de importância da escola para essas famílias afetaria, na visão da pedagoga, o desempenho dos estudantes. Segundo esta profissional, as famílias olham para a escola como um depósito, em que elas deixam os filhos para poderem trabalhar e, também, para ganharem os benefícios do governo. Apesar disso, ela afirma que as famílias são participativas e sempre comparecem às reuniões e plantões pedagógicos - reuniões individuais com os pais para informar sobre o desenvolvimento do aprendizado dos filhos. Nos dias de plantão pedagógico, os alunos são dispensados e os professores se dedicam a atender aos pais.

Na escola Rosa, os pais não são participativos. Segundo a pedagoga, dos 160 alunos, apenas 20 ou 30 pais frequentam as reuniões. Afirma que os alunos são "órfãos" na medida em que eles precisam "resolver sozinhos seus próprios 
problemas" e que a ausência dos pais na vida escolar dos alunos é a "principal motivo que dificulta o aprendizado". A escola também realiza plantões pedagógicos e a maioria dos pais participa.

$\mathrm{Na}$ escola Girassol, a participação dos pais é mais efetiva. Todas as professoras, a pedagoga e a diretora disseram que as famílias participam da vida escolar dos filhos em casa, monitorando o material escolar e acompanhando a realização das tarefas e participando das reuniões e eventos na escola. Essa participação dos pais na vida escolar dos filhos foi percebida pelo aspecto apresentado pelos materiais escolares que estavam muito bem conservados mesmo estando no final do ano, e, ainda, pela mobilização familiar no sentido de enviar materiais e lanches para a festinha de confraternização de fim de ano.

$\mathrm{Na}$ escola Lírio, tanto as pedagogas quanto a diretora afirmaram que os pais participam das reuniões e dos eventos escolares, mas que falta cobrança e acompanhamento da vida escolar dos filhos em casa. Segundo a pedagoga da manhã, os pais justificam a ausência de acompanhamento na realização das tarefas escolares em casa por falta de tempo ou porque eles não sabem ler e escrever. 


\section{CONSIDERAÇÕES FINAIS}

À luz dos conceitos de igualdade de oportunidades, de tratamento e de conhecimento (CRAHAY, 2002), este estudo procurou mapear as desigualdades educacionais nos níveis macro, meso e micro analítico.

No nível macro, os resultados mais geraisda Educação Básica ratificam a falta de oportunidades e a desigualdade de acesso ao ensino médio, segundo diferentes grupos sociais. Além disso, mostram a desigualdade de aprendizado existente na alfabetização e no fluxo escolar ao longo do primeiro segmento do ensino fundamental entre as cinco regiões brasileiras. Nas regiões Sul, Sudeste e Centro-oeste, os dados são significativamente melhores que nas regiões Norte e Nordeste, evidenciando a desigualdade brasileira na oferta de uma escola de qualidade.

No nível meso, a pesquisa se voltou para a desigualdade de conhecimento dos alunos participantes do PAEBES-Alfa no período de 2012 a 2014, correspondente ao ciclo de alfabetização, observando o percentual de acerto dos itens e sua variação nos testes cognitivos de leitura, no $1^{\circ}$ e $3^{\circ}$ anos do ensino fundamental. Um dos resultados mais importante da pesquisa se coloca na perspectiva da equidade e aponta para o processo de homogeneização dos resultados escolares entre turmas e escolas. No $1^{\circ}$ ano, a variação do percentual de acerto entre as turmas é maior do que no $3^{\circ}$ ano. Isso significa que, no início da alfabetização, há mais desigualdade de conhecimento do que no final, uma vez que, ao longo desse período, as turmas conseguem diminuir a variação do percentual de acerto e, portanto, promover uma maior igualdade de conhecimento.

Entretanto, a análise do percentual de acerto segundo o grau de dificuldade do item mostra que poucos alunos conseguem acertar os itens difíceis de leitura e que, neste caso, é ainda mais significativa a variação do acerto entre as turmas. Nesse sentido, o segundo resultado importante da pesquisa evidencia que as habilidades mais elementares referentes à aprendizagem da leitura são adquiridas por praticamente todos os alunos, mas apenas alguns alunos se apropriam das habilidades mais complexas avaliadas pelo PAEBES-Alfa.

Quando analisamos o $1^{\circ}$ ano, verificamos que há um baixo percentual de acerto nas turmas de alto e baixo desempenho de itens que medem habilidades 
mais complexas. No entanto, este resultado é apenas uma medida das habilidades com que os começaram sua escolaridade quando foram avaliados no início do $1^{\circ}$ ano a ser usada na comparação com o $3^{\circ}$ ano.

No $3^{\circ}$ ano, os resultados mais importantes mostram que alguns itens difíceis apresentam significativos percentuais de acerto nas turmas de alto e baixo desempenho, indicando que, possivelmente, a habilidade avaliada está consolidada em ambos os grupos. Mostram, também, que há outros itens difíceis que, no entanto, obtiveram um percentual de acerto bem menor nos dois grupos de turmas, indiciando que certas habilidades complexas não teriam sido ensinadas nas escolas. Por meio dessa metodologia, foi possível observar, então, quais são os aspectos curriculares que, do ponto de vista da eficácia e da equidade escolar, se apresentam como um desafio para as redes públicas do Estado de Espírito Santo seja porque nivelam por baixo a alfabetização dos alunos, seja porque contribuem para as desigualdades de conhecimento entre as turmas e escolas.

No nível micro, foi investigada qualitativamente em quatro escolas a desigualdade de resultados e de práticas pedagógicas referenciadas pela literatura como eficazes.

As quatro escolas investigadas possuem características sociais similares, possuem índice socioeconômico semelhante, sendo que uma escola situa-se em local de alta vunerabilidade social, com alto índice de criminalidade. Todas as escolas possuem alunos beneficiários do Bolsa Família e recebem projetos do Programa Mais Educação.

Nas turmas das escolas Girassol e Lírio (município de Serra) a desigualdade dos resultados é pequena. Nessas escolas, as turmas começam o ciclo de alfabetização com nível de desempenho insatisfatório e terminam com um nível adequado de aprendizagem. São essas escolas que conseguem agregar valor ao aprendizado dos alunos ao mesmo tempo em que conseguem diminuir a variação do desempenho entre as turmas, tornando os resultados escolares mais homogêneos. Algumas caracetrísticas observadas podem ajudar a explicar esses resultados, como por exemplo, o comprometimento com o aprendizado dos alunos, a boa relação das professoras com as pedagogas e demais colegas e o relacionamento da escola com a família. 
Por outro lado, os resultados longitudinais das turmas das escolas Tulipa e Rosa (município de Cariacica) mostram oscilações no desempenho, de forma tal que, ao final do $3^{\circ}$ ano, algumas turmas não conseguem alcançar um nível de aprendizagem adequado. Há uma maior heterogeneidade dos resultados das turmas dessas escolas, revelando maior desigualdade na aquisição de conhecimentos referentes à alfabetização.

Enquanto as escolas do município de Serra conseguem fazer com que os resultados sejam mais homogêneos no final do $3^{\circ}$ ano, nas escolas do município de Cariacica esses resultados são mais heterogêneos. As análises aqui realizadas permitem apontar que, nas turmas das duas escolas pesquisadas nesse município, os resultados escolares são mais homogêneos do que nas turmas das escolas do município de Cariacica. Isto faz com que as escolas de Serra sejam mais eficazes pois, a despeito da composição social da escola, agregam valor ao aprendizado dos alunos ao mesmo tempo em que conseguem promover um aprendizado mais igualitário entre as turmas.

Os resultados deste estudo evidenciam a importância de se contar com dados longitudinais dos anos iniciais do ensino fundamental, pois os mesmos permitem revelar que as desigualdades entre as escolas e turmas se fazem presentes desde o início do ensino fundamental e vão diminuindo ao longo do ciclo de alfabetização. Esses dados também permitiram revelar a incapacidade da maioria das escolas para ensinar, de forma eficaz, importantes habilidades relacionadas com a alfabetização, nivelando por baixo o desempenho da maioria de seus alunos.

Considerando o conjunto dos resultados da pesquisa, podemos concluir que, embora estes resultados apontem para uma redução das desigualdades entre as turmas de alto e baixo desempenho, a falta de acesso pelos alunos a habilidades essenciais durante o processo de alfabetização certamente contribui para a manutenção do quadro de desigualdades do sistema de ensino como um todo. 


\section{Referências Bibliográficas}

ALVES, F. Qualidade na Educação Fundamental Pública nas capitais brasileiras. Tendências, contextos e desafios. Rio de Janeiro:Editora Argvmentvm. PUC-Rio, 2009.

ALVES, M. T. G.; FRANCO, C. A pesquisa em eficácia escolar no Brasil: evidências sobre o efeito das escolas e fatores associados à eficácia escolar. In: BROOKE, N.; SOARES, J.F. (Orgs.) Pesquisa em eficácia escolar: origem e trajetórias. Belo Horizonte: Editora UFMG, 2008.

ALVES, M.T.G; SOARES, J.F. Efeito-escola e estratificação escolar: o impacto da composição de turmas por nível de habilidade dos alunos. In: Educação em Revista. Belo Horizonte, v. 45. Pp. 25-58, 2007.

ALVES, M.T.G.; SOARES, J.F. O efeito das escolas no aprendizado dos alunos: um estudo com dados longitudinais no Ensino Fundamenyal. In: Educação e Pesquisa. São Paulo, v. 34, n.3, pp. 527-544, 2008.

ARISTÓTELES. Ética a Nicômaco. Trad.Torrieri Guimarães. São Paulo. Martin Claret, 2015. Coleção A obra-prima de cada autor.

BARBOSA, M.L. DE O. School quality and social inequalities in achievement: a research note. In: RUZICKA, BALLANTINE and RUIZ (orgs.) Key contexts for education and democracy in globalising societies. Proceedings of Education, Participation, Globalization Conference, Prague, 2004.

BARBOSA, M.L.O. As relações entre educação e raça no Brasil: um objeto em construção. In: SOARES, S. et all (org.). Os mecanismos de discriminação racial nas escolas brasileiras. Rio de Janeiro. IPEA, 2005.

BARBOSA, M.L.O. Desigualdade e desempenho: uma introdução à sociologia brasileira. Belo Horizonte. Editora Fino Traço, 2011.

BERNARDO, E. Composição social e cognitiva de turmas e desempenho em Leitura e Matemática: como evoluem as desigualdades educacionais?, 2008, 202fls. Tese (Doutorado em Educação) - Pontifícia Univeridade Católica do Rio de Janeiro, 2008.

BRASIL. Constituição (1988). Constituição da República Federativa do Brasil. Brasília, DF: Senado Federal: centro Gráfico, 1988. 292 p.

Nota explicativa - Avaliação Nacional da Alfabetização - ANA

2013. MEC, Instituto Nacional da Pesquisas Educacionais Anísio Teixeira, Brasília, 2014.

BRESSOUX, Pascoal. Les recherches sur les effets-écoleset les effets-maîtres. RevueFrançaise de Pédagogie, n.108, julho-agosto-setembro, 1994. 
BROOKE, N.; BONAMINO, A; MACHADO SOARES, T. As inconsistências na aprendizagem de Leitura e Matemática nos anos iniciais do Ensino Fundamental. Projeto de Pesquisa submetido à avaliação da CAPES, Edital no 038/2010/CAPES/INEP, agosto de 2010.

BROOKE, N.; BONAMINO, A. (Orgs.) GERES 2005: razões e resultados de uma pesquisa longitudinal sobre eficácia escolar. Rio de Janeiro: Walprint, 2011.

BROOKE, N; SOARES, J.F. Pesquisa em eficácia escolar: origem e trajetórias. Belo Horizonte. Editora UFMG, 2008.

BOURDIEU, P.; PASSERON, J. Los estudiantes y la cultura. $2^{\text {a }}$. ed. Barceloma: Labor, 1969.

CAMPOS, M. M. Educação infantil: o debate e a pesquisa. Cadernos de Pesquisa, no. 101, p. 113-127, jul. 1997.

CAMPOS, Maria Malta. A contribuição da educação infantil de qualidade e seus impactos no início do ensino fundamental. Educação e Pesquisa, vol.37, ano 1, São Paulo, jan,/abr. 2011.

CARVALHO, M. P.Sucesso e fracasso escolar: uma questão de gênero. Educação e Pesquisa, São Paulo, v. 29, n. 1, p.185-193, jun. 2003.

O fracasso escolar de meninos e meninas: articulações entre gênero e cor/raça. Cadernos Pagu, Campinas, n. 22, p. 247-290, jun. 2004.

COSTA RIBEIRO, C.A. Desigualdade de oportunidades no Brasil. Belo Horizonte. Editora Argvmentvm, 2009.

CORREA, E. Efeito da repetência nos anos iniciais do Ensino Fundamental: um estudo longitudinal a partir do Geres, 2013, 122 fls. Dissertação (Mestrado em Educação) - Pontifícia Universidade Católica do Rio de Janeiro, Rio de Janeiro, 2013.

CRAHAY, M. Poderá a escola ser justa e eficaz? Da igualdade de oportunidades à igualdade de conhecimentos. Tradução Vasco Farinha. Lisboa: Instituto Piaget, 2002.

CRAHAY, M. L'école peut-elle être juste et efficace? De l'égalité des chances à l'égalité des acquis. Belgique: DeBpeck, 2013.

CRAHAY, M.; BAYE, A. Existem escolas justas e eficazes? Esboço de resposta baseado no PISA 2009. In: Cadernos de Pesquisa. São Paulo, vol. 43, n.150, pp. 858-883, 2014. 
CRAHAY, M. É possível tirar conclusões sobre os efeitos da repetência? In: Cadernos de Pesquisa. São Paulo, vol. 36, n.127, pp.223-246, 2006.

CARNOY, M. A vantagem acadêmica de Cuba: porque seus alunos vão melhor na escola. São Paulo: Ediouro e Fundação Lemann, 2009.

DUBET, F. O que é uma escola justa? In: Cadernos de Pesquisa. São Paulo, vol. 34 , n. 123 , pp. 539-555, 2004a.

DUBET, F. L'école des chances: Qu'est-ce qu'une école juste? Paris, 2004b.

DUBET, F.; DURU-BELLAT, M.; VÉRÉTOUT, A. Les sociétes et leur école: emprese du diplôme et cohésin sociale. Paris, 2010.

DURU-BELLAT, M. Les apprentissages des élèves dans leus context: les effets de la composition de l'environnement scolaire. In : Carrefours de l'éducation. Vol. 2, no. 16, pp.182-206, 2003.

FALCÃO FILHO, J.L.M. A qualidade na escola. In: Revista Ensaio: avaliação e políticas públicas em educação. Rio de Janeiro, vol. 5, n.16, pp.313-326, 1997.

FORQUIN, J.C. (Org.) Sociologia da Educação: dez anos de pesquisa. Petrópolis. Ed. Vozes, 1995.

FRANCO, C. Ciclos e Letramento na fase inicial do ensino fundamental. In: Revista Brasileira de Educação, n. 25. Rio de Janeiro, 2004

GOLDSTEIN, H. Modelos de realidade: novas abordagens para a compreensão de processos educacionais. In: FRANCO, C. (org.) Avaliação, Ciclos e Promoção na Educação.Porto Alegre: Artmed Editora, pp. 84-99, 2001.

LOUKAS, A. What Is School Climate? High-quality school climate is advantageous for all students and may be particularly beneficial for at-risk students. Leadership Compass, Virginia, Estados Unidos, vol. 5, no. 1, out. 2007.

MARQUES, C de A; AGUIAR, R.R; CAMPOS, M.O.C. Programa alfabetização na idade certa: concepções, primeiros resultados e perspectivas.Estudos em Avaliação Educacional, vol. 20, n. 43, pp. 275-291, São Paulo, 2009.

MARTINIC, C.; PRADO, M. (2003). La investigación sobre eficacia escolar en Chile. In: MURILLO, C. La investigación sobre eficacia escolar en Iberoamérica. Revisión interna sobre Estado del Arte. Convenio Andrés Bello, Ministerio de la Educación, Cultura y Deporte. España y CIDE. Chile.

MAYER, D. P. Measuring Instructional Practice: can policymakers trust surveydata? Educational Evaluation and Policy Analysis. Vol. 21, n. 1, 1999. 
MELLO, G.N. Cidadania e competitividade: desafios educacionais do terceiro milêncio. São Paulo, Cortez, 1994.

MORTIMORE, P. et alii (1991). Scholl matters. The Junior Years. Somerset. Open Books.

MURILLO, F.J.T. Una panorámica de la investigación iberoamericana sobre eficacia escolar. In: Revista Electrónica Iberoamericana sobre Calidad, Eficacia y Cambio en Educación. Vol. 01, n.1, pp.1-14, 2003

OCDE. "Quando os estudantes repetem um ano ou são transferidos da escola: o que isso significa para os sistemas de educação?" In: Pisa em Foco, n. ${ }^{\circ} 6$, julho de 2011. Disponível em: http://www.pisa.oecd.org

OLIVEIRA, R. P.; BAUER, A.; FERREIRA, M. P.; MINUCI, E.G.; LISAUSKA, F.; ZIMBARG, R.; CASSETTARI, N.; CARVALHO, M.; GALVÃO, F. V. Análise das desigualdades intraescolares no Brasil. In: Estudos e Pesquisas Educacionais. São Paulo. Fundação Victor Civita, no. 14, 2013.

OLIVEIRA, R. P. Da universalização do ensino fundamental ao desafio da qualidade: uma análise histórica. In: Educação e Sociedade. Campinas, vol. 28, n. 100, p.661-690, 2007.

PEDROSA, F. Clima acadêmico e promoção da aprendizagem nos Anos Iniciais do Ensino Fundamental, 2007, 117 fls, Dissertação (Mestrado em Educação) - Pontifícia Univeridade Católica do Rio de Janeiro, 2007.

POLON, T. Identificação dos perfis de liderança e características relacionadas à gestão pedagógica efcaz nas escolas participantes do Projeto Geres - Estudo Longitudinal Geração Escolar - Pólo Rio de Janeiro, 2009, 309 fls. Tese (Doutorado em Educação) - Pontifícia Univeridade Católica do Rio de Janeiro, 2009.

RAUDENBUSH, S.W. and BRYK, A.S. Hierarchical Linear Models(SecondEdition).Thousand Oaks: SagePublications, 2002.

RAWLS, J. La justice comme équité: une réformulation de Théorie de la justice. France, 2008.

REYNOLDS, D.; CREEMERS, B. (eds.). School Effectiveness and Improvement. RION, Institute of Educational Research. London.

RIBEIRO, V. Justiça na escola e regulação institucional em redes de ensino do estado de São Paulo, 2012, 489 fls. Tese (Doutorado em Educação) Universidade de São Paulo, São Paulo, 2012.

ROCHA, G.; MARTINS, R.F. Avaliação da escrita externa à escola nos três primeiros anos do ensino fundamental: um subsídio para a prática docente?Disponível

em: 
www.anpae.org.br/ideroamericano2012/Trabalhos/GladysRocha res int GT1.pdf. Acesso em 10/04/2012

SAMMONS, P.; HILLMAN, S. and MORTIMORE, P. (1995). Key Characteristics of Effective Schools. A Review of School Effectiveness Research. London : OFTED.

SEGUEL, X. et alii. (1999). Pauta de observación de prácticas docentes. Estudio de sus características psicométricas. Centro de Estudios de Desarrollo y Estímulo Psicosocial. Santiago de Chile. Chile.

SHEERENS, J. and BOSKER, R. J. (1997). The foundations of Educational Effectiveness. Oxford. Elsevier Science Ltda.

SILVA, N.V. Expansão escolar e estratificação educacional no Brasil. In: HASENBALG, C. e SILVA, N.V. Origens e destinos. Rio de Janeiro. Editora Topbooks, 2003.

SLAVIN, R. (1996). Salas de aula efectivas, escuelas efectivas. Plataforma de investigación para una Reforma Educativa en América Latina. Documento traducido por PREAL, Santiago de Chile. Chile.

SOARES, J.F.; ALVES, M. T.G.. Desigualdades raciais no sistema brasileiro de educação básica. Educação e Pesquisa, São Paulo, v. 29, n. 1, p. 147-165, 2003.

SOARES, J.F. Escola eficaz: um estudo de caso em três escolas da rede pública de ensino do Estado de Minas Gerais. Belo Horizonte: UFMG: Fundação Ford, 2002.

Measuring cognitive achievement gaps and inequalities: The case of Brazil. International Journal of Educational Research, 45(3):176-187, 2006.

Índice de Desenvolvimento da Educação de São Paulo - IDESP: bases metodológicas. In: São Paulo em Perspectiva, São Paulo, v. 23, n. 1, p. 29 41, jan./jun. 2009.

SOARES, M. B. Letramento: um tema em três gêneros. Belo Horizonte: Autêntica, 1999.

Alfabetização: a ressignificação do conceito. Alfabetização e Cidadania. Revista de Educação de Jovens e Adultos. RaaB, n. 16, julho 2003.

SOARES, J.F; ALVES, M.T.G. Contexto escolar e indicadores educacionais: condições desiguais para a efetivação de uma política de avaliação educacional. In: Educação e Pesquisa, São Paulo, v. 39, n. 1, p. 177-194, jan./mar. 2013. 
SOARES, J.F.; ANDRADE, R.. Nível sócio-econômico, qualidade e equidade das escolas de Belo Horizonte. Ensaio: Avaliação de Políticas Públicas Educacionais, 14(50):107-126, 2006.

SOARES, J. F; CANDIAN, J. F. O efeito da escola básica brasileira: as evidências do PISA e do SAEB. Revista Contemporânea de Educação, v. 2, n. 4, p. 1-12, 2007.

SOARES, J.F.; FONSECA, I.C.; ALVARES, R.P.; GUIMARÃES, R.R.M. Exclusao intraescolar nas escolas públicas brasileiras: um estudo com dados da Prova Brasil 2005, 2007 e 2009. Debates ED, v.4, pp.1-77, 2012.

SOARES, J.F.; MAROTTA, L. Desigualdade no sistema de ensino fundamental brasileiro.In Giambiagi, F., Henriques, R., Pessôa, S., \& Veloso, F., editors, Educação Básica no Brasil, pages 73-91. Elsevier, Rio de Janeiro, 2008 .

TODOS PELA EDUCAÇÃO. Anuário Brasileiro da Educação Básica 2012. Ed. Moderna. 2012. Disponível em: http://www.gruposantillana.com.br/newsletter/ Fundacao/Anuario_Educacao.pdf

- Relatório de olho nas metas $2011-4^{\circ}$ Relatório de Monitoramento, Todos pela Educação, 2012. Disponível em: http://todospelaeducacao.org.br/arquivos/biblioteca/de_olho_nas_metas_2011_tpe .pdf

TOLEDO, J. A escrita na avaliação da alfabetização em larga escala, 2013, 135 fls. Tese (Doutorado em Educação) - Pontifícia Univeridade Católica do Rio de Janeiro, 2013.

VALLE, I.R. Justiça na escola: das desigualdades justas à igualdade sem adjetivos!. In: VALLE, I.R., SILVA, V.L.G e DAROS, M.D (Orgs.). Educação escolar e justiça social. Florianópolis: Núcleo de Publicações do Centro de Ciências da Educação/ UFSC, v.1, p.19-48, 2010.

WALTENBERG, F. Análise economica de sistemas educativos. Uma resenha crítica da literatura e uma avaliação empírica da iniquidade do sistema educativo brasileiro, 2002, 159fls. Dissertação (Mestrado em Economia) Universidade de São Paulo, São Paulo, 2002.

WALTENBERG, F. Quatre grandes écoles pour penser la justice dans le champ de l'éducation. In: DUPRIEZ, V. ORIANNE, J.F., VERHOEVEN, M. (Org). De l'école au marché du travail, l'égalité des chances en question. Bern: Peter Lang/INRP, p. 25-52, 2008.

WILLMS, J.D. Monitoring school performance - a guide for educators. Londres: The FalmerPress, 1992. 
XAVIER, F. P. e ALVES, M. T. G. A composição social importa para os efeitos das escolas no ensino fundamental?. Est. Aval. Educ., São Paulo, v. 26, n. 61, p. 216-243, jan./abr. 2015. 


\section{ANEXOS}

\section{ANEXO 1}

Matriz de referência de Língua Portuguesa (leitura e escrita) do PAEBES-Alfa

\begin{tabular}{|c|c|c|c|c|c|c|}
\hline \multicolumn{7}{|c|}{ MATRIZ DE REFERÊNCIA DE LÍNGUA PORTUGUESA - PAEBES ALFA $1^{\circ}$ ao $3^{\circ}$ ano do Ensino Fundamental } \\
\hline Tópicos & Competências & Descritores & Níveis de Complexidade & $1^{\circ}$ & $\begin{array}{c}2^{\circ} \\
\mathrm{ANO}\end{array}$ & $\begin{array}{l}3^{\circ} \\
\mathrm{ANO}\end{array}$ \\
\hline \multirow{5}{*}{$\begin{array}{c}\text { T1- } \\
\text { Reconhecimento } \\
\text { de convenções } \\
\text { do sistema } \\
\text { alfabético. }\end{array}$} & \multirow{5}{*}{$\begin{array}{l}\text { C1. } \\
\text { Identificação de } \\
\text { letras do } \\
\text { alfabeto. }\end{array}$} & $\begin{array}{l}\text { D01 - Reconhecer } \\
\text { especificidades da } \\
\text { linguagem escrita. }\end{array}$ & N1 - Distinguir entre desenho e escrita. & $X$ & & \\
\hline & & \multirow{3}{*}{$\begin{array}{l}\text { D02 - Identificar } \\
\text { letras do alfabeto. }\end{array}$} & $\begin{array}{l}\text { N1 - Identificar uma letra entre várias } \\
\text { letras apresentadas isoladamente. }\end{array}$ & $X$ & & \\
\hline & & & $\begin{array}{l}\text { N2 - Identificar uma, duas ou mais letras } \\
\text { no contexto de uma palavra. }\end{array}$ & $\mathrm{X}$ & $\mathrm{X}$ & \\
\hline & & & $\begin{array}{l}\text { N3 - Identificar, entre várias sequências, } \\
\text { uma sequência de letras determinada. }\end{array}$ & $\mathrm{X}$ & $\mathrm{X}$ & $\mathrm{X}$ \\
\hline & & $\begin{array}{l}\text { D03 - Diferenciar } \\
\text { letras de outros sinais } \\
\text { gráficos, como os } \\
\text { números, sinais de }\end{array}$ & $\begin{array}{l}\text { N1 - Identificar, em sequências com } \\
\text { letras números e outros símbolos, a } \\
\text { sequência que só tem letras ou que tem } \\
\text { letras e números. }\end{array}$ & $X$ & & \\
\hline
\end{tabular}




\begin{tabular}{|c|c|c|c|c|c|}
\hline & \multirow[t]{2}{*}{$\begin{array}{l}\text { pontuação ou de } \\
\text { outros sistemas de } \\
\text { representação. }\end{array}$} & $\begin{array}{l}\text { N2 - Identificar, em textos que circulam } \\
\text { socialmente (placas de trânsito, } \\
\text { logomarcas, envelope, lista, cartaz, etc.) } \\
\text { aquele que apresenta somente letras ou } \\
\text { que tem letras e números. }\end{array}$ & $X$ & $X$ & $X$ \\
\hline & & $\begin{array}{l}\text { N3 - Identificar, em textos que circulam } \\
\text { socialmente (placas de trânsito, } \\
\text { logomarcas, envelope, lista, cartaz, etc.) } \\
\text { aquele que apresenta letras e números. }\end{array}$ & $X$ & $X$ & $X$ \\
\hline & \multirow{3}{*}{$\begin{array}{l}\text { D04 - Distinguir, } \\
\text { como leitor, diferentes } \\
\text { tipos de letras. }\end{array}$} & $\begin{array}{l}\text { N1 - Distinguir diferentes formas de } \\
\text { traçar uma mesma letra. }\end{array}$ & $X$ & $X$ & $X$ \\
\hline & & $\begin{array}{l}\text { N2 - Identificar uma palavra escrita com } \\
\text { letras diferentes. }\end{array}$ & $X$ & $X$ & $X$ \\
\hline & & $\begin{array}{l}\text { N3 - Identificar duas ou três palavras } \\
\text { escritas com letras diferentes. }\end{array}$ & & & $X$ \\
\hline \multirow[t]{2}{*}{$\begin{array}{l}\mathrm{C} 2 . \text { Uso } \\
\text { adequado da } \\
\text { página. }\end{array}$} & \multirow[t]{2}{*}{$\begin{array}{l}\text { D05 - Reconhecer as } \\
\text { direções e o } \\
\text { alinhamento da escrita } \\
\text { da língua portuguesa. }\end{array}$} & $\begin{array}{l}\text { N1 - Identificar a direção da escrita (da } \\
\text { esquerda para a direita, de cima para } \\
\text { baixo), na leitura de pequenos textos, } \\
\text { identificando a primeira ou a última } \\
\text { palavra deles. }\end{array}$ & $X$ & $X$ & $X$ \\
\hline & & $\begin{array}{l}\text { N2 - Registrar frases ou pequenos } \\
\text { textos, tendo em vista sua ordem de } \\
\text { alinhamento e direcionamento na página. }\end{array}$ & $X$ & $X$ & $X$ \\
\hline
\end{tabular}




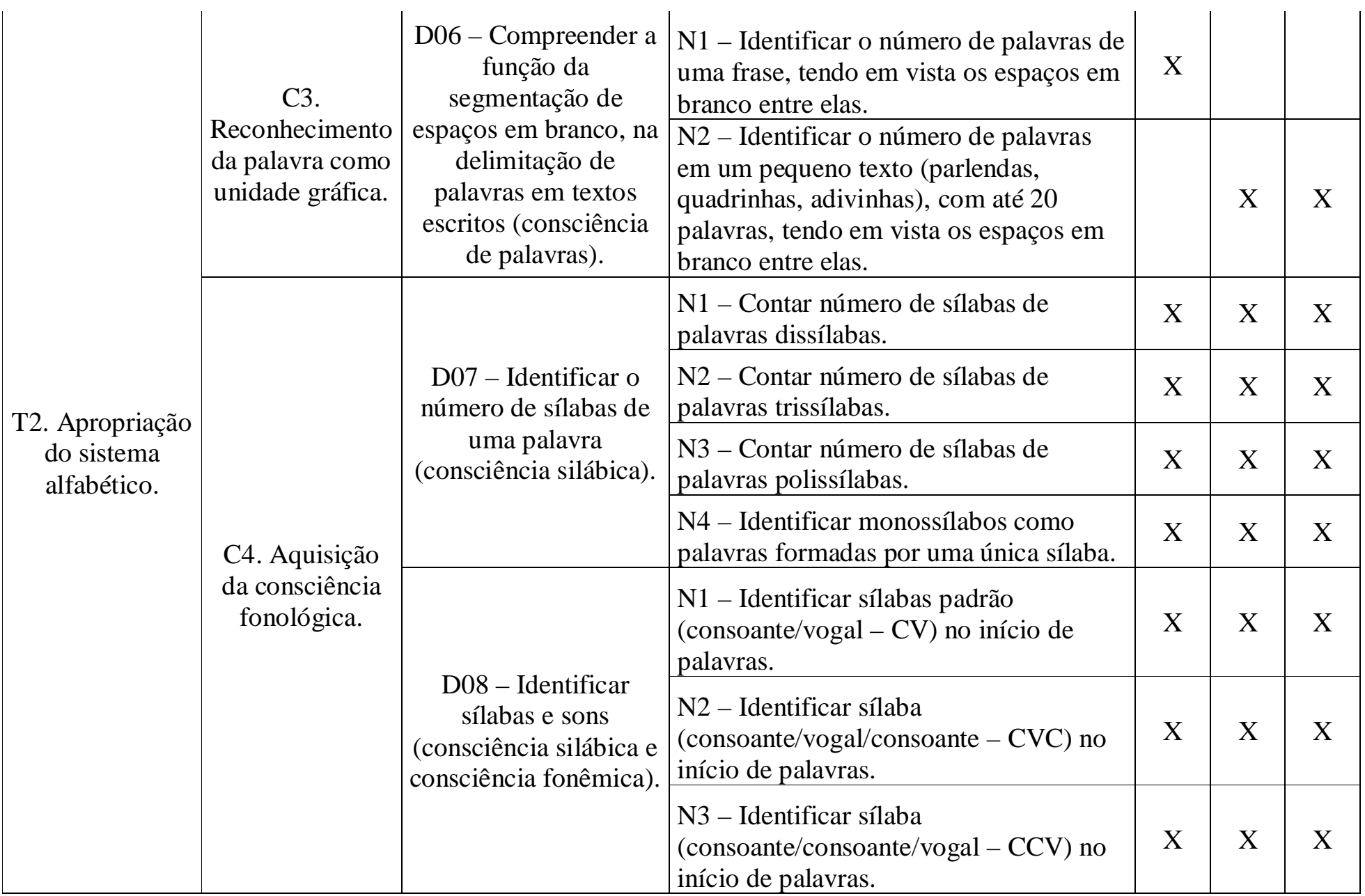




\begin{tabular}{|c|c|c|c|c|c|}
\hline & \multirow{10}{*}{$\begin{array}{l}\text { D09 - Identificar } \\
\text { relações } \\
\text { fonema/grafema, } \\
\text { som/letra (consciência } \\
\text { fonêmica). }\end{array}$} & $\begin{array}{l}\text { N4 - Identificar sílaba (vogal/consoante/ } \\
\text { - VC) no início de palavras. }\end{array}$ & $X$ & $X$ & $X$ \\
\hline & & $\begin{array}{l}\text { N5 - Identificar sílaba formada apenas } \\
\text { por uma vogal - V no início de palavras. }\end{array}$ & $X$ & $X$ & $X$ \\
\hline & & $\begin{array}{l}\text { N6 - Identificar sílaba formada por } \\
\text { dígrafo e/ou ditongo no início de } \\
\text { palavras. }\end{array}$ & $\mathrm{X}$ & $X$ & $X$ \\
\hline & & $\begin{array}{l}\text { N7 - Identificar palavras que terminam } \\
\text { com a mesma sílaba. }\end{array}$ & $X$ & $X$ & $X$ \\
\hline & & $\begin{array}{l}\text { N8 - Identificar sílaba CV no meio de } \\
\text { palavras trissílabas. }\end{array}$ & $X$ & $X$ & $X$ \\
\hline & & $\begin{array}{l}\text { N9 - Identificar o valor sonoro de uma } \\
\text { sílaba (inicial, medial ou final) em que } \\
\text { não haja correspondência biunívoca } \\
\text { entre o fonema e o grafema (o fonema } \\
\text { /s/,e as letras, ss,c,ç, etc., por exemplo). }\end{array}$ & $X$ & $X$ & $X$ \\
\hline & & $\begin{array}{l}\text { N1 - Identificar palavras iniciadas por } \\
\text { um mesmo fonema. }\end{array}$ & $X$ & $X$ & $X$ \\
\hline & & $\begin{array}{l}\text { N2 - Identificar uma palavra que se } \\
\text { diferencia de outras por apenas um } \\
\text { fonema (som). }\end{array}$ & & $X$ & $X$ \\
\hline \multirow{2}{*}{$\begin{array}{l}\text { C5. Leitura de } \\
\text { palavras, frases } \\
\text { e pequenos } \\
\text { textos. }\end{array}$} & & $\begin{array}{l}\text { N1 - Ler palavra iniciada por sílaba } \\
\text { padrão Consoante/Vogal - CV. }\end{array}$ & $X$ & $X$ & $X$ \\
\hline & & $\begin{array}{l}\text { N2 - Ler palavra iniciada por sílaba } \\
\text { Consoante/Vogal/Consoante - CVC. }\end{array}$ & $X$ & $X$ & $X$ \\
\hline
\end{tabular}




\begin{tabular}{|c|c|c|c|c|c|c|}
\hline & & & $\begin{array}{l}\text { N3 - Ler palavra iniciada por sílaba } \\
\text { Consoante/Consoante/Vogal - CCV. }\end{array}$ & $X$ & $X$ & X \\
\hline & & & $\begin{array}{l}\text { N4 - Ler palavra iniciada por sílaba } \\
\text { Vogal/ Consoante - VC }\end{array}$ & $X$ & $X$ & $X$ \\
\hline & & & $\begin{array}{l}\text { N5 - Ler palavra iniciada por sílaba } \\
\text { constituída de apenas uma Vogal - V. }\end{array}$ & $X$ & $X$ & $\mathrm{X}$ \\
\hline & & & $\begin{array}{l}\text { N6 - Ler palavras com dígrafo e/ou } \\
\text { ditongo em qualquer posição, inclusive } \\
\text { em monossílabos. }\end{array}$ & $X$ & $X$ & $\mathrm{X}$ \\
\hline & & & $\begin{array}{l}\text { N1 - Localizar uma informação explícita } \\
\text { em frase curta de padrão sintático } \\
\text { simples (Sujeito/Verbo/Objeto). }\end{array}$ & $X$ & $X$ & $\mathrm{X}$ \\
\hline & & $\begin{array}{l}\text { D11 - Ler frases e } \\
\text { pequenos textos, } \\
\text { localizando }\end{array}$ & $\begin{array}{l}\text { N2 - Localizar uma informação explícita } \\
\text { em frase longa de padrão sintático (e } \\
\text { silábico) complexo. }\end{array}$ & & & $X$ \\
\hline & & $\begin{array}{l}\text { informações explícitas } \\
\text { contidas neles. }\end{array}$ & $\begin{array}{l}\text { N3 - Localizar uma informação explícita } \\
\text { em textos curtos (de mais ou menos } 6 \\
\text { linhas) de gêneros diversos (bilhete, } \\
\text { cartaz, tirinhas, quadrinhos, receita, } \\
\text { notícia, instrução, entrevistas, } \\
\text { anúncios...) }\end{array}$ & $X$ & $X$ & $X$ \\
\hline $\begin{array}{c}\text { T3 - Usos } \\
\text { sociais da leitura } \\
\text { e da escrita. }\end{array}$ & $\begin{array}{l}\text { C6. Implicações } \\
\text { do suporte e do } \\
\text { gênero na } \\
\text { compreensão de } \\
\text { textos. }\end{array}$ & $\begin{array}{l}\text { D12 - Reconhecer o } \\
\text { local de inserção de } \\
\text { determinada palavra } \\
\text { numa sequência em } \\
\text { ordem alfabética }\end{array}$ & $\begin{array}{l}\text { N1- Reconhecer o local de inserção de } \\
\text { determinada letra/palavra, tendo em } \\
\text { vista a sequência alfabética, } \\
\text { considerando até a segunda letra das } \\
\text { palavras apresentadas. }\end{array}$ & $X$ & $X$ & $X$ \\
\hline
\end{tabular}




\begin{tabular}{|c|c|c|c|c|c|c|}
\hline & & & $\begin{array}{l}\text { N2 - Reconhecer o local de inserção de } \\
\text { determinada letra/palavra, tendo em } \\
\text { vista a sequência alfabética, } \\
\text { considerando qualquer posição da letra } \\
\text { nas palavras apresentadas. }\end{array}$ & & $\mathrm{X}$ & $\mathrm{X}$ \\
\hline & & $\begin{array}{l}\text { D13 - Identificar } \\
\text { gêneros textuais } \\
\text { diversos. }\end{array}$ & $\begin{array}{l}\text { N1 - Identificar o gênero de textos } \\
\text { diversos. }\end{array}$ & $X$ & $X$ & $\mathrm{X}$ \\
\hline & & \multirow{2}{*}{$\begin{array}{c}\text { D14 - Reconhecer a } \\
\text { finalidade de gêneros } \\
\text { diversos. }\end{array}$} & $\begin{array}{l}\text { N1 - Identificar a finalidade de um } \\
\text { gênero textual, a partir de seu modo de } \\
\text { apresentação. }\end{array}$ & $X$ & $X$ & $\mathrm{X}$ \\
\hline & & & $\begin{array}{l}\text { N2 - Identificar a finalidade de textos de } \\
\text { diferentes gêneros, a partir de seu } \\
\text { tema/assunto. }\end{array}$ & $X$ & $X$ & $\mathrm{X}$ \\
\hline \multirow{6}{*}{$\begin{array}{l}\text { T4- Leitura: } \\
\text { compreensão, } \\
\text { análise e } \\
\text { avaliação. }\end{array}$} & \multirow{6}{*}{$\begin{array}{l}\text { C7. Localização } \\
\text { de informações } \\
\text { explícitas em } \\
\text { textos. }\end{array}$} & \multirow{2}{*}{$\begin{array}{l}\text { D15 - Localizar } \\
\text { informações explícitas } \\
\text { em textos de maior } \\
\text { extensão ou em textos } \\
\text { que apresentam dados. }\end{array}$} & $\begin{array}{l}\text { N1 - Localizar informações explícitas } \\
\text { em textos (curtos, médios ou longos) }\end{array}$ & $X$ & $\mathrm{X}$ & $\mathrm{X}$ \\
\hline & & & $\begin{array}{l}\text { N2 - Localizar informações explícitas, } \\
\text { em textos que têm por finalidade geral } \\
\text { apresentar dados (mapas, gráficos, } \\
\text { tabelas, etc.). }\end{array}$ & $X$ & $\mathrm{X}$ & $\mathrm{X}$ \\
\hline & & D16 - Identificar & $\begin{array}{l}\text { N1 - Identificar personagens e suas } \\
\text { ações. }\end{array}$ & $X$ & $\mathrm{X}$ & $\mathrm{X}$ \\
\hline & & elementos que & N2 - Identificar espaço. & & $\mathrm{X}$ & $\mathrm{X}$ \\
\hline & & constroem a narrativa. & N3 - Identificar tempo. & & $\mathrm{X}$ & $\mathrm{X}$ \\
\hline & & & N4 - Identificar o conflito gerador. & & & $\mathrm{X}$ \\
\hline
\end{tabular}




\begin{tabular}{|c|c|c|c|c|c|}
\hline \multirow{8}{*}{$\begin{array}{c}\text { C8. } \\
\text { Interpretação de } \\
\text { informações } \\
\text { implícitas em } \\
\text { textos. }\end{array}$} & \multirow{4}{*}{$\begin{array}{c}\text { D17 - Inferir } \\
\text { informações implícitas } \\
\text { em textos }\end{array}$} & $\begin{array}{l}\text { N1 - Inferir o sentido de uma palavra ou } \\
\text { expressão. }\end{array}$ & & $X$ & $X$ \\
\hline & & $\begin{array}{l}\mathrm{N} 2 \text { - Inferir uma informação em textos } \\
\text { não verbais. }\end{array}$ & $X$ & $X$ & $X$ \\
\hline & & $\begin{array}{l}\text { N3 - Identificar informações implícitas, } \\
\text { estabelecidas na relação entre texto e } \\
\text { imagem. }\end{array}$ & & $X$ & $X$ \\
\hline & & $\begin{array}{l}\text { N4 - Inferir uma informação em textos } \\
\text { curtos e/ou de média extensão. }\end{array}$ & $X$ & $X$ & $X$ \\
\hline & $\begin{array}{l}\text { D18 - Identificar } \\
\text { assunto de textos. }\end{array}$ & \multirow{2}{*}{$\begin{array}{l}\text { N3 - Identificar assunto de textos, sem o } \\
\text { apoio de imagens } \\
\text { N1 - Formular hipótese sobre assunto } \\
\text { do texto, a partir de imagens. } \\
\text { N2 - Formular hipótese sobre assunto de } \\
\text { texto, a partir do título. } \\
\text { N3 - Formular hipóteses sobre como um } \\
\text { texto continua a partir de } \\
\text { seu início. }\end{array}$} & $X$ & $X$ & $X$ \\
\hline & $\begin{array}{l}\text { D19 - Formular } \\
\text { hipóteses }\end{array}$ & & $X$ & $X$ & $X$ \\
\hline & \multirow[t]{2}{*}{$\begin{array}{l}\text { D20 - Identificar } \\
\text { efeitos de humor em } \\
\text { textos diversos. }\end{array}$} & $\begin{array}{l}\text { N1 - Identificar efeitos de humor ou } \\
\text { ironia em textos que integrem elementos } \\
\text { verbais e não verbais (tirinhas, charges, } \\
\text { propagandas,...). }\end{array}$ & & $X$ & $X$ \\
\hline & & $\begin{array}{l}\mathrm{N} 2 \text { - Identificar efeitos de humor ou } \\
\text { ironia em textos verbais (piadas...). }\end{array}$ & & $X$ & $X$ \\
\hline
\end{tabular}




\begin{tabular}{|c|c|c|c|}
\hline \multirow{2}{*}{$\begin{array}{l}\text { D21 - Estabelecer } \\
\text { relações } \\
\text { lógicodiscursivas } \\
\text { presentes no texto. }\end{array}$} & $\begin{array}{l}\text { N1 - Estabelecer relações } \\
\text { lógicodiscursivas marcadas por } \\
\text { conjunções (aditiva, adversativa, } \\
\text { temporal, causal). }\end{array}$ & $X$ & X \\
\hline & $\begin{array}{l}\text { N2 - Estabelecer relações } \\
\text { lógicodiscursivas marcadas por } \\
\text { advérbios (tempo, lugar) }\end{array}$ & & $X$ \\
\hline \multirow{3}{*}{$\begin{array}{c}\mathrm{D} 22 \text { - Estabelecer } \\
\text { relações de } \\
\text { continuidade temática, } \\
\text { a partir da recuperação } \\
\text { de elementos da } \\
\text { cadeia referencial do } \\
\text { texto. }\end{array}$} & $\begin{array}{l}\text { N1 - Identificar descrições definidas que } \\
\text { contribuem para a continuidade de um } \\
\text { texto. }\end{array}$ & $X$ & $X$ \\
\hline & $\begin{array}{l}\mathrm{N} 2 \text { - Identificar substituições } \\
\text { pronominais (somente com pronomes } \\
\text { pessoais do caso reto) que contribuem } \\
\text { para a continuidade de um texto. }\end{array}$ & $X$ & $X$ \\
\hline & $\begin{array}{l}\mathrm{N} 3 \text { - Recuperar o antecedente de um } \\
\text { elemento anafórico, representado por } \\
\text { elipse. }\end{array}$ & & $X$ \\
\hline \multirow{3}{*}{$\begin{array}{l}\text { D23 - Identificar o } \\
\text { efeito de sentido } \\
\text { decorrente do uso de } \\
\text { recursos gráficos, da } \\
\text { pontuação, da seleção } \\
\text { lexical e repetições. }\end{array}$} & $\begin{array}{l}\text { N1 - Identificar efeito de sentido } \\
\text { decorrente do uso de letras maiúsculas. }\end{array}$ & $X$ & $X$ \\
\hline & $\begin{array}{l}\text { N2 - Identificar efeito de sentido } \\
\text { decorrente do uso de pontuação. }\end{array}$ & $X$ & $X$ \\
\hline & $\begin{array}{l}\text { N3 - Identificar efeito de sentido } \\
\text { decorrente do uso de outras notações } \\
\text { gráficas (negrito, itálico, fonte, tamanho } \\
\text { da letra...). }\end{array}$ & $X$ & $X$ \\
\hline
\end{tabular}




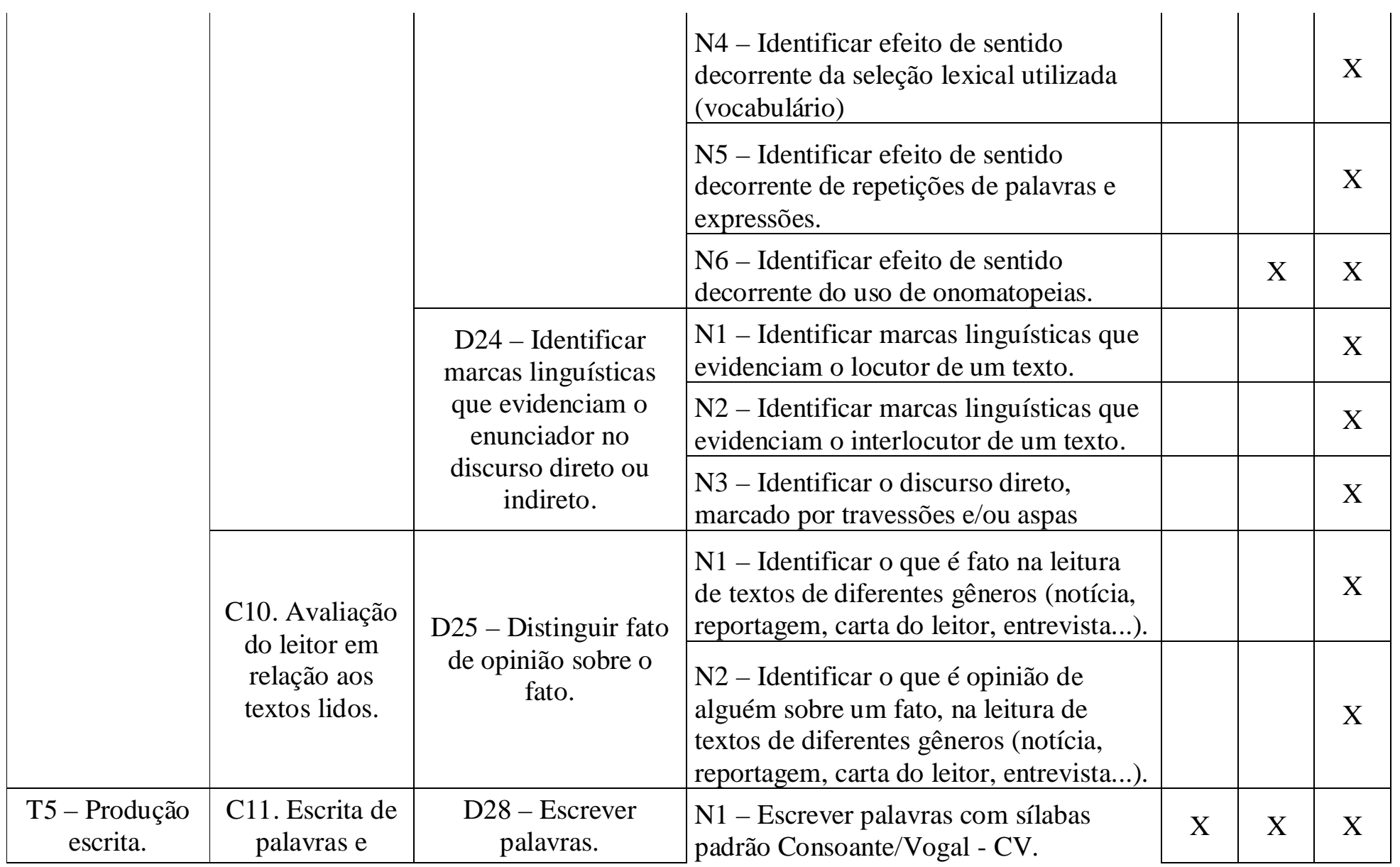




\begin{tabular}{|c|c|c|c|c|c|}
\hline \multirow[t]{7}{*}{ frases. } & & $\begin{array}{l}\text { N2 - Escrever palavras com sílabas } \\
\text { Consoante/Vogal/Consoante - CVC. }\end{array}$ & $X$ & $\mathrm{X}$ & $\mathrm{X}$ \\
\hline & & $\begin{array}{l}\text { N3 - Escrever palavras com sílabas } \\
\text { Consoante/Consoante/Vogal - CCV. }\end{array}$ & $\mathrm{X}$ & $\mathrm{X}$ & $\mathrm{X}$ \\
\hline & & $\begin{array}{l}\text { N4 - Escrever palavras com sílabas } \\
\text { Vogal/Consoante - VC. }\end{array}$ & $\mathrm{X}$ & $\mathrm{X}$ & $\mathrm{X}$ \\
\hline & & $\begin{array}{l}\text { N5 - Escrever palavras com sílaba } \\
\text { Vogal - V. }\end{array}$ & $\mathrm{X}$ & $\mathrm{X}$ & $\mathrm{X}$ \\
\hline & & $\begin{array}{l}\text { N6 - Escrever palavras que contenham } \\
\text { ditongo e/ou dígrafo. }\end{array}$ & $\mathrm{X}$ & $\mathrm{X}$ & $\mathrm{X}$ \\
\hline & \multirow{2}{*}{ D29 - Escrever frases. } & $\begin{array}{l}\text { N1 - Escrever frases, a partir de uma } \\
\text { imagem. }\end{array}$ & $\mathrm{X}$ & $\mathrm{X}$ & $\mathrm{X}$ \\
\hline & & $\begin{array}{l}\text { N2 - Escrever frases, a partir de um } \\
\text { ditado. }\end{array}$ & $\mathrm{X}$ & $\mathrm{X}$ & $\mathrm{X}$ \\
\hline \multirow{4}{*}{$\begin{array}{l}\text { C12. Produção } \\
\text { de textos. }\end{array}$} & \multirow{4}{*}{ D30 - Produzir textos. } & $\begin{array}{l}\text { N1 - Escrever uma lista de palavras, a } \\
\text { partir de elementos de uma imagem. }\end{array}$ & $X$ & & \\
\hline & & $\begin{array}{l}\text { N2 - Produzir textos de gêneros } \\
\text { familiares como: lista, bilhete. }\end{array}$ & & $X$ & $\mathrm{X}$ \\
\hline & & $\begin{array}{l}\text { N3 - Produzir uma pequena história, a } \\
\text { partir de uma sequência de imagens. }\end{array}$ & $\mathrm{X}$ & $\mathrm{X}$ & $\mathrm{X}$ \\
\hline & & $\begin{array}{l}\text { N4 - Produzir histórias/contos (reais ou } \\
\text { fictícios) que relatem episódios de medo, } \\
\text { susto, surpresa, alegria, etc. }\end{array}$ & $X$ & $\mathrm{X}$ & $\mathrm{X}$ \\
\hline
\end{tabular}




\title{
ANEXO 2
}

\section{Interpretação Pedagógica da escala de proficiência em Leitura e Escrita - PAEBES-Alfa}

\section{LEITURA \\ $1^{\circ}$ ANO DO ENSINO FUNDAMENTAL}

\begin{abstract}
ABAIXO DO BÁSICO - até 400
Os estudantes que se encontram no Padrão de Desempenho Abaixo do Básico apresentam as primeiras manifestações de habilidades relacionadas à apropriação do sistema de escrita. Essas habilidades dizem respeito tanto a aspectos gráficos identificação de letras - quanto sonoros - consciência fonológica. Dado o caráter inicial do processo de alfabetização, as habilidades de leitura são ainda incipientes neste Padrão, o que demanda uma intervenção pedagógica focalizada em tarefas que possibilitem o desenvolvimento de habilidades do eixo da Matriz de Referência denominado Apropriação do sistema alfabético. No que se referem aos aspectos gráficos, as crianças que apresentam este Padrão de Desempenho fazem distinção entre a escrita e outras formas de representação, como desenhos, garatujas, formas geométricas e/ou outros símbolos. Isso significa que reconhecem que na escrita são usadas letras, embora ainda não saibam como agrupá-las de forma convencional na leitura. A partir dos 250 pontos de proficiência, os estudantes já identificam algumas letras do alfabeto (especialmente as iniciais), quando apresentadas isoladamente ou em um conjunto de letras (sequência de três letras). Os estudantes com proficiência a partir de $\mathbf{3 0 0}$ pontos, além das habilidades descritas anteriormente, identificam a sílaba inicial de uma palavra, especialmente em palavras formadas exclusivamente por sílabas no padrão canônico (consoante/vogal). Este fato indica que as crianças que se encontram neste nível de proficiência percebem as relações entre fala e escrita de forma mais sistemática, demonstrando que desenvolveram habilidades específicas da consciência fonológica. Estudantes que estão no limite da passagem deste Padrão ao seguinte - entre 350 e 400 pontos -, além de terem consolidado as habilidades relacionadas à identificação de letras do alfabeto, reconhecem uma mesma letra, ou sequência de letras, grafada em diferentes padrões gráficos (maiúscula, minúscula, de imprensa, cursiva). Esses estudantes leem silenciosamente palavras dissílabas e trissílabas, especialmente as paroxítonas, quando formadas exclusivamente por sílabas no padrão canônico, ou por sílaba formada exclusivamente por uma vogal. Tal constatação indica que esses estudantes resolvem tarefas relacionadas a habilidades iniciais de leitura de palavras, sendo esse um marco importante de seu processo de alfabetização.
\end{abstract}

\section{BÁSICO - de 400 a 500 pontos}

Os estudantes que apresentam o Padrão de Desempenho Básico desenvolveram todas as habilidades de leitura descritas no Padrão de Desempenho Abaixo do Básico. Além daquelas habilidades, os estudantes com nível de proficiência entre 400 e 450 pontos realizam a leitura de palavras dissílabas ou trissílabas, paroxítonas, formadas por diferentes estruturas silábicas (sílaba no padrão $\mathrm{CV}$, $\mathrm{CVC}$, ditongo). Essas crianças realizam tarefas que envolvem a habilidade de 
identificar o tipo de suporte no qual circulam gêneros textuais mais familiares. Este fato indica a primeira ocorrência de uma habilidade relacionada ao tópico Usos sociais da leitura e da escrita, da Matriz de Referência. Os estudantes que estão no limite da passagem deste Padrão de Desempenho ao seguinte, entre 450 e 500 pontos, leem palavras formadas por diferentes padrões silábicos, atribuindo sentido ao que leem. Além disso, identificam o gênero ao qual pertencem alguns textos mais familiares, como por exemplo, receita. Surgem, neste nível, as primeiras ocorrências de habilidade de leitura de frases na ordem direta (sujeito, verbo, objeto) com identificação de informações nelas explícitas. Também aparecem ocorrências de localização de informações explícitas (que se encontram na superfície textual) em textos curtos e de gênero familiar ao contexto escolar, como parlendas e textos que informam sobre curiosidades. Em textos narrativos curtos (entre três e quatro linhas), os estudantes que apresentam este nível de proficiência identificam elementos, como o tempo em que ocorre um determinado fato e a personagem principal da narrativa. Em seu conjunto, o desenvolvimento de habilidades de leitura relacionadas a este Padrão de Desempenho caracteriza um leitor que começa a ler e interpretar pequenos textos com alguma autonomia.

\section{PROFICIENTE - de 500 a 600 pontos}

Os estudantes que apresentam Padrão de Desempenho Proficiente desenvolveram, além das habilidades de leitura descritas anteriormente, outras que ampliam suas possibilidades de interação com os textos como leitores, o que permite afirmar que são considerados alfabetizados. Aqueles com proficiência entre 500 e 550 pontos identificam o número de palavras que formam um texto de, por exemplo, 18 palavras, demonstrando, dessa forma, que compreendem essa unidade gráfica do sistema alfabético. Tais estudantes aprimoram habilidades relacionadas à consciência fonológica, uma vez que realizam tarefas de contagem de sílabas em palavras formadas por diferentes padrões silábicos. Conseguem ainda identificar sílabas no padrão canônico (consoante/vogal) no final de palavras. Em relação às habilidades de leitura de textos, além daquelas já descritas no Padrão de Desempenho Básico, e que se referem à localização de informações explícitas em textos curtos, as crianças que se encontram neste Padrão de Desempenho realizam inferências a partir da leitura de textos que conjugam linguagem verbal e não verbal, como histórias em quadrinhos e tirinhas. Trata-se de gêneros que, geralmente, circulam nas esferas escolares. No que diz respeito às habilidades relacionadas aos usos sociais de gêneros e suportes textuais, neste Padrão de Desempenho as crianças identificam gêneros textuais menos familiares, como a carta, e a finalidade ou assunto de textos de gêneros familiares, como bilhete, lista de compras, folheto, tabela de preços. Aparecem também atividades que envolvem a habilidade de identificar portadores de textos nos quais as palavras estão organizadas em ordem alfabética. Os estudantes com proficiência entre 550 e 600 pontos, que se encontram, portanto, no limite para a passagem ao próximo Padrão de Desempenho, consolidaram habilidades relacionadas à consciência fonológica, como a de identificar sons iniciais e/ou finais de palavras formadas por sílabas no padrão $\mathrm{CV}$ e também as relativas à leitura de palavras em diferentes extensões e padrões silábicos. As habilidades relacionadas à localização de informações em texto se expandem, uma vez que os estudantes que se encontram neste nível localizam informações em textos de diversos gêneros, 
inclusive gráficos e tabelas, podendo tal informação estar no início, meio ou fim do texto. Aprimoram-se, também, as habilidades de identificar elementos de uma narrativa tais como personagem e espaço e aquelas relacionadas à identificação de gênero, finalidade e assunto de textos, assim como se amplia a extensão dos textos que esses estudantes conseguem ler. Além de inferirem informações em textos exclusivamente não verbais, os estudantes que apresentam este nível de proficiência inferem o sentido de uma palavra ou expressão. Esses estudantes ampliam sua relação com a habilidade da ordem alfabética, tanto no que se refere aos suportes, quanto à alocação de palavras a partir da observação das letras iniciais.

\section{AVANÇADO - acima de 600 pontos}

A principal característica dos estudantes que apresentam proficiência compatível com o Padrão de Desempenho Avançado é o fato de terem desenvolvido habilidades de leitura além daquelas esperadas para a etapa de escolarização em que se encontram. Este Padrão abriga vários níveis de desempenho, portanto as habilidades descritas apresentam diferentes níveis de complexidade, a depender da proficiência dos estudantes. Os estudantes que se encontram no nível até $\mathbf{6 5 0}$ pontos, além de localizarem sílabas iniciais e finais de palavras formadas exclusivamente pelo padrão $\mathrm{CV}$, reconhecem sílabas mediais dessas palavras. Além disso, consolidaram o conceito de palavra, sendo capazes de contá-las em textos mais extensos. Quanto às habilidades de leitura, elas se ampliam, tanto aquelas que se referem à apreensão de elementos que se encontram na superfície textual e à identificação de elementos da narrativa, quanto àquelas que dizem respeito à realização de inferências do sentido de palavras e expressões. Apropriam-se também das habilidades relacionadas aos usos sociais da leitura e da escrita, o que indica que esses estudantes demonstram ter maior familiaridade com gêneros textuais diversos. Os estudantes com proficiência entre 650 e 700 pontos desenvolveram habilidades mais sofisticadas, ligadas à consciência fonológica, como a habilidade de contar sílabas de palavras de diferentes extensões e formadas por diferentes padrões silábicos, assim como o reconhecimento de diferenças sonoras entre palavras que se diferenciam por apenas um fonema. Quanto às habilidades do eixo Leitura: compreensão, análise $e$ avaliação, a interação com textos narrativos revela que tais estudantes identificam o conflito gerador em narrativas, assim como reconhecem o locutor de um texto de curta extensão e já conseguem identificar, num texto, a quem pertence a fala de uma personagem. As habilidades de realização de inferência também se expandem, pois os estudantes que se encontram neste nível de proficiência conseguem inferir o assunto de um texto a partir de seu título, de perceber o que provoca o efeito de humor num texto e de reconhecer o efeito de sentido produzido pelo uso de onomatopeias em poesias. A partir dos $\mathbf{7 0 0}$ pontos, os estudantes ampliam a habilidade de inferir informações em textos que conjugam linguagem verbal e não verbal, como tirinhas. Outra habilidade que aparece neste nível é a de identificar a relação entre pronomes anafóricos e seus referentes. Os estudantes com $\mathbf{7 5 0}$ pontos de proficiência ampliaram a habilidade de inserção de uma palavra na ordem alfabética, tendo como referência a segunda ou a terceira letra da palavra. Aprimora-se ainda a habilidade de inferir o sentido de uma palavra ou expressão em texto curto. Outra habilidade que se amplia é a de identificar o efeito de sentido decorrente do uso de sinais de pontuação. Nesse 
intervalo, o estudante consegue identificar o interlocutor em textos como propagandas. A partir dos $\mathbf{8 0 0}$ pontos de proficiência, constata-se a ampliação das habilidades de leitura anteriormente referidas, especialmente aquelas ligadas ao estabelecimento de relações lógico- discursivas entre partes ou elementos dos textos, como relações de causa e consequência e relações lógico-discursivas marcadas por conjunção temporal ou advérbio de tempo. Observa-se, portanto, que as principais conquistas a partir deste nível de proficiência dizem respeito à capacidade de interagir com os textos percebendo as relações existentes entre as diferentes partes que os constituem.

\section{$2^{\circ}$ ANO DO ENSINO FUNDAMENTAL}

\section{ABAIXO DO BÁSICO - até 500 pontos}

Os estudantes que se encontram no Padrão de Desempenho Abaixo do Básico apresentam as primeiras manifestações de habilidades relacionadas à apropriação do sistema de escrita. Essas habilidades dizem respeito tanto a aspectos gráficos identificação de letras - quanto sonoros - consciência fonológica. Dado o caráter inicial do processo de alfabetização, as habilidades de leitura são ainda incipientes neste Padrão, o que demanda uma intervenção pedagógica focalizada em tarefas que possibilitem o desenvolvimento de habilidades do eixo da Matriz de Referência denominado Apropriação do sistema alfabético. No que se referem aos aspectos gráficos, as crianças que apresentam este Padrão de Desempenho fazem distinção entre a escrita e outras formas de representação, como desenhos, garatujas, formas geométricas e/ou outros símbolos. Isso significa que reconhecem que na escrita são usadas letras, embora ainda não saibam como agrupá-las de forma convencional na leitura. A partir dos 250 pontos de proficiência, os estudantes já identificam algumas letras do alfabeto (especialmente as iniciais), quando apresentadas isoladamente ou em um conjunto de letras (sequência de três letras). Os estudantes com proficiência a partir de $\mathbf{3 0 0}$ pontos, além das habilidades descritas anteriormente, identificam a sílaba inicial de uma palavra, especialmente em palavras formadas exclusivamente por sílabas no padrão canônico (consoante/vogal). Este fato indica que as crianças que se encontram neste nível de proficiência percebem as relações entre fala e escrita de forma mais sistemática, demonstrando que desenvolveram habilidades específicas da consciência fonológica. Aqueles que estão no limite da passagem deste Padrão ao seguinte - entre 350 e 400 pontos -, além de terem consolidado as habilidades relacionadas à identificação de letras do alfabeto, reconhecem uma mesma letra, ou sequência de letras, grafada em diferentes padrões gráficos (maiúscula, minúscula, de imprensa, cursiva). Esses estudantes leem silenciosamente palavras dissílabas e trissílabas, especialmente as paroxítonas, quando formadas exclusivamente por sílabas no padrão canônico, ou por sílaba formada exclusivamente por uma vogal. Tal constatação indica que resolvem tarefas relacionadas a habilidades iniciais de leitura de palavras, sendo esse um marco importante de seu processo de alfabetização. Além das habilidades citadas anteriormente, os estudantes deste Padrão de Desempenho realizam a leitura de palavras dissílabas ou trissílabas, paroxítonas, formadas por diferentes estruturas silábicas (sílaba no padrão $\mathrm{CV}, \mathrm{CVC}$, ditongo). Essas crianças realizam tarefas que envolvem a habilidade de identificar o tipo de suporte no qual circulam gêneros textuais mais familiares. Este fato indica a primeira ocorrência de uma 
habilidade relacionada ao tópico Usos sociais da leitura e da escrita, da Matriz de Referência. Os estudantes que estão no limite da passagem deste Padrão de Desempenho ao seguinte, entre 450 e 500 pontos, leem palavras formadas por diferentes padrões silábicos, atribuindo sentido ao que leem. Além disso, identificam o gênero ao qual pertencem alguns textos mais familiares, como por exemplo, receita. Surgem, neste nível, as primeiras ocorrências de habilidade de leitura de frases na ordem direta (sujeito, verbo, objeto) com identificação de informações nelas explícitas. Também aparecem ocorrências de localização de informações explícitas (que se encontram na superfície textual) em textos curtos e de gênero familiar ao contexto escolar, como parlendas e textos que informam sobre curiosidades. Em textos narrativos curtos (entre três e quatro linhas), os estudantes que apresentam este nível de proficiência identificam elementos, como o tempo em que ocorre um determinado fato e a personagem principal da narrativa. Em seu conjunto, o desenvolvimento de habilidades de leitura relacionadas a este Padrão de Desempenho caracteriza um leitor que começa a ler e interpretar pequenos textos com alguma autonomia.

\section{BÁSICO - de 500 a 600 pontos}

Os estudantes que se encontram no Padrão de Desempenho Básico desenvolveram todas as habilidades de leitura descritas no Padrão de Desempenho Abaixo do Básico. Aqueles com proficiência entre 500 e 550 pontos identificam o número de palavras que formam um texto de, por exemplo, 18 palavras, demonstrando, dessa forma, que compreendem essa unidade gráfica do sistema alfabético. Tais estudantes aprimoram habilidades relacionadas à consciência fonológica, uma vez que realizam tarefas de contagem de sílabas em palavras formadas por diferentes padrões silábicos. Conseguem ainda identificar sílabas no padrão canônico (consoante/vogal) no final de palavras. Em relação às habilidades de leitura de textos, além daquelas já descritas no Padrão de Desempenho Abaixo do Básico, e que se referem à localização de informações explícitas em textos curtos, as crianças que se encontram neste Padrão de Desempenho realizam inferências a partir da leitura de textos que conjugam linguagem verbal e não verbal, como histórias em quadrinhos e tirinhas. Trata-se de gêneros que, geralmente, circulam nas esferas escolares. No que diz respeito às habilidades relacionadas aos usos sociais de gêneros e suportes textuais, neste Padrão de Desempenho as crianças identificam gêneros textuais menos familiares, como a carta, e a finalidade ou assunto de textos de gêneros familiares, como bilhete, lista de compras, folheto, tabela de preços. Aparecem também atividades que envolvem a habilidade de identificar portadores de textos nos quais as palavras estão organizadas em ordem alfabética. Os estudantes com proficiência entre 550 e 600 pontos, que se encontram, portanto, no limite para a passagem ao próximo Padrão de Desempenho, consolidaram habilidades relacionadas à consciência fonológica, como a de identificar sons iniciais e/ou finais de palavras formadas por sílabas no padrão CV e também as relativas à leitura de palavras em diferentes extensões e padrões silábicos. As habilidades relacionadas à localização de informações em texto se expandem, uma vez que os estudantes que se encontram neste nível localizam informações em textos de diversos gêneros, inclusive gráficos e tabelas, podendo tal informação estar no início, meio ou fim do texto. Aprimoram-se, também, as habilidades de identificar elementos de uma narrativa tais como personagem e espaço e aquelas relacionadas à identificação de gênero, finalidade 
e assunto de textos, assim como se amplia a extensão dos textos que esses estudantes conseguem ler. Além de inferirem informações em textos exclusivamente não verbais, os estudantes que apresentam este nível de proficiência inferem o sentido de uma palavra ou expressão. Esses estudantes ampliam sua relação com a habilidade da ordem alfabética, tanto no que se refere aos suportes, quanto à alocação de palavras a partir da observação das letras iniciais.

\section{PROFICIENTE - de 600 a 700 pontos}

Os estudantes que apresentam Padrão de Desempenho Proficiente desenvolveram, além das habilidades de leitura descritas anteriormente, outras que ampliam suas possibilidades de interação com os textos como leitores, o que permite afirmar que são considerados alfabetizados. Aqueles que se encontram no nível de proficiência até $\mathbf{6 5 0}$ pontos, além de localizarem sílabas iniciais e finais de palavras formadas exclusivamente pelo padrão $\mathrm{CV}$, reconhecem sílabas mediais dessas palavras. Além disso, consolidaram o conceito de palavra, sendo capazes de contá-las em textos mais extensos. Quanto às habilidades de leitura, elas se ampliam, tanto aquelas que se referem à apreensão de elementos que se encontram na superfície textual e à identificação de elementos da narrativa, quanto àquelas que dizem respeito à realização de inferências do sentido de palavras e expressões. Apropriam-se também das habilidades relacionadas aos usos sociais da leitura e da escrita, o que indica que esses estudantes demonstram ter maior familiaridade com gêneros textuais diversos. Os estudantes com proficiência entre 650 e 700 pontos desenvolveram habilidades mais sofisticadas, ligadas à consciência fonológica, como a habilidade de contar sílabas de palavras de diferentes extensões e formadas por diferentes padrões silábicos, assim como o reconhecimento de diferenças sonoras entre palavras que se diferenciam por apenas um fonema. Quanto às habilidades do eixo Leitura: compreensão, análise $e$ avaliação, a interação com textos narrativos revela que tais estudantes identificam o conflito gerador em narrativas, assim como reconhecem o locutor de um texto de curta extensão e já conseguem identificar, num texto, a quem pertence a fala de uma personagem. As habilidades de realização de inferência também se expandem, pois os estudantes que se encontram neste nível de proficiência conseguem inferir o assunto de um texto a partir de seu título, de perceber o que provoca o efeito de humor num texto e de reconhecer o efeito de sentido produzido pelo uso de onomatopeias em poesias.

\section{AVANÇADO - acima de 700 pontos}

A principal característica dos estudantes que apresentam proficiência compatível com o Padrão de Desempenho Avançado é o fato de terem desenvolvido habilidades de leitura além daquelas esperadas para a etapa de escolarização em que se encontram. Este Padrão abriga vários níveis de desempenho, portanto as habilidades descritas apresentam diferentes níveis de complexidade, a depender da proficiência dos estudantes. Os estudantes que se encontram no nível de proficiência de até $\mathbf{7 0 0}$ pontos ampliam a habilidade de inferir informações em textos que conjugam linguagem verbal e não verbal, como tirinhas. Outra habilidade que aparece neste nível é a de identificar a relação entre pronomes anafóricos e seus referentes. Aqueles com $\mathbf{7 5 0}$ pontos de proficiência ampliaram a habilidade de inserção de uma palavra na ordem alfabética, tendo como referência 
a segunda ou a terceira letra da palavra. Aprimora-se ainda a habilidade de inferir o sentido de uma palavra ou expressão em texto curto. Outra habilidade que se amplia é a de identificar o efeito de sentido decorrente do uso de sinais de pontuação. Nesse intervalo, o estudante consegue identificar o interlocutor em textos como propagandas. A partir dos $\mathbf{8 0 0}$ pontos de proficiência, constata-se a ampliação das habilidades de leitura anteriormente referidas, especialmente aquelas ligadas ao estabelecimento de relações lógico- discursivas entre partes ou elementos dos textos, como relações de causa e consequência e relações lógicodiscursivas marcadas por conjunção temporal ou advérbio de tempo. Observa-se, portanto, que as principais conquistas a partir deste nível de proficiência dizem respeito à capacidade de interagir com os textos percebendo as relações existentes entre as diferentes partes que os constituem.

\section{$3^{\circ}$ ANO DO ENSINO FUNDAMENTAL}

\section{ABAIXO DO BÁSICO - até 600}

Os estudantes que se encontram no Padrão de Desempenho Abaixo do Básico apresentam as primeiras manifestações de habilidades relacionadas à apropriação do sistema de escrita. Essas habilidades dizem respeito tanto a aspectos gráficos identificação de letras - quanto sonoros - consciência fonológica. Dado o caráter inicial do processo de alfabetização, as habilidades de leitura são ainda incipientes neste Padrão, o que demanda uma intervenção pedagógica focalizada em tarefas que possibilitem o desenvolvimento de habilidades do eixo da Matriz de Referência denominado Apropriação do sistema alfabético. No que se referem aos aspectos gráficos, as crianças que apresentam este Padrão de Desempenho fazem distinção entre a escrita e outras formas de representação, como desenhos, garatujas, formas geométricas e/ou outros símbolos. Isso significa que reconhecem que na escrita são usadas letras, embora ainda não saibam como agrupá-las de forma convencional na leitura. A partir dos 250 pontos de proficiência, os estudantes já identificam algumas letras do alfabeto (especialmente as iniciais), quando apresentadas isoladamente ou em um conjunto de letras (sequência de três letras). Os estudantes com proficiência a partir de $\mathbf{3 0 0}$ pontos, além das habilidades descritas anteriormente, identificam a sílaba inicial de uma palavra, especialmente em palavras formadas exclusivamente por sílabas no padrão canônico (consoante/vogal). Este fato indica que as crianças que se encontram neste nível de proficiência percebem as relações entre fala e escrita de forma mais sistemática, demonstrando que desenvolveram habilidades específicas da consciência fonológica. Aqueles que estão no limite da passagem deste Padrão ao seguinte - entre 350 e 400 pontos -, além de terem consolidado as habilidades relacionadas à identificação de letras do alfabeto, reconhecem uma mesma letra, ou sequência de letras, grafada em diferentes padrões gráficos (maiúscula, minúscula, de imprensa, cursiva). Esses estudantes leem silenciosamente palavras dissílabas e trissílabas, especialmente as paroxítonas, quando formadas exclusivamente por sílabas no padrão canônico, ou por sílaba formada exclusivamente por uma vogal. Tal constatação indica que resolvem tarefas relacionadas a habilidades iniciais de leitura de palavras, sendo esse um marco importante de seu processo de alfabetização. Além das habilidades citadas anteriormente, os estudantes deste Padrão de Desempenho realizam a leitura de palavras dissílabas ou trissílabas, paroxítonas, formadas por diferentes estruturas 
silábicas (sílaba no padrão $\mathrm{CV}, \mathrm{CVC}$, ditongo). Essas crianças realizam tarefas que envolvem a habilidade de identificar o tipo de suporte no qual circulam gêneros textuais mais familiares. Este fato indica a primeira ocorrência de uma habilidade relacionada ao tópico Usos sociais da leitura e da escrita, da Matriz de Referência. Os estudantes que se encontram entre 450 e 500 pontos, leem palavras formadas por diferentes padrões silábicos, atribuindo sentido ao que leem. Além disso, identificam o gênero ao qual pertencem alguns textos mais familiares, como por exemplo, receita. Surgem, neste nível, as primeiras ocorrências de habilidade de leitura de frases na ordem direta (sujeito, verbo, objeto) com identificação de informações nelas explícitas. Também aparecem ocorrências de localização de informações explícitas (que se encontram na superfície textual) em textos curtos e de gênero familiar ao contexto escolar, como parlendas e textos que informam sobre curiosidades. Em textos narrativos curtos (entre três e quatro linhas), os estudantes que apresentam este nível de proficiência identificam elementos, como o tempo em que ocorre um determinado fato e a personagem principal da narrativa. Aqueles com proficiência entre 500 e 550 pontos identificam o número de palavras que formam um texto de, por exemplo, 18 palavras, demonstrando, dessa forma, que compreendem essa unidade gráfica do sistema alfabético. Tais estudantes aprimoram habilidades relacionadas à consciência fonológica, uma vez que realizam tarefas de contagem de sílabas em palavras formadas por diferentes padrões silábicos. Conseguem ainda identificar sílabas no padrão canônico (consoante/vogal) no final de palavras.

Em relação às habilidades de leitura de textos, além que se referem à localização de informações explícitas em textos curtos, as crianças que se encontram neste Padrão de Desempenho realizam inferências a partir da leitura de textos que conjugam linguagem verbal e não verbal, como histórias em quadrinhos e tirinhas. Trata-se de gêneros que, geralmente, circulam nas esferas escolares. No que diz respeito às habilidades relacionadas aos usos sociais de gêneros e suportes textuais, neste Padrão de Desempenho da habilidade as crianças identificam gêneros textuais menos familiares, como a carta, e a finalidade ou assunto de textos de gêneros familiares, como bilhete, lista de compras, folheto, tabela de preços. Aparecem também atividades que envolvem a habilidade de identificar portadores de textos nos quais as palavras estão organizadas em ordem alfabética. Os estudantes que estão no limite da passagem deste Padrão de Desempenho ao seguinte, com proficiência entre 550 e 600 pontos, consolidaram habilidades relacionadas à consciência fonológica, como a de identificar sons iniciais e/ou finais de palavras formadas por sílabas no padrão $\mathrm{CV}$ e também as relativas à leitura de palavras em diferentes extensões e padrões silábicos. As habilidades relacionadas à localização de informações em texto se expandem, uma vez que os estudantes que se encontram neste nível localizam informações em textos de diversos gêneros, inclusive gráficos e tabelas, podendo tal informação estar no início, meio ou fim do texto. Aprimoram-se, também, as habilidades de identificar elementos de uma narrativa tais como personagem e espaço e aquelas relacionadas à identificação de gênero, finalidade e assunto de textos, assim como se amplia a extensão dos textos que esses estudantes conseguem ler.

Além de inferirem informações em textos exclusivamente não verbais, os estudantes que apresentam este nível de proficiência inferem o sentido de uma palavra ou expressão. Esses estudantes ampliam sua relação com a habilidade da 
ordem alfabética, tanto no que se refere aos suportes, quanto à alocação de palavras a partir da observação das letras iniciais.

\section{BÁSICO - de 600 a 650 pontos}

Os estudantes que apresentam o Padrão de Desempenho Básico desenvolveram todas as habilidades de leitura descritas no Padrão de Desempenho Abaixo do Básico. Localizam sílabas iniciais e finais de palavras formadas exclusivamente pelo padrão $\mathrm{CV}$, reconhecem sílabas mediais dessas palavras. Além disso, consolidaram o conceito de palavra, sendo capazes de contá-las em textos mais extensos. Quanto às habilidades de leitura, elas se ampliam, tanto aquelas que se referem à apreensão de elementos que se encontram na superfície textual e à identificação de elementos da narrativa, quanto àquelas que dizem respeito à realização de inferências do sentido de palavras e expressões. Apropriam-se também das habilidades relacionadas aos usos sociais da leitura e da escrita, o que indica que esses estudantes demonstram ter maior familiaridade com gêneros textuais diversos.

\section{PROFICIENTE - de 650 a 750 pontos}

Os estudantes que apresentam Padrão de Desempenho Proficiente desenvolveram, além das habilidades de leitura descritas anteriormente, outras que ampliam suas possibilidades de interação com os textos como leitores, o que permite afirmar que são considerados alfabetizados. Aqueles com proficiência entre 650 e 700 pontos desenvolveram habilidades mais sofisticadas, ligadas à consciência fonológica, como a habilidade de contar sílabas de palavras de diferentes extensões e formadas por diferentes padrões silábicos, assim como o reconhecimento de diferenças sonoras entre palavras que se diferenciam por apenas um fonema. Quanto às habilidades do eixo Leitura: compreensão, análise $e$ avaliação, a interação com textos narrativos revela que tais estudantes identificam o conflito gerador em narrativas, assim como reconhecem o locutor de um texto de curta extensão e já conseguem identificar, num texto, a quem pertence a fala de uma personagem. As habilidades de realização de inferência também se expandem, pois os estudantes que se encontram neste nível de proficiência conseguem inferir o assunto de um texto a partir de seu título, de perceber o que provoca o efeito de humor num texto e de reconhecer o efeito de sentido produzido pelo uso de onomatopeias em poesias. A partir dos 700 pontos, os estudantes ampliam a habilidade de inferir informações em textos que conjugam linguagem verbal e não verbal, como tirinhas. Outra habilidade que aparece neste nível é a de identificar a relação entre pronomes anafóricos e seus referentes.

\section{AVANÇADO - acima de 750 pontos}

A principal característica dos estudantes que apresentam proficiência compatível com o Padrão de Desempenho Avançado é o fato de terem desenvolvido habilidades de leitura além daquelas esperadas para a etapa de escolarização em que se encontram. Este Padrão abriga vários níveis de desempenho, portanto as habilidades descritas apresentam diferentes níveis de complexidade, a depender da proficiência dos estudantes. Os estudantes com 750 pontos de proficiência ampliaram a habilidade de inserção de uma palavra na ordem alfabética, tendo como referência a segunda ou a terceira letra da palavra. Aprimora-se ainda a habilidade de inferir o sentido de uma palavra ou expressão em texto curto. Outra 
habilidade que se amplia é a de identificar o efeito de sentido decorrente do uso de sinais de pontuação. Nesse intervalo, o estudante consegue identificar o interlocutor em textos como propagandas. A partir dos 800 pontos de proficiência, constata-se a ampliação das habilidades de leitura anteriormente referidas, especialmente aquelas ligadas ao estabelecimento de relações lógicodiscursivas entre partes ou elementos dos textos, como relações de causa e consequência e relações lógico-discursivas marcadas por conjunção temporal ou advérbio de tempo. Observa-se, portanto, que as principais conquistas a partir deste nível de proficiência dizem respeito à capacidade de interagir com os textos percebendo as relações existentes entre as diferentes partes que os constituem.

\section{ESCRITA}

\section{$1^{\circ}$ ANO DO ENSINO FUNDAMENTAL}

\section{ABAIXO DO BÁSICO - até 400 pontos}

Os estudantes que se encontram neste Padrão de Desempenho começam a desenvolver as habilidades relacionadas à aprendizagem do sistema de escrita. Dado o caráter inicial desse processo, as habilidades de escrita são ainda incipientes. Isso significa que eles reconhecem que, na escrita, são usadas letras, embora ainda não saibam como agrupá-las de forma convencional tanto na leitura quanto na escrita. Assim, neste padrão, os estudantes demonstram já conseguirem observar algumas regras de utilização da página, embora possam não observar os limites das margens ou a necessidade de recomeçar a escrita na margem esquerda ao passarem de uma linha para outra.

\section{BÁSICO - de 400 a 500 pontos}

Os estudantes cuja proficiência está alocada no Padrão de Desempenho Básico, além de demonstrarem já ter desenvolvido todas as habilidades de escrita descritas no Abaixo do Básico, começam a escrever palavras dissílabas, trissílabas ou paroxítonas e em diferentes padrões silábicos, como CV (consoante/vogal), CVC (consoante/vogal/consoante), CVV (consoante/vogal/vogal), V (vogal) e/ou com ditongo(s). No entanto, como ainda se encontram em processo de aprendizagem da língua escrita, ao escreverem, esses estudantes o fazem a partir da hipótese silábica e/ou da hipótese silábico-alfabética. Isso significa que podem usar apenas uma letra para representar cada sílaba da palavra ou, ainda, que podem utilizar ora uma letra para cada sílaba, ora uma letra para cada som da palavra.

\section{PROFICIENTE - de 500 a 600 pontos}

As crianças que apresentam Padrão de Desempenho Proficiente desenvolveram, além das habilidades descritas anteriormente, outras habilidades que ampliam suas possibilidades de interação com os textos enquanto escritores. Esses estudantes apresentam uma escrita que pode ser, em alguns casos, ainda silábico-alfabética e, em outros, alfabética, escrevendo palavras de diferentes extensões e padrões silábicos - CV, VC, CVC, CVV - em conformidade com essas hipóteses de escrita. Uma conquista importante das crianças que apresentam este nível de proficiência é a habilidade de usar a página adequadamente, respeitando margens e a sequência adequada das palavras, inclusive quando há mudança de linha. Elas também produzem uma escrita alfabética de palavras de diferentes extensões e formadas por padrões silábicos variados: CV, VC, CVC, CVV, CVCC, CCVC. 


\section{AVANÇADO - Acima de 600 pontos}

A principal característica dos estudantes que apresentam proficiência compatível com o Padrão de Desempenho Avançado é o fato de terem desenvolvido habilidades de escrita além daquelas esperadas para a etapa de escolarização em que se encontram. Esse Padrão abriga vários níveis de desempenho, portanto, as habilidades descritas apresentam diferentes níveis de complexidade, conforme o intervalo de proficiência em que se encontram os estudantes. Os estudantes com até650 pontos de proficiência começam, a partir de um ditado, a escrever frases curtas, no padrão sintático sujeito/verbo/complemento, com ou sem espaçamento correto entre as palavras. No caso de frases não ditadas, produzidas a partir de uma gravura, inicia-se o desenvolvimento da habilidade de escrevê-las, ainda que no padrão de escrita silábico-alfabética, com ou sem uso de pontuação e de letras maiúsculas no início das frases. No intervalo entre 650 e 700 pontos na escala de proficiência, os estudantes demonstram ganhos significativos quanto à escrita. Observa-se, pois, o início de uma transição de uma escrita alfabética para uma escrita com observância de algumas regras ortográficas, especialmente as contextuais: uso de "l" ou "u" em final de palavra; uso de "ss", "ç" ou "c", dentre outras. Os estudantes escrevem, ainda, palavras com dígrafos, marcas de nasalização e irregularidades ortográficas, como o uso de "s"/“"z"; "s"/“c"; "x"/“ch"; "g"/"j"; "ss"/“ç". No caso da escrita de frases ditadas, observa-se, na maioria dos casos, o uso de espaçamento entre palavras, o que não acontece sempre quando se trata da escrita de frases a partir de imagens. Nesse caso, observa-se plausibilidade da frase escrita em relação à cena apresentada, embora possam aparecer equívocos ortográficos decorrentes da semelhança entre os modos de articulação de alguns sons (transcrição da fala para a escrita). Esses equívocos também ocorrem no caso da escrita de frases ditadas. Nesse padrão, tem início o desenvolvimento de habilidades necessárias à produção de uma escrita ortográfica: observância de regras que orientam o uso de letras que podem representar um mesmo som em diferentes contextos; uso adequado de marcas de nasalização; uso de letras que podem representar um mesmo som em contextos semelhantes. Além disso, os estudantes começam a desenvolver a habilidade de produzir textos de gêneros mais familiares a partir da proposição de uma situação comunicativa: "escrever um bilhete para transmitir um recado a alguém e/ou um convite para determinado evento". A partir dos $\mathbf{7 5 0}$ pontos de proficiência, os estudantes também já conseguem produzir uma história a partir de uma cena ou sequência de cenas (tirinha/história em quadrinhos) que apresentam: personagens praticando ações em uma sequência temporal; uso de articuladores, como marcadores temporais ("então", "depois"); uso de recursos coesivos, como pronomes, que contribuem para a continuidade temática do texto sem torná-lo repetitivo.

\section{$2^{\circ}$ ANO DO ENSINO FUNDAMENTAL}

\section{ABAIXO DO BÁSICO - até 500 pontos}

Os estudantes que se encontram no Padrão de Desempenho Abaixo do Básico desenvolveram habilidades muito iniciais do processo de aprendizagem da língua escrita. As crianças até $\mathbf{3 0 0}$ pontos, ao realizarem a cópia de um texto em uma página de caderno, ainda não consideram a ordem convencional de organização 
do texto na página, não respeitando as margens nem a sequência das palavras no texto, sem realizar adequadamente a passagem de uma linha para outra do texto/caderno. As crianças com proficiência entre 300 pontos e 400 realizam a cópia de um texto, observando algumas regras de utilização da página, embora possam não observar os limites das margens ou a necessidade de recomeçar a escrita na margem esquerda na passagem de uma linha a outra do texto/caderno. Os estudantes cuja proficiência encontra-se alocada no intervalo de 400 a 500 pontos apresentam uma escrita que pode ser, em alguns casos, ainda silábicoalfabética e, em outros, alfabética, escrevendo palavras de diferentes extensões e padrões silábicos - CV, VC, CVC, CVV - em conformidade com essas hipóteses de escrita. Isso significa que podem usar apenas uma letra para representar cada sílaba da palavra ou, ainda, que podem utilizar ora uma letra para cada sílaba, ora uma letra para cada som da palavra.

\section{BÁSICO - de 500 a 600 pontos}

As crianças que se encontram no Padrão de Desempenho Básico desenvolveram todas as habilidades de leitura e escrita descritas no Padrão de Desempenho Abaixo do Básico, apresentando uma escrita que pode ser, em alguns casos, silábico-alfabética e, em outros, alfabética. Esses estudantes escrevem palavras de diferentes extensões e padrões silábicos - CV, VC, CVC, CVV - em conformidade com as hipóteses anteriormente referidas. Uma conquista importante dos estudantes que apresentam este nível de proficiência é a habilidade de usar a página adequadamente, respeitando margens e a sequência adequada das palavras, inclusive quando há mudança de linha. Elas também produzem uma escrita alfabética de palavras de diferentes extensões e formadas por padrões silábicos variados: $\mathrm{CV}, \mathrm{VC}, \mathrm{CVC}, \mathrm{CVV}, \mathrm{CVCC}, \mathrm{CCVC}$.

\section{PROFICIENTE - de 600 a 700 pontos}

Os estudantes com proficiência alocada no Padrão de Desempenho Proficiente desenvolveram outras habilidades de escrita além daquelas descritas nos padrões anteriores, o que amplia as possibilidades de interação com os textos como escritores. As crianças com até $\mathbf{6 5 0}$ pontos de proficiência começam, a partir de um ditado, a escrever frases curtas, no padrão sintático sujeito/verbo/complemento, com ou sem espaçamento correto entre as palavras. No caso de frases não ditadas, produzidas a partir de uma gravura, inicia-se o desenvolvimento da habilidade de escrevê-las, ainda que no padrão de escrita silábico-alfabético, com ou sem uso de pontuação e de letras maiúsculas no início das frases. No intervalo entre 650 e 700 pontos na Escala de Proficiência, os estudantes demonstram ganhos significativos quanto à escrita. Observa-se, pois o início de uma transição de uma escrita alfabética de palavras para uma escrita com observância de algumas regras ortográficas, especialmente as contextuais: uso de "l" ou "u" em final de palavra; uso de "ss", "ç" ou "c", dentre outras. Os estudantes escrevem, ainda, palavras com dígrafos, marcas de nasalização e irregularidades ortográficas como o uso de "s"/“z"; "s"/“c"; "x"/“ch"; "g"/"j"; "ss"/"ç". Esses estudantes encontram-se no limiar entre o padrão Proficiente e o Avançado.

\section{AVANÇADO - Acima de 700 pontos}


Nesse Padrão de Desempenho são observados avanços significativos na escrita das crianças cuja proficiência se posiciona a partir de $\mathbf{7 0 0}$ pontos na Escala de Proficiência. Observa-se, por exemplo, a transição de uma escrita alfabética de palavras para uma escrita com observância de algumas regras ortográficas, especialmente as contextuais, como o uso de "l" ou "u" em final de palavra, uso de "ss", "ç" ou "c", dentre outras. Os estudantes escrevem, ainda, palavras com dígrafos, marcas de nasalização e irregularidades ortográficas como o uso de "s"/"z"; "s"/“c"; "x"/“ch"; "g"/"j"; "ss"/“ç". No caso da escrita de frases ditadas, observa-se, na maioria dos casos, o uso de espaçamento entre palavras, o que não acontece com regularidade quando se trata da escrita de frases a partir de imagens. Nesse caso, observa-se a plausibilidade da frase escrita em relação à cena apresentada, embora possam apresentar equívocos ortográficos decorrentes da semelhança entre os modos de articulação de alguns fonemas (transcrição da fala para a escrita). Esses equívocos também ocorrem no caso da escrita de frases ditadas. Nesse padrão, tem início o desenvolvimento de habilidades necessárias à produção de uma escrita ortográfica: observância de regras que orientam o uso de letras que podem representar um mesmo som em diferentes contextos; uso adequado de marcas de nasalização; uso de letras que podem representar um mesmo som em contextos semelhantes. Além disso, os estudantes começam a desenvolver a habilidade de produzir textos de gêneros mais familiares a partir da proposição de uma situação comunicativa: "escrever um bilhete para transmitir um recado a alguém e/ou um convite para determinado evento". Acrescenta-se a isso a elaboração de uma história a partir de uma cena (ou sequência de cenas) com o uso de elementos essenciais da narrativa como: personagens praticando ações em uma sequência temporal; uso de articuladores, como marcadores temporais; uso de recursos coesivos, como pronomes, que contribuem para a continuidade temática do texto sem torná-lo repetitivo.

\section{$3^{\circ}$ ANO DO ENSINO FUNDAMENTAL}

\section{ABAIXO DO BÁSICO - Até 600 pontos}

Os estudantes que se encontram nos níveis iniciais deste Padrão de Desempenho começam a desenvolver habilidades relacionadas à apropriação do sistema de escrita. Essas habilidades dizem respeito tanto aos aspectos gráficos - distinção entre letras e outras formas de representação, como o desenho, por exemplo, e utilização adequada da página ao escrever - quanto sonoros (consciência fonológica). Dado o caráter inicial deste processo de apropriação, as habilidades de leitura e escrita são ainda incipientes neste Padrão. Os estudantes com proficiência entre 250 e 300 pontos, ao realizarem a cópia de um texto em uma página de caderno, ainda não consideram a ordem convencional de organização do texto na página, não respeitando as margens nem a sequência das palavras no texto e não realizando adequadamente a passagem de uma linha a outra do caderno. Estudantes com proficiência entre 300 e 450 pontos, ao realizarem a cópia de um texto já observam algumas regras de utilização da página, embora possam não observar os limites das margens ou a necessidade de recomeçar a escrita na margem esquerda na passagem de uma linha a outra do texto. $\mathrm{O}$ ganho significativo nesse intervalo de proficiência diz respeito ao fato de os estudantes iniciarem a escrita de palavras dissílabas, trissílabas, paroxítonas nos padrões silábicos CV, CVC e/ou CVV. Entretanto, ao realizarem tal escrita, o fazem a 
partir da hipótese silábica e/ou da hipótese silábico-alfabética. Isso significa que podem usar apenas uma letra para representar cada sílaba da palavra ou, ainda, que podem utilizar ora uma letra para cada sílaba, ora uma letra para cada som da palavra. As crianças que estão se aproximando do Padrão de Desempenho seguinte, entre 450 e 500 pontos, ampliam os padrões silábicos que são capazes de escrever, embora ainda de forma silábica e silábico-alfabética, para os padrões $\mathrm{CV}, \mathrm{CVC}, \mathrm{CVV}, \mathrm{V}$ e com ditongo.

As crianças com proficiência entre 500 e 550 pontos apresentam uma escrita que pode ser, em alguns casos, silábico-alfabética e, em outros, alfabética. Essas crianças escrevem palavras de diferentes extensões e padrões silábicos $-\mathrm{CV}, \mathrm{VC}$, CVC, CVV - em conformidade com as hipóteses anteriormente referidas. No intervalo compreendido entre 550 e 600 pontos na Escala de Proficiência, os estudantes demonstram a habilidade de usar a página adequadamente, respeitando margens e a sequência adequada das palavras, inclusive quando há mudança de linha e a habilidade de produzir uma escrita alfabética de palavras de diferentes extensões e formadas por padrões silábicos variados: CV, VC, CVC, CVV, CVCC, CCVC.

\section{BÁSICO - de 600 a 650 pontos}

Nesse Padrão de Desempenho, ampliam-se as habilidades relacionadas aos usos sociais da escrita, o que indica que os estudantes demonstram ter maior familiaridade para produzirem gêneros textuais diversos (lista, bilhete, narrativa, convite etc.). Os estudantes com proficiência alocada nesse padrão começam a escrever frases curtas, no padrão sintático sujeito/verbo/complemento, quando ditadas, que podem ou não conter espaçamento correto entre as palavras. No caso de frases não ditadas, produzidas a partir de uma imagem que serve como mote, inicia-se o desenvolvimento da habilidade de escrevê-las, ainda que no padrão de escrita silábico-alfabético, com ou sem uso de pontuação e de letras maiúsculas no início das frases.

\section{PROFICIENTE - de 650 a 750 pontos}

Estudantes com proficiência entre 650 e 700 pontos apresentam avanços significativos no que tange à competência escritora. Nesse intervalo, começa a haver a transição da escrita alfabética de palavras para uma escrita com observância de algumas regras ortográficas, especialmente as contextuais: uso de "l" ou "u" em final de palavra; uso de "ss", "ç" ou "c", dentre outras. Os estudantes também escrevem palavras com dígrafos, marcas de nasalização e irregularidades ortográficas como o uso de "s"/“z"; "s"/"c"; "x"/“ch"; "g"/“j"; "ss"/“ç". No caso da escrita de frases ditadas, os problemas de hipossegmentação, quando o alfabetizando junta uma palavra na outra em uma frase ou texto, já não ocorrem na maioria dos casos. No entanto, quando se trata da escrita de frases a partir de imagens, esse tipo de desvio ainda são recorrentes, mesmo com sequências plausíveis em relação à cena apresentada, embora possam aparecer equívocos ortográficos decorrentes da semelhança entre os modos de articulação de alguns sons (transcrição fala-escrita), assim como na escrita de frases ditadas também. Os estudantes proficientes iniciaram o desenvolvimento de habilidades necessárias à produção de uma escrita ortográfica, tais como a observância de regras que orientam o uso de letras que podem representar um mesmo som em diferentes contextos e o uso adequado de marcas de nasalização e letras que 
podem representar um mesmo som em contextos semelhantes. Além disso, os estudantes começam a desenvolver a habilidade de produzir textos de gêneros mais familiares a partir da proposição de uma situação comunicativa: bilhete e convite.

\section{AVANÇADO - Acima de 750 pontos}

Os estudantes que se encontram no Padrão de desempenho Avançado demonstram já terem desenvolvido todas as habilidades de escrita descritas nos demais padrões e iniciam o desenvolvimento da habilidade de produzir uma história a partir de uma cena ou sequência de cenas, com todos os principais elementos que compõem uma narrativa: personagens praticando ações em uma sequência temporal; uso de articuladores, como marcadores temporais ("então", "depois"); uso de recursos coesivos, como pronomes, que contribuem para a continuidade temática do texto sem torná-lo repetitivo. Essas crianças demonstram já terem desenvolvido as habilidades elementares exigidas de um estudante ao término do ciclo de alfabetização.

\section{ANEXO 3}

Variáveis que compuseram os modelos de regressão hierárquicos em cada ano escolar

\begin{tabular}{|c|c|c|}
\hline \multicolumn{3}{|c|}{$\begin{array}{c}\text { Variáveis que compuseram os modelos de regressão } \\
\text { hierárquicos em cada ano escolar }\end{array}$} \\
\hline $\begin{array}{l}\text { Variáveis das } \\
\text { modelagens }\end{array}$ & Itens de leitura $1^{\circ}$ ano & Itens de leitura $3^{\circ}$ ano \\
\hline ISE & $\begin{array}{l}\text { P1, P3, P4, P6, P8, P11, P15, P21, } \\
\text { P23, P28, P29, P34, P35, P36, P37, } \\
\text { P41, P45, P47, P51, P53, P54, P56, } \\
\text { P69, P79, P77 }\end{array}$ & $\begin{array}{l}\text { P1; P4; P6; P9;P10; P20; P22; P23; } \\
\text { P30; P32; P34; P38; P39; P46; P50; } \\
\text { P55; P57; P59 P64; P65; P66; P68; } \\
\text { P70; P72; P76; P78; P79 }\end{array}$ \\
\hline $\begin{array}{l}\text { ISE, Raça, } \\
\text { Sexo }\end{array}$ & P2; P10; P24; P25; P59 & $\begin{array}{l}\text { P2; P12; P25; P26; P41; P43; P48; P67; } \\
\text { P71; P73 }\end{array}$ \\
\hline ISE, Sexo & $\begin{array}{l}\text { P5; P7; P9; P12; P13; P17; P19; P26; } \\
\text { P27; P30; P31; P33; P39; P49; P50; } \\
\text { P60; P66; P70; P78 }\end{array}$ & $\begin{array}{l}\text { P3; P5; P14; P17; P27; P28; P29; P31; } \\
\text { P37; P45; P47; P49; P56; P69; P77; } \\
\text { P80 }\end{array}$ \\
\hline ISE, Raça & P16; P18; P20; P32; P40 & P7; P8; P21; P24; P40; P44; P52; P62 \\
\hline Raça & P14; P38; P52; P67 & P16 \\
\hline Sexo & P48; P63 & P11; P15; P18; P33; P35; P58; P75 \\
\hline Raça, Sexo & Nenhum item & P13; P19 \\
\hline $\begin{array}{c}\text { Sem } \\
\text { significância }\end{array}$ & $\begin{array}{l}\text { P22; P42; P43; P44; P46; P55; P57; } \\
\text { P58; P61; P62; P64; P65; P68;P71; } \\
\text { P72; P73; P74; P75; P76; P80 }\end{array}$ & $\begin{array}{l}\text { P36; P42; P51; P53; P54; P60; P61; } \\
\text { P63; P74 }\end{array}$ \\
\hline
\end{tabular}




\section{ANEXO 4}

\begin{tabular}{|c|c|c|c|c|c|c|c|c|c|c|c|c|c|c|c|c|c|}
\hline \multicolumn{18}{|c|}{ Evolução do desempenho médio por turma em leitura e escrita } \\
\hline \multirow[b]{2}{*}{ Escola } & \multirow[b]{2}{*}{ Turma } & \multicolumn{8}{|c|}{ Proficiência em Leitura } & \multicolumn{8}{|c|}{ Proficiência em Escrita } \\
\hline & & Av 1 & $\begin{array}{c}\text { Nível de } \\
\text { desempenho }\end{array}$ & Av 2 & $\begin{array}{c}\text { Nível de } \\
\text { desempenho }\end{array}$ & Av 3 & $\begin{array}{c}\text { Nível de } \\
\text { desempenho }\end{array}$ & Av 4 & $\begin{array}{c}\text { Nível de } \\
\text { desempenho }\end{array}$ & Av 1 & $\begin{array}{c}\text { Nível de } \\
\text { desempenho }\end{array}$ & Av 2 & $\begin{array}{c}\text { Nível de } \\
\text { desempenho }\end{array}$ & Av 3 & $\begin{array}{c}\text { Nível de } \\
\text { desempenho }\end{array}$ & Av 4 & $\begin{array}{l}\text { Nível de } \\
\text { desempenho }\end{array}$ \\
\hline Tulipa & 10 ano $\mathrm{A}$ & 325,2 & $\begin{array}{c}\text { Abaixo do } \\
\text { básico }\end{array}$ & 514,92 & Proficiente & 602,11 & Proficiente & 589,46 & $\begin{array}{c}\text { Abaixo do } \\
\text { básico }\end{array}$ & 384,2 & $\begin{array}{c}\text { Abaixo do } \\
\text { básico }\end{array}$ & 580 & Proficiente & 677,26 & Proficiente & 645,58 & Básico \\
\hline Tulipa & 1o ano B & 409,4 & Básico & 558,47 & Proficiente & 643,27 & Proficiente & 744,37 & Proficiente & 422,7 & Básico & 534,73 & Proficiente & 728,71 & Avançado & 705,44 & Proficiente \\
\hline Tulipa & 10 ano $\mathrm{C}$ & 368,69 & $\begin{array}{l}\text { Abaixo do } \\
\text { básico }\end{array}$ & 522,39 & Proficiente & 680,13 & Proficiente & 760,45 & Avançado & 357,23 & $\begin{array}{c}\text { Abaixo do } \\
\text { básico }\end{array}$ & 590,67 & Proficiente & 641,8 & Proficiente & 641,03 & Básico \\
\hline Tulipa & 10 ano D & 479,84 & Básico & 633,34 & Avançado & 504,85 & Básico & 756,71 & Avançado & 404,16 & Básico & 562,61 & Proficiente & 549,55 & Básico & 713,12 & Proficiente \\
\hline \multirow[b]{2}{*}{ Escola } & \multirow[b]{2}{*}{ Turma } & \multicolumn{7}{|c|}{ Proficiência em Leitura } & & \multicolumn{7}{|c|}{ Proficiência em Escrita } & \\
\hline & & Av 1 & $\begin{array}{c}\text { Nível de } \\
\text { desempenho }\end{array}$ & Av 2 & $\begin{array}{c}\text { Nível de } \\
\text { desempenho }\end{array}$ & Av 3 & $\begin{array}{c}\text { Nível de } \\
\text { desempenho }\end{array}$ & Av 4 & $\begin{array}{c}\text { Nível de } \\
\text { desempenho }\end{array}$ & Av 1 & $\begin{array}{l}\text { Nível de } \\
\text { desempenho }\end{array}$ & Av 2 & $\begin{array}{c}\text { Nível de } \\
\text { desempenho }\end{array}$ & Av 3 & $\begin{array}{c}\text { Nível de } \\
\text { desempenho }\end{array}$ & Av 4 & $\begin{array}{c}\text { Nível de } \\
\text { desempenho }\end{array}$ \\
\hline Rosa & 10 ano $\mathrm{A}$ & 583,3 & Proficiente & 677,59 & Avançado & 606,4 & Proficiente & 710,73 & Proficiente & 330,19 & $\begin{array}{c}\text { Abaixo do } \\
\text { básico }\end{array}$ & 533,28 & Proficiente & 550,82 & Básico & 628,39 & Básico \\
\hline Rosa & 1o ano B & 699,98 & Avançado & 742,89 & Avançado & 773,65 & Avançado & 646,31 & Básico & 422,03 & Básico & 459,91 & Básico & 720,57 & Avançado & 669,68 & Proficiente \\
\hline \multirow[b]{2}{*}{ Escola } & \multirow[b]{2}{*}{ Turma } & \multicolumn{7}{|c|}{ Proficiência em Leitura } & & \multicolumn{7}{|c|}{ Proficiência em Escrita } & \\
\hline & & Av 1 & $\begin{array}{c}\text { Nível de } \\
\text { desempenho }\end{array}$ & Av 2 & $\begin{array}{c}\text { Nível de } \\
\text { desempenho }\end{array}$ & Av 3 & $\begin{array}{c}\text { Nível de } \\
\text { desempenho }\end{array}$ & Av 4 & $\begin{array}{c}\text { Nível de } \\
\text { desempenho }\end{array}$ & Av 1 & $\begin{array}{c}\text { Nível de } \\
\text { desempenho }\end{array}$ & Av 2 & $\begin{array}{c}\text { Nível de } \\
\text { desempenho }\end{array}$ & Av 3 & $\begin{array}{c}\text { Nível de } \\
\text { desempenho }\end{array}$ & Av 4 & $\begin{array}{l}\text { Nível de } \\
\text { desempenho }\end{array}$ \\
\hline Girassol & I & 598,27 & Proficiente & 656,09 & Avançado & 654,8 & Proficiente & 736,1 & Proficiente & 607,23 & Avançado & 668,35 & Avançado & 730,9 & Avançado & 755,85 & Avançado \\
\hline Girassol & II & 468,77 & Básico & 562,95 & Proficiente & 624,77 & Proficiente & 711,69 & Proficiente & 504,07 & Proficiente & 633,54 & Avançado & 696,87 & Proficiente & 748,45 & Proficiente \\
\hline
\end{tabular}




\begin{tabular}{|c|c|c|c|c|c|c|c|c|c|c|c|c|c|c|c|c|c|}
\hline \multirow{3}{*}{\begin{tabular}{|l|} 
Girassol \\
Girassol \\
\end{tabular}} & III & 533,05 & Proficiente & 629,49 & Avançado & \begin{tabular}{|l|}
$\mid 689,1$ \\
\end{tabular} & Proficiente & 759,19 & Avançado & 567,22 & Proficiente & 681,88 & Avançado & 726,72 & Avançado & $\mid 793,72$ & \multirow{2}{*}{$\begin{array}{c}\text { Avançado } \\
\text { Avançado }\end{array}$} \\
\hline & IV & 473,64 & Básico & 563,93 & Proficiente & 655,27 & Proficiente & 762,25 & Avançado & 518,91 & Proficiente & 615,02 & Avançado & 731,26 & Avançado & \begin{tabular}{|l|l|}
756,44 \\
\end{tabular} & \\
\hline & \multirow[b]{2}{*}{ Turma } & \multicolumn{7}{|c|}{ Proficiência em Leitura } & & \multicolumn{7}{|c|}{ Proficiência em Escrita } & \\
\hline Escola & & Av 1 & $\begin{array}{c}\text { Nível de } \\
\text { desempenho }\end{array}$ & $\mathrm{Av} 2$ & $\begin{array}{c}\text { Nível de } \\
\text { desempenho }\end{array}$ & Av 3 & $\begin{array}{c}\text { Nível de } \\
\text { desempenho }\end{array}$ & Av 4 & $\begin{array}{c}\text { Nível de } \\
\text { desempenho }\end{array}$ & Av 1 & $\begin{array}{c}\text { Nível de } \\
\text { desempenho }\end{array}$ & Av 2 & $\begin{array}{c}\text { Nível de } \\
\text { desempenho }\end{array}$ & Av 3 & $\begin{array}{c}\text { Nível de } \\
\text { desempenho }\end{array}$ & Av 4 & $\begin{array}{c}\text { Nível de } \\
\text { desempenho }\end{array}$ \\
\hline Lírio & $1^{\circ}$ ano 1 & 417,8 & Básico & 470,89 & Básico & 590,36 & Básico & 728,72 & Proficiente & 392,67 & $\begin{array}{l}\text { Abaixo do } \\
\text { básico }\end{array}$ & 615,42 & Avançado & 663,59 & Proficiente & 749,21 & Proficiente \\
\hline Lírio & $1^{\circ}$ ano 2 & 358,51 & $\begin{array}{c}\text { Abaixo do } \\
\text { básico } \\
\end{array}$ & 462,5 & Básico & 609,38 & Proficiente & 680,7 & Proficiente & 381,77 & $\begin{array}{c}\text { Abaixo do } \\
\text { básico }\end{array}$ & 588,09 & Proficiente & 688,52 & Proficiente & 710,69 & Proficiente \\
\hline Lírio & $1^{\circ}$ ano 3 & 405,8 & Básico & 529,57 & Proficiente & 617,32 & Proficiente & 694,3 & Proficiente & 425,84 & Básico & 576,34 & Proficiente & 685,29 & Proficiente & 716,27 & Proficiente \\
\hline Lírio & $1^{\circ}$ ano 4 & 409,87 & Básico & 508,37 & Proficiente & \begin{tabular}{|l|l|}
625,92 \\
\end{tabular} & Proficiente & 681,56 & Proficiente & 429,18 & Básico & 571,02 & Proficiente & 698,93 & Proficiente & 735,39 & Proficiente \\
\hline Lírio & $1^{\circ}$ ano 5 & 421,76 & Básico & 533,32 & Proficiente & 610,37 & Proficiente & & & 414,33 & & 604,04 & Avançado & 704,27 & Avançado & & \\
\hline
\end{tabular}




\section{ANEXO 5}

\section{Pauta de Observação de Campo}

Objetivo: Observação de conteúdos, sequência, tempo, clima didático e manejo de grupo, apoio ao desenvolvimento afetivo e social, cognitivo e verbal.

Nome do pesquisador (a):

Nome da Escola:

No da Turma

Série/Ano

Nome da

professora

\section{Pauta para observação de sala de aula}

\section{Parte A - Aspectos preliminares da sala e dos atores sociais diretamente envolvidos}

1. Dia/mês/ano: 2. Horário de Início da observação:

3. Horário de término da observação:

4. No. de alunos matriculados na turma: sendo: 5. Masc (__ $)$ 6. Fem (_ $)$

7. No. de alunos presentes: sendo: 8. Masc ) $9 . \mathrm{Fem}(\ldots)$

10. No. de alunos que chegaram após iniciada a aula:

11. Características gerais dos alunos:

(Descrever aspectos relacionados às características gerais das crianças: uso de uniforme, posse e estado de apresentação de materiais escolares, presença na turma de crianças com necessidades especiais. Outros aspectos relevantes que queira mencionar)

12. Características gerais do(a) professor(a): Sexo: ( ) F ( ) M

$\mathrm{O}$ (a) mesmo(a) professor(a) acompanha a turma desde o ano anterior: 13. Sim ( ) 14. Não ( ) 
15. Descrever aspectos relativos às características gerais do(a) professor(a): gestos, tom de voz, ânimo, organização pessoal etc.

\section{Parte B - Aspectos organizacionais ou de gestão da sala de aula}

1) Tempo real de ensino-aprendizagem
a) Início oficial:
c) Término oficial:
b) Início efetivo da aula (*):
d) Término efetivo:
(*) Por início efetivo, considerar atividades como: professora coloca a data no quadro negro, verifica a realização de deveres, começa a explicar matéria, pede aos alunos que abram o livro na página tal etc. Desconsiderar, portanto, o recolhimento de merendeiras, momento inicial em que as crianças ficam sem atividade em sala de aula enquanto a professora se mostra ocupada com outros afazeres (atender alguém na porta, fazer anotações etc).
2) O professor(a) se ausenta da sala? ( ) $\operatorname{sim} /$ ( ) não - Se sim, quantas vezes?

\section{3) Organização da rotina}
O professor inicia a aula fazendo um planejamento do uso do tempo com os alunos, ou seja, definindo tarefas, explicitando prioridades e/ou fazendo/rememorando combinados com o grupo)? ( ) sim / ( ) não.
Observações:

e) No. de interrupções:

f) Tempo real total:

4) Organização espacial da classe: na maior parte do tempo observado, os alunos permaneceram organizados em:

(a) fileiras individuais; (b) duplas; (c) pequenos grupos (3-4 membros); (d) grandes grupos (acima de 5 membros); (e) outras configurações/observações complementares: 
5) Rituais de início da aula (marcar todas as opções que se fizerem presentes durante a observação):

O professor...

a) Recolhe ou verifica a agenda

b) Faz a chamada ou preenche a lista de presença

c) Verifica a realização de deveres de casa

d) Escolhe o(a) aluno(a) ajudante do dia

e) Distribui materiais de uso coletivo

f) Certifica-se se todos os alunos estão de posse dos materiais didáticos necessários à realização da atividade

g) Outros

\section{Parte C - Atividades didáticas ou situações de ensino-aprendizagem}

1) Com respeito à forma como o(a) professor(a) propõe os temas / atividades de aula, registre no quadro abaixo a(s) ocorrência(s) das seguintes situações:

\section{$\mathrm{O}$ (a) professor(a)...}

a) Apresenta ou retoma os temas em pauta?

b) Explica o que os alunos deveriam aprender nesta aula?

c) Anuncia as atividades que os alunos irão realizar na aula?

d) Faz perguntas/propõe desafios para introduzir os conteúdos?

e) Explora experiências ou saberes dos alunos a respeito do tema e das atividades em desenvolvimento?

f) Relaciona o tema da aula com situações práticas cotidianas?

g) Relaciona o tema ou atividade com conhecimentos/saberes prévios?

1.1) Além das situações acima, o(a) professor(a) faz uso de outras estratégias para mobilizar/motivar os alunos para a aula? Quais?

\section{2) Sobre o desenvolvimento da aula:}


2.1) Descreva a sequência de atividades e temas tratados do início ao término da observação (Por ex: Matemática/Adição; Língua Portuguesa/Produção de texto; Ciências Naturais/Vertebrados; História e Geografia/Mapa )

\begin{tabular}{|l|l|}
\hline \multicolumn{1}{|c|}{ Atividades e temas de ensino } & $\begin{array}{c}\text { Tempo investido } \\
\text { (em minutos) }\end{array}$ \\
\hline a) & \\
\hline b) & \\
\hline c) & \\
\hline d) & \\
\hline e) & \\
\hline f) & \\
\hline g) & \\
\hline h) & \\
\hline i) & \\
\hline j) & \\
\hline k) & \\
\hline l) & \\
\hline
\end{tabular}

2.2) Assinale as estratégias metodológicas adotadas pelo(a) professor(a), destacando a seguir as 06 (seis) principais, conforme o quadro abaixo:

\begin{tabular}{|c|c|c|c|}
\hline \multirow[t]{2}{*}{$\begin{array}{l}\text { I - Estratégias metodológicas utilizadas pelo professor durante a } \\
\text { aula }\end{array}$} & \multicolumn{2}{|c|}{$\begin{array}{l}\text { Ocorreu na } \\
\text { aula? }\end{array}$} & \multirow{2}{*}{$\begin{array}{c}\text { As seis } \\
\text { Principais } \\
\text { neste bloco }\end{array}$} \\
\hline & Sim & Não & \\
\hline \multicolumn{4}{|l|}{ Estratégias metodológicas gerais } \\
\hline a) Faz perguntas aos alunos & & & \\
\hline b) Responde às perguntas dos alunos & & & \\
\hline c) Esclarece termos/conceitos & & & \\
\hline d) Usa o livro didático & & & \\
\hline $\begin{array}{l}\text { e) Realiza anotações no quadro (significados, resoluções, } \\
\text { instruções para as tarefas etc) }\end{array}$ & & & \\
\hline $\begin{array}{l}\text { f) Revisa pontos anteriores do conteúdo quando algum aluno } \\
\text { apresenta dificuldade com a matéria atual }\end{array}$ & & & \\
\hline g) Distribui fichas extras com tarefas e exercícios & & & \\
\hline $\begin{array}{l}\text { h) Utiliza TV/Vídeo ou computador para trabalhar conteúdos } \\
\text { relacionados ao tema em estudo }\end{array}$ & & & \\
\hline i) Dá aos alunos instruções para o trabalho em grupo & & & \\
\hline $\begin{array}{l}\text { j) Propõe atividades diversificadas simultâneas ao longo da aula } \\
\text { para atender às especificidades dos grupos }\end{array}$ & & & \\
\hline
\end{tabular}

\begin{tabular}{|c|c|c|c|}
\hline \multirow[t]{2}{*}{$\begin{array}{l}\text { II - Estratégias metodológicas utilizadas pelo professor durante a } \\
\text { aula }\end{array}$} & \multicolumn{2}{|c|}{$\begin{array}{l}\text { Ocorreu na } \\
\text { aula? }\end{array}$} & \multirow{2}{*}{$\begin{array}{c}\text { As seis } \\
\text { Principais } \\
\text { neste bloco }\end{array}$} \\
\hline & Sim & Não & \\
\hline \multicolumn{4}{|l|}{ Estratégias metodológicas relacionadas à leitura } \\
\hline a) Lê em voz alta histórias ou outros textos para os alunos & & & \\
\hline b) Conta histórias para os alunos & & & \\
\hline
\end{tabular}




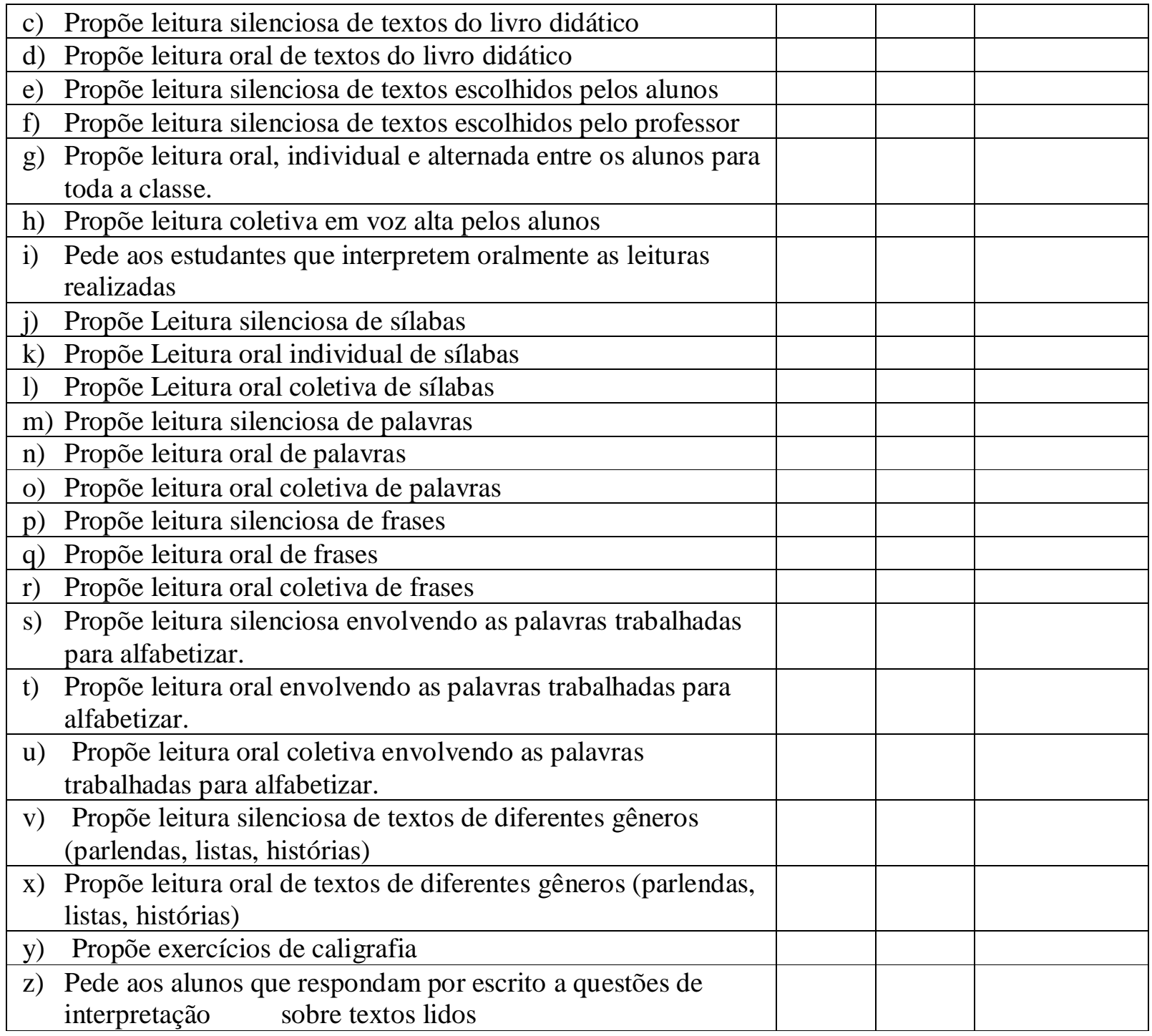

\begin{tabular}{|c|c|c|c|}
\hline \multirow[t]{2}{*}{$\begin{array}{l}\text { III - Estratégias metodológicas utilizadas pelo professor durante a } \\
\text { aula }\end{array}$} & \multicolumn{2}{|c|}{$\begin{array}{l}\text { Ocorreu na } \\
\text { sala? }\end{array}$} & \multirow{2}{*}{$\begin{array}{c}\text { As seis } \\
\text { Principais } \\
\text { em cada } \\
\text { bloco }\end{array}$} \\
\hline & Sim & Não & \\
\hline \multicolumn{4}{|l|}{ Estratégias metodológicas relacionadas à escrita } \\
\hline a) Propõe cópia para reforçar uma aprendizagem. & & & \\
\hline b) Propõe cópia para auxiliar na memorização. & & & \\
\hline c) Propõe cópia para a realização de uma atividade. & & & \\
\hline d) Propõe cópia de enunciados ou questões propostas no quadro. & & & \\
\hline $\begin{array}{l}\text { e) Propõe cópia de enunciados ou questões propostas no livro } \\
\text { didático. }\end{array}$ & & & \\
\hline f) Propõe ditado de palavras & & & \\
\hline g) Propõe ditado de frases & & & \\
\hline h) Propõe ditado de textos & & & \\
\hline i) Propõe escrita de palavras com apoio de imagem. & & & \\
\hline
\end{tabular}




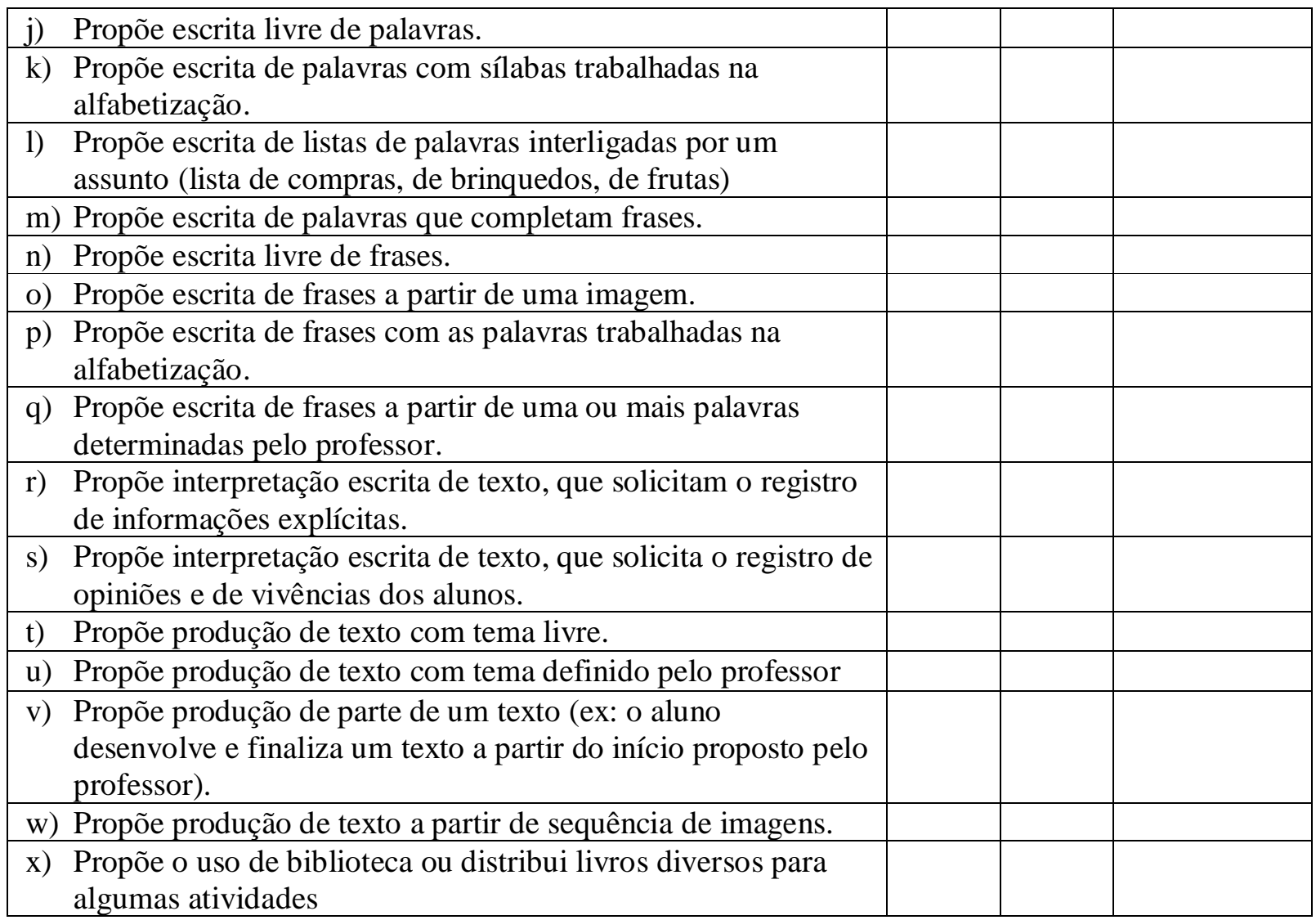

\begin{tabular}{|c|c|c|c|}
\hline \multirow[t]{2}{*}{$\begin{array}{l}\text { IV - Estratégias metodológicas utilizadas pelo professor durante a } \\
\text { aula }\end{array}$} & \multicolumn{2}{|c|}{$\begin{array}{l}\text { Ocorreu na } \\
\text { sala? }\end{array}$} & \multirow{2}{*}{$\begin{array}{c}\text { As seis } \\
\text { Principais } \\
\text { em cada } \\
\text { bloco }\end{array}$} \\
\hline & Sim & Não & \\
\hline \multicolumn{4}{|l|}{$\begin{array}{l}\text { Estratégias metodológicas relacionadas ao ensino da } \\
\text { matemática }\end{array}$} \\
\hline a) Explica os exercícios de matemática no quadro & & & \\
\hline b) Propõe que faça exercícios do livro didático & & & \\
\hline $\begin{array}{l}\text { c) Debate com os alunos as estratégias de resolução de } \\
\text { problemas }\end{array}$ & & & \\
\hline d) Chama os alunos no quadro para resolver os exercícios & & & \\
\hline $\begin{array}{l}\text { e) Utiliza-se de materiais complementares como material } \\
\text { dourado/material multibase? }\end{array}$ & & & \\
\hline $\begin{array}{l}\text { f) Constrói ou interpreta com os alunos tabelas, gráficos ou } \\
\text { outros registros de tratamento da informação? }\end{array}$ & & & \\
\hline $\begin{array}{l}\text { g) Usa jogos ou outros materiais concretos de apoio ao } \\
\text { ensino da matemática (ábaco, tangran, etc.) }\end{array}$ & & & \\
\hline h) Usa o computador para apoiar o ensino da matemática & & & \\
\hline
\end{tabular}

2.3) Quanto ao uso de materiais em aula, registrar abaixo todos os que foram efetivamente utilizados durante o período observado. Para tanto, utilize-se das 
colunas da direita para anotar se tal uso se deu com ajuda/orientação do professor na situação de aprendizagem ou enquanto o mesmo se ocupava com outras atividades (correção de cadernos, anotações em agenda ou diários de classe, etc).

\begin{tabular}{|l|l|l|}
\hline Materiais & Com professor & $\begin{array}{c}\text { Sem } \\
\text { professor }\end{array}$ \\
\hline a) Biblioteca de sala (“cantinho de leitura”) & & \\
\hline b)Calculadoras & & \\
\hline c) Cartilha & & \\
\hline d)Computadores & & \\
\hline e) Diagramas e representações de corpo humano & & \\
\hline f) Instrumentos musicais & & \\
\hline g) Jogos pedagógicos (tangran, ábaco, outros) & & \\
\hline h)Lápis e papéis coloridos, tesoura, cola & & \\
\hline i) Livro Didático & & \\
\hline j) Mapas, Globos, Atlas & & \\
\hline k) Materiais de geometria & & \\
\hline $\begin{array}{l}\text { 1) Materiais diversificados de leitura: outros livros, revistas, } \\
\text { dicionários, enciclopédia, jornais, etc. }\end{array}$ & & \\
\hline m) Material audiovisual (retroprojetor/ “datashow”) & & \\
\hline $\begin{array}{l}\text { n) Material Dourado ou Multibase (placas de madeiras para apoio } \\
\text { operações) }\end{array}$ & & \\
\hline o) Terrário, aquário & & \\
\hline p)TV/Vídeo/DVD & & \\
\hline
\end{tabular}

\section{Encerramento da aula}

3.1) Marque todos os aspectos que correspondam à realidade observada

O professor...

a) Recupera o sentido do que foi realizado em aula naquele dia?

b) Avalia com os alunos as atividades realizadas e os resultados obtidos?

c) Relaciona as aprendizagens com os objetivos da aula?

d) Assinala os temas que ficaram pendentes?

e) Passa deveres para casa?

f) Relaciona a produção do dia com os materiais e atividades que serão feitas nas aulas seguintes?

g) Pede aos alunos para organizarem o espaço antes de saírem e guardar os materiais utilizados?

h) O final da aula guarda relação com as atividades realizadas durante aquele dia?

i) Não se evidencia um final

j) Outras situações: descrever

Parte D - Ambiente ou clima escolar e aspectos ligados ao desenvolvimento afetivo-social dos alunos 
1) Na sala de aula registra-se a existência de normas/regras/combinados afixados em local visível? ( ) sim ( ) não Em caso positivo, como se dá o cumprimento/uso dessas regras? Os alunos fazem menção à elas? Regulam suas condutas pelos combinados? Comentários:

2) Em relação ao clima da sala de aula / manejo grupal observado, é correto afirmar:

\section{$\mathrm{O}$ (a) professor(a)...}

a) Parece "fazer questão" de que todos os alunos aprendam, mesmo os que demonstram mais dificuldade;

b) Permite algum nível de conversa entre as crianças;

c) Adapta a disposição da sala às atividades quando necessário;

d) Mantém os alunos envolvidos com as tarefas propostas;

e) Supervisiona e se mantém atento aos pedidos/necessidades de ajuda aos alunos;

f) Intervém em situações de indisciplina ou conflito entre os alunos, sem fazer uso de "discursos" ou "castigos" exagerados;

g) Mantém os alunos produtivamente ocupados a maior parte do tempo.

h) Outras observações

3) Em relação ao apoio prestado pelo(a) professor(a) ao desenvolvimento afetivo-social dos alunos, é correto afirmar:

\section{$\mathrm{O}$ (a) professor(a)...}

a) Tem uma "tonalidade afetiva" geralmente positiva;

b) Demonstra afeto pelos alunos;

c) Recebe com agrado as manifestações de afeto dos alunos;

d) Estimula a cooperação e a generosidade entre as crianças;

e) Favorece o respeito mútuo (não permite os deboches/apelidos);

f) Não coloca "rótulos" nas crianças;

g) Não as sanciona publicamente;

h) Estimula que as crianças se ensinem mutuamente;

i) Se refere aos alunos por seus nomes próprios;

j) Valoriza as qualidades pessoais de cada aluno;

4) Em relação ao apoio prestado pelo(a) professor(a) ao desenvolvimento cognitivo e verbal, é correto afirmar:

$\mathrm{O}$ (a) professor(a)...

a) Responde adequadamente às perguntas ou solicitações dos alunos;

b) Cria situações favorecedoras do desenvolvimento da oralidade, abrindo 
espaços para relatos, descrições, comparações, associações entre situações distintas, etc;

c) Procura aproximar as atividades de desenvolvimento da linguagem escrita ao seu uso social;

d) Utiliza os erros das crianças como oportunidade de aprendizagem;

e) Contextualiza adequadamente as aprendizagens;

f) Formula perguntas abertas aos alunos;

g) Escuta ativamente as crianças;

h) Dá aos alunos o tempo necessário para que se expressem/ se comuniquem adequadamente;

i) Recoloca de forma correta as mensagens confusas, incompletas ou errôneas;

j) Valoriza e amplia os comentários dos alunos;

k) O professor faz bom uso da linguagem oral e escrita (se comunica bem/fala corretamente).

5) Em relação ao apoio prestado pelo(a) professor(a) ao desenvolvimento da postura autônoma dos alunos e formação de hábitos de estudos, é correto afirmar:

O professor(a)...

a) $\mathrm{O}$ (a) professor(a) valorizou as possíveis contribuições trazidas de casa pelos alunos para enriquecer os temas em estudo;

b) Orientou a utilização de agendas;

c) c) Orientou a organização material dos alunos;

d) c) Orientou a produção de anotações pessoais em cadernos;

e) Criou espaço na aula para que os alunos debatessem eventuais problemas e buscassem de forma compartilhada possíveis soluções para os mesmos;

f) Incentivou/aproveitou sugestões e opiniões sobre questões ligadas aos temas em estudo ou andamento dos trabalhos;

g) Mostrou preocupação em ensinar aos alunos, além dos conteúdos específicos das diferentes disciplinas, a estudarem autonomamente ou a aprimorarem estratégias de estudo já consolidadas;

h) Deu espaço para que cada aluno refletisse sobre os seus resultados e estabelecesse metas pessoais para as próximas etapas de estudo.

6) Em relação à reação dos alunos frente a apresentação dos temas, atividades e instruções do(a) professor(a), selecione apenas o item que expresse a postura predominante na maioria da turma:

\section{1) Frente a propostas e tentativas de mobilização/motivação do(a) professor(a), os alunos:}

a) Respondem ativamente as perguntas e mostram-se entusiasmados;

b) Propõem direta ou indiretamente outros temas de seu interesse;

c) Aceitam com passividade as propostas do(a) professor(a);

d) Interrompem com comentários e perguntas impróprias;

e) Não mostram interesse pelo tema proposto

6.2) Frente às instruções do(a) professor(a), os alunos:

a) As ignoram

b) As acatam realizando a tarefa sem muito empenho; 
c) As seguem com dificuldade (consultam o/a professor/a reiteradamente).

d) As seguem com facilidade e "soltura";

6.3) Sobre a interação entre alunos, se:

a) Se apoiam mutuamente por meio de instruções e explicações;

b) Fazem brincadeiras e deboches entre si;

c) Brigam e mostram conflitos pessoais entre si;

d) Se corrigem e se disciplinam mutuamente;

e) Competem entre si por resultados

f) Escutam com atenção e se interessam pelo trabalho de seus companheiros;

g) Ignoram o trabalho de seus companheiros.

6.4) Quanto à disciplina:

a) Mais da metade dos alunos permanece atenta, acompanhando as aulas e perguntando ou opinando;

b) Mais da metade dos alunos permanece atenta, mas apenas alguns perguntam ou opinam;

c) Apenas um grupo pergunta ou opina, enquanto os demais fazem bagunça ou se desligam do trabalho em sala.

d) Nenhum aluno pergunta ou opina

Nome legível do(a) pesquisador(a)

\section{ANEXO 6 \\ Roteiro de Entrevistas}

\section{DIREÇÃO}




\section{Roteiro de entrevista individual Direção}

Nome da Escola:

Nome do (a) Diretor (a):

\section{Fatores que influenciam nos resultados da escola}

a) Há quanto tempo esta escola existe?

b) Qual a sua opinião sobre os fatores que influenciam nos resultados obtidos pelos alunos da sua escola?

c) Dentre esses fatores, quais rituais ou práticas contribuem para dar uma "marca" ou "identidade" à essa escola?

\section{Objetivos e Metas da Escola:}

a) Quais objetivos educacionais orientam as ações nesse estabelecimento, ou seja, o que de mais importante a escola espera conseguir junto aos seus alunos?

b) A compreensão desse(s) objetivo(s) é compartilhada por todos os professores? Em quais fatos ou dados você se baseia para esta afirmação?

c) Pais e alunos também conhecem e concordam com este projeto?

d) A escola se colocou metas a atingir? Quantas/ quais? Estes objetivos e metas estão registradas em algum documento escolar?

e) Quais estratégias / iniciativas a escola desenvolve para realizar seus objetivos e metas? Algum projeto específico foi criado? Vocês tiveram apoio? De quem? Como?

f) Quais medidas concretas foram tomadas para garantir o cumprimento das metas? Elas estão sendo atingidas? Como é o processo de avaliação do cumprimento dessas metas? Quais os próximos passos?

g) Em relação ao IDEB, a escola vem atingindo as metas estabelecidas? Como a escola procura dar conta das metas do IDEB? Que estratégias são adotadas?

h) Como diretor (a) você sente a necessidade de maior autonomia para realizar a sua tarefa?

i) Em quais áreas a escola tem mais autonomia para tomar decisões: área pedagógica ou técnica ( ); gestão dos recursos humanos ( ); uso dos recursos para reformas e equipamentos ( ) ; outras ( ) especificar. Em sua opinião, esta autonomia influencia nos resultados da escola? ( ) $\operatorname{sim} /($ ) não, por quê?

j) Em relação à área pedagógica, esta escola segue um plano oficial para toda a rede ou tem o seu próprio projeto pedagógico?

k) Além das disciplinas regulares, nessa escola há atividades complementares ou extracurriculares? Se sim, quais? Como são propostas e efetivadas?

\section{Organização escolar}

a) Como se estrutura a equipe dirigente desta escola? (Procurar fazer o organograma, indicando responsabilidades, funções e tarefas)

b) Que instâncias de trabalho coletivo (formais ou informais) existem na escola? Sobre quais focos/temas atuam? Quem participa dessas instâncias? Com qual periodicidade estas instâncias se reúnem? Quanto tempo dura 
cada encontro de cada equipe? Quais desses grupos têm autonomia para tomar decisões?

c) Qual a sua carga horária de trabalho? Quais as principais tarefas que realiza e o tempo que dedica a cada uma delas?

d) Diante de ausência de professores, por doença ou outro inconveniente, quem os substituiu? Que tipos de atividades fazem as crianças nessas circunstâncias? No último mês, quantas ausências de professores foram registradas?

e) Que critérios são utilizados para formar as turmas? Quando há mais de uma turma por turno, quais os fatores que influenciam na composição das mesmas?

f) Nessa escola, quem define a alocação dos professores nas turmas? Que critérios orientam esta escolha? Como foram alocados os professores das turmas deste ano?

4. Docentes: Perfil e estratégias de orientação pedagógico-educacional

a) Nessa escola se estimula o professor a realizar sua prática dentro de algum enfoque metodológico ou abordagem específica de alfabetização ou cada um segue seu próprio método?

b) Qual o método ou abordagem predominante nessa escola? No que consiste este método? O que faz a escola para assegurar a realização de práticas pedagógicas dentro desse modelo?

c) Existem nessa escola orientações e critérios técnicopedagógicos/curriculares/de avaliação que devem ser seguidos e praticados por todos os professores? Quais são? Como é feita a supervisão pela equipe pedagógica?

d) Que apoio recebem os professores por parte da equipe pedagógica para o planejamento e preparo de suas aulas?

e) Nesta escola, faz parte das atribuições da direção e da coordenação entrar em sala de aula para observar o desempenho do professor? Se sim, com qual periodicidade? Como os dados observados são tratados com os professores?

f) Das $\mathrm{X}$ horas de aula lecionadas por semana, quantas horas são dedicadas, em média, para cada disciplina?

g) Como os professores são avaliados em suas práticas? Com base em que critérios estas avaliações são feitas? Quem tem acesso aos resultados dessas avaliações? Essas avaliações têm repercussão dentro da escola, ou seja, elas contribuem para melhorar as práticas docentes realizadas?

h) Neste ano, quais foram as prioridades das reuniões pedagógicas? Quais ações foram realizadas? Quais estratégias/ recursos foram utilizados? Quais temas foram abordados?

5. Clima organizacional: relacionamento interpessoal, participação e compromisso.

a) Como você qualificaria as relações interpessoais e o clima de trabalho dessa escola? (Sondar aspectos relativos à relação professor/aluno; professor/professor; professor/equipe de direção, etc. )

b) Em sua opinião, em relação a quais assuntos da escola é indispensável contar com a participação ativa dos professores? 
c) De um modo geral, como os professores lidam com solicitações da direção para atividades extra-aula (participação em festas, campanhas, reuniões ou outras atividades)?

6. Alunos: perfil e expectativas sobre seu desempenho e aprendizagem

a) Qual o perfil dos alunos dessa escola?

b) Quais critérios e regras regem a promoção desses alunos?

c) Do total de alunos matriculados no início do ensino fundamental $/$ médio, quantos, em média, chegam à última série atendida pela escola? (Anotar até que série a escola oferece)

d) Qual o perfil dos alunos que deixam a escola?

e) Que nível de ensino você acredita que a maioria de seus alunos alcançará no futuro? Por quê?

f) Em sua opinião, quais os fatores que poderão contribuir para isso, ou seja, qual poderá ser a capacidade de contribuição da escola e qual a influência dos fatores externos?

7. Relacionamento escola, família e comunidade

a) Qual o perfil das famílias dos alunos atendidos pela escola?

b) Em sua opinião, qual a influência dessas características familiares nos resultados obtidos pelos alunos?

c) Quais atividades a escola realiza para pais e outros responsáveis?

d) Há algum aspecto da cultura local que a escola tenta resgatar e integrar às suas práticas curriculares? Quais? Como isso é feito?

e) Pode-se afirmar a existência de um clima de colaboração e participação das famílias na escola? Quais são as ações concretas? Quais os projetos? Quais os resultados?

f) A escola realiza ou participa de alguma ação em parceria com a comunidade? Quem as promove? Quais são os objetivos? Existem outras entidades participando dessas ações junto com a escola?

g) Há fatores característicos do entorno comunitário que favorecem ou prejudicam os resultados obtidos na escola? Quais? De que forma esta influência se exerce?

8. Infra-estrutura pedagógica, materiais e equipamentos: posse e condições efetivas de uso

a) Quais os recursos pedagógicos disponíveis para os professores? Como se dá este uso? É regular/esporádico? São suficientes?

b) Nessa escola, como é realizado o processo de escolha dos livros didáticos e outros materiais? Esta estratégia de escolha tem tido, em sua opinião, efeito positivo sobre os resultados escolares?

9. Por fim, dentre os vários fatores que se relacionam aos resultados desta escola, quais são, em sua opinião, os que mais afetam positivamente e os que poderia representar um risco (ou ameaça)?

No final da entrevista agradecer ao entrevistado(a) e gravar também o nome do(a) entrevistador(a). 


\section{COORDENAÇÃO PEDAGÓGICA \\ Roteiro de entrevista}

\section{A - Identificação:}

1. Nome da Escola

2. Nome do(a) entrevistado(a)

3. Idade:

4. Formação:

a) Se Magistério, especificar ano de conclusão

b) Se Graduação, especificar curso e ano de conclusão.

c) Se Especialização (mín. 360 h) - Especificar modalidade e ano de conclusão

d) Se Pós-Graduação, especificar se mestrado ou doutorado, especificar título e ano de conclusão.

5. Tempo de atividade profissional

6. Tempo nessa escola

7. Carga horária semanal de trabalho

8. Principais tarefas que realiza e tempo que dedica a cada uma delas

\section{B. Equipe Técnica:}

1. Além de você, existem outros profissionais na equipe técnica? Se sim, quais as outras atividades realizadas pelos outros membros? Há quanto tempo trabalham juntos? Como você definiria o perfil dessa equipe?

2. Fatores de influência nos resultados escolares

a) Em sua opinião, quais são os fatores que influenciam nos resultados dessa escola?

b) Dentre esses fatores, quais rituais ou práticas contribuem para dar uma "marca" ou "identidade" a essa escola?

c) Você diria que direção, equipe técnica e professores colaboram para fazer esta escola funcionar bem, ou seja, a comunicação institucional é boa? As pessoas levam em consideração as idéias apresentadas pelos diferentes membros da escola?

d) Como é o estilo de decisão nessa escola? Há participação dos vários segmentos (Equipe, professores, pais)? Dê exemplo de situações vividas neste ano.

3. Objetivos e Metas da Escola:

a) Esta escola segue um plano oficial para toda a rede ou tem o seu próprio projeto pedagógico?

b) Se tiver projeto próprio, explicitar: como ele foi produzido? Em quanto tempo? Por quem? O que este plano tem que o caracteriza como um plano desta escola?

c) Quais objetivos educacionais orientam as ações nessa escola, ou seja, o que de mais importante a escola espera conseguir junto aos seus alunos? 
d) Você diria que esses objetivos são compartilhados por todos (direção, equipe técnica, professores, pais e alunos)? Em quais fatos ou dados se baseia a sua opinião?

e) A escola se colocou metas a atingir? Quais?

f) Estes objetivos ou metas estão registradas em algum documento escolar? (Se sim, ver possibilidade de fazer uma cópia para a pesquisa)

g) Quais estratégias / iniciativas a escola desenvolve para realizar seus objetivos e metas? Algum projeto específico foi criado? Vocês tiveram apoio? De quem? Como?

h) Que medidas concretas foram tomadas para garantir o cumprimento das metas?

i) Elas estão sendo atingidas? Como é o processo de avaliação do cumprimento dessas metas?

j) Quais os próximos passos?

k) Além das disciplinas regulares, nessa escola há atividades complementares ou extracurriculares? Se sim, quais? Como são propostas e efetivadas?

1) Em relação ao IDEB, a escola vem atingindo as metas estabelecidas? Como a escola procura dar conta das metas do IDEB? Que estratégias são adotadas?

4. Organização escolar

a) Quais instâncias de trabalho coletivo (formais ou informais) existem na escola? Sobre quais focos/temas atuam? Quem participa dessas instâncias? Com qual periodicidade estas instâncias se reúnem? Quanto tempo dura cada encontro de cada equipe? Quais desses grupos têm autonomia para tomar decisões?

b) Como coordenador (a) você sente a necessidade de maior autonomia para realizar a sua tarefa? Você poderia dar exemplos de situações vividas com mais ou menos autonomia?

c) Em sua opinião, esta autonomia influencia nos resultados da escola? ( ) sim / ( ) não, por quê?

d) Diante de ausência de professores, por doença ou outro inconveniente, quem os substituiu? Que tipo de atividades fazem as crianças nessas circunstâncias? No último mês, quantas ausências de professores foram registradas?

e) Que critérios são utilizados para alocar os alunos nas turmas? Quando há mais de uma turma por turno, quais os fatores que influenciam na composição das mesmas?

f) Nessa escola, quem define a alocação de professores nas turmas? Que critérios orientam estas escolhas?

5. Perfil do quadro docente e estratégias de orientação pedagógico-educacional

a) Como você descreve o corpo docente dessa escola em relação aos seguintes aspectos:

- Quantidade (suficiente? Falta professor em alguma área?)

- Formação e atualização 
- Tempo de casa e experiência

- Cumprimento formal de seus deveres (freqüência, pontualidade, produção de diários de classe, planejamentos, etc., cumprimento de prazos e combinados)

- Compromisso com a aprendizagem dos alunos

- Expectativas e nível de exigência acadêmica em relação aos alunos

- Disponibilidade para discutir/propor soluções para os problemas da escola

- Interesses corporativos (discussão sindical, político-partidária, etc)

b) Nessa escola se estimula o professor a realizar sua prática dentro de algum enfoque metodológico ou abordagem de alfabetização específica, ou cada um segue seu próprio método?

c) Caso a resposta anterior seja afirmativa: No que consiste este método? O que faz a escola para assegurar a realização de práticas pedagógicas dentro desse modelo?

d) Existem nessa escola orientações (curriculares, de avaliação, normas de comportamento ou outras) que devem ser respeitadas ou postas em prática por todos os professores? Quais são?

e) Como é feita a supervisão ao cumprimento dessas orientações pela equipe técnica?

f) Que apoio recebem os professores por parte da equipe técnica para planejamento e preparo de suas aulas?

g) Faz parte das atribuições da coordenação entrar em sala para observar o desempenho do professor? Se sim, com qual periodicidade? Como os dados observados são tratados com os professores? Quantas vezes você entrou em sala no último mês?

h) Das $\mathrm{X}$ horas de aula lecionadas por semana, quantas horas são dedicadas, em média, para cada disciplina?

i) Como os as práticas dos professores são avaliadas? Com base em quais critérios estas avaliações são feitas? Quem tem acesso aos resultados dessas avaliações? Em sua opinião, essas avaliações têm repercussão dentro da escola, ou seja, elas contribuem para melhorar as práticas docentes realizadas?

j) Quanto aos tempos dedicados para o Centro de Estudos, responda: Quais ações foram realizadas? Quais estratégias e recursos foram utilizados? Quais temas foram abordados? Em sua opinião, as atividades do Centro de Estudos foram produtivas, ou seja, geraram resultados observáveis em relação à prática docente?

k) Nessa escola se estimula que os professores trabalhem colaborativamente, troquem experiências, planejem juntos ou façam a reflexão sobre a própria prática? Dê exemplos de atividades realizadas com este intuito.

1) Os professores desta escola se esforçam para coordenar o conteúdo das matérias entre as diferentes séries?

m) Você sente os professores interessados/ empenhados em melhorar suas aulas? 
6. Infra-estrutura pedagógica, materiais e equipamentos: posse e condições efetivas de uso

a) Quais os recursos pedagógicos disponíveis para os professores? Como se dá este uso? É regular/esporádico? São suficientes?

b) Nessa escola, como se dá o processo de escolha dos livros didáticos e outros materiais? Esta estratégia de escolha tem tido, em sua opinião, efeito positivo sobre os resultados escolares?

7. Clima organizacional: relacionamento interpessoal, participação e compromisso

a) Como você qualificaria as relações interpessoais e o clima de trabalho dessa escola? (Sondar aspectos relativos à relação professor/aluno; professor/professor; professor/equipe de direção, etc. )

b) Em sua opinião, em quais assuntos da escola é indispensável contar com a participação ativa dos professores? Em quais não é necessário?

c) De um modo geral, como os professores lidam com solicitações da direção para atividades extra-aula (participação em festas, campanhas, reuniões ou outras atividades)?

8. Alunos: perfil e expectativas sobre seu desempenho e aprendizagem

a) Qual o perfil dos alunos dessa escola?

b) Quais critérios e regras regem a promoção desses alunos?

c) Do total de alunos matriculados no inicio do ensino fundamental/médio, quantos, em média, chegam à última série oferecida pela escola? (Anotar até qual série a escola atende)

d) Qual o perfil dos alunos que deixam a escola?

e) Que nível de ensino você acredita que a maioria de seus alunos alcançará no futuro? Por quê?

f) Em sua opinião, quais os fatores que poderão contribuir para isso, ou seja, qual poderá ser o poder de ajuda da escola e qual a influência dos fatores externos?

9. Relacionamento escola, família e comunidade

a) Qual o perfil das famílias dos alunos atendidos pela escola?

b) Em sua opinião, qual a influência dessas características familiares nos resultados obtidos pelos alunos?

c) Quais atividades a escola realiza para pais e outros responsáveis?

d) Há algum aspecto da cultura local que a escola tenta resgatar e integrar às suas práticas curriculares? Quais? Como isso é feito?

e) Pode-se afirmar a existência de um clima de colaboração e participação das famílias na escola? Por quais ações concretas? Quais projetos? Quais resultados?

f) A escola realiza ou participa de alguma ação em parceria com a comunidade? Quem as promove? Quais são os objetivos? Existem outras entidades participando dessas ações junto com a escola?

g) Há fatores característicos do entorno comunitário que favorecem ou prejudicam os resultados obtidos na escola? Quais? De que forma esta influência se exerce? 
10. Por fim, dentre os vários fatores que se relacionam aos resultados desta escola, quais são, em sua opinião, os que mais afetam positivamente e os que poderia representar um risco (ou ameaça)?

No final da entrevista agradecer ao entrevistado(a) e gravar também o nome do(a) entrevistador(a). 


\section{PROFESSOR(A)}

\section{Roteiro de Entrevista}

\section{Identificação:}

Nome da Escola

Nome da professora:

No. da turma:

\section{Características do(a) professor(a)}

1. Sexo ( ) masculino ( ) feminino

2. Idade

3. Formação profissional:

e) Se Magistério, especificar ano de conclusão

f) Se Graduação: especificar curso e ano de conclusão

g) Se Pós-Graduação - especificar curso e ano de conclusão

h) Tempo de atividade profissional

i) Tempo na escola

4. Em relação a esta turma:

a) Desde quando está lecionando neste segmento de ensino?

b) Sempre lecionou nesta série?

c) Como você foi alocado(a) nessa turma?

d) Como as turmas foram organizadas, ou seja, a partir de quais critérios foram formadas?

5. Preparo das aulas:

a) Quando prepara suas aulas? Quanto tempo você demorou para preparar a aula de hoje/ontem...? Que material ou outros recursos utilizou para preparar esta aula?

b) Você tem algum tipo de apoio da equipe pedagógica (coordenação, direção ou outros) para planejar ou preparar as aulas?

c) O que você esperava que os alunos aprendessem com essa aula?

d) Você considera que eles aprenderam satisfatoriamente?

e) Quais evidências desse resultado?

f) Sobre a disposição espacial da sala: A organização dos alunos dessa(s) forma(s) foi uma escolha sua ou pode ser considerado um "padrão" da escola? Geralmente, qual a sua preferência? Organização individual ou em grupo? Quando / a partir de quais objetivos você propõe atividade em grupo? Que critérios você usa para organizar os alunos?

9. Infra-estrutura pedagógica, materiais e equipamentos: posse e condições efetivas de uso 
a) Quais os recursos pedagógicos disponíveis para os professores? Como se dá este uso? É regular/esporádico? São suficientes?

b) Nessa escola, como se dá o processo de escolha dos livros didáticos e outros materiais? Esta estratégia de escolha tem tido, em sua opinião, efeito positivo sobre os resultados escolares?

10. Normalmente controla a realização das tarefas pelos alunos? Estas tarefas são sempre corrigidas?

10. Até o final do ano, qual porcentagem das matérias previstas no plano de curso você acredita que cumprirá?

11. Das X horas de aula que você leciona por semana, quantas horas dedica, em média, para cada disciplina?

12. Há alunos que precisariam de algum acompanhamento profissional específico? Se sim, quais os tipos de dificuldades mais comuns?

13. Há perspectiva de reprovação de algum aluno nesta série final de ciclo? Se sim, quantos? (Se a entrevista for no início do ano, a questão deverá ser colocada da seguinte maneira: $\mathrm{Na}$ sua experiência, quantos alunos costumam ser reprovados nessa série/ano escolar?)

14. Quantos alunos dessa turma você acredita que completarão o Ensino Fundamental/Ensino Médio?

15. Nessa escola se estimula o professor a realizar sua prática dentro de algum enfoque metodológico ou abordagem específica de alfabetização ou cada um segue seu próprio método/abordagem? No que consiste este método/abordagem? O que faz a escola para assegurar a realização de práticas pedagógicas dentro desse modelo? A escola verifica as práticas de alfabetização do professor? De que forma?

16. Existem nessa escola orientações pedagógicas, curriculares, disciplinares, de avaliação, etc que devem ser respeitadas e postas em prática por todos os professores? Quais são? Como é feita esta supervisão pela equipe dirigente?

17. Faz parte das atribuições da direção/supervisão entrar em sala para observar o desempenho do professor? Se sim, com qual periodicidade? Como os dados observados são tratados com os professores? Quantas vezes já assistiram à sua aula?

18. A Coordenação estimula o trabalho colaborativo, a troca de experiências entre os pares e a reflexão sobre a própria prática? Se sim, dê exemplos de situações onde isso aconteceu na escola este ano.

19. Como os professores são avaliados em suas práticas? Com base em quais critérios estas avaliações são feitas? Quem tem acesso aos resultados dessas avaliações? Essas avaliações têm repercussão dentro da escola, ou seja, elas contribuem para melhorar as práticas docentes realizadas? Quais professores são avaliados? Só os que estão em estágio probatório ou todos?

20. Neste ano, quais foram as prioridades das reuniões pedagógicas da escola e/ou rede de ensino? Quais ações foram realizadas? Quais estratégias/ recursos foram utilizados? Quais temas foram abordados?

21. Os professores tem acesso aos resultados das avaliações externas (PROALFA/SIMAVE/PROVA BRASIL)? Esses resultados são considerados no planejamento escolar? 
22. Há atividades de formação continuada oferecidas pela escola ou pela rede de ensino? Existe obrigatoriedade na participação ou e facultativo? Quais os temas tratados nessas atividades?

No final da entrevista agradecer ao entrevistado(a) e gravar também o nome do(a) entrevistador(a). 